UNIVERSIDADE DE SÃO PAULO

INSTITUTO DE GEOCIÊNCIAS

\title{
COMPOSIÇÃO ISOTÓPICA E IDADE DAS MINERALIZAÇÕES DE Au EPITERMAL DO DISTRITO MINEIRO DE MARMATO, NOROESTE DA COLÔMBIA
}

\section{FABIO HUMBERTO DÍAZ PINZÓN}

Orientador: Prof. Dr. Colombo Celso Gaeta Tassinari

DISSERTAÇÃO DE MESTRADO

COMISSÃO JULGADORA

Nome

Presidente: Prof. Dr. Colombo Celso Gaeta Tassinari

Examinadores: Prof. Dr. Márcio Martins Pimentel

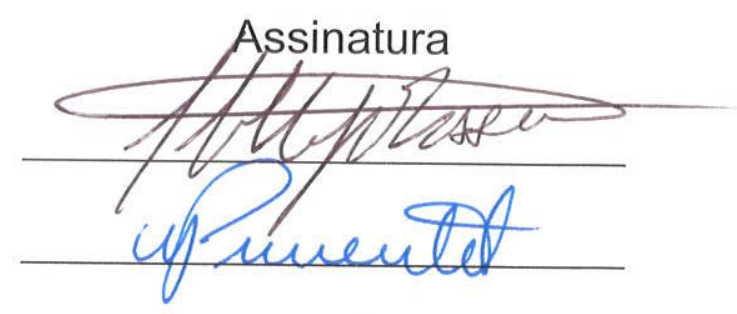

Profa. Dra. Marly Babinski

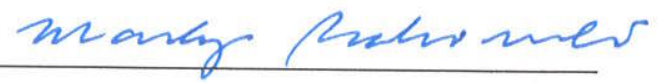

SÃO PAULO

2002 


\section{UNIVERSIDADE DE SÃO PAULO \\ INSTITUTO DE GEOCIÊNCIAS}

COMPOSIÇÃO ISOTÓPICA E IDADE DAS MINERALIZAÇÕES DE Au EPITERMAL DO DISTRITO MINEIRO DE MARMATO, NOROESTE DA COLÔMBIA

Fabio Humberto Díaz Pinzón

Orientador: Prof. Dr. Colombo Celso Gaeta Tassinari

DISSERTAÇÃO DE MESTRADO

Programa de Pós-Graduação em Recursos Minerais e Hidrogeologia

SÃO PAULO

2002

DEDALUS - Acervo - IGC

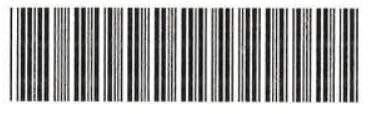

30900011580 
A mi hijo Santiago, sonrisa de la vida

A mis Padres Jairo y Beatriz, mi farol en la niebla A Liliana, compañera de barco en Brasil 


\section{AGRADECIMENTOS}

Expresso meus agradecimentos as pessoas e entidades que contribuíram para a realização deste trabalho.

Principalmente a meu orientador Prof. Dr. Colombo Celso Gaeta Tassinari, por permitir-me estudar neste maravilhoso País, e pelo seu constante apoio e conselho oportuno no desenvolvimento deste Mestrado, sem esquecer as inumeráveis correções de portuñol.

À FAPESP pela bolsa de Mestrado outorgada, processo 99/11841-7.

À Pró-Reitoria de Pós-Graduação pelos três meses de bolsa outorgados.

Ao Instituto de Geociências da Universidade de São Paulo, pela formação acadêmica durante o Mestrado.

Aos Professores do Centro de Pesquisas Geocronológicas (CPGeo), em especial aos professores Umberto Cordani, Marly Babinsky, Oswaldo Siga Jr. e Kei Sato.

À Professora Gianna Garda, pela colaboração na descrição inicial das seções polidas.

Ao Grupo do Centro de Pesquisas Geocronológicas, Helen, Ivone, Mitzi, Sato, Vasco, Vera, Veridiana e em especial a Izabel, Solange, Artur e Liliane, pela grande colaboração e amizade.

Ao Laboratório de Caracterização Tecnológica da Escola Politécnica, e no Instituto de Geociências ao Isaac, pela amabilidade e ajuda nas análises no MEV.

Aos Amigos de INGEOMINAS, pela colaboração oferecida e as amostras emprestadas.

Ao Geólogo Cesar Javier Vinasco Vallejo pelas amostras emprestadas.

À Secretaria de Pós -Graduação do IGc-USP, Ana Paula e Magali, pela colaboração e amizade.

À Márcia Mika Saito, por sua colaboração e amizade.

Ao Agustín pelas discussões geológicas e sua amizade.

Aos meus colegas e amigos, Erika, Alejandro, Marcela, Agustín, Michelle, Cesar, Andrés, Diana, Javier, Anabel, Paul e Cintia por sua amizade.

Aos meus Pais, Jairo e Beatriz, pelo apoio irrestrito e aos meus irmãos Jairo, Lida, Beatriz Helena pelas palavras de ânimo.

À Liliana pelo carinho, companhia, dedicação e ajuda durante este tempo, e ao meu filho Santiago por ser o meu incentivo.

E a todos aqueles que contribuíram de forma direta ou indireta para a realização deste Mestrado, meu muito obrigado. 


\section{SUMÁRIO}

INDICE DE FIGURAS

INDICE DE TABELAS

RESUMO

ABSTRACT

1. INTRODUÇÃO

1.1. OBJETIVOS DO PROJETO

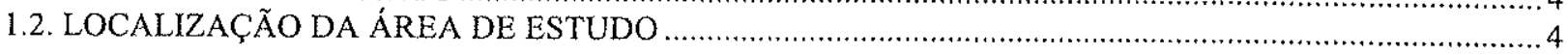

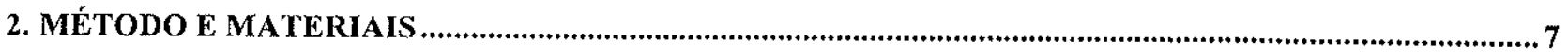

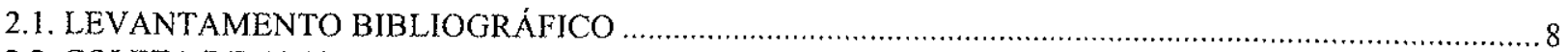

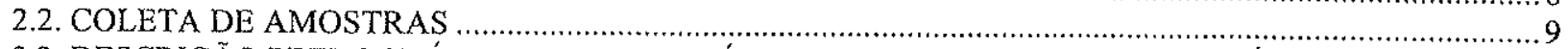

2.3. DESCRIÇÃO PETROGRÁFICA E MINERALÓGICA DAS AMOSTRAS PARA ANÁLISES ISOTÓPICAS.

2.4 PREPARAÇÃO DAS AMOSTRAS PARA ANALISES ISOTÓPICAS $\ldots$

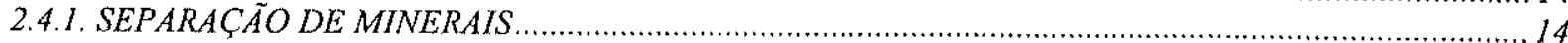

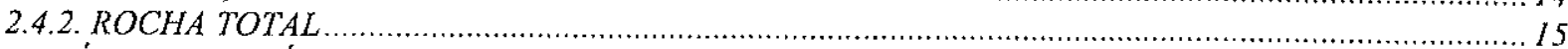

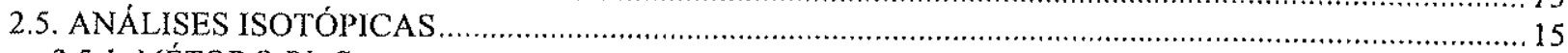

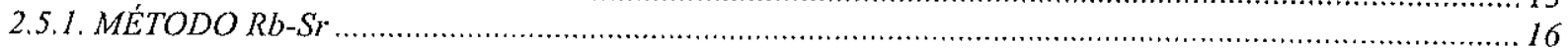

2.5.1.1. Técnica de Lixiviaçâo em Esfalerita......................................................................................................16

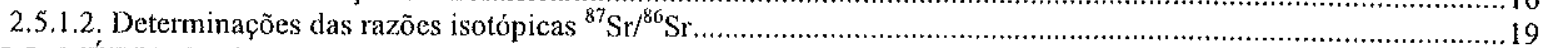

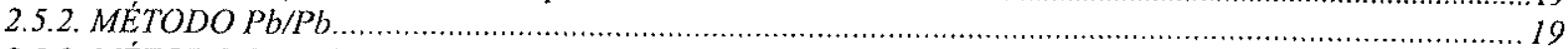

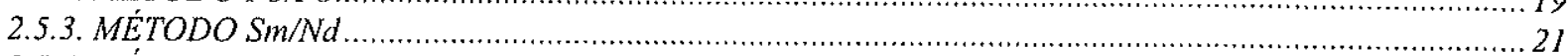

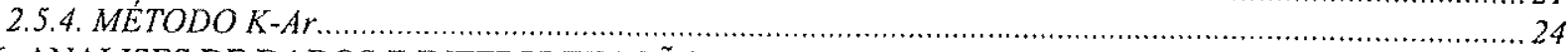

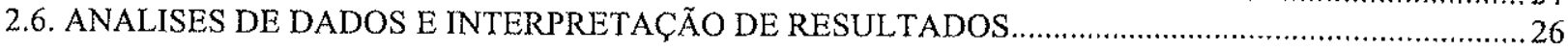

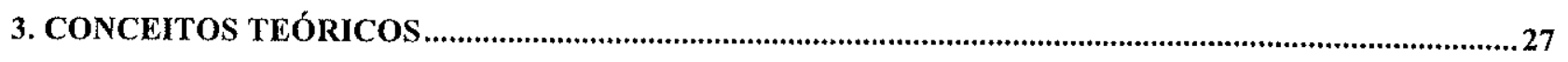

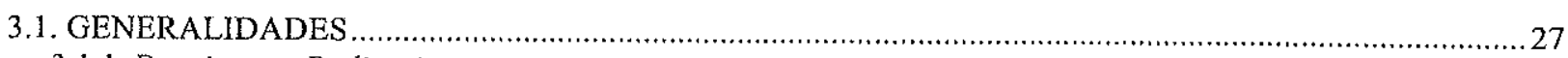

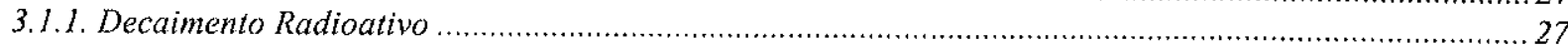

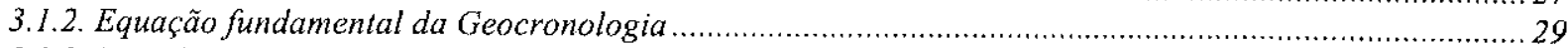

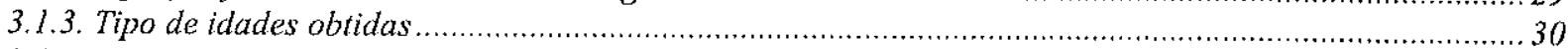

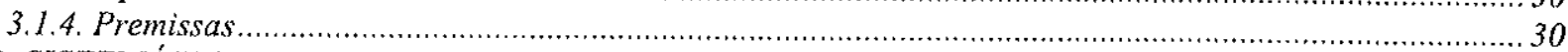

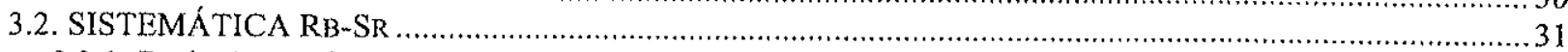

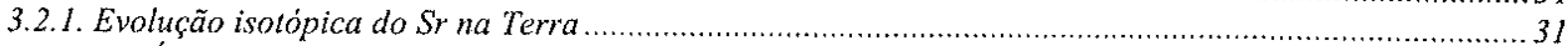

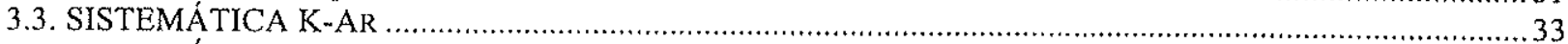

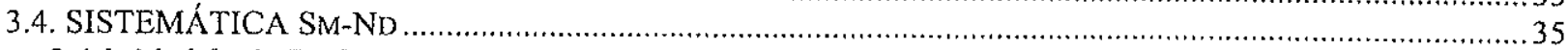

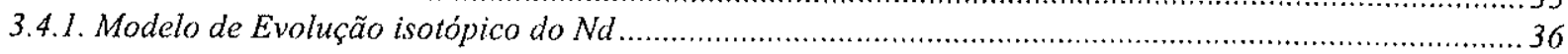

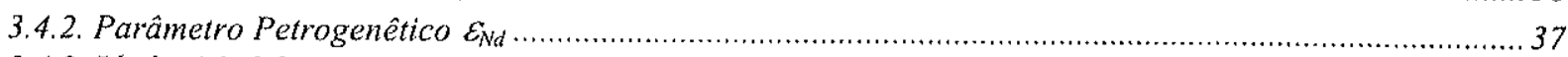

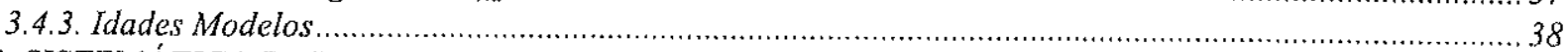

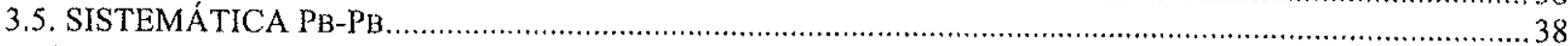

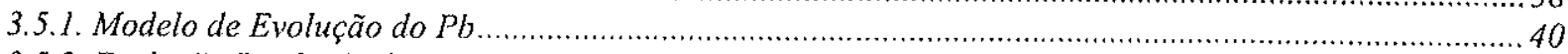

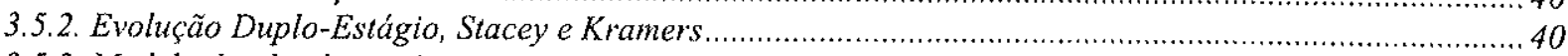

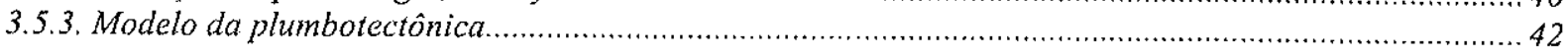

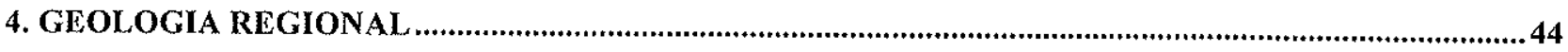

4.1. CONTEXTO TECTÔNICO …….................................................................................................. 44

4.2. GEOLOGIA DA ÁREA DE MARMATO

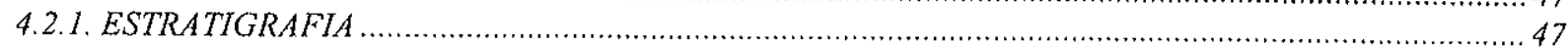

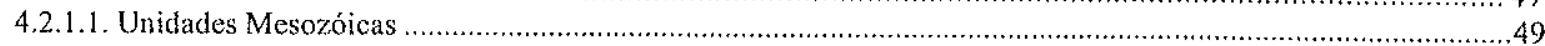

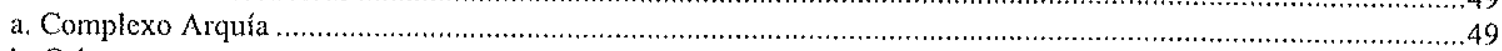

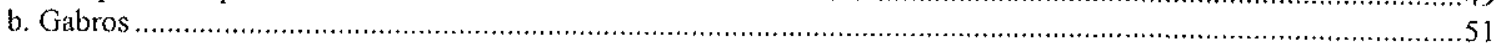




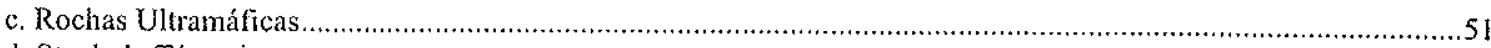

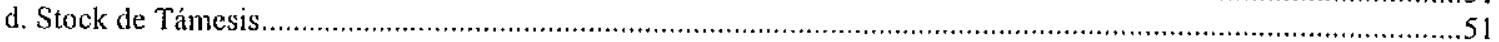

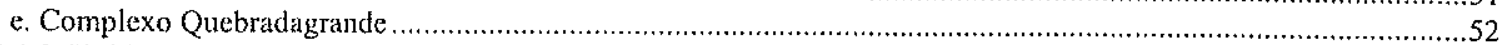

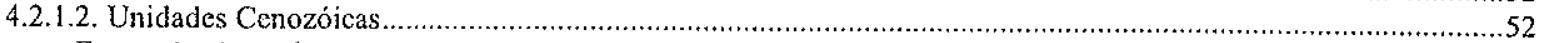

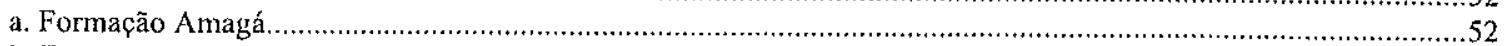

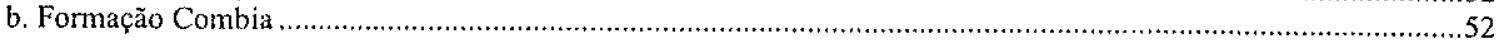

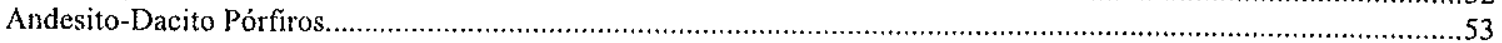

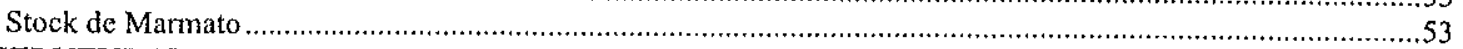

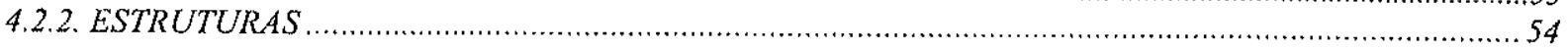

5. GEOLOGIA DE MARMATO E MINERALIZAÇÕES AURÍFERAS .......................................................55

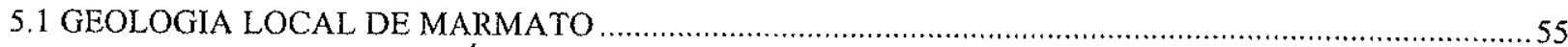

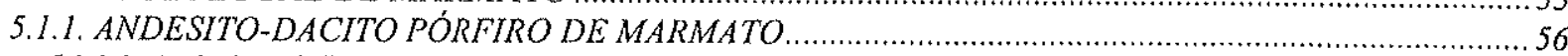

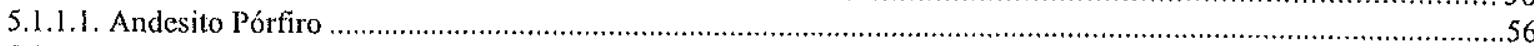

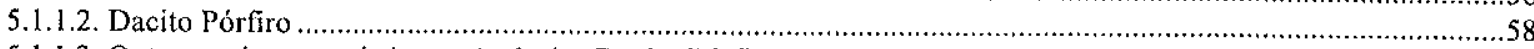

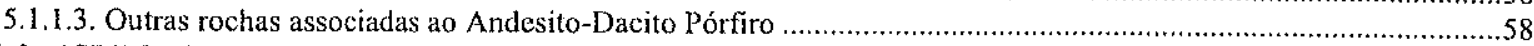

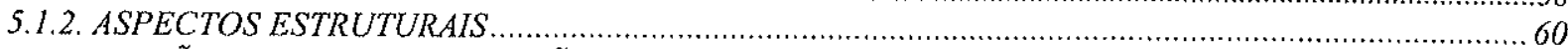

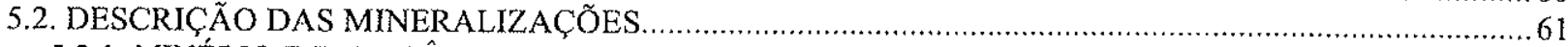

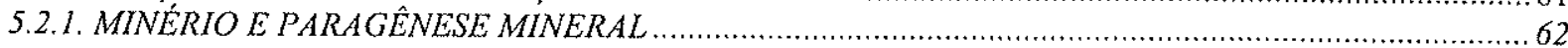

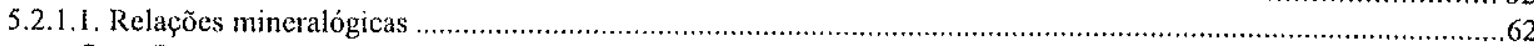

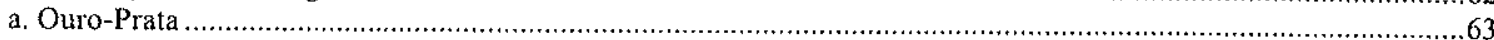

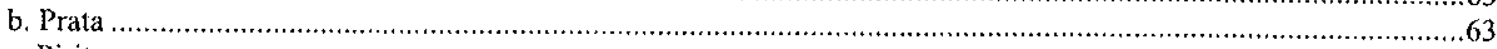

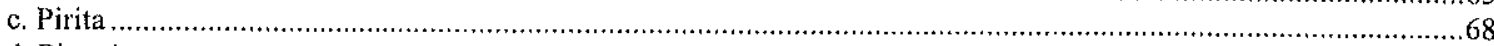

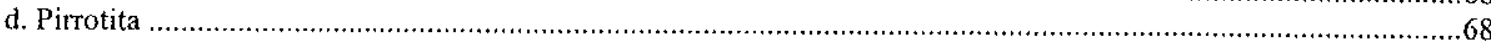

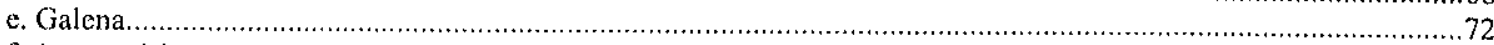

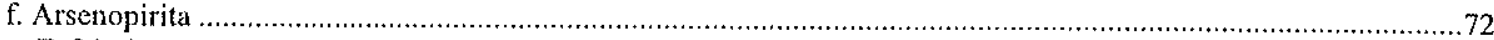

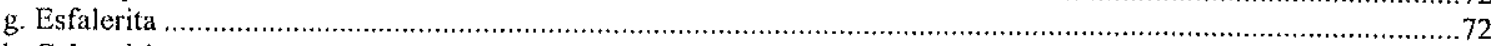

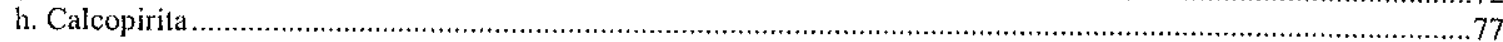

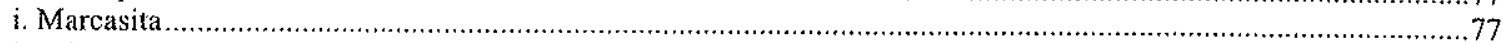

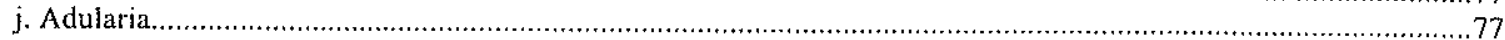

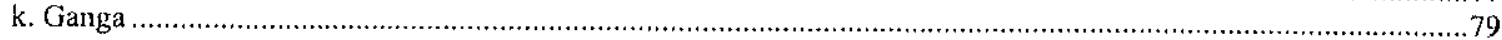

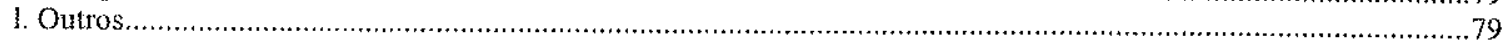

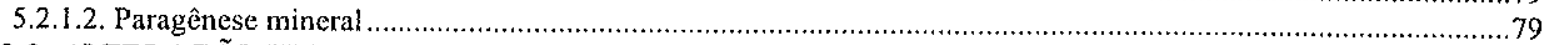

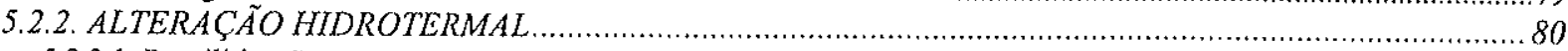

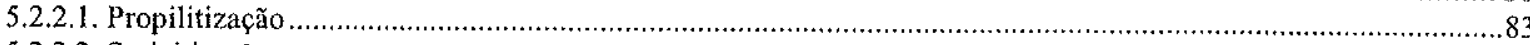

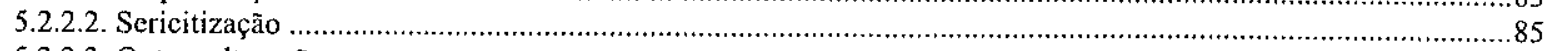

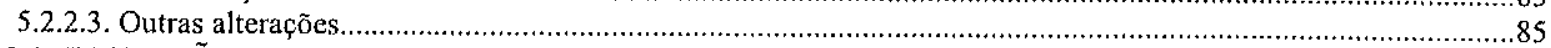

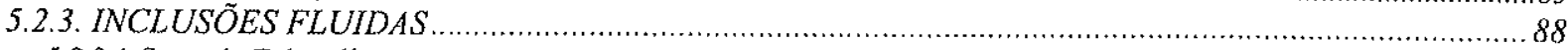

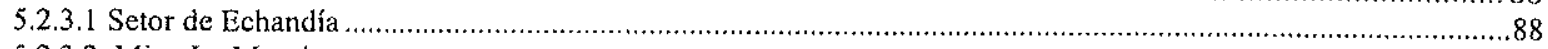

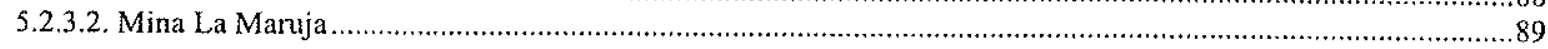

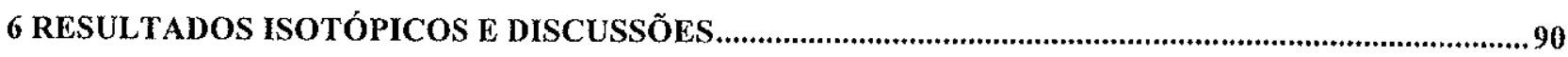

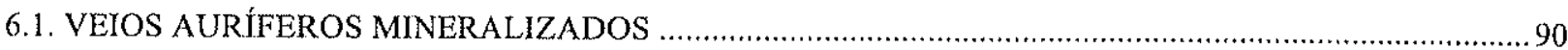

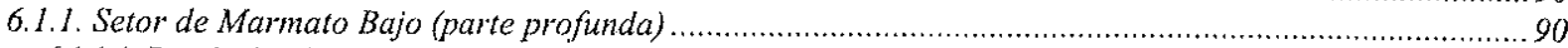

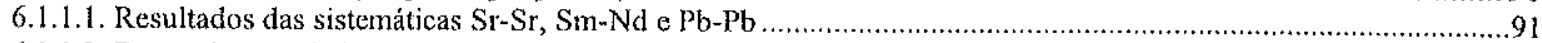

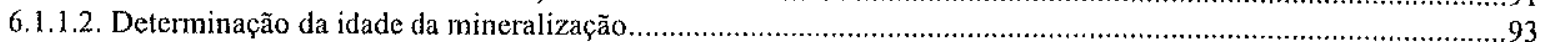

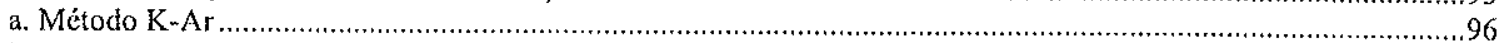

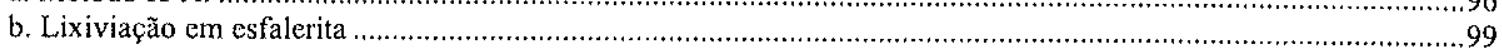

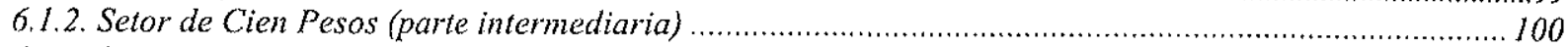

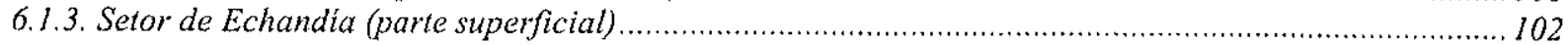

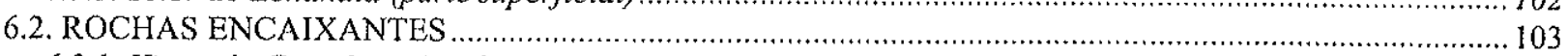

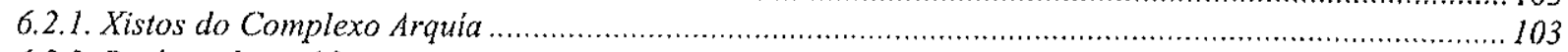

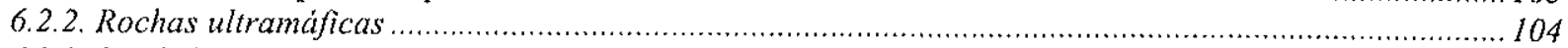

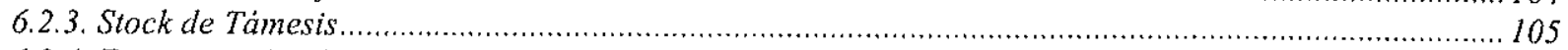

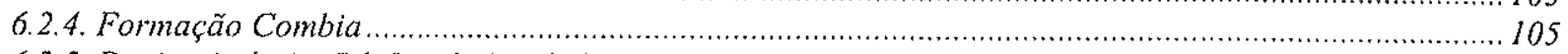

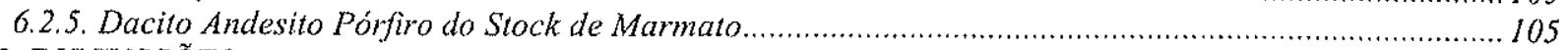

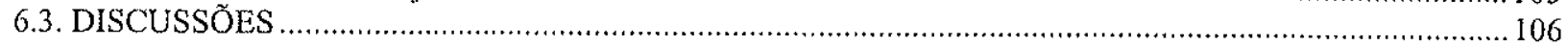

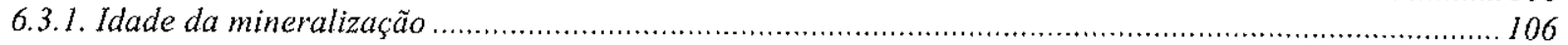

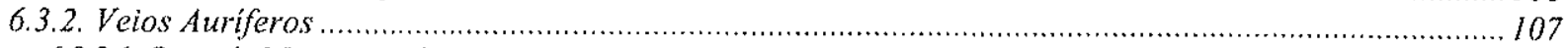

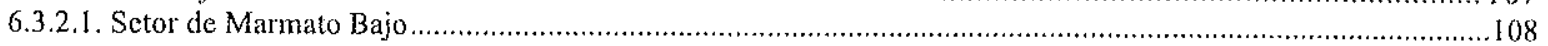


6.3.2.2. Setor de Cien Pesos

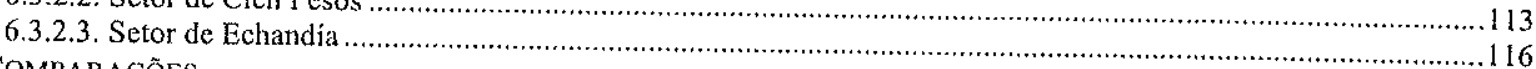

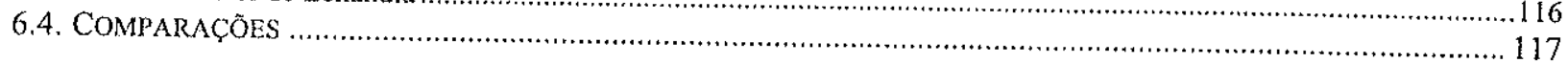

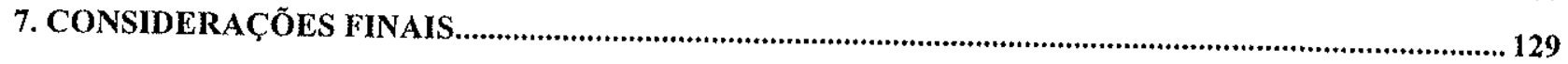

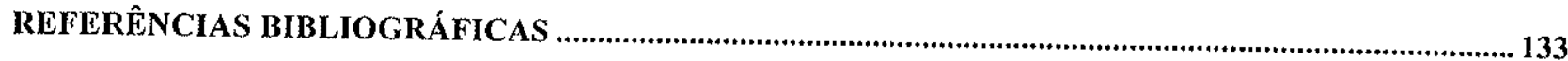




\section{ÍNDICE DE FIGURAS}

Figura 1. Localização da Área de Estudo.

Figura 2. Atividades desenvolvidas no projeto de Pesquisa .......................................................................... 7

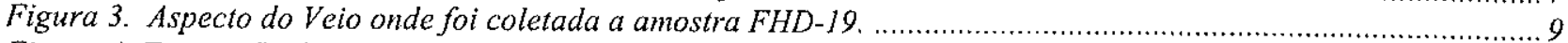

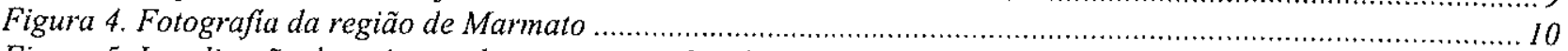

Figura 5. Localização das minas e das amostras coletadas ..........................................................................

Figura 6. Lixiviação em esfalerita, procedimento adotado no CPGeo............................................................. 18

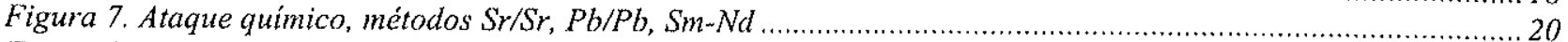

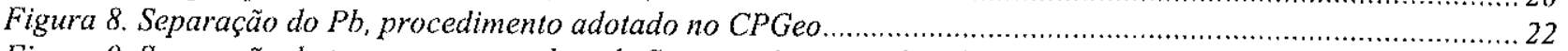

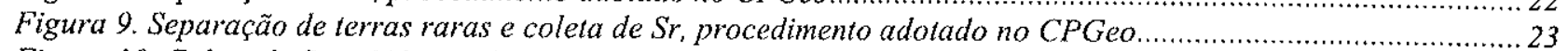

Figura 10. Coleta de Sm e Nd na coluna de teflón, procedimento adotado no CPGeo .............................................23

Figura 11. Procedimento adotado no CPGeo, no ataque quimico e leitura do Potássio no fotômetro.........................25

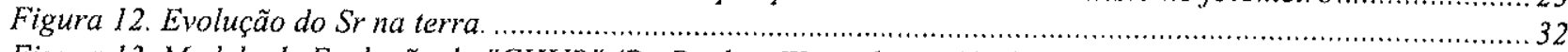

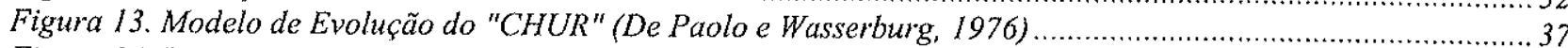

Figura 14. Diagrama de evolução isotópica do Pb em estágio duplo de Stacey e Kramers (1975) ............................... 41

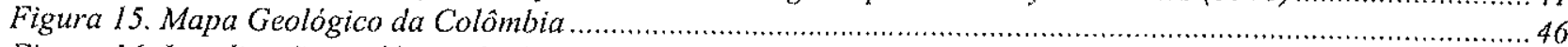

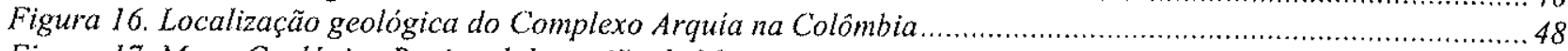

Figura 17. Mapa Geológico Regional da regiäo de Marmato........................................................................... 50

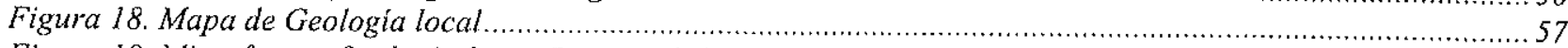

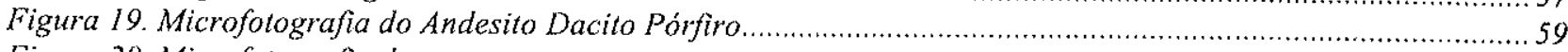

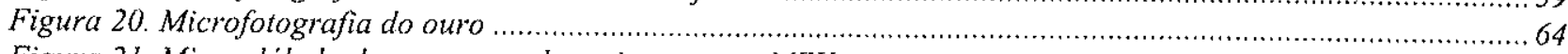

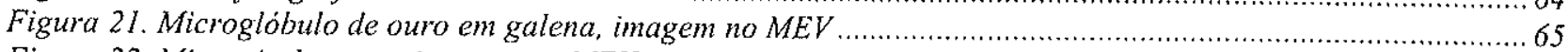

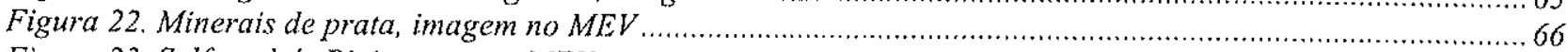

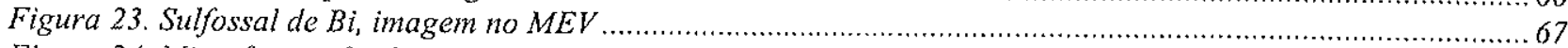

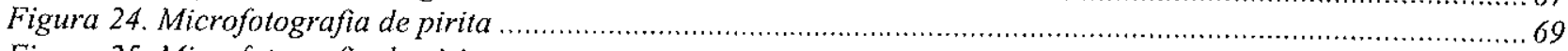

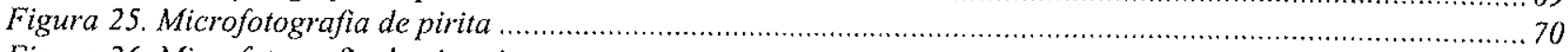

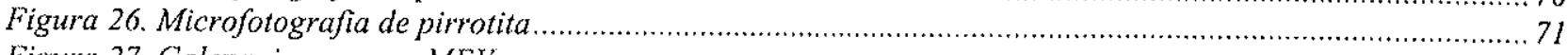

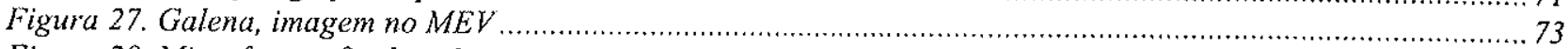

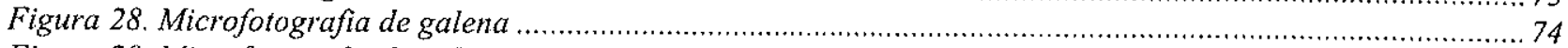

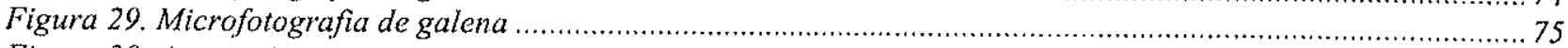

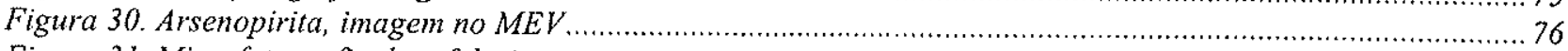

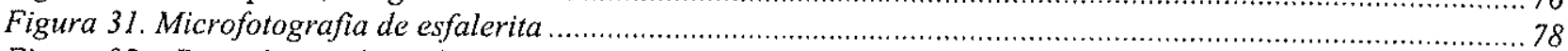

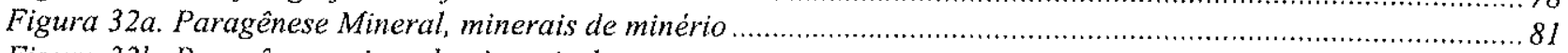

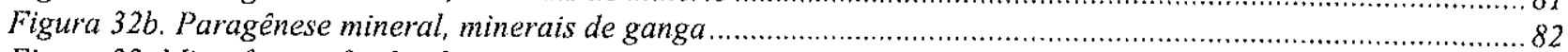

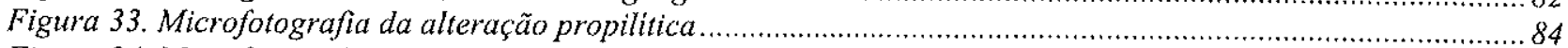

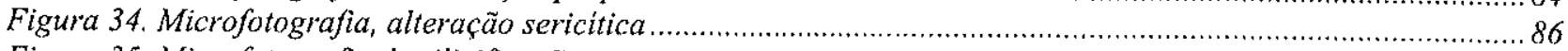

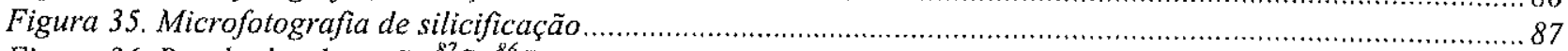

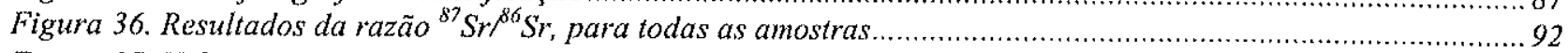

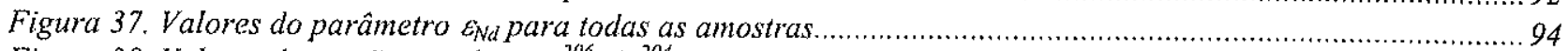

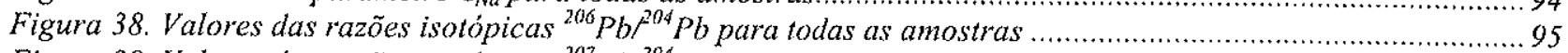

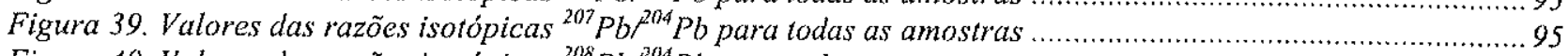

Figura 40. Valores das razões isotópicas ${ }^{208} \mathrm{~Pb}{ }^{204} \mathrm{~Pb}$ para todas as amostras ..................................................... 95

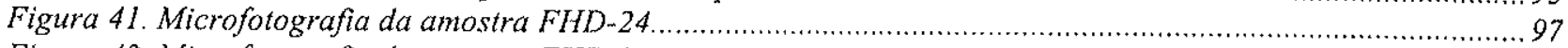

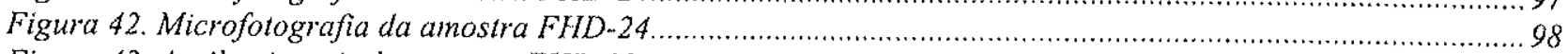

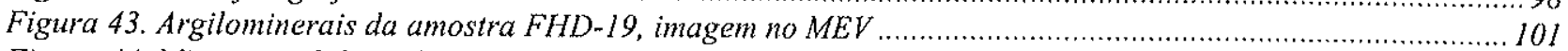

Figura 44. Microcristal de carbonato dentro de esfalerita (FHD-19), imagem no MEV............................................... 101

Figura 45. Diagrama ${ }^{87} \mathrm{Sr}^{86} \mathrm{Sr}_{(0)} x \mathcal{E}_{\mathrm{Nd}(0),}$, para as piritas e as rochas encaixantes............................................. I09

Figura 46. Diagrama Uranogênico, dos sulfetos e das rochas encaixantes .......................................................... 110

Figura 47. Diagrama Thoriogênico dos sulfetos e das rochas encaixantes ........................................................ 111

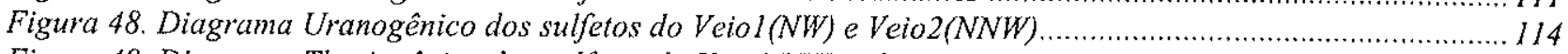

Figura 49. Diagrama Thoriogênico dos sulfetos do Veiol(NW) e do Veio2(NNW) .................................................115

Figura 50. Diagrama ${ }^{87} S_{r}^{86} S r x \varepsilon_{N d}$ do Stock de Marmato e os Vulcões Galeras e Ruíz. ......................................118 
Figura 51. Comparação no diagrama Uranogênico das amostras do Marmato, depósitos tipo pórfiro da Colômbia e os Vulcões Galeras e Ruiz.

Figura 52. Comparação no diagrama Thoriogênico das amostras do Marmato, depósitos tipo pórfiro da Colômbia e os Vulcões Galeras e Ruiz.

Figura 53. Localização Geotectónica dos depósitos do Equador estudados por Chiaradia e Fonboté (200Ib)...... 122

Figura 54. Comparação no diagrama Uranogenico, dos valores isotópicos de Marmato e valores de depósitos tipo

VHMS do Equador.

Figura 55. Comparação no diagrama Thoriogênico, dos valores isotópicos de Marmato e valores de depósitos tipo VHMS do Equador.

Figura 56. Comparação no diagrama Uranogênico, dos valores isotópicos de Marmato e valores de depósitos tipo pórfiro e epitermal do Equador

Figura 57. Comparação no diagrama Thoriogênico, dos valores isotópicos de Marmato e valores de depósitos tipo pórfiro e epitermal do Equador

Figura 58. Sintese da Evolução tectónica e metalogenêtica

Figura 59. Diagrama da evolução tectónica, 22Ma-Hoje. 


\section{INDICE DE TABELAS}

Tabela 1. Relação de amostras coletadas e analises realizadas 12

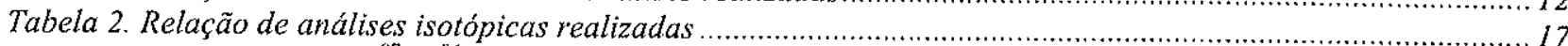

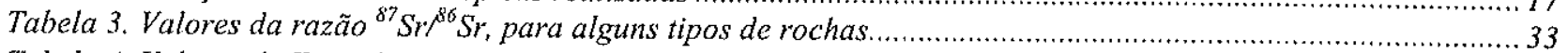

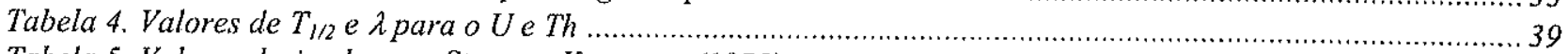

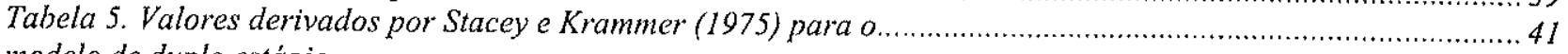

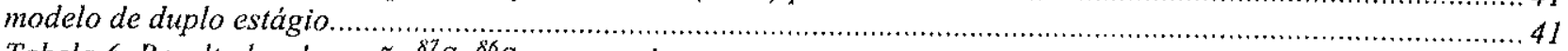

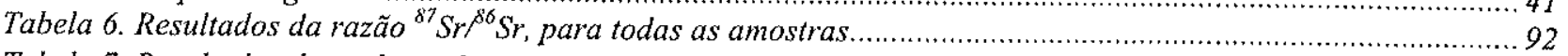

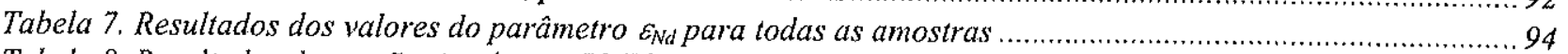

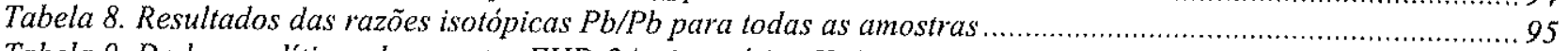

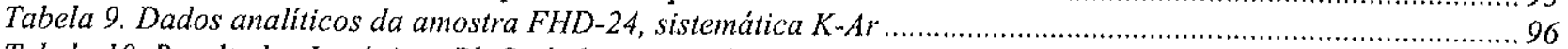

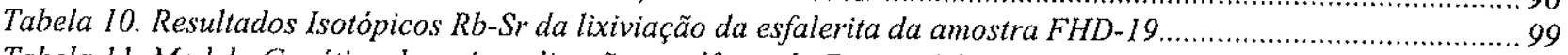

Tabela 11. Modelo Genético das mineralizações aurf́feras do Distrito Mineiro de Marmato ......................................... 132 


\section{RESUMO}

No Distrito Mineiro (Au-Ag) de Marmato, localizado nos Andes setentrionais da Colômbia, foi realizado um estudo de isótopos radiogênicos para caracterizar isotópicamente a mineralização visando obter informação sobre as possíveis rochas fontes dos fluidos hidrotermais; assim como para determinar tentativamente a idade das mineralizações.

Para a caracterização isotópica e a discussão dos dados, a mineralização epitermal de ouro foi dividida em três níveis: na parte superficial, o denominado setor de Echandia, na parte intermediaria (setor de Cien Pesos) e na parte profunda (setor de Marmato bajo). Nos minerais de mineiro e de ganga (pirita, esfalerita, galena, carbonato), foram realizados em total, 9 análises $\mathrm{Sr} / \mathrm{Sr}, 7$ análises $\mathrm{Sm} / \mathrm{Nd}$ e 10 análises $\mathrm{Pb} / \mathrm{Pb}$. Nas rochas encaixantes realizaram-se 11 análises $\mathrm{Sr} / \mathrm{Sr}$ em rocha (RT), 10 análises $\mathrm{Sm} / \mathrm{Nd}$ e $1 \mathrm{Nd} / \mathrm{Nd}$ em $\mathrm{RT}$ e 7 análises $\mathrm{Pb} / \mathrm{Pb}$ em $\mathrm{RT}$. Na determinação da idade das mineralizaçöes foi utilizado o método $\mathrm{Rb}-\mathrm{Sr}$ em lixiviados de esfalerita, e também uma datação K-Ar em plagioclásio sericitizado.

As amostras foram analisadas nos laboratórios do Centro de Pesquisa Geocronológicas da Universidade de São Paulo (CPGeo). Os minerais foram separados utilizando os métodos tradicionais, separador magnético (Frantz Isodynamic), meio denso (lodeto de Metileno e Bromoformo), sendo purificadas por catação manual com auxilio de lupa binocular; as amostras de RT foram moídas em moinho de bolas com cápsulas revestidas em carbeto de tungstênio. $O$ ataque químico foi realizado com diferentes ácidos, nas sistemáticas $\mathrm{Sr} / \mathrm{Sr}$ e $\mathrm{Sm} / \mathrm{Nd}$ com $\mathrm{HCl}, \mathrm{HNO}_{3}$ e $\mathrm{HF}$; no caso do $\mathrm{Pb} / \mathrm{Pb}$ com $\mathrm{HCl}, \mathrm{HNO}_{3}, \mathrm{HF}$ e $\mathrm{HBr}$; para $\mathrm{K}-\mathrm{Ar}$ com $\mathrm{H}_{2} \mathrm{SO}_{4}, \mathrm{HF}, \mathrm{HNO}_{3}, \mathrm{NH}_{4} \mathrm{OH}$ e $\left(\mathrm{NH}_{4}\right) 2 \mathrm{CO}_{3}$. A separação de elementos foi realizada em colunas de troca iônicas: no $\mathrm{Sr} / \mathrm{Sr}$ foi usada a coluna de resina catiônica (AG WX8, 200-400 mesh); no Sm/Nd a coluna primaria preenchida com resina catiônica (AG 50W X8, 200-400 mesh) e a coluna preenchida com pó de teflon (200 mesh); no $\mathrm{Pb} / \mathrm{Pb}$ uma coluna de troca iônica (AG 1-X8 200-400, mesh chloride form Bio-Rad). As análises foram realizadas utilizando o espectrômetro VG 354, monocoletor, o espectrômetro VG 354, multicoletor, 
o espectrômetro tipo Mass Spectrometer Model 262, multicoletor; e para K-Ar um espectrômetro de tipo MS-1, com fonte iônica tipo "NIER".

Para a seleção das amostras para análises isotópicas e suas interpretações, foi realizada uma descrição petrográfica e mineralógica das amostras, em total fizeram-se, 15 descrições petrográficas de seções delgadas, 11 de polidos e 7 no Microscópio Eletrônico de Varredura (MEV).

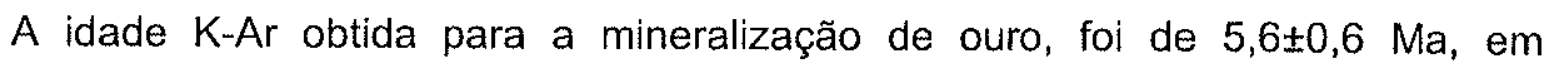
plagioclásio sericítizado do Dacito Pórfiro alterado hidrotermalmente. Esta idade é concordante com a idade da última reativação do Sistema de Falhas de CaucaRomeral, 5,6 $\pm 0,4 \mathrm{Ma}$, Ar-Ar em biotita (Vinasco, 2001), e um pouco mais jovem do que

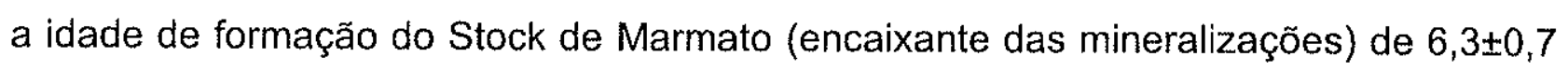
Ma, K-Ar em horblénda (Restrepo et al., 1981); indicando uma duração aproximada do sistema hidrotermal de 700.000 anos. A idade também permite relacionar à mineralização com um ambiente tectônico de tipo distensional, originado por bacias de tipo "pull apart" formadas na depressão do Cauca-Patía, pela reativação com movimento sinistral do Sistema de Falhas de Cauca Romeral originada pela acreção do arco Panamá Choco à borda NW de Sul América no Mioceno.

Nos andesitos dacitos pórfiros encaixantes dos veios, obtiveram-se razões de ${ }^{87} \mathrm{Sr} /{ }^{86} \mathrm{Sr}$ entre 0,70444 e 0,70460 e do parâmetro $\varepsilon_{\mathrm{Nd}}$ entre $+2,2$ e $+3,2$; indicando magmas pouco diferenciados, interpretados como derivados do magmatismo associado à subducção da placa de Nazca no continente Sul Américano, sendo sua ascensão de forma rápida e controlada pelo Sistema de Falhas de Romeral. Nos sulfetos as razões ${ }^{87} \mathrm{Sr} /{ }^{86} \mathrm{Sr}$ estão entre 0,70500 e 0,71210 e o parâmetro $\varepsilon_{\mathrm{Nd}}$ entre $-1,11$ e $+2,40$ para a parte superficial e intermediária, e de $+1,95$ e $+3,28$ na parte mais profunda. No setor superficial, os resultados estão indicando uma participação importante das encaixantes, na circulação de fluidos hidrotermais meteóricos; já no setor de Marmato Bajo, o aporte das rochas porfiríticas é maior, e os fluidos parecem ser uma mistura de fluidos hidrotermal meteórico e hidrotermal magmático. Os valores isotópicos das razões ${ }^{206} \mathrm{~Pb} /{ }^{204} \mathrm{~Pb},{ }^{207} \mathrm{~Pb} /{ }^{204} \mathrm{~Pb}$ e ${ }^{208} \mathrm{~Pb} /{ }^{204} \mathrm{~Pb}$, variaram entre $18,970-19,258,15,605-15,910$ e 38,813-39,751 respectivamente. Os resultados indicam a derivação do $\mathrm{Pb}$ dos sulfetos, 
das rochas encaixantes, principalmente do Dacito Andesito Pórfiro, com uma contribuição menor do xisto grafitoso do Complexo Arquía. 


\section{ABSTRACT}

A radiogenic isotopic study was carried out on the Au-Ag Marmato mining district in the setentrional Andes of Colombia in order to characterize the age and the sources of the mineralization.

To isotopic characterization and data discussion, the epithermal gold mineralization were divided in three different levels: the first one near surface is named Echandia, the intermediary (Cien Pesos sector) and the deepest (Marmato Bajo). In the ore and gangue minerals (pyrite, sphalerite, galena and carbonate) where done $9 \mathrm{Sr} / \mathrm{Sr}$ analyses, $7 \mathrm{Sm} / \mathrm{Nd}$ and $10 \mathrm{~Pb} / \mathrm{Pb}$ analyses. In the host rocks where done $11 \mathrm{Sr} / \mathrm{Sr}, 10$ $\mathrm{Sm} / \mathrm{Nd}, 1 \mathrm{Nd} / \mathrm{Nd}$, and $7 \mathrm{~Pb} / \mathrm{Pb}$ whole rock analyses.

All the samples where analyzed at the Geochronological Research Center of the São Paulo University (CPGeo). Minerals were separated by conventional methods using magnetic separation and heavy liquids, and finally they were hand picked with the aid of a binocular lens. Whole rock samples were crushed and milled in a tungsten mill. The chemical attack was done with $\mathrm{HCl}, \mathrm{HNO}_{3}$ and $\mathrm{HF}$ for $\mathrm{Sr} / \mathrm{Sr}$ and $\mathrm{Sm} / \mathrm{Nd}, \mathrm{HCl}, \mathrm{HNO}_{3}, \mathrm{HF}$ and $\mathrm{HBr}$ for the $\mathrm{Pb} / \mathrm{Pb}$, and $\mathrm{H}_{2} \mathrm{SO}_{4}, \mathrm{HF}, \mathrm{HNO}_{3}, \mathrm{NH}_{4} \mathrm{OH}$ and $\left(\mathrm{NH}_{4}\right) 2 \mathrm{CO}_{3}$ for the $\mathrm{K}-\mathrm{Ar}$ analyses. Element separation where done on the resin columns AG WX8 (200-400 mesh) for Sr/Sr, the AG 50W X8 (200-400 mesh) and the Teflon powder column for $\mathrm{Sm} / \mathrm{Nd}$, and the $\mathrm{Pb} / \mathrm{Pb}$ was done on the $\mathrm{AG} 1-\mathrm{X8}$ (200-400 mesh). Isotopic analyses were carried on the Mass Spectrometer VG-354 monocollector, VG 354 multicollector, and Finnigan 262 multicollector. The $\mathrm{K}-\mathrm{Ar}$ analyses were done in the MS-1 Spectrometer with ionic supply "NIER".

The sample selection for isotopic analyses were made based on petrographic and mineralogical characteristics, that includes 15 thin sections, 11 polished sections, and 7 analized sections on the back scatter electron microscope.

An $\mathrm{K}$-Ar age determination of $5.6 \pm 0.6 \mathrm{Ma}$, obtained on sericitized plagioclase from hydrothermal alterated host rocks, is considered as the timming of the gold mineralization. This age is in agreement with the Cauca-Romeral Fault System reactivation, which developed at 5.6 $\pm 0.4 \mathrm{Ma}$ (Ar-Ar on biotite), and it is slightly younger than the cooling age, $6.3 \pm 0.7 \mathrm{Ma}$ (K-Ar on hornblend), of the Marmato stock. These 
geochronological data suggest that the hydrothermal system was active for 700.000 years approximately. The mineralization is related to distensional tectonic environment, that allows the left re-activation of the Cauca-Romeral Fault System, and the formation of pull-apart basins in the Cauca-Patia depression, in relation with the accretion of the Panama-Arc on the NW margin of South America.

The host andesitic-dacitic porphyric rocks have ${ }^{87} \mathrm{Sr} / \mathrm{Sr}^{86}$ ratios between 0.7044 and 0.70460 and $\varepsilon_{\mathrm{Nd}}+2.2$ and +3.2 that suggest a poorly differentiated magma, formed by the subduction of the Nazca Plate on the South American Continent, and its emplacement was controlled by the Cauca-Romeral Fault System. The ${ }^{87} \mathrm{Sr} / \mathrm{Sr}^{86}$ values of sulphides, range from 0.70500 and 0.71210 and $\varepsilon_{N d}$ from -1.11 and +2.40 , for the shallow and intermediary level, while for the deep sector the $\varepsilon_{\mathrm{Nd}}$ values are from +3.28 to +1.25 . These results indicates that the shallow level was characterized by a more significant participation of the host rocks in the meteoric hydrothermal fluids, in contrast the porphyric rocks are more important sources for the deeper levels, where the fluid seems to be a mix of meteoric and magmatic waters. $\mathrm{Pb}$ isotope values from sulphides range for ${ }^{206} \mathrm{~Pb},{ }^{207} \mathrm{~Pb}$ and ${ }^{208} \mathrm{~Pb}$ from $18.970-19.258,15.605-15.910,38.813-39.751$ respectively. The data indicate derivation of the ore leads from country rocks, mainly from the Marmato stock, with a minor contribution of graphite schists, of the Arquía metamorphic complex. 


\section{INTRODUÇĀO}

Os Andes Colombianos são formados por três cadeias montanhosas que percorrem o Pais com direção aproximada Sul-Norte: Cordilheiras Oriental, Central e Ocidental. Do ponto de vista Geológico são divididos pelo Sistema de Falhas de CaucaRomeral (SFCR) em dois domínios geológicos diferentes: o primeiro a leste do SFCR, constituído pelas Cordilheiras Oriental e Central, é de afinidade siálica com embasamento precambriano e paleozóico; a Cordilheira Central é intrudida por batólitos mesozóicos e cenozóicos, e a Oriental é coberta por seqüências sedimentares paleozóicas e mesozóicas e isoladamente cenozóicas que foram deformadas e afetadas por tectonismo durante o Cenozóico, originando o levantamento da Cordilheira Oriental (Cooper et al., 1995; Taboada, 2000); Esse domínio foi originado pela acreção sucessiva de terrenos até o Paleozóico inferior (Etayo et al., 1986) ou desde o Paleozóico superior até o Cretácico superior (Toussaint e Restrepo, 1989); sendo posteriormente afetado por rifteamento no Pérmiano ou Triásico (Etayo et al., 1986). A oeste do SFCR, encontra-se um segundo domínio que constituí a Cordilheira Ocidental, o qual foi formado pela acreção sucessiva de terrenos alóctones de afinidade simática no Mesozóico e Cenozóico, sendo coberto por rochas sedimentares no Cenozóico (Aspden et al., 1987; Etayo et al., 1986; Restrepo e Toussaint, 1988).

A acreção do arco Panamá-Choco à Cordilheira Ocidental no Mioceno médio (Duque-Caro, 1990), originou a reativação com movimento sinistral do Sistema de Falhas de Cauca-Romeral na região norte (Paris e Romero, 1994; Ego et al., 1995); os movimentos transcorrentes originaram bacias do tipo "pull apart" ocasionando o adelgaçamento do embasamento, permitindo desta forma a intrusão dos corpos subvulcânicos da Formação Combia (Ordoñez, 2001). O Stock de Marmato, encaixante da mineralização em estudo, pertence à Formação Combia e foi formado no Mioceno tardio (Restrepo et al., 1981).

No Distrito Mineiro de Marmato a atividade mineira está concentrada em quatro setores: Marmato, Echandia, Cien Pesos e Marmato bajo. O setor de Echandía tem altitudes entre 1450 e $1600 \mathrm{~m}$, o setor de Cien Pesos entre 1450 e $1300 \mathrm{~m}$, e o setor de Marmato bajo entre 1160 e $1260 \mathrm{~m}$; tendo diferença de $400 \mathrm{~m}$ entre os diferentes niveis 
no sistema hidrotermal. O Distrito tem sido objeto de vários estudos que definiram os tipos de alterações hidrotermais, a mineralogia e paragênese mineral, assim como os aspectos geológicos e estruturais. No setor de Echandía, os principais estudos são: Rossetti et al. (1999), Buenaventura (1997), López Rendón (1991), López Rendón e Bedoya (1989), Alvarez (1989) e Monsalve (1989); no setor de Cien Pesos: Medina (1989) e Restrepo (1989); no setor de Marmato bajo: Bedoya (1998) e Cadavid e Escovar (1991). Em destaque os estudos de Rossetti et al. (1999) no setor de Echandía e de Bedoya (1998) no setor de Marmato Bajo, os quais foram mais detalhados e incluíram estudos de inclusões fluidas, permitindo-thes propor temperaturas de formação dos veios e salinidade dos fluidos envolvidos.

No Distrito de Marmato as mineralizações são de tipo adularia sericita ou baixa sulfetação (Rossetti et al., 1999; Buenaventura, 1997). As alterações hidrotermais dominantes são: ampla propilitização e restrita sericitização (1 até $2 \mathrm{~m}$ ). Os veios são distensionais sub-verticais com espessura de até $2 \mathrm{~m}$ e comprimento até de $250 \mathrm{~m}$, estão preenchidos por pirita e esfalerita, e em menor quantidade de calcopirita, galena, arsenopirita, pirrotita, marcasita e mais raramente "polybasite", argentita, ouro, electrum (Au-Ag), teluretos e sulfossais de Bi; a ganga é constituída por calcita e subordinadamente de quartzo. Na paragênese mineral são reconhecidos três eventos principais: o evento inicial dominado por abundante pirita, o evento intermediário dominado por esfalerita e o evento final dominado por calcita e subordinados sulfetos; o ouro foi depositado nos três eventos.

Apesar das informações geológicas no Distrito de Marmato serem abundantes, não se tinham dados geocronológicos da mineralização que permitiriam relaciona-la com a atividade magmática da região, em especial com a idade de formação do Stock de Marmato, 6.3 $\pm 0.7 \mathrm{Ma} \mathrm{K-Ar}$ em hornblenda (Restrepo et al.,1981); ou com o último evento de reativação do Sistema de Falhas de Cauca Romeral, 5.6 Ma $\pm 0.4 \mathrm{Ar}$-Ar em biotita (Vinasco, 2001). Da mesma forma, faltam informações sobre as rochas fontes dos fluidos hidrotermais; uma vez que, nos depósitos epitermais de tipo AdulariaSericita, a circulação dos fluidos hidrotermais-meteóricos é importante podendo o circuito hidrotermal espalhar-se por várias rochas encaixantes, ampliando as possiveis rochas fontes dos fluidos hidrotermais. 
No trabalho desta Dissertação de Mestrado foi proposto um estudo de geologia isotópica visando principalmente conhecer as possiveis rochas fontes dos fluidos hidrotermais e os processos de interação fluido-rocha, assim como para determinar a idade da mineralização. Foram tentadas duas técnicas distintas para obter a idade: Rb$\mathrm{Sr}$ em produtos lixiviados de esfalerita procurando obter a idade diretamente nos minerais de minério; e K-Ar em plagioclásio sericitizado da zona de alteração hidrotermal, procurando obter a idade final do resfriamento do sistema hidrotermal. Para conhecer os reservatórios isotópicos e as possiveis rochas encaixantes fontes dos fluidos hidrotermais, foi realizado um estudo de geoquímica isotópica visando caracterizar isotópicamente a mineralização para poder comparar-la com os valores isotópicos das rochas encaixantes regionais.

As técnicas isotópicas trabalhadas na Geoquímica isotópica, incluem as sistemáticas: $\mathrm{Sr} / \mathrm{Sr}, \mathrm{Pb} / \mathrm{Pb}$ e $\mathrm{Sm}-\mathrm{Nd}$ em minerais de minério, ganga e rochas encaixantes. A sistemática $\mathrm{Sr} / \mathrm{Sr}$ foi utilizado em, pirita, esfalerita e calcita, minerais pertencentes aos três eventos paragenéticos que ocorrem na área; a sistemática $\mathrm{Pb} / \mathrm{Pb}$ foi utilizado em galena, pirita e esfalerita, pertencentes aos dois primeiros eventos paragenéticos; a sistemática $\mathrm{Nd} / \mathrm{Nd}$ foi utilizada em pirita pertencente ao primeiro evento paragenético. As amostras foram coletadas nos diferentes niveis do sistema hidrotermal, setores de Echandía (superficial), Cien Pesos (intermediario) e Marmato Bajo (profundo); já as rochas encaixantes incluíram os Andesito-Dacito Pórfiro, o Complexo Arquia, o Stock de Támesis e a Formação Combia.

O estudo permitiu caracterizar isotópicamente as mineralizações de ouro do Distrito de Marmato, propor algumas rochas encaixantes como fontes e contaminantes dos fluidos hidrotermais, alem de fazer inferências sobre as variações isotópicas dos fluidos nos diferentes níveis do sistema hidrotermal e nos eventos da paragênese mineral. Os resultados obtidos neste estudo, realizado em mineralizações auríferas epitermais em ambientes de arcos magmáticos conhecidos, poderão servir para comparação com depósitos similares nos Andes e no Brasil. 


\subsection{OBJETIVOS DO PROJETO}

O objetivo maior desta pesquisa foi estudar mineralizações de ouro epitermais em ambientes geológicos conhecidos, visando o estabelecimento de modelos conceituais destas mineralizações, para melhorar a compreensão dos processos envolvidos neste tipo de sistemas hidrotermais. Para tanto foi selecionado para estudo o Distrito Mineiro de Marmato (Colômbia), que além de ocorrer em ambiente de arco magmático andino, possui uma idade bastante jovem, onde as suas principais feições geológicas estão preservadas. Para este trabalho os objetivos específicos foram:

- Determinar a assinatura isotópica das mineralizações de ouro de Marmato, sistemáticas: $\mathrm{Sr} / \mathrm{Sr}, \mathrm{Pb} / \mathrm{Pb}$ e $\mathrm{Nd} / \mathrm{Nd}$.

- Determinar as razões isotópicas de algumas das rochas encaixantes, sistemáticas: $\mathrm{Sr} / \mathrm{Sr}, \mathrm{Pb} / \mathrm{Pb}$ e $\mathrm{Nd} / \mathrm{Nd}$.

- Propor possiveis fontes isotópicas dos fluidos hidrotermais, a partír de uma comparação da assinatura isotópica da mineralização e os valores isotópicos das rochas encaixantes.

- Obter a idade da mineralização de ouro e/ou de resfriamento do sistema hidrotermal. Métodos: K-Ar em plagioclásio com alteração hidrotermal; e $\mathrm{Rb}-\mathrm{Sr}$, em produtos lixiviados de esfalerita.

\subsection{LOCALIZAÇÃO DA ÁREA DE ESTUDO}

A área de estudo localiza-se na Colômbia, no Departamento de Caldas (Estado), politicamente faz parte do município de Marmato; o qual está situado a $50 \mathrm{~km}$ ao N-NW de Manizalez, cidade capital do Estado. 
Geograficamente, o Município encontra-se no flanco leste da Cordilheira Ocidental da Cadeia Andina Colombiana, nas serranias adjacentes ao Rio Cauca. Sua cota mínima é de $600 \mathrm{~m}$ de altitude no nível do Rio Cauca, e sua cota máxima é de $1800 \mathrm{~m}$ de altitude na parte alta do setor de Echandía, e de $1650 \mathrm{~m}$ de altitude no Alto do Burro; a morfologia é abrupta e o declive alto. Referente ao clima, a região tem dois períodos de chuva de Abril-Junho e Outubro-Novembro; a precipitação média anual é de $2100 \mathrm{~mm}$, e a temperatura média é de $20^{\circ} \mathrm{C}$.

A principal via da região é a rodovia Pan-americana (Troncal de Ocidente) que liga as cidades de Medellín com Pereira, capitais dos estados de Antioquia e Risaralda; à altura do Km 110 de Medellín, no local conhecido como La Felisa, parte um acesso ao município de Marmato, que dista cerca de $7 \mathrm{~km}$ deste ponto. Outra via alternativa que tem acesso à rodovia Pan-americana, é um caminho pouco conservado que une os municípios de Marmato, San Juan e Supía (Figura 1). 


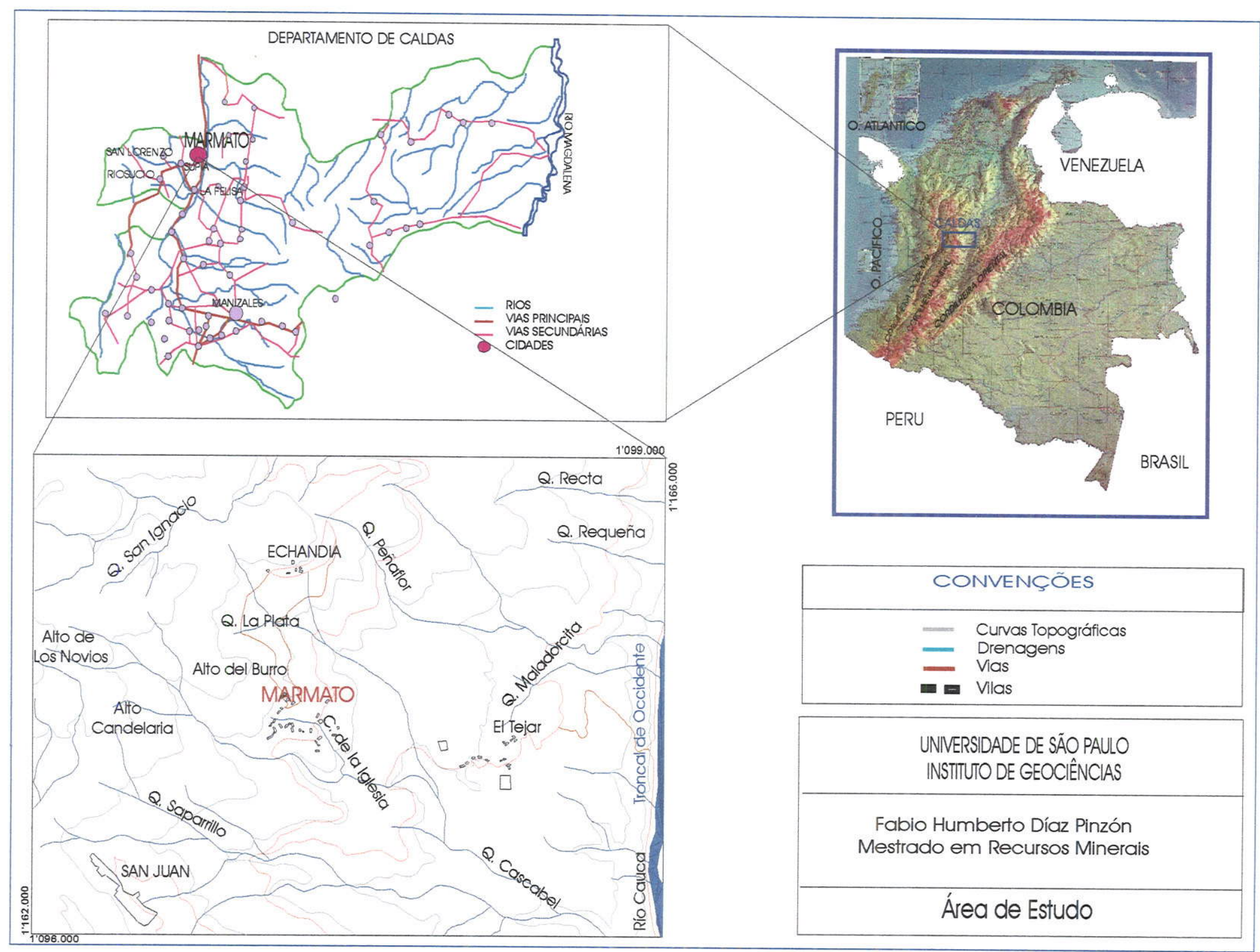

Figura 1. Localização da Área de Estudo 


\section{MÉTODO E MATERIAIS}

O projeto de Pesquisa foi dividido nas seguintes etapas de trabalho: levantamento bibliográfico, duas fases de campo para amostragem, descrição petrográfica e mineralógica das amostras para análises isotópicas, análises isotópicas e interpretação dos resultados, conforme demonstrado na Figura 2.

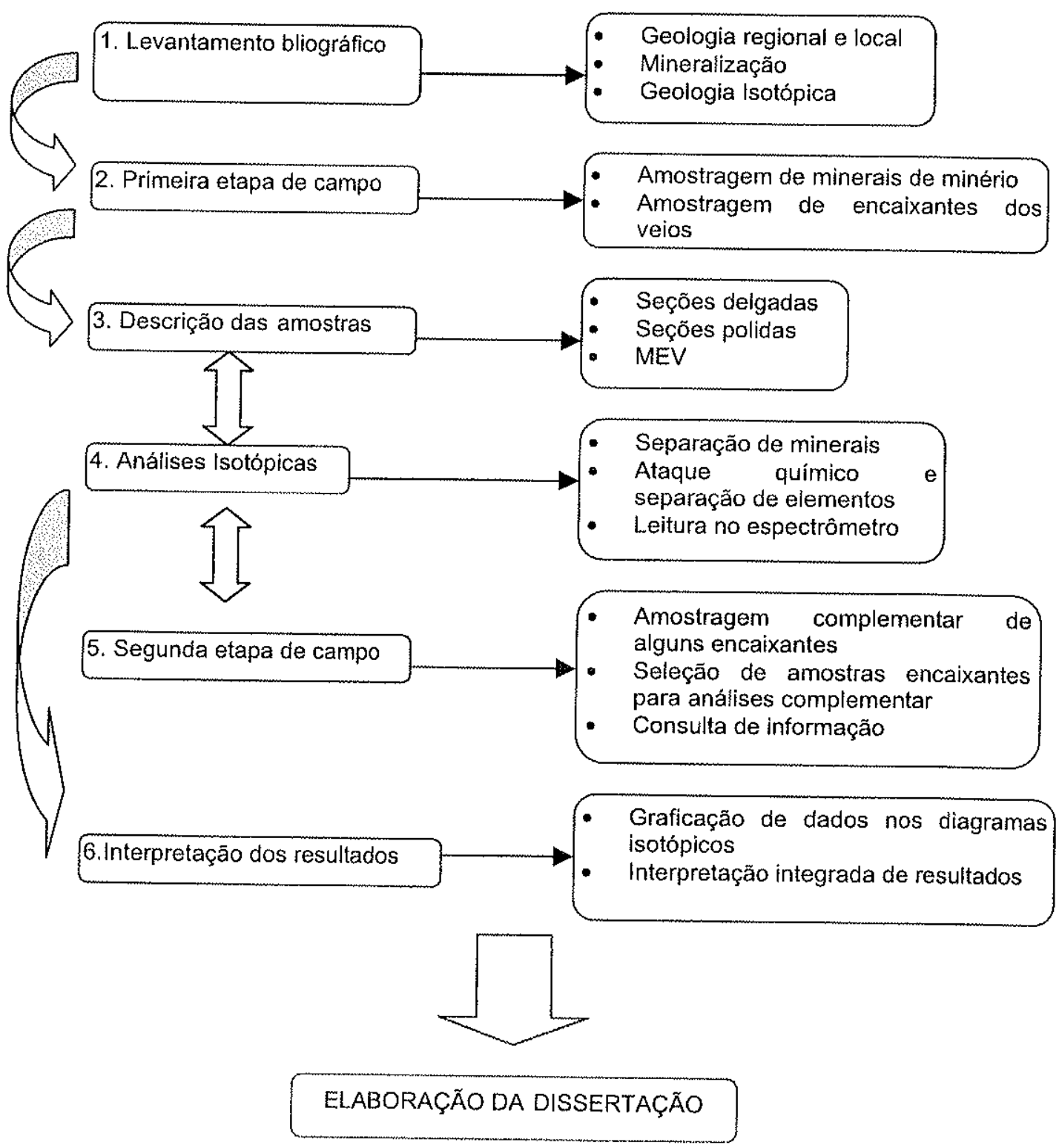

Figura 2. Atividades desenvolvidas no projeto de Pesquisa 
A seguir é apresentada uma breve descrição das atividades realizadas e dos materiais e métodos utilizados neste trabalho.

\subsection{LEVANTAMENTO BIBLIOGRÁFICO}

O Distrito Mineiro de Marmato tem sido objeto de muitos estudos por parte de diferentes pesquisadores, principalmente no que se refere à mineralização, e nos aspectos relacionados como alterações minerais, descrição mineralógica e paragêneses mineral que foram abordados, entre outros, por: Rossetti et al. (1999), Bedoya (1998), Buenaventura (1997), López-Rendón (1991), López-Rendón e Bedoya (1989), Zapata e Peláez (1991), Molina (1991), Alvarez (1989), Monsalve (1989), Medina (1989), Restrepo (1989), Cadavid e Escovar (1991). No que se refere à Geologia regional, o mapeamento geológico foi feito por Calle et al. (1984) e González et al. (1980) das folhas na escala 1: 100.000, 186 Riosucio e 187 Salamina editadas pelo INGEOMINAS (Serviço Geológico da Colômbia); já na geologia local são importantes, entre outros, trabalhos como: Cuellar et al. (1982), Alvarez e Arias (1970). Já para informação mais gerais sobre Marmato foram consultados: Botero e Zuluaga (1980), Chamorro (1984), Gómez e Rodríguez (1988), Ingeominas (1988, 1993, 1995, 1999), Martinez e Córdoba (1989), Ortíz (1999), Ortíz et al. (1987), Rodríguez (1993), Rubiano (1986), Sillitoe et at. (1982), Lozano e Pulido (1986), Calle et al. (1980), Calle e González (1982), Maya (1992), Vinasco et al. (2001), Restrepo e Toussaint (1982), Restrepo et al. (1991). Também foram consulatdos: Keio et al. (1995), Stipp (1995), Torquato e Kawashita (1990, 1991, 1992, 1994), Doe (1970), Faure e Powell (1972), MacFatlane (1995), Gulson (1986), Tassinari (1999b), U.S.G.S. (1986), Hutchinson (1983), Mitchell e Garson (1981), Sawkins (1990), Hedenquist e Lowenstern (1994), Hedenquist e Gulson (1992), Hedenquist et al. (1994), Giggenbach (1992), Heald et al. (1987), Corbett e Leach (1998). 


\subsection{COLETA DE AMOSTRAS}

A coleta de amostras foi realizada na parte superficial, intermediaria e profunda do Distrito Mineiro de ouro de Marmato, procurando desta forma conseguir uma distribuição adequada da amostragem e assim obter informação isotópica mais representativa. Na parte superficial do sistema hidrotermal, no setor de Echandía situado entre 1600 e 1450 metros de altitude, foram amostradas as minas Plata Fria e La Palma; na parte intermedia ou setor de Cien Pesos situado entre 1450 e 1300 metros de altitude, foram coletadas amostras das minas Villonza, La Mona e La Ratonera; na parte profunda, setor de Marmato Bajo, a coleta realizou-se em veios dos níveis 1260,1210 e 1160 metros de altitude (Tabela1, Figura 4 e 5).

A amostra foi coletada buscando que fosse representativa do afloramento e evitando amostras intemperisadas; por isto a amostragem foi realizada diretamente nos frentes de extração do minério. No possível, foram amostrados os veios, as rochas encaixantes perto do contato com os veios, e a rocha hospedeira afastada do veio (uns poucos metros). Nas amostras dos veios foram posteriormente separados os sulfetos: pirita, esfalerita, galena e dos minerais de ganga a calcita; de uma das encaixantes dos veios, afetadas por alteração hidrotermal, foi coletada a amostra FHD-24 e posteriormente separado o plagioclásio sericitizado (Figura 3).

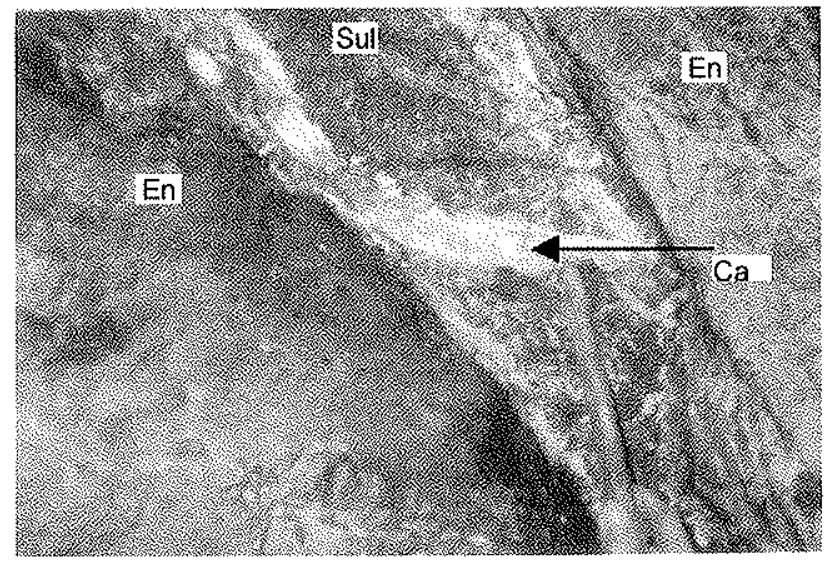

Figura 3. Aspecto do Veio onde foi coletada a amostra FHD-19. Calcita (Ca), Sulfeto (Sul), Encaixante (En) 


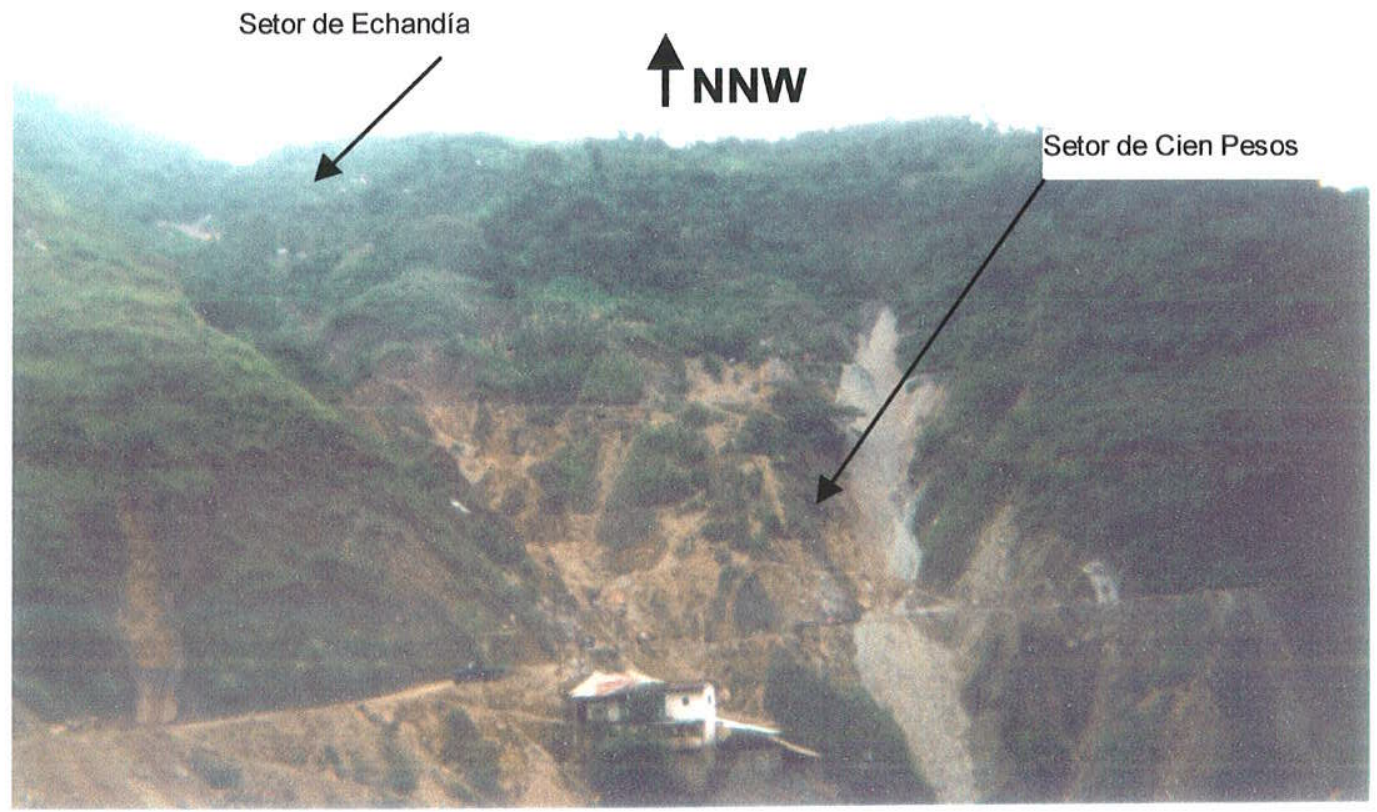

A

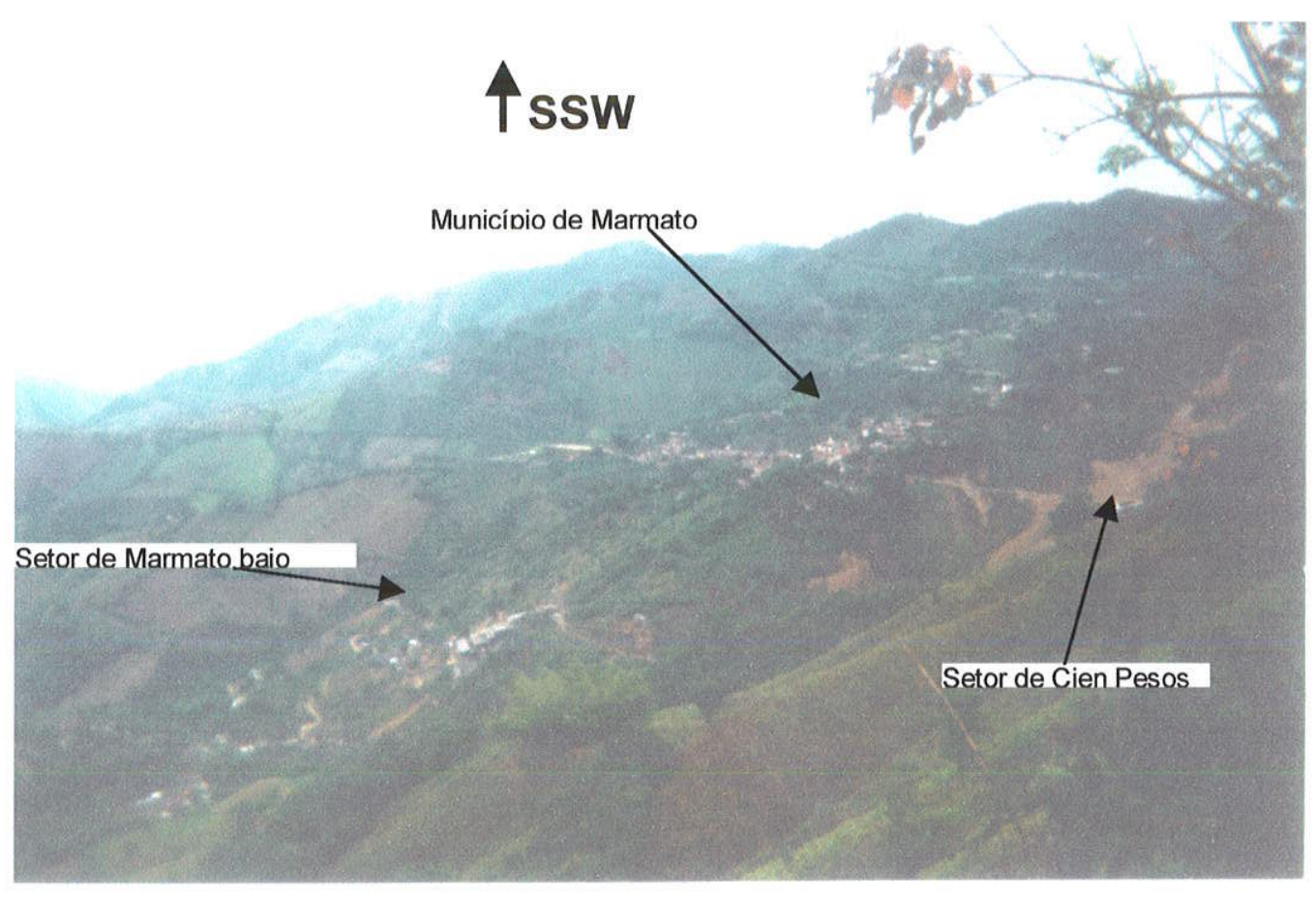

B

Figura 4. Fotografia da região de Marmato. A)Setor de Echandia e Setor de Cien Pesos. B) Setor de Marmato bajo 


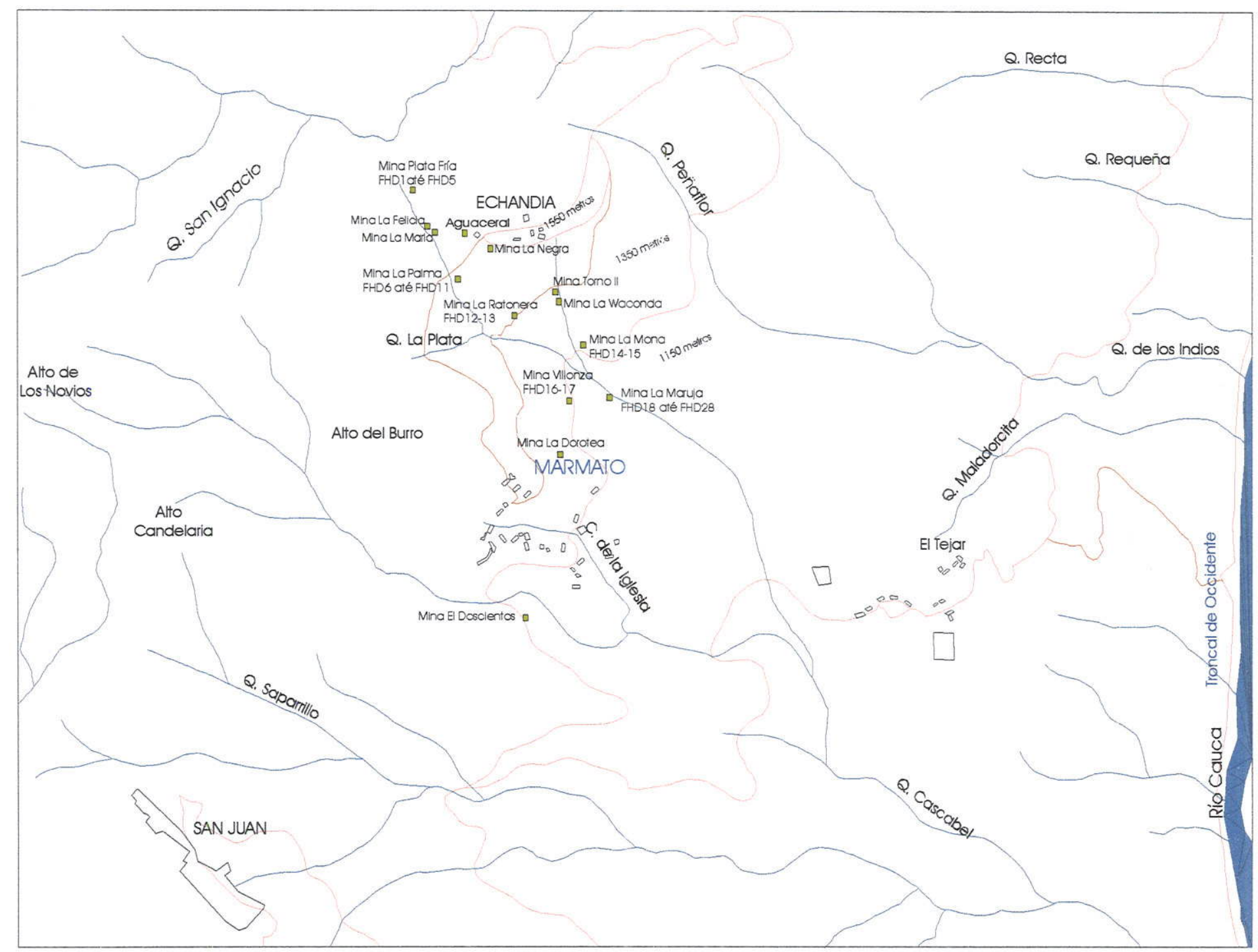

Figura 5. Localização das minas e das amostras coletadas no Distrito Mineiro de Marmato 
Tabela 1. Relação de Amostras coletadas e análises realizados

\begin{tabular}{|c|c|c|c|c|c|c|}
\hline \multirow[t]{2}{*}{$\mathrm{N}^{\circ}$ de Campo } & \multirow[t]{2}{*}{ Descrição } & \multirow[t]{2}{*}{ Localidade } & \multicolumn{4}{|c|}{ Amostra } \\
\hline & & & Rocha & SD & SP & MEV \\
\hline FHD-1 & Veio de carbonatos com sulfetos & Echandia, mina Plata Fría, cota $1550 \mathrm{~m}$ & & & & \\
\hline FHD-2 & Veio de quartzo com sulfetos & Echandia, mina Plata Fría, cota $1550 \mathrm{~m}$ & & & & $\cdots$ \\
\hline FHD-3 & Veio com alteração fílica & Echandia, mina Plata Fría, cota $1550 \mathrm{~m}$ & ए० & & & \\
\hline FHD-4 & Pórfiro com propilitização & Echandia, mina Plata Fria, cota $1550 \mathrm{~m}$ & & & & \\
\hline FHD-5 & Andesito Pórfiro com propilitização & Echandia, mina Plata Fria, cota $1550 \mathrm{~m}$ & खे & 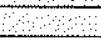 & & \\
\hline FHD-6 & Xistos grafitosos & Ecahndia, cota $1500 \mathrm{~m}$ & & & & \\
\hline FHD-7 & Veio de sulfetos dentro de encaixante & Echandía, mina la Palma, cota $1450 \mathrm{~m}$ & & & & \\
\hline FHD-8 & Póriro com propilitização e mineralização & Echandia, mina la Palma, cota $1450 \mathrm{~m}$ & & & & \\
\hline FHD-9 & Rocha com alteração fílica & Echandía, mina la Paima, cota $1450 \mathrm{~m}$ & & & & \\
\hline FHD-10 & Xistos grafitosos & Echandía, mina la Palma, cota $1450 \mathrm{~m}$ & & & & \\
\hline FHD-11 & Pórfiro com propilitização & Echandíia, mina la Palma, cota $1450 \mathrm{~m}$ & ४म & es & & \\
\hline FHD-12 & Veio de sulfetos & Cien Pesos, mina la Ratonera, cota $1350 \mathrm{~m}$ & & & & \\
\hline FHD-13 & Rocha com alteraçăo e sulfetos & Cien Pesos, mina la Ratonera, cota $1350 \mathrm{~m}$ & मि & & & \\
\hline FHD-14 & Veio de pirita, com menor calcita & Cien Pesos, mina la Mona, cota $1300 \mathrm{~m}$ & & & & \\
\hline FHD-15 & Rocha com alteraçäo filica, pirita em veios & Cien Pesos, mina la Mona, cota $1300 \mathrm{~m}$ & & & & \\
\hline FHD-16 & Rocha com alteração e mineralização & Cien Pesos, mina Villonza, cota $1300 \mathrm{~m}$ & & & & \\
\hline FHD-17 & Pórfiro com alteração filica, com piritas & Cien Pesos, mina Villonza, cota $1300 \mathrm{~m}$ & & & & \\
\hline FHD -18 & Pórfiro com alteraçāo filica, com piritas & Marmato Bajo, cota $1260 \mathrm{~m}$ & 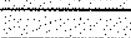 & & & \\
\hline FHD-19 & Veio com suifetos & Marmato Bajo, cota $1260 \mathrm{~m}$ & & & & \\
\hline FHD-20 & Pórfiro propilitizado & Marmato Bajo, cota $1260 \mathrm{~m}$ & & & & \\
\hline FHD-21 & Veio com sulfetos & Marmato Bajo, cota $1260 \mathrm{~m}$ & & & & \\
\hline FHD-22 & Veio com sulfetos & Marmato Bajo, cota $1260 \mathrm{~m}$ & & & & \\
\hline FHD-23 & Veio com sulfetos & Marmato Bajo, cota $1210 \mathrm{~m}$ & & & & \\
\hline FHD -24 & Dacito Pórfiro com alteraçāo propilitica e filica & Marmato Bajo, cota $1160 \mathrm{~m}$ & & बल & & \\
\hline FHD-25 & Veio com sulfetos & Marmato Bajo, cota $1160 \mathrm{~m}$ & म. & & & \\
\hline FHD-26 & Brecha Hidrotermal & Marmato Bajo, cota $1160 \mathrm{~m}$ & ॠे & & & \\
\hline FHD-27 & Brecha Hidrotermal & Marmato Bajo, cota $1160 \mathrm{~m}$ & & & & \\
\hline FHD-28 & Pórfiro com leve sericitização & Marmato Bajo, cota $1160 \mathrm{~m}$ & & & & \\
\hline FHD 29 & Pórfiro & Poblado de San Juan & खि & & & \\
\hline FHD-30 & Pórfiro com alteraçâo hidrotermal & Carreteira San Juan-Marmato & & & & \\
\hline C. $3-01$ & Latítico Pórfiro & Corrego Chirapoto & 3 & s. & & \\
\hline $\mathrm{CJ}-02$ & Piroxenito & Corrego Chirapoto & & & & \\
\hline $\mathrm{CJ}-03$ & Xisto quartzo biotitico & Corrego Chirapoto & & & & \\
\hline CJ-04 & Xisto Anfibólico & Corrego Chirapoto & & & & \\
\hline CJ-06 & Xisto Anfibólico & Corrego Chirapoto & & & & \\
\hline CJ-66A & Dacito Pórfiro & Corrego Chirapoto & mल & m & & \\
\hline IGM-6921 & Microquarzodiorito Porfidico & Marmato & & & & \\
\hline IGM-119089 & Basalto & SW Jardin & & & & \\
\hline IGM-8763 & Diorito hombléndico & S Támesis & & & & \\
\hline IGM-6912 & Dunito serpentinizado & Rodovia Medellin-Manizalez & & & & \\
\hline \multicolumn{7}{|l|}{ CONVENÇOES } \\
\hline $\begin{array}{ll}\text { FHD: } & \text { Fabio HL } \\
\text { CJ: } & \text { Cesar Ja } \\
\text { IGM: } & \text { ingeomir } \\
\text { SD: } & \text { Seção dd } \\
\text { SP: } & \text { Seção ph } \\
\text { MEV: Microscc }\end{array}$ & $\begin{array}{l}\text { berto Diaz Pinzón } \\
\text { er Vinasco } \\
\text { s } \\
\text { lada } \\
\text { da } \\
\text { lo de varredura elet }\end{array}$ & & & & & \\
\hline
\end{tabular}


Para comparar as razões isotópicas dos veios com as de rochas encaixantes; coletaram-se algumas amostras do Andesito-Dacito Pórfiro e dos xistos grafitosos. Além disto outras rochas encaixantes dos corpos subvulcânicos e das unidades geológicas regionais foram cedidas e emprestadas pelo INGEOMINAS e pelo Geólogo César Javier Vinasco (Tabela 1, Figura 17).

\subsection{DESCRIÇÃo PETROGRÁFICA E MINERALÓgICA DAS AMOSTRAS PARA ANÁLISES ISOTÓPICAS.}

A descrição das seções delgadas e polidas foi realizada com o objetivo de selecionar as amostras para análises isotópicas e auxiliar a interpretação dos resultados obtidos. As observações feitas, foram aproveitadas também para a descrição da mineralização.

Em total, foram realizadas 15 descrições petrográficas de seções delgadas, 10 de seção polida e 7 no Microscópio Eletrônico de Varredura (MEV) (Tabela 1); no caso das amostras das emcaixantes e das unidades regionais, observaram-se 10 laminas delgadas. Os equipamentos utilizados foram: microscópio Olympus BXP-40 para as seções delgadas e o microscópio tipo Zeiss Axioplan e Axioplan 2 com câmara XCOO3P Sony e analisador Leica qwin 550W, para os polidos. O MEV do Instituto de Geociências da USP é do tipo Leo 440i com espectrômetro de energia dispersiva RX de estado sólido Si-Li, Oxford.

$\mathrm{Na}$ descrição das seções delgadas, os principais aspectos levados em conta foram: reconhecimento mineralógico dos carbonatos analisados isotópicamente; reconhecimento da composição mineralógica e do tipo de alteração hidrotermal das encaixantes.

Nas seções polidas o trabalho centrou-se no reconhecimento de minerais de minério, aspectos texturais, e interpretação paragenética da amostra. Para as análises isotópicas é importante reconhecer minerais acessórios e inclusões dentro dos minerais principais e também a composição do material de preenchimento das fraturas. 
O MEV foi usado para fins específicos: a) determinar o material de preenchimento das fraturas e minerais acessórios e microcristais dentro da esfalerita da amostra FHD-19. b) reconhecer os minerais associados às galenas; c) caracterizar os minerais associados ao ouro; d) determinar a composição de alguns minerais não identificados; e)verificar a presença e composição de inclusões sólidas.

\subsection{PREPARAÇÃO DAS AMOSTRAS PARA ANALISES ISOTÓPICAS.}

A etapa de preparação das amostras para análises isotópicas consistiu na separação dos minerais e na preparação de rocha total. A seguir se apresenta uma descrição das técnicas utilizadas.

\subsubsection{SEPARAÇÃO DE MINERAIS}

Para a separação de minerais, foram selecionadas as amostras mais adequadas para fins isotópicos de acordo aos objetivos do projeto. Os minerais separados foram: pirita, esfalerita, galena, carbonato e plagioclásio alterado.

O procedimento seguido incluiu: I) trituração das amostras em pilão de ferro, e peneiramento até a malha 35-60, algumas até 60-100; II) lavagem com água no béquer e posteriormente com álcool; e III) secagem na lâmpada.

Os minerais lavados e secados separaram-se por meio denso com auxilio do lodeto de Metileno e Bromoformio; os sulfetos concentraram-se na fase densa e o plagioclásio e carbonatos na de menor densidade; posteriormente foi separado cada mineral em particular:

- As esfaleritas separaram-se dos demais sulfetos com ajuda do separador eletromagnético de tipo: Frantz Isodynamic, modelo $L 1,115 \mathrm{~V}, 2,2 \mathrm{~A}$, série 678 . 
(Possivelmente por sua alta proporção de ferro têm propriedades magnéticas; ou podem conter inclusões de magnetita).

- As galenas coletaram-se por catação manual com auxilio de lupa binocular.

- Para a separação das piritas, fol feita uma purificação do concentrado final por catação manual, dada sua abundância.

- Para as calcitas, inicialmente foram isolados manualmente fragmentos de carbonato dos veios que posteriormente foram purificadas pelos líquidos densos (bromoformio e lodeto de Metileno) e finalmente por catação manual com auxilio de lupa binocular.

- O plagioclásio foi separado da rocha por densidade, utilizando o bromofórmio e lodeto de Metileno, posteriormente foi adicionado $\mathrm{HCl}$ para eliminar o carbonato, e finalmente foi purificado por catação manual com auxilio de lupa binocular.

\subsubsection{ROCHA TOTAL}

As amostras selecionadas para análises de rocha total foram trituradas no pilão de ferro, posteriormente quarteadas e pulverizadas em moinho de bolas com cápsula revestida em carbeto de tungstênio; neste caso o moinho usado foi marca Spex 8000 Mixer/Mill.

\subsection{ANÁLISES ISOTÓPICAS}

As análises isotópicas propostas para o Distrito Mineiro de Marmato, foram realizadas em minerais de minério e de ganga e ainda de alguns das rochas encaixantes. A fase de análises isotópicas foi realizada nos Laboratórios do Centro de Pesquisas Geocronológicas (CPGeo).

Os sistemas isotópicos utilizados no presente trabalho foram: $\mathrm{Rb}-\mathrm{Sr}, \mathrm{Pb} / \mathrm{Pb}, \mathrm{Sm}$ Nd e K-Ar. Para obter informações sobre a fonte dos fluidos hidrotermais, utilizaram-se as razões isotópicas: ${ }^{87} \mathrm{Sr} /{ }^{86} \mathrm{Sr}, \mathrm{Pb} / \mathrm{Pb}$ e ${ }^{143} \mathrm{Nd} /{ }^{144} \mathrm{Nd}$. Para determinar a idade tentativa 
da mineralização utilizaram-se as metodologias $\mathrm{Rb}-\mathrm{Sr}$ (Lixiviação em esfalerita) e $\mathrm{K}$-Ar (em plagioclásio sericitizado) (Tabela 2).

De modo geral o procedimento seguido nas análises isotópicas divide-se em três etapas: Ataque químico, separação de elementos e leitura no espectrômetro. A seguir serão descritos os procedimentos de cada uma das técnicas utilizadas.

\subsubsection{MÉTODO Rb-Sr}

O método Rb-Sr foi utilizado para determinar a idade da mineralização (técnica de lixiviação em esfaleritas); assim como para obter as razões isotópicas ${ }^{87} \mathrm{Sr} /{ }^{86} \mathrm{Sr}$ da mineralização e das rochas encaixantes.

Inicialmente, nas amostras trabalhadas por este método, foi determinado o conteúdo de $\mathrm{Rb}$ e $\mathrm{Sr}$ através de análises quantitativos por fluorescência de raios $\mathrm{X}$, usando um equipamento modelo 2400, marca Philips.

\subsubsection{Técnica de Lixiviação em Esfalerita}

A lixiviação de esfalerita foi feita na amostra FHD-19, a qual localiza-se no setor de Marmato bajo. A esfalerita uma vez separada, foi analisada por difratometria de raios $X$ usando um equipamento marca Siemens, $D 5000,40 \mathrm{kV}, 40 \mu \mathrm{A}$ com varredura de 3 a 75; o programa utilizado na interpretação dos resultados foi o DIFRAC AT, versão 2.01, da Siemens (1997); a amostra foi confirmada como esfalerita pura. A lixiviação foi feita seguindo a técnica de diluição isotópica, o procedimento consiste em ataques sucessivos com $\mathrm{HCl}$ a diferentes temperaturas e concentrações, no resíduo final é usado $\mathrm{HNO}_{3}$, obtendo-se: 4 lixiviados, 1 dissolução total e 1 resíduo (Figura 6), posteriormente as amostras foram levadas para a coluna de separação de elementos e depois para leitura no espectrômetro. 
TABELA 2. Relação de análises isotópicas realizadas

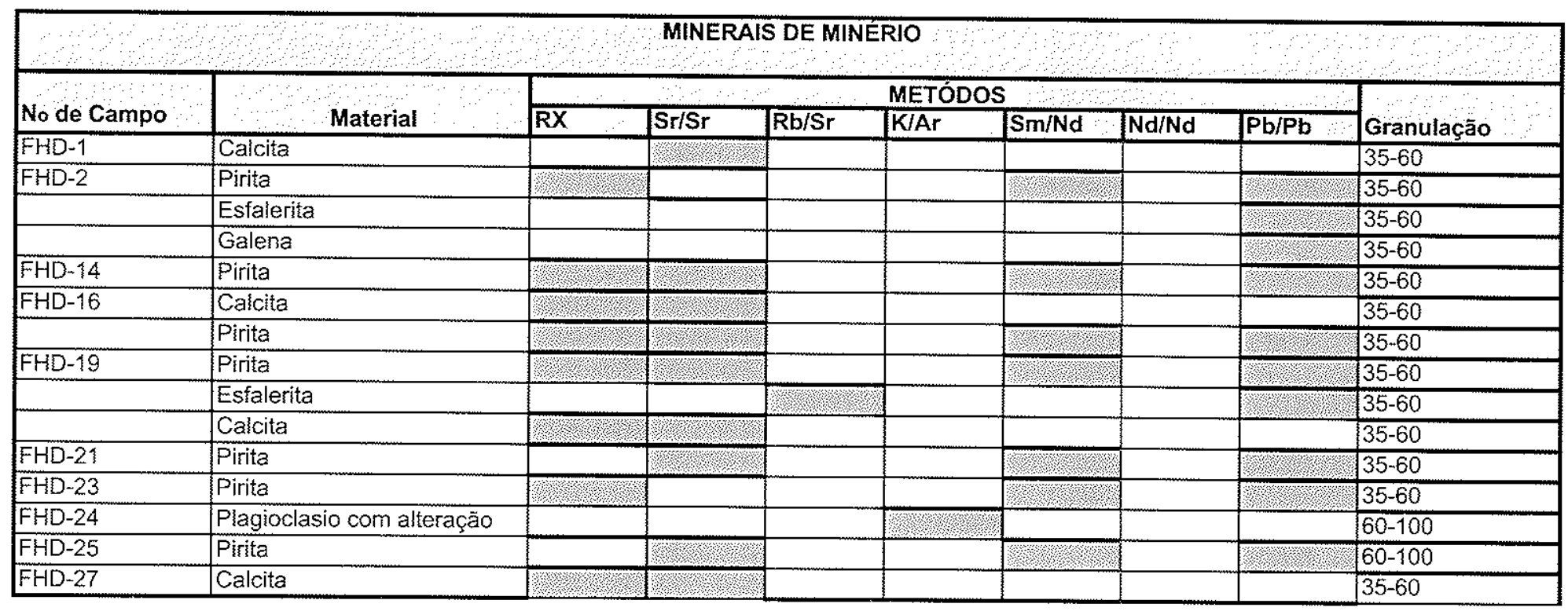

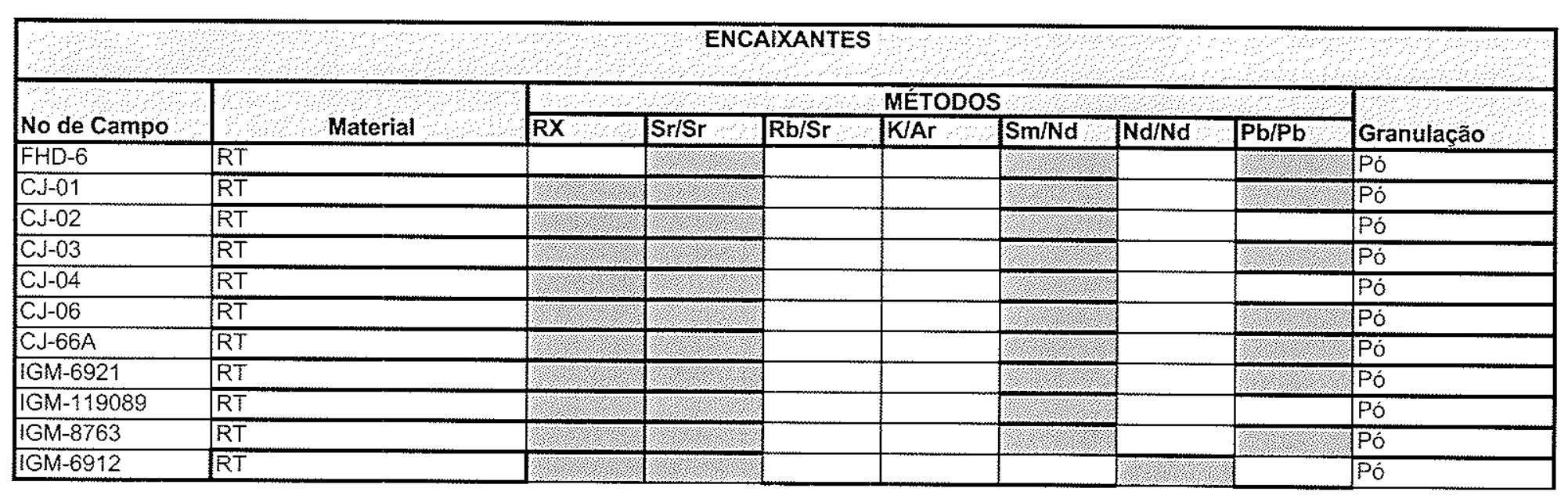



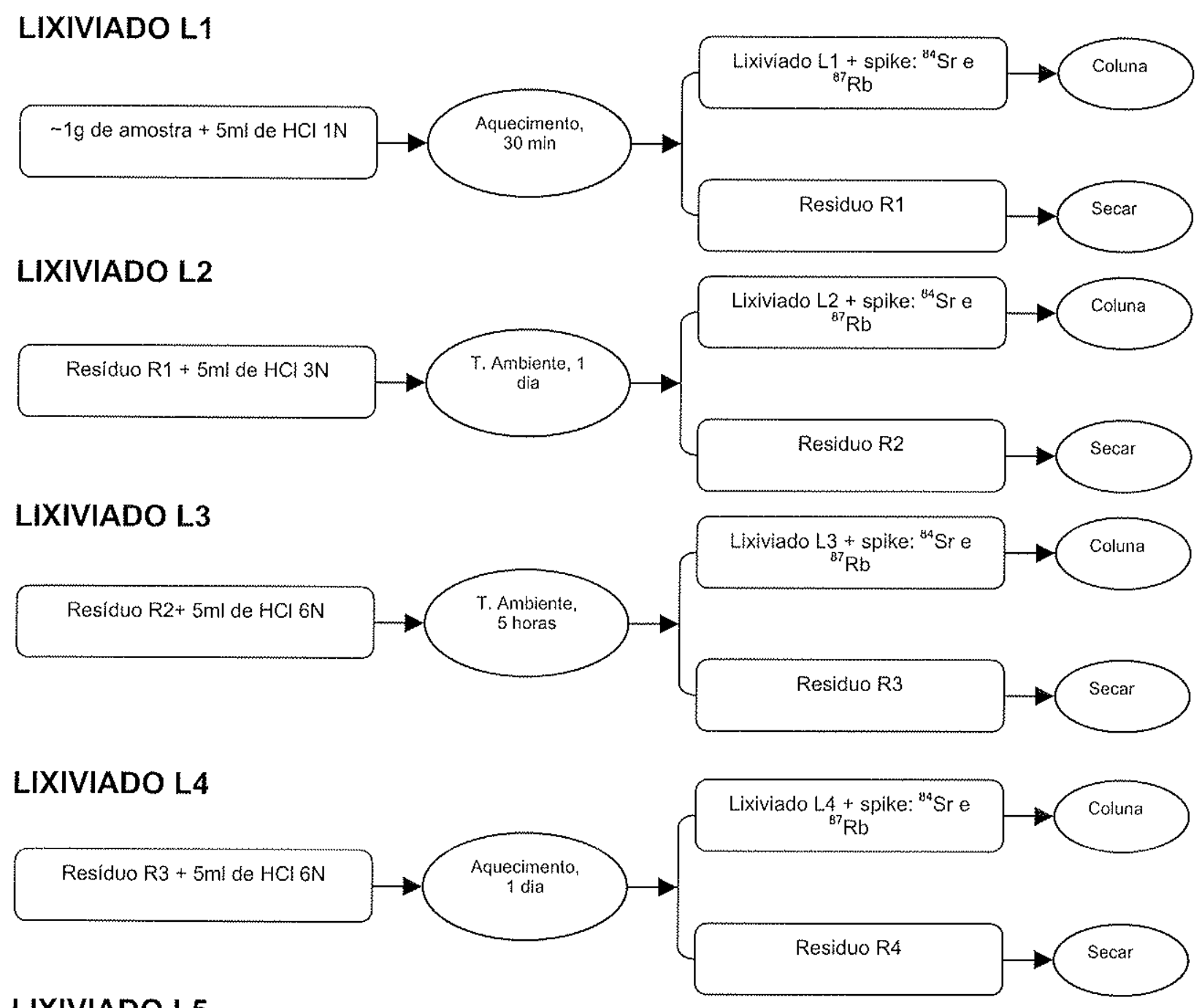

\section{LIXIVIADO L5}

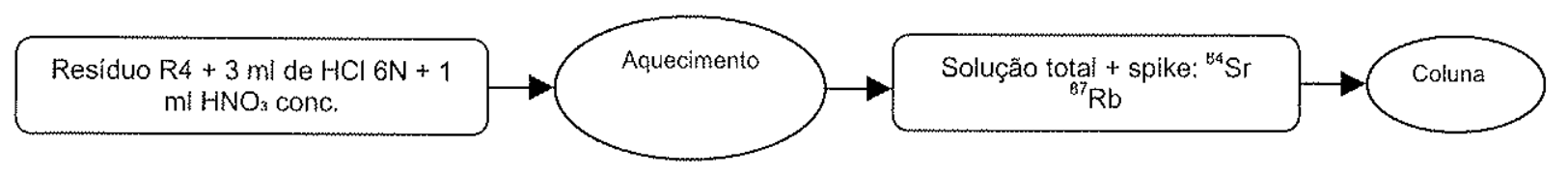

SOLUÇÃO TOTAL

$-0,5 \mathrm{~g}$ de amostra + spike: ${ }^{84} \mathrm{Sr}^{87} \mathrm{Rb}+3 \mathrm{mlde} \mathrm{HCl} 6 \mathrm{~N}+1 \mathrm{ml}$ de $\mathrm{HNO}_{3}$

Figura 6. Lixiviação em esfalerita, procedimento adotado no CPGeo 


\subsubsection{Determinações das razões isotópicas ${ }^{87} \mathrm{Sr} /{ }^{86} \mathrm{Sr}$}

As razões ${ }^{87} \mathrm{Sr} /{ }^{86} \mathrm{Sr}$ foram realizadas em: 5 piritas, 4 carbonatos, 1 esfalerita e 11 amostras de rocha total das encaixantes (Tabela 2).

Ataque Químico: $O$ ataque químico inicia-se com a separação de $100 \mathrm{mg}$ de amostra (utilizou-se a balança Toledo modelo AT 201), posteriormente procede-se à dissolução adicionando diferentes ácidos a variadas concentrações de acordo ao material presente. Nas piritas e esfaleritas, adicionou-se $\mathrm{HCl} 50 \%$ e $\mathrm{HNO}_{3} 50 \%$ na relação de 3 a 1; para os carbonatos $\mathrm{HCl}$; e no caso da rocha total $\mathrm{HNO}_{3}, \mathrm{HF}$ e $\mathrm{HCl}$ (Figura 7).

Separação de elementos: Para a separação dos elementos nas colunas de troca iônica, o laboratório do CPGeo utiliza colunas de resina catiônica (AG-50 WX8, 200-400 mesh), o procedimento usado descreve-se a seguir: 1) Centrifugação da amostra; 2) Refluxo nas colunas; 3) Escoamento de todo o ácido e inicio da deposição da amostra; 4) Coleta do $\mathrm{Rb}$ ou $\mathrm{Sr}$, de acordo com a calibração, usando $\mathrm{HCl} 2,62 \mathrm{~N}$; 5 ) Adição de algumas gotas de $\mathrm{HNO}_{3}$, e colocação em evaporador até secura; 6) A amostra pode ser levada ao espectrômetro; 7) Regeneração da resina com $\mathrm{HCl} 6 \mathrm{~N}$.

Leitura no espectrômetro: Utilizou-se um espectrômetro VG 354, monocoletor, com filamento simples de $\mathrm{Ta}$, amostra depositada com $\mathrm{H}_{3} \mathrm{PO}_{4}$.

\subsubsection{MÉTODO $\mathrm{Pb} / \mathrm{Pb}$}

$\mathrm{O}$ método $\mathrm{Pb} / \mathrm{Pb}$ foi realizado em: 7 piritas, 2 esfaleritas, 1 galena e 7 amostras de rocha total das encaixantes (Tabela 2). O procedimento seguido consistiu no ataque químico e separação de minerais, como é descrito a seguir:

Ataque Químico: Das amostras de minerais e rocha total foram separados 100 mg em balança Toledo (modelo AT 201) e posteriormente foram atacados quimicame 


\section{Método $\mathrm{Sr} / \mathrm{Sr}$}

\section{CARBONATOS}

\section{ROCHA TOTAL}

- Colocar os carbonatos em tubos de polietileno

- Adicionar $2 \mathrm{mi}$ De $\mathrm{HCl} 0,1 \mathrm{~N}$

- Centrifugação

- Eliminação do sobrenadante

- Resíduo com $1 \mathrm{ml}$ de $\mathrm{HCl} 1 \mathrm{~N}$ até dissolução completa

- Centrifugação

- Sobrenadante secar na capela

- Eluidos com HCl, $\mathrm{HCl} 2,62 \mathrm{~N}$

- Coloca-se 0,1 de amostra no savilex

- Adiciona-se $1 \mathrm{ml}$ de $\mathrm{HNO}_{\text {s }}$ concentrado e $2 \mathrm{ml}$ de $\mathrm{HF}$

- Ultra-som por $60 \mathrm{~min}$

- Aquecimento 1 noite, lâmpada

- Evaporar até secura, lâmpada

- Dissolve-se com $\mathrm{HCl} 6 \mathrm{~N}$ e 1 noite sob lâmpada

- Evaporar até a secura e dissolve-se com $\mathrm{HCl} 2,62 \mathrm{~N}$

- Tubo centrifuga

\section{Método $\mathrm{Pb} / \mathrm{Pb}$}

\section{PIRITA E ESFALERITA}

- Pesar 80 mg de amostra

- Adicionar as amostras nas bombas

- Adicionar $1 \mathrm{ml}$ de $\mathrm{HCl}(50 \%) 6 \mathrm{~N}+1 \mathrm{ml}$ de $\mathrm{HNO}_{3}$ (50\%) $7 N$

- Aquecer em Chapa por 1 noite

- Evaporar Solução

- Adicionar $\mathrm{HNO}_{3}$ concentrado

- Centrifugar e retirar o residuo

- Evaporar

- Adicionar $1 \mathrm{ml} \mathrm{de} \mathrm{HBr} \mathrm{0,7} \mathrm{N}$

- Coluna Rápida

\section{GALENA}

\section{ROCHA TOTAL}

- Pesar $100 \mathrm{mg}$ de amostra

- Adicionar as amostras nas bombas

- Adicionar $3 \mathrm{ml}$ de HF concentrado + $1 \mathrm{ml}$ de $\mathrm{HNO}_{3}$ concentrado

- Deixar em estufa a $150^{\circ} \mathrm{C}$ por 5 dias

- Evaporar solução

- Adicionar $6 \mathrm{ml}$ de $\mathrm{HCl} 6 \mathrm{~N}$

- Deixar em estufa a $150^{\circ} \mathrm{C}$ por una noite

- Passar solução, para béquer e evaporar

- Adicionar $1 \mathrm{ml}$ de $\mathrm{HBr} 0.7 \mathrm{~N}$

- Coluna rápida

- Uma ou duas galenas

- Adicionar $\mathrm{HCl} 6 \mathrm{~N}$

- Coluna rápida

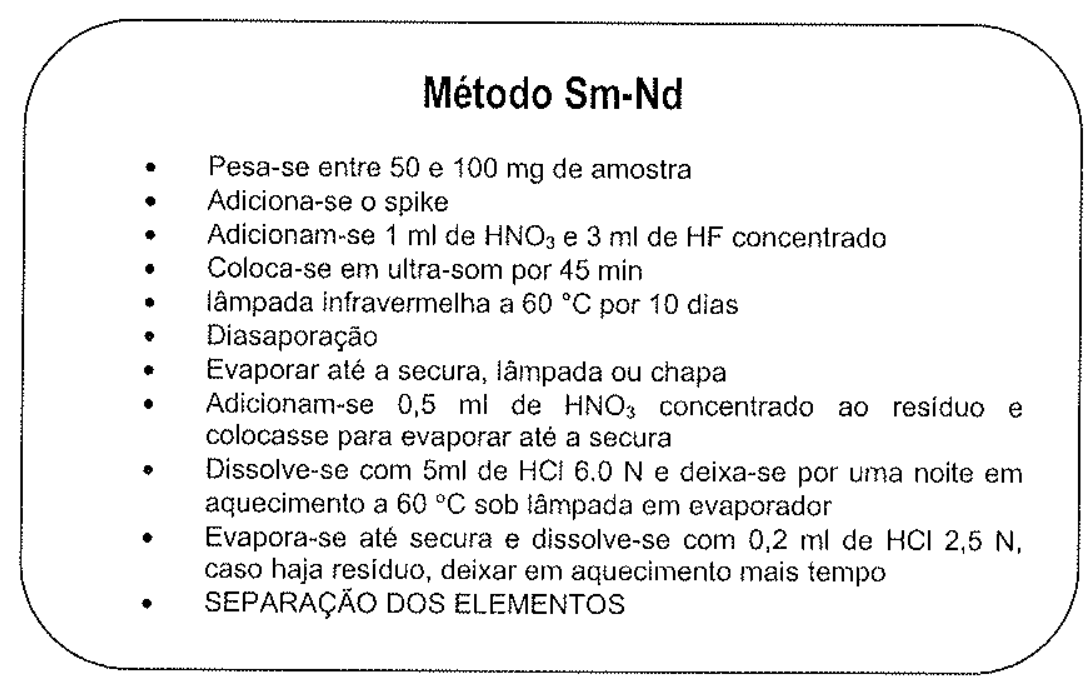

Figura 7. Ataque Químico, Métodos: $\mathrm{Sr} / \mathrm{Sr}, \mathrm{Pb} / \mathrm{Pb}$ e $\mathrm{Sm}-\mathrm{Nd}$; procedimento adotado no CPGeo 
de acordo ao procedimento adotado no CPGeo: na galena com $\mathrm{HCl}$, na pirita e esfalerita com $\mathrm{HCl}, \mathrm{HNO}_{3}$ e $\mathrm{HBr}$, e na rocha total com $\mathrm{HF}, \mathrm{HCl}, \mathrm{HNO}_{3}$ e $\mathrm{HBr}$ (Figura 7). Após essa fase continou-se com a separação dos elementos na coluna.

Separação de Elementos: $\mathrm{Na}$ separação do $\mathrm{Pb}$ utilizou-se a coluna de troca iônica usada no CPGeo: AG 1-X8 200-400 mesh chloride form Bio-Rad, O procedimento seguido pode ser observado na Figura 8.

Leitura no espectrômetro: Utilizou-se um espectrômetro VG 354, multicoletor, com analisador de modo estático, filamentos simples de Re, amostra depositada com $\mathrm{H}_{3} \mathrm{PO}_{4}+$ Sílica Gel.

\subsubsection{MÉTODO Sm/Nd}

O Método $\mathrm{Sm} / \mathrm{Nd}$ foi realizado em 7 piritas e 11 amostras (1 amostra para $\mathrm{Nd} / \mathrm{Nd}$ ) de rocha total das encaixantes (Tabela 2). A técnica adotada foi de diluição isotópica, o ataque químico realizou-se com diferentes ácidos até a dissolução da amostra; a separação do Sr foi feita na coluna de troca iônica e o Sm e Nd na coluna de pó de teflón.

Ataque químico: Inicialmente, foram separados de 50 a $100 \mathrm{mg}$ da amostra na balança Toledo (modelo AT 201); a dissolução da amostra foi realizada por repetidos ataques de ácidos $\left(\mathrm{HNO}_{3}, \mathrm{HF}\right.$ e $\left.\mathrm{HCl}\right)$ a diferentes concentrações e quantidades (Figura 7).

Separação de elementos: A separação do $\mathrm{Sr}$ e das terras raras realizou-se numa coluna primaria de quartzo de $5 \mathrm{~mm}$ de diâmetro e $180 \mathrm{~mm}$ de altura, preenchida com resina catiônica do tipo AG 50W X8 (200-400 mesh). A maneira geral no procedimento seguiram-se as seguintes etapas: deposição da amostra com adição de $\mathrm{HCl} 2,5 \mathrm{~N}$ repetidas vezes; eluição $\mathrm{com} \mathrm{HCl} 2,5 \mathrm{~N}$; adição de $\mathrm{HCl} 2,5$ com posterior coleta de Sr posteriormente secado na chapa e enviado para leitura no espectrômetro; adição de $\mathrm{HCl}$ 2,5 $\mathrm{N}$ com posterior coleta das terras raras que são secadas e enviadas para a coluna de pó de teflón; finalmente regeneração da resina com $\mathrm{HCl} 6 \mathrm{~N}$ (Figura 9). 


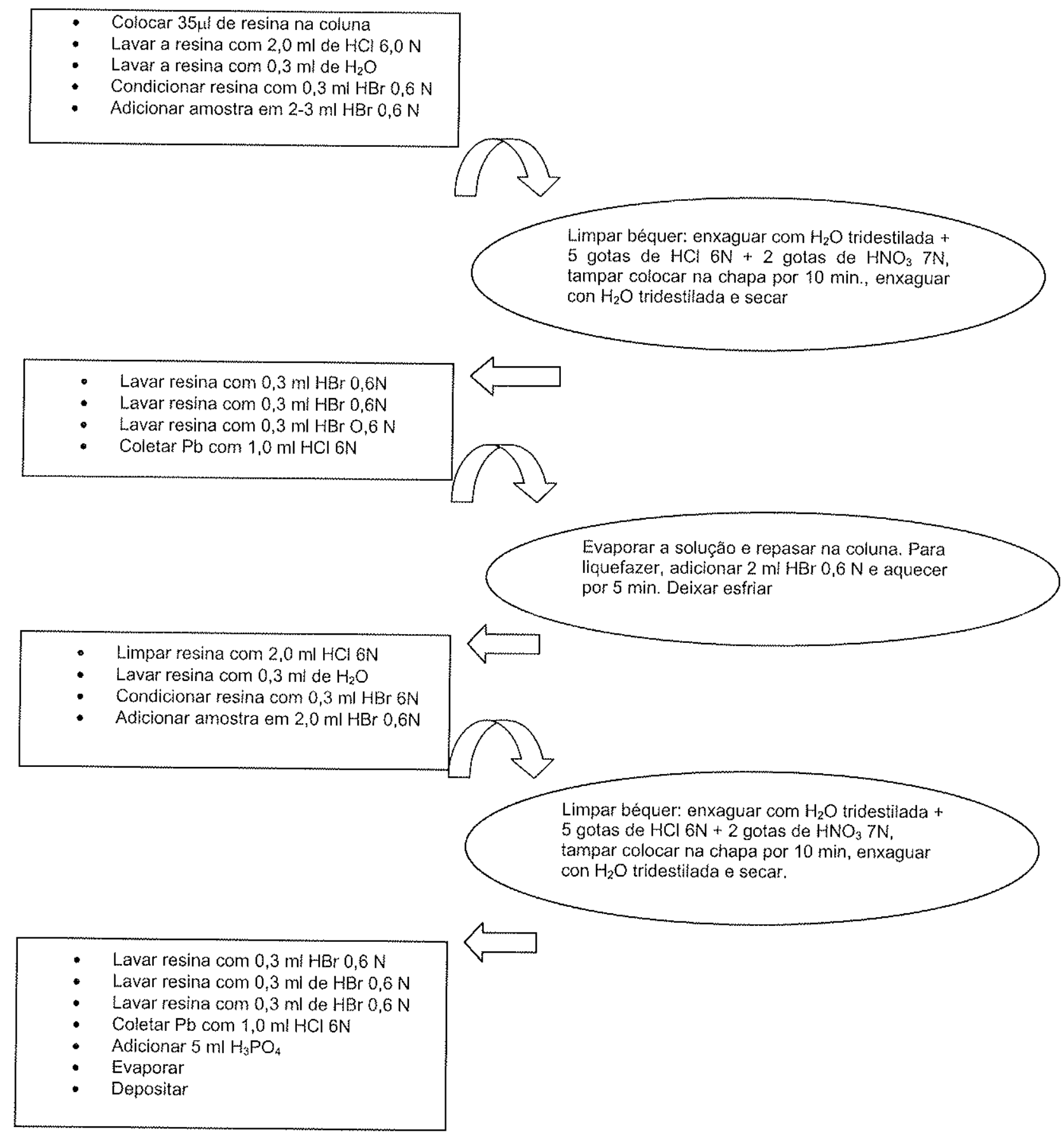

Figura 8. Separação do $\mathrm{Pb}$, procedimento adotado no CPGeo 


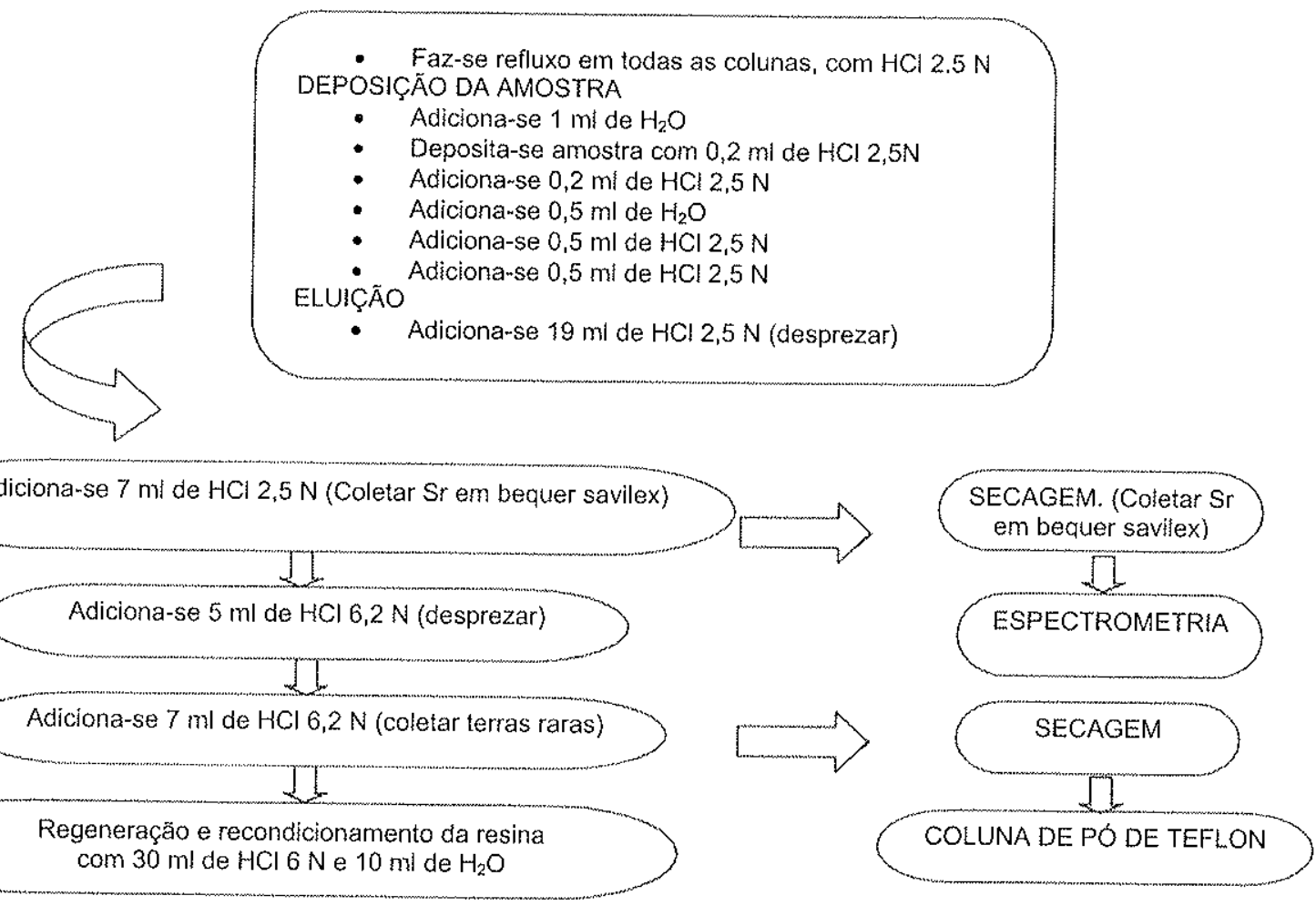

Figura 9. Separação de terras raras e coleta de Sr, procedimento adotado no CPGeo.
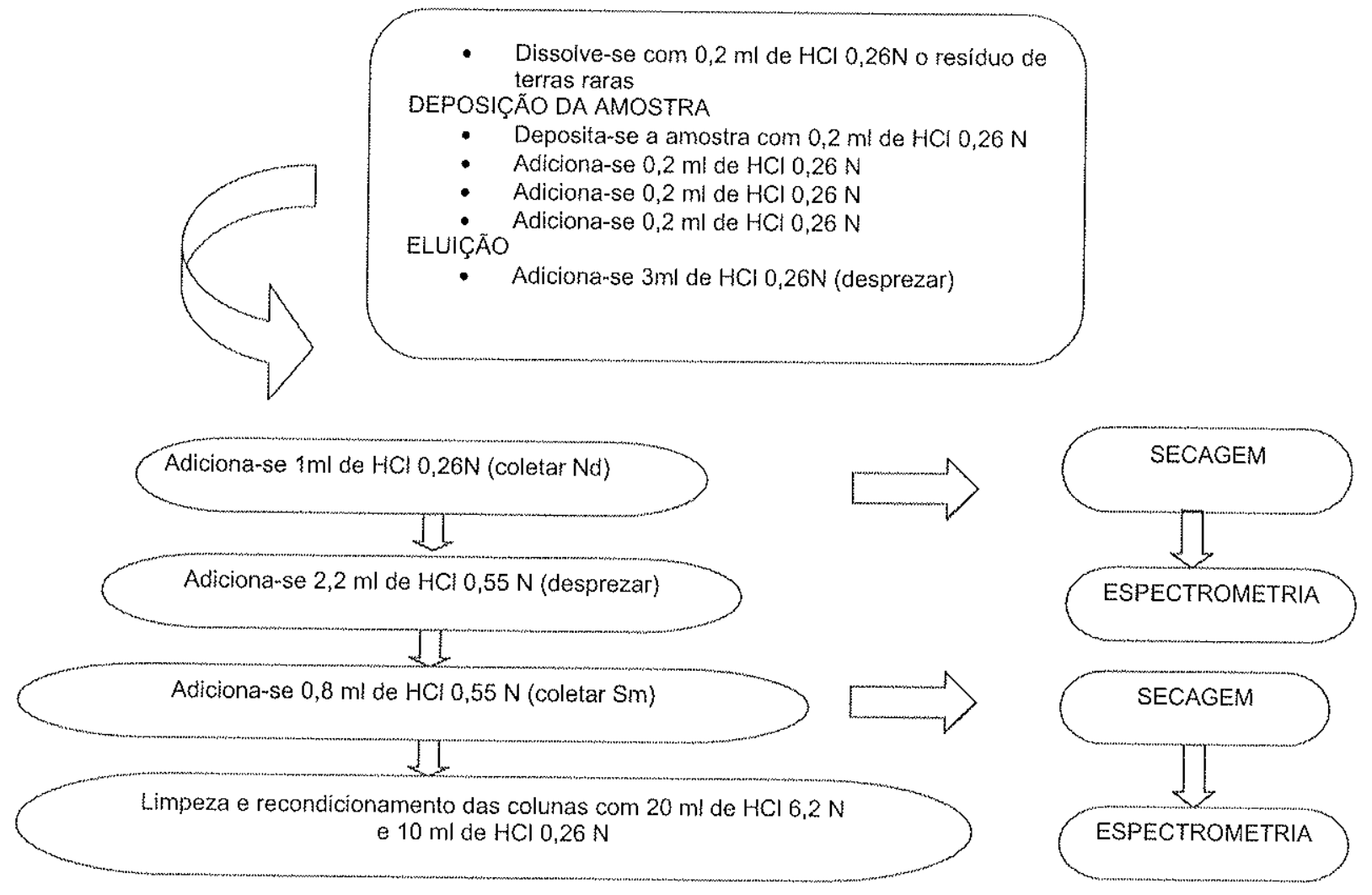

Figura 10. Coleta de Sm e Nd na coluna de teflón, procedimento adotado no CPgeo 
Para a separação de $\mathrm{Sm}$ e de $\mathrm{Nd}$, utilizou-se uma coluna de quartzo com diâmetro de $5 \mathrm{~mm}$ e altura de $100 \mathrm{~mm}$, preenchida com pó de teflón (200 mesh) previamente tratado com ácido Di (2-etilexil) fosfórico. De forma geral no procedimento seguiram-se as seguintes etapas: dissolução da amostra com $\mathrm{HCl} 0,26 \mathrm{~N}$; deposição da amostra com adição repetidas vezes de $\mathrm{HCl} 0,26 \mathrm{~N}$; eluição com $\mathrm{HCl} 0,26 \mathrm{~N}$; adição de $\mathrm{HCl} 0,26 \mathrm{~N}$ seguido de coleta de $\mathrm{Nd}$ posteriormente secado na chapa e enviado a leitura no espectrômetro; adição de $\mathrm{HCl}$ 0,26 N e coleta de $\mathrm{Sm}$ posteriormente secado na chapa e enviado a leitura no espectrômetro; finalmente recondicionamento das colunas com $\mathrm{HCl}$ 6,2 $\mathrm{N}$ (Figura 10).

Leitura no espectrômetro: Utilizou-se um espectrômetro tipo Mass Spectrometer Model 262, multicoletor, com analisador modo estático, com filamento de duplo Re, amostra depositada com $\mathrm{H}_{3} \mathrm{PO}_{4}$ diluído.

\subsubsection{MÉTODO K-Ar}

O método K-Ar foi aplicado na datação da amostra FHD-24, localizada no setor Marmato bajo, a rocha consiste de um pórfiro dacítico afetado por alteração propilítica e fílica (Tabelas 1 e 2). O procedimento adotado no ataque químico e na leitura de $\mathrm{K}$, é apresentado na Figura 11.

A extração do Ar da amostra se processa em sistema de extração de alto-ultra vácuo; a fusão da amostra é realizada com pressões da ordem de $10^{-8} \mathrm{mmHg}$, diminuindo o branco de ${ }^{40} \mathrm{Ar}$ a aproximadamente $2 \times 10^{-12}$ moles, 1000 vezes menor que o conteúdo de ${ }^{40} \mathrm{Ar}$ na amostra analisada; o procedimento e descrito a seguir: 1) $A$ amostra é colocada dentro de um cadinho de molibdênio, colocado dentro de uma garrafa de vidro pyrex, conectada ao sistema de purificação. 2) A fusão da amostra se efetua por intermedio de um forno de indução. 3) Os gases liberados são misturados com quantidades medidas de gás traçador (spike de ${ }^{38} \mathrm{Ar}$ ). 4) A mistura de gases é purificada por exposição à ação de $\mathrm{Cu}-\mathrm{CuO}$ a quente $\left(450^{\circ} \mathrm{C}\right.$, forno de $\left.\mathrm{Cu}-\mathrm{CuO}\right)$ e a um agente secante, zeolitas, responsáveis pela eliminação de $\mathrm{CO}_{2}$ e $\mathrm{H}_{2} \mathrm{O}$; posteriormente, ao Ti a quente $\left(800^{\circ} \mathrm{C}\right.$, forno de titânio) com função de absorver todos os demais gases $\left(\mathrm{N}_{2}, \mathrm{O}_{2}\right.$ e $\left.\mathrm{H}_{2}\right)$. 5) A manipulação dos gases é feita por intermédio de carvão ativado, 
esfriado a temperatura do nitrogênio liquido $\left(-195^{\circ} \mathrm{C}\right)$. 6) A amostra é recolhida em coletor porta-amostra que é selado com maçarico e transferido ao espectrômetro de massa (Thomaz-Filho e Torquato, 1974).

Nas análises isotópicas de Ar purificado, o espectrômetro de Massa é do tipo MS-1, com fonte iônica tipo "NiER", com angulo de deflexão de $60^{\circ}$, focalização simples, de 52,07 cm (41/2)" de raio de curvatura, é fabricado com vidro pyrex e utiliza um detetor Faraday. $\mathrm{O}$ espectrômetro e o sistema de amostras são bombeados com bombas "VAC-ION" .

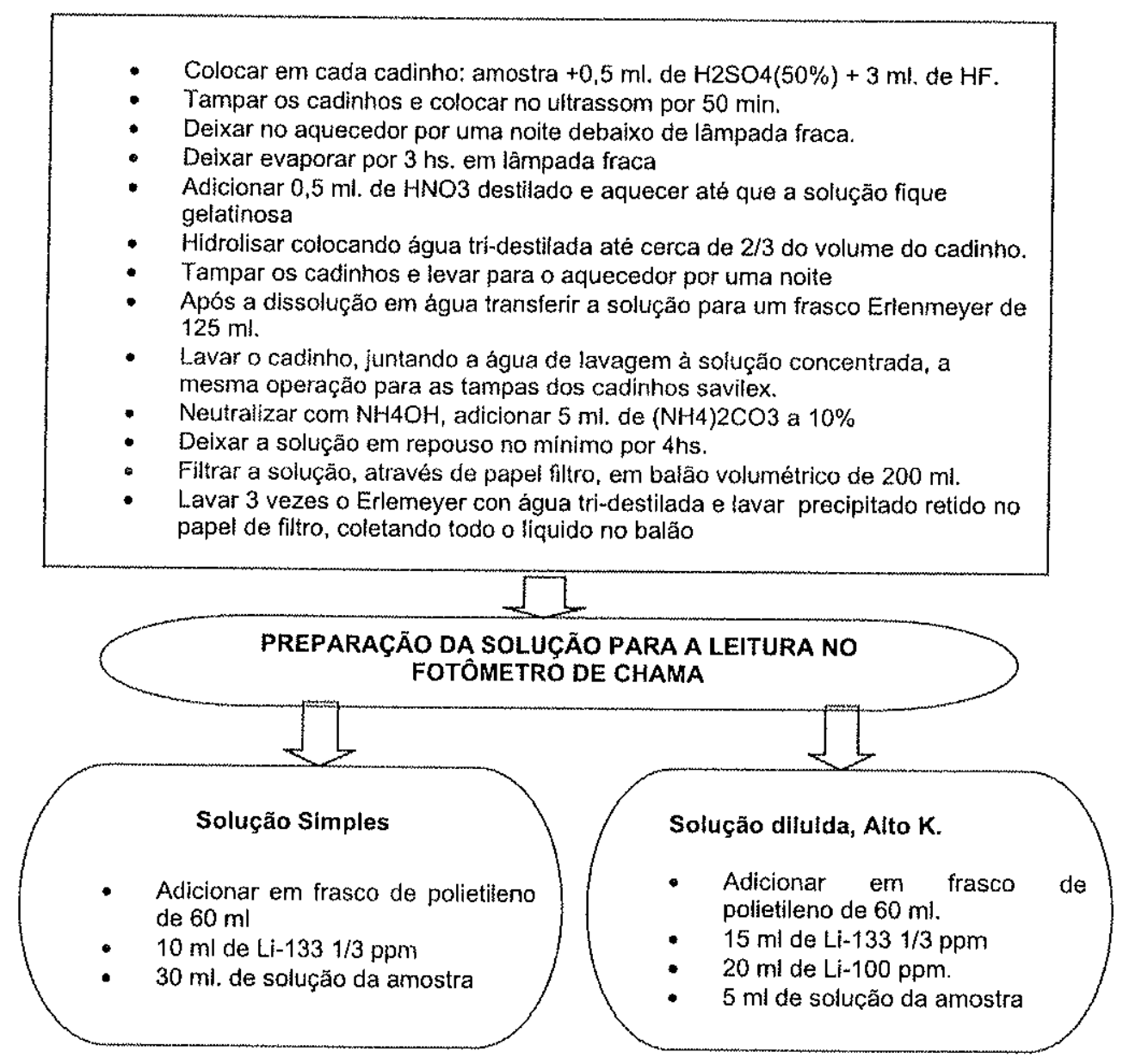

Figura 11. Procedimento adotado no CPGeo, no ataque químico e leitura do Potássio no fotômetro 


\subsection{ANALISES DE DADOS E INTERPRETAÇÃO DE RESULTADOS}

A interpretação dos resultados isotópicos foi realizado através de diagramas de $\varepsilon_{\mathrm{Nd}} \times{ }^{87} \mathrm{Sr} /{ }^{86} \mathrm{Sr}$ e para as razões de $\mathrm{Pb} / \mathrm{Pb}$, de diagramas dos modelos da plumbotectônica. Os valores obtidos nas análises isotópicas das razões $\mathrm{Sr} / \mathrm{Sr}$, Sm/Nd e $\mathrm{Pb} / \mathrm{Pb}$, para as mineralização e para as rochas encaixantes, foram comparados para fazer inferências sobre a fonte dos fluidos.

$\mathrm{Na}$ interpretação dos resultados da lixiviação em esfalerita, utilizou-se o programa isoplot, e foi feita uma caracterização mineralógica no MEV do material de preenchimento e dos microcristais inclusos na esfalerirta. No caso da datação pelo método K-Ar em plagioclásio alterado hidrotermalmente, a interpretação foi feita de acordo aos resultados analíticos e a sua descrição petrográfica. 


\section{CONCEITOS TEÓRICOS}

Neste cápitulo será apresentada uma revisão dos conceitos teóricos dos métodos isotópicos usados; baseados principalmente em: Dickin (1995), Faure (1986), DePaolo (1988) e Zartman e Doe (1981).

\subsection{GENERALIDADES}

Os átomos são constituídos, de uma forma geral, por prótons, nêutrons e elétrons. Os prótons e nêutrons estão no núcleo, onde ocorrem as reações nucleares; os elétrons o rodeiam em níveis de energia e são os responsáveis pelas reações químicas. O número de prótons é denominado número atômico (Z). Átomos com o mesmo $Z$ pertencem ao mesmo elemento químico; o número de nêutrons é denominado como $(\mathbf{N})$; e a soma dos dois $(Z+N)$ é a massa atômica $(\mathbf{A})$. As partículas atômicas fundamentais são os Nuclídeos, que se caracterizam por possuir $Z, N$ e A, características que permitem sua diferenciação de outras particulas; os Isótopos de um mesmo elemento são átomos com igual $Z$ mais diferente $A$.

Os prótons e nêutrons encontram-se no núcleo do átomo ligados por forças nucleares, a estabilidade do átomo depende do equilibrio entre o número de prótons e nêutrons. Os átomos com massa atômica baixa, possuem similar número de prótons e nêutrons $(\mathrm{N}=\mathrm{Z})$ e seus núcleos são estáveis; mais ao aumentar a $A$, o número de prótons e nêutrons pode variar e o núcleo torna-se mais instável ( $N / Z=1.5$ ) (Dickin, 1995).

\subsubsection{Decaimento Radioativo}

A radioatividade é uma propriedade dos átomos, na qual os átomos instáveis ou radiativos, denominados geralmente como átomos $P$ ai $(\mathbf{P})$, são transformados para formas estáveis ou átomos radiogênicos denominado Filhos (F). A radioatividade, também é definida como a emissão espontânea de partículas alfa( $\alpha)$, beta $\left(\beta^{+}, \beta^{-}\right)$, ou 
radiações eletromagnéticas; ou como a probabilidade de uma partícula nuclear escapar através de uma barreira de potencial que a vincula ao núcleo. A captura eletrônica $\mathrm{K}$ ou $L$ considera-se um tipo especial de radioatividade.

A transmutação Alfa $(\sigma)$ assemelha-se à perda de um átomo de Hélio pelo elemento, no processo libera-se energia $\left(\mathbf{Q}_{\alpha}\right)$. Quando um radionuclídeo emite uma partícula alfa, seu número de massa diminui em quatro unidades e seu número atômico em duas. A reação que a representa é:

$$
{ }_{Z}^{A} \mathrm{El} \rightarrow{ }_{\mathrm{Z}-2}^{\mathrm{A}-4} \mathrm{El}+\mathrm{He}^{+2}+\mathrm{Q}_{\alpha}
$$

A transmutação Beta $(\beta)$, caracteriza-se pela perda ou ganho do próton pelo elemento (podendo ser $\beta^{-}$ou $\beta^{+}$), com a liberação de um isóbaro $\left(Q_{B}\right)$ e um Antineutrino $\left(v^{*}\right)$ ou um Neutrino $(U)$. O decaimento $\beta$ é produzido pela transformação de um néutron (n) em um próton (p) ou de um próton em um néutron. Quando um radionuclídeo emite uma partícula Beta seu número de massa permanece constante e seu número atômico aumenta ou diminui em uma unidade. As reações que a representa são mostradas a seguir:

$$
\begin{aligned}
& { }_{\mathrm{z}}^{A} \mathrm{El} \rightarrow{ }_{\mathrm{Z}+1}^{A} \mathrm{El}+\beta^{-}+\mathrm{V}^{-}+\mathrm{Q}_{\mathrm{B}} \\
& { }_{\mathrm{z}}^{\mathrm{E}} \mathrm{El} \rightarrow{ }_{\mathrm{Z}-1}^{A} \mathrm{El}+\beta^{+}+\mathrm{U}_{+} \mathrm{Q}_{\mathrm{B}} \\
& \mathrm{n} \rightarrow \mathrm{p}+\beta^{-}+\mathrm{V}^{-} \\
& \mathrm{p} \rightarrow \mathrm{n}+\beta^{+}+\mathrm{U}
\end{aligned}
$$

As radiações eletromagnéticas, são ondas eletromagnéticas de origem nuclear com comprimento de onda menor do que $10^{-2} \AA$, emitidas em seguida à emissão de uma partícula alfa ou beta, por núcleos excitados que voltam ao estado fundamental. 
A captura eletrônica é produzida em elementos com deficiência em nêutrons, pelo qual um elétron $\left(\mathbf{e}^{*}\right)$ da camada $\mathrm{K}$ ou $\mathrm{L}$ é absorvido pelo núcleo segundo a reação:

$$
p+e^{--} \rightarrow n+u
$$

\subsubsection{Equação fundamental da Geocronologia}

O decaimento radioativo expressa-se matematicamente como o número de nuclídeos radiativos $(\mathbf{d N})$ que decai naturalmente num tempo (dt), sendo proporcional ao número total de átomos ou isótopos radioativos $(\mathbf{N})$, multiplicado pela constante de decaimento radioativo $(\lambda)$. A constante é definida como a probabilidade que tem um nuclídeo radiativo de desintegrasse na unidade de tempo, seu valor não depende da temperatura, pressão ou propriedades químicas. Resolvendo matematicamente chegase à equação fundamental do decaimento radioativo (Apêndice $A .1$ ), onde: $N(t)=$ Número de nuclídeos radioativos não transmutados o $\mathrm{Pai}(\mathrm{P}(\mathrm{t}))$, e $N o=$ Número de nuclidios radiativos originais. A equação mostra-se a seguir:

$$
\frac{\mathrm{dN}}{\mathrm{dt}}=-\lambda \mathrm{N} \stackrel{\text { RESOLVENDO }}{\longrightarrow} \mathrm{N}(\mathrm{t})=\mathrm{N}_{0} \mathrm{e}^{-\lambda t}(1)
$$

Resolvendo matematicamente a equação (1) (Apêndice A.1), e substituindo $N_{0}=$ $P(t)+F(t)$, chega-se à equação fundamental da geocronologia, a qual é expressa como:

$$
\mathrm{No}=\mathrm{P}(\mathrm{t})+\mathrm{F}(\mathrm{t}) \stackrel{\mathrm{EM}(1)}{\longrightarrow} \mathrm{t}=\frac{1}{\lambda}\left(1+\frac{F(t)}{\mathrm{P}(\mathrm{t})}\right)(2) \text { ou } \mathrm{F}(\mathrm{t})=\mathrm{P}(\mathrm{t})\left(\mathrm{e}^{\lambda t}-1\right)(3)
$$

Sendo $t$, a idade ou tempo requerido para a formação dos átomos radiogênicos o filhos $(F(t))$ pelo decaimento dos átomos radiativos de acordo a sua probabilidade de decaimento, $\lambda$. O termo meia vida, $\left(\mathrm{T}_{1 / 2}\right)$, é o tempo necessário para que o número de átomos originais seja reduzido a sua metade $(\mathrm{No} / 2)$. 


\subsubsection{Tipo de idades obtidas}

As idades geocronológicas podem-se dividir em convencionais e isocrônicas: as Idades convencionais são obtidas a partir da equação geral da geocronologia (equação (2)), onde a razão inicial é assumida; as Idades isocrônicas são obtidas através de diagramas isocrônicos (Apêndice A.2) e dividem-se em: 1) Isócrona: obtida através de cálculos, onde a razão isotópica inicial é determinada de um diagrama isocrônico, obtido de amostra cogenéticas. 2) Isócrona de referência: obtida de amostras de diferentes fontes mais que sofreram um evento em comum. 3) Isócrona mineral: obtida nos minerais separados de uma mesma amostra. 4) Errócrona: obtida quando a melhor reta calculada por regressão linear não se alinha dentro dos erros experimentais.

Os diagramas isocrônicos são derivados da equação (3) (Apêndice A.2), é são representados pela seguinte equação:

$$
F(t)=P(t)\left(e^{\lambda t}-1\right) \Rightarrow F_{\text {Hoje }}=F_{\text {inicial }}+P_{\text {Hoje }}\left(e^{\lambda t}-1\right)(\text { equação }(4))
$$

A qual é da forma $Y=Y_{0}+m X$, que é a equação de uma reta e define o diagrama isocrônico, solucionando (Apêndice A.2):

$$
\operatorname{tg} \alpha=\mathrm{m}=\lambda \mathrm{t} \Rightarrow \mathrm{t}=\frac{\operatorname{tg} \alpha}{\lambda}
$$

Onde $m=$ pendente da reta, e $\alpha=$ inclinação da reta.

\subsubsection{Premissas}

- O sistema deve ser fechado em relação à entrada ou saída de elementos Pai o Filho.

- O número de elementos Filho iniciais no sistema deve-se conhecer. 
- O valor da constante de decaimento $\lambda$ deve-se conhecer.

\subsection{SISTEMÁTICA Rb-Sr}

O Rubídio é um metal alcalino que pertence ao grupo I-A, tem número atômico 37 e massa atômica 86; possui dois isótopos ${ }^{85} \mathrm{Rb},{ }^{87} \mathrm{Rb}$ com abundância de $72.17 \%$ e $27.83 \%$ respetivamente. O Sr é um metal alcalino terroso que pertence ao grupo II-A , tem número atômico 38 e massa atômica 87 ; possui quatro isótopos ${ }^{84} \mathrm{Sr},{ }^{86} \mathrm{Sr},{ }^{87} \mathrm{Sr}$, ${ }^{88} \mathrm{Sr}$; com abundância de $0.5580 \%, 9.8610 \%, 6.9934 \%$ e $82.5877 \%$ respectivamente.

$\mathrm{O}{ }^{87} \mathrm{Rb}$ é um Isótopo radiativo que decai para ${ }^{87} \mathrm{Sr}$ com uma constante de desintegração $\lambda=1.42 \times 10^{-10}$ anos, sua meia vida é $T_{1 / 2}=5,6 \times 10^{9}$ anos. Sua reação de decaimento é:

$$
{ }^{87} \mathrm{Rb} \rightarrow{ }^{87} \mathrm{Sr}+\beta^{-}+\mathrm{V}^{-}+\mathrm{Q}
$$

Geoquímicamente o Rb e o Sr fazem parte dos elementos litófilos e devido a seu baixo potencial iônico são moveis, sendo o $\mathrm{Rb}$ enriquecido nas rochas da crosta continental; por isso sua razão $\mathrm{Rb} / \mathrm{Sr}$ é maior na crosta do que no manto. O Rubídio não é formador de minerais, mas por seu raio iônico $(1,48 \AA)$ e suas propriedades químicas similares às do Potássio (Grupo l-A), é possivel sua substituição em minerais ricos em $\mathrm{K}$ como micas (moscovita, biotita, flogopita, lepidolita), feldspato potássico (ortoclásio e microclino), em argilominerais e minerais evaporiticos (silvita e carnalita). $\mathrm{O}$ raio iônico do $\operatorname{Sr}(1,13 \AA)$ é similar ao do Cálcio $(0,99 \AA)$, podendo substituí-lo em minerais como o plagioclásio, apatita e carbonatos; além disso é o cátion principal na estroncianita $\mathrm{SrCO}_{3}$ e na celestita $\mathrm{SrSO}_{4}$.

\subsubsection{Evolução isotópica do Sr na Terra}

No modelo de evolução do Sr, a composição da terra no seu momento de formação, é assumida como a mesma dos meteoritos; e já que os meteoritos não foram afetados por processo geológicos posteriores como as rochas terrestres, suas razões 
isotópicas iniciais corresponderiam as do $\mathrm{Sr}$ primordial da terra. De acordo aos valores do BABI ("Best Achondritic Basaltic Initial"), a razão ${ }^{87} \mathrm{Sr} /{ }^{86} \mathrm{Sr}$ da terra no seu momento de formação, há 4.5 b.a. é de 0.699 (Papanastassiou e Wasserburg, 1969 apud Torquato e Kawashita, 1994).

Devido ao decaimento radiativo do $\mathrm{Rb}$ para $\mathrm{Sr}$, o $\mathrm{Sr}$ radiogênico tem aumentado através do tempo geológico, atualmente a razão ${ }^{87} \mathrm{Sr} /{ }^{86} \mathrm{Sr}$ do manto é de $0.704 \pm 0.002$, de acordo a medições em rochas basálticas e gabros com pouca contaminação crustal. A evolução do Sr no manto, desde seu estado inicial ao atual, é de caráter não linear, devido ao empobrecimento do $\mathrm{Rb}$ no manto, e enriquecimento na crosta por processos de diferenciação manto crosta (Figura 12).

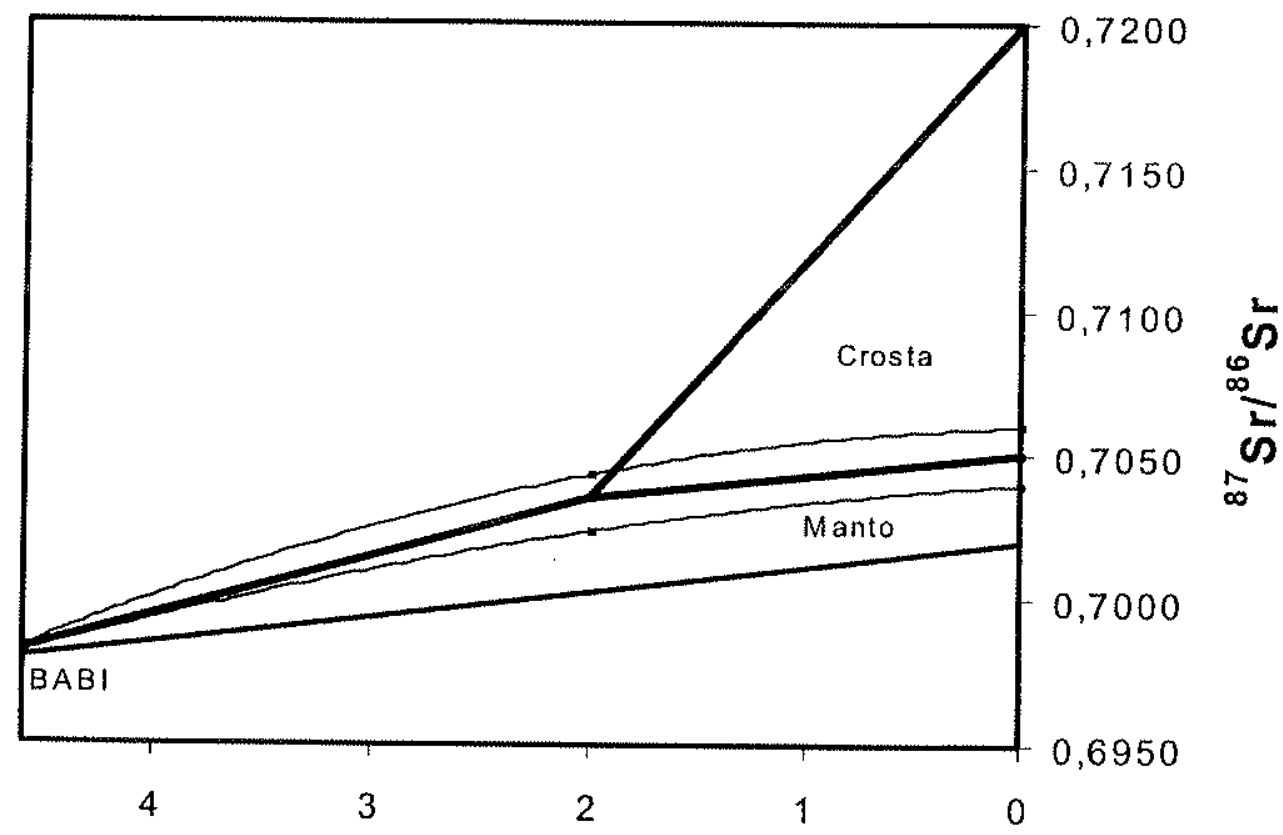

Tempo (Ga)

Figura 12. Evolução do Sr na terra.

Essas diferenças nas razões ${ }^{87} \mathrm{Sr} /{ }^{86} \mathrm{Sr}$ entre o manto e a crosta, são usadas como um parâmetro petrogenêtico importante, para a determinação da fonte dos 
magmas; os magmas derivados do manto atualmente apresentam em geral razões menores o iguais a 0.706 , e as derivadas da crosta valores mais altos, devido ao enriquecimento de Rubídio na crosta.

Medidas feitas em diferentes tipos de rochas vulcânicas basálticas, apresentam variações nas sua razões ${ }^{87} \mathrm{Sr} /{ }^{86} \mathrm{Sr}$ em função dos diferentes graus de contaminação crustal, na Tabela 3, apresenta-se alguns delas:

Tabela 3. Valores da razão ${ }^{87} \mathrm{Sr} /{ }^{86} \mathrm{Sr}$, para alguns tipos de rochas (Faure, 1986).

\begin{tabular}{|l|l|}
\hline \multicolumn{1}{|c|}{ Rocha } & ${ }^{87} \mathrm{Sr}^{86} \mathrm{Sr}$ \\
\hline Basaltos de dorsais oceânicas & 0.70280 \\
\hline Arcos de Ilhas oceânicas & 0.70386 \\
\hline Arcos de Ilhas continentais & 0.70437 \\
\hline Áreas Continentais & 0.70577 \\
\hline
\end{tabular}

As rochas derivadas de dorsais oceânicas apresentam baixas razões isotópicas devido a que são originadas no manto superior e têm pouca contaminação crustal; nas rochas vulcânicas derivadas de arcos magmáticos pode existir aporte do Sr radiogênico derivado dos sedimentos e da água do mar absorvida na crosta oceânica em subducção, além da contaminação crustal e o $\mathrm{Sr}$ absorvido pelo magma nas rochas encaixantes durante sua ascensão para níveis mais elevados da crosta continental.

\subsection{SISTEMÁTICA K-Ar}

O Potássio é um elemento do Grupo I-A, pertencente aos metais alcalinos, é um dos oito elementos mais abundantes na crosta terrestre e dos principais constituintes dos minerais. O Potássio tem três isótopos, ${ }^{39} \mathrm{~K},{ }^{40} \mathrm{~K}$ e ${ }^{41} \mathrm{~K}$; com abundância $93.2581 \%$, $0.01167 \%$ e $6.7302 \%$ respetivamente. Por sua parte o Argônio tem três isótopos ${ }^{40} \mathrm{Ar}$, ${ }^{38} \mathrm{Ar}$ e ${ }^{36} \mathrm{Ar}$ com abundância de $99.6 \%, 0.063 \%$ e $0.337 \%$ respetivamente. 
O ${ }^{40} \mathrm{~K}$ é um nuclídeo radioativo que decai naturalmente a ${ }^{40} \mathrm{Ar}$ e a ${ }^{40} \mathrm{Ca}$; suas constantes de decaimento são $\lambda_{e}=0.581 \times 10^{-10}$ anos, e $\lambda_{B}=4.962 \times 10^{-10}$ anos respetivamente sendo seu $\lambda\left(\lambda_{e}+\lambda_{B}\right)=5.543 \times 10^{-10}$ anos; e sua $T_{1 / 2}=1.250 \times 10^{9}$ anos. $A$ reação que representa seu decaimento é:

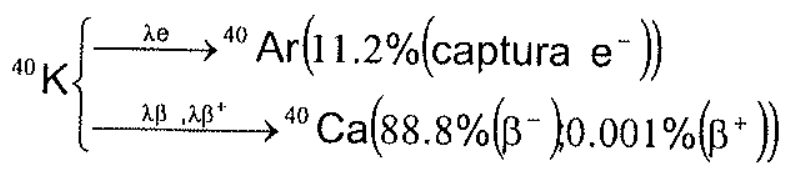

A idade K-Ar, é obtida tomando como base a equação fundamental da geocronologia (2):

$$
\mathrm{t}=\frac{1}{\lambda} \ln \left(1+\frac{\mathrm{F}(\mathrm{t})}{\mathrm{P}(\mathrm{t})}\right)
$$

Resolvendo para o decaimento ${ }^{40} \mathrm{~K}, \operatorname{com} \lambda=\lambda \mathrm{e}+\lambda \beta$ (Apêndice, $\mathrm{A} 3$ ):

$$
t=1.804 \times 10^{9} \ln \left(1+9.54 \frac{{ }^{40} \mathrm{Ar}}{{ }^{40} \mathrm{~K}}\right)(5)
$$

Onde t, é o tempo do decaimento para a formação do ${ }^{40} \mathrm{Ar}$, dos átomos pais de ${ }^{40} \mathrm{~K}$, de acordo às constantes de decaimento do ${ }^{40} \mathrm{Ca}$ e ${ }^{40} \mathrm{Ar}\left(\lambda \mathrm{e}, \lambda \beta^{-}\right)$.

A idade terá significado se são satisfeitas as seguintes premissas: 1) Não tem perda de ${ }^{40} \mathrm{Ar}$ radiogênico. 2) $\mathrm{O}$ mineral permaneceu fechado para a entrada de ${ }^{40} \mathrm{Ar}$ radiogênico externo, após sua formação. 3) Foi feita uma apropriada correção do ${ }^{40} \mathrm{Ar}$ atmosférico. 4) O mineral permaneceu fechado em relação ao K. 5) A composição isotópica do $\mathrm{K}$ não mudou, exceto pelo decaimento do ${ }^{40} \mathrm{~K}$.

O Potássio, pelas suas características químicas é um elemento móvel; acumulase nos estados finais dos processos magmáticos e sua concentração é maior nas rochas da crosta superior. O Ar, é um gás nobre e não apresenta reações químicas, acumula-se na atmosfera.

No decaimento do $\mathrm{K}$ ao $\mathrm{Ar}$, o Ar é retido na estrutura cristalina do mineral, por aumento de temperatura a estrutura pode-se afeitar e o Ar pode escapar, a temperatura 
em que isto ocorre é conhecida como temperatura critica. A idade K-Ar, é interpretada como idade de resfriamento, na qual o mineral alcançou a sua temperatura critica de fechamento.

\subsection{SISTEMÁTICA Sm-Nd}

O Sm e o Nd são elementos do grupo das terras raras (Grupo III-B), subgrupo dos lantánidos. O Samário tem número atômico 62 e massa atômica 150.4, possui sete isótopos: ${ }^{144} \mathrm{Sm},{ }^{147} \mathrm{Sm},{ }^{148} \mathrm{Sm},{ }^{149} \mathrm{Sm},{ }^{150} \mathrm{Sm},{ }^{152} \mathrm{Sm}$ e ${ }^{154} \mathrm{Sm}$. O Neodímio têm número atômico 60 e massa atômica 144.2 , possui sete isótopos ${ }^{142} \mathrm{Nd},{ }^{143} \mathrm{Nd},{ }^{144} \mathrm{Nd},{ }^{145} \mathrm{Nd}$, ${ }^{146} \mathrm{Nd},{ }^{148} \mathrm{Nd} e{ }^{150} \mathrm{Nd}$.

O ${ }^{147} \mathrm{Sm}$ é radiativo e decai naturalmente para ${ }^{143} \mathrm{Nd}$ com uma constante de desintegração $\lambda=6.54 \times 10^{-12}$ anos, e uma meia vida $T_{1 / 2}$ de $1.06 \times 10^{11}$ anos. Sua reação de decaimento é expressa como:

$$
{ }^{147} \mathrm{Sm} \rightarrow{ }^{143} \mathrm{Nd}+\sigma+\mathrm{Q}
$$

Os lantánidos são em geral geoquímicamente pouco móveis, devido a seu alto potencial iônico: Alta carga $(+3)$ e baixos rádios iônicos de $0.93 \AA$ no La, até $1.15 \AA$ no Lu.

O Sm e o Nd são elementos isoquímicos nos diferentes processos geológicos, mas o Nd tem potencial iônico um pouco menor, devido a que seu raio iônico $(1.08 \AA)$ é pouco maior do que o $\mathrm{Sm}^{+3}(1.04 \AA)$, por isso suas ligações químicas são mais fracas o que torna o elemento um pouco mais móvel. Nos processos de diferenciação mantocrosta o Nd tende a acumularmse na crosta e o Sm permanece no manto, sendo pelo tanto a razão $\mathrm{Sm} / \mathrm{Nd}$ maior no manto do que na crosta.

Nos processos de cristalização de minerais o Samário e o Neodímio concentramse nos minerais dos estágios finais da serie de Bowen: biotitas> hormblenda>piroxenio>olivina ou feldspato potássico>plagioclasio cálcico; outros minerais com alta concentração de Sm e Nd são: Fosfatos, apatitas, monazitas. A razão 
$\mathrm{Sm} / \mathrm{Nd}$ não apresenta grandes variações nos minerais, geralmente de 0.1 até 0.5 : Granada: 0.54; piroxenio: 0.37; feldspato potássico: 0.15 (Faure, 1986)

\subsubsection{Modelo de Evolução isotópico do Nd}

A evolução isotópica do $\mathrm{Nd}$, tem sido dependente do aumento do $\mathrm{Nd}$ radiogênico desde seu estado primordial no momento de formação da terra, até hoje, devido ao decaimento do ${ }^{147} \mathrm{Sm}$ a ${ }^{143} \mathrm{Nd}$. O aumento da razão ${ }^{143} \mathrm{Nd} /{ }^{144} \mathrm{Nd}$ como dependente do tempo, pode-se representar num "Modelo" baseado na idade da terra, a razão in icial ${ }^{143} \mathrm{Nd} /{ }^{144} \mathrm{Nd}$ e ${ }^{147} \mathrm{Sm} /{ }^{144} \mathrm{Nd}$ da terra, analises feitas nos meteoritos permitem conhecer esses valores (Faure, 1986).

De Paolo e Wasserburg (1976), propuseram o modelo chamado "CHUR" ("Chondritic Uniform Reservoir"), para descrever a evolução isotópica do Nd. Esse modelo assume que o Neodímio terrestre tem evoluído de um reservatório uniforme no qual a razão $\mathrm{Sm} / \mathrm{Nd}$ é igual à dos meteoritos condríticos. O valor presente da razão ${ }^{143} \mathrm{Nd} /{ }^{144} \mathrm{Nd}$ deste reservatório e a sua razão ${ }^{147} \mathrm{Sm} /{ }^{143} \mathrm{Nd}$ são:

$$
\frac{{ }^{147} \mathrm{Sm}}{{ }^{144} \mathrm{Nd}}=0.1967 \text { e } \frac{{ }^{143} \mathrm{Nd}}{{ }^{144} \mathrm{Nd}}=0.512638
$$

O modelo permite calcular a razão ${ }^{143} \mathrm{Nd} /{ }^{144} \mathrm{Nd}$ do "CHUR" para qualquer tempo (t), (Apêndice A.4), de acordo à seguinte equação:

$$
\left(\frac{{ }^{143} \mathrm{Nd}}{{ }^{144} \mathrm{Nd}}\right)_{\text {CHUR }}^{t}=\left(\frac{{ }^{143} \mathrm{Nd}}{{ }^{144} \mathrm{Nd}}\right)_{\text {CHUR }}^{\text {Hoje }} \ldots\left(\frac{{ }^{147} \mathrm{Sm}}{{ }^{144} \mathrm{Nd}}\right)_{\text {CHUR }}^{\text {Hoje }}\left(\mathrm{e}^{\text {גi }}-1\right) \text { equação(6) }
$$

Nos processos de fusão parcial do "CHUR", os novos magmas tendem a ter menor razão ${ }^{147} \mathrm{Sm} /{ }^{144} \mathrm{Nd}$, e pelo tanto menor ${ }^{143} \mathrm{Nd} /{ }^{144} \mathrm{Nd}$ do que os sólidos residuais, estes últimos são conhecidos como reservatórios empobrecidos, e terão maior razão ${ }^{147} \mathrm{Sm} /{ }^{144} \mathrm{Nd}$ e por tanto maior razão ${ }^{143} \mathrm{Nd} /{ }^{144} \mathrm{Nd}$ do que o manto condrítjco "CHUR". O Modelo do "CHUR" é representado no diagrama da Figura 13. 


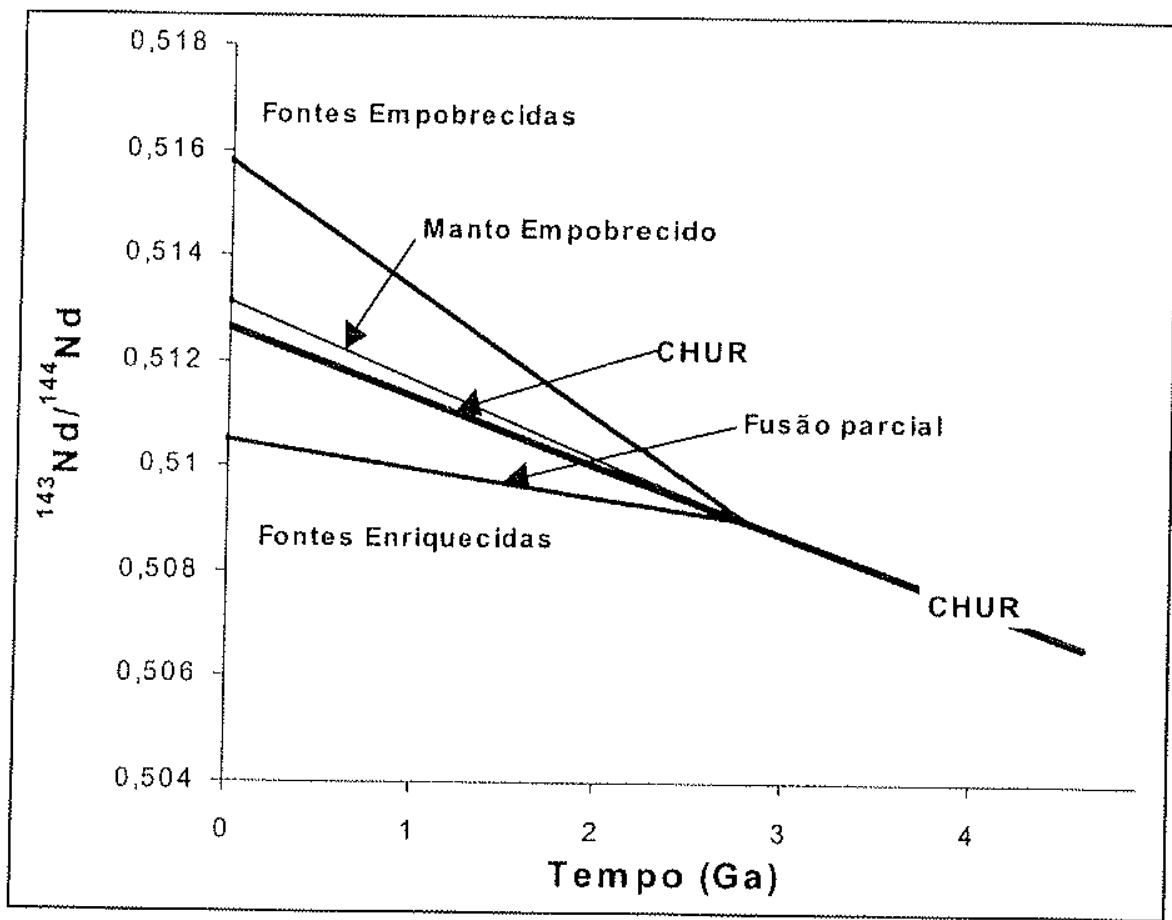

Figura 13. Modelo de Evolução do "CHUR" (De Paolo e Wasserburg, 1976)

\subsubsection{Parâmetro Petrogenêtico $\varepsilon_{N d}$}

A razão ${ }^{143} \mathrm{Nd} /{ }^{144} \mathrm{Nd}$ é um parâmetro petrogenêtico importante, permite diferenciar a possivel fonte do magma. Utiliza-se o parâmetro $\varepsilon_{\mathrm{Nd}}$, definido por DePaolo e Wasserburg (1976), como mostrado na seguinte equação (Apêndice A.4):

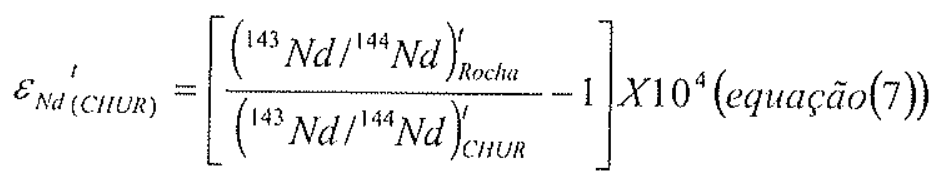

o qual compara a razão ${ }^{143} \mathrm{Nd} /{ }^{144} \mathrm{Nd}$ do "CHUR" com a razão ${ }^{143} \mathrm{Nd} /{ }^{144} \mathrm{Nd}$ da amostra a analisar, sendo o valor de $\varepsilon_{\mathrm{Nd}}$ positivo para rochas derivadas de reservatório mantélico empobrecido e de valor negativo para fontes magmáticas derivadas da crosta (Faure, 1986). 


\subsubsection{Idades Modelos}

As idades modelos indicam o tempo no qual o magma foi diferenciado do reservatório condrítico ou mantélico, segundo o modelo de evolução do Neodímio "CHUR". A premissa para sua determinação (Apêndice A.4), é assumir que no momento da derivação do reservatório condrítico as razões isotópicas $\left({ }^{143} \mathrm{Nd} /{ }^{144} \mathrm{Nd}\right)$ da rocha e do "CHUR" eram iguais, a equação para sua determinação e:

$$
t=\frac{1}{\lambda} \ln \left[\frac{\left(\frac{{ }^{143} \mathrm{Nd}}{{ }^{144} \mathrm{Nd}}\right)_{\text {Rocha }}^{\text {Hoje }}-\left(\frac{{ }^{143} \mathrm{Nd}}{144 \mathrm{Nd}}\right)_{\text {CHUR }}^{\text {Hoje }}}{\left(\frac{{ }^{147} \mathrm{Sm}}{{ }^{144} \mathrm{Nd}}\right)_{\text {Rocha }}^{\text {1ioje }}-\left(\frac{{ }^{147} \mathrm{Sm}}{{ }^{144} \mathrm{Nd}}\right)_{\text {CHUR }}^{\text {Hoje }}}+1\right](\text { equação(8)) }
$$

A idade modelo terá significado, só se a razão ${ }^{147} \mathrm{Sm} /{ }^{144} \mathrm{Nd}$, não se modificou desde a separação do $\mathrm{Nd}$ do reservatório condrítico. A razão ${ }^{147} \mathrm{Sm} /{ }^{144} \mathrm{Nd}$, não muda nos processos de metamorfismo, erosão e meteorização (Faure, 1986).

\subsection{SISTEMÁTICA Pb-Pb}

O Urânio e o Tório são membros da serie dos elementos actínidos. O Urânio tem número atômico 92 e massa atômica 238.0, possui três isótopos ${ }^{238} U,{ }^{235} U,{ }^{234} U$; todos radiativos e com abundância de $99.2743 \%, 0.72 \%$ e $0.0057 \%$ respetivamente. O Tório tem número atômico 90 e massa atômica 232, é conformado por um só isótopo radiativo, o ${ }^{232} \mathrm{Th}$; mais tem cinco isótopos de vida intermedia derivados do decaimento do ${ }^{238} \mathrm{U},{ }^{235} \mathrm{U}, \mathrm{e}^{232} \mathrm{Th} . \mathrm{O}{ }^{234} \mathrm{U}$ é um filho intermediário no decaimento do ${ }^{238} \mathrm{U}$. O Pb tem número atômico 82 e massa atômica 207.7, possui três isótopos radiogênicos, ${ }^{206} \mathrm{~Pb}$, ${ }^{207} \mathrm{~Pb} e^{208} \mathrm{~Pb}$. Nas seguintes reaçōes apresenta se o decaimento do U-Th ao $\mathrm{Pb}$ : 


$$
\begin{aligned}
& { }^{238} \mathrm{U} \rightarrow{ }^{206} \mathrm{~Pb}+8^{4} \mathrm{He}+6 \beta^{-}+\mathrm{Q} \\
& { }^{235} \mathrm{U} \rightarrow{ }^{207} \mathrm{~Pb}+7^{4} \mathrm{He}+4 \beta^{-}+\mathrm{Q} \\
& { }^{232} \mathrm{Th} \rightarrow{ }^{208} \mathrm{~Pb}+6^{4} \mathrm{He}+4 \beta^{-}+\mathrm{Q}
\end{aligned}
$$

Seus valores de $T_{1 / 2}$ e $\lambda$ são:

Tabela 4. Valores de $T_{1 / 2}$ e $\lambda$ para o $U$ e Th (Faure, 1986)

\begin{tabular}{|c|l|l|}
\hline Isótopo & \multicolumn{1}{|c|}{$T_{1 / 2}$} & $\lambda$ \\
\hline${ }^{238} \mathrm{U}$ & $4.468 \times 10^{9}$ anos & $1.55125 \times 10^{-10}$ \\
\hline${ }^{235} \mathrm{U}$ & $0.7038 \times 10^{9}$ anos & $9.848 \times 10^{-10}$ \\
\hline${ }^{234} \mathrm{U}$ & $0.0057 \times 10^{5}$ anos & $2.806 \times 10^{-6}$ \\
\hline${ }^{232} \mathrm{Th}$ & $14.010 \times 10^{9}$ anos & $4.9475 \times 10^{-11}$ \\
\hline
\end{tabular}

Pela configuração eletrônica similar do $U$ e o Th, os dois têm propriedades químicas similares; têm estado tetravalente de oxidação $\mathrm{U}^{+4}$ e $\mathrm{Th}^{+4} \mathrm{com}$ raios iônicos de $1.05 \AA$ e $1.10 \AA$ respetivamente, podendo substituir-se mutuamente e sendo afins geoquímicamente. Mas o $\mathrm{U}$ em condições oxidantes forma o Ion "Uranyl" $\left(\mathrm{UO}_{2}\right)^{+2} \mathrm{com}$ valência + 6, o qual forma componentes solúveis na água; portanto em condições oxidantes o Ion $U$ é mais solúvel e separa-se do Ion Th tetravalente.

Nos processos de fusão parcial e cristalização fracionada o U e o Th são concentrados na fase liquida e incorporados nos produtos silicáticos; sendo as rochas graniticas enriquecidas em $U$ e Th comparadas com as rochas basálticas e ultramáficas. Nos processos de diferenciação geoquímica do manto superior, o U e o Th são concentrados nas rochas da crosta continental. 


\subsubsection{Modelo de Evolução do Pb}

$\mathrm{O} \mathrm{Pb}$ encontra-se distribuido amplamente na terra; como $\mathrm{Pb}$ radiogênico em minerais de rochas antigas com alto U-Th, como $\mathrm{Pb}$ comum em minerais onde é constituinte principal como a galena, e como elemento traço nos diferentes tipos de rochas. A razão isotópica do $\mathrm{Pb}$ é um registro químico dos diferentes ambientes onde residiu, e da sua historia geológica. A composição isotópica do $\mathrm{Pb}$ na terra, tem evoluído, desde seu estágio primordial até hoje, pelo decaimento do U-Th, e pelos processos geológicos que modificaram as razões $\mathrm{U} / \mathrm{Pb}$ e Th/Pb ou misturaram as composições isotópicas do $\mathrm{Pb}$ das diferentes fontes.

A primeira construção de um modelo quantitativo da evolução do $\mathrm{Pb}$ na terra foi feita independentemente por Holmes e Houtermans (apud Faure, 1986), é conhecido como Modelo de Simples Estágio. O modelo assume que a composição isotópica de um mineral com $\mathrm{Pb}$ "comum", como a galena, é o resultado de uma evolução em simplesestagio desde o reservatório isotópico até a formação do mineral. A composição final será o resultado da soma do $\mathrm{Pb}$ primordial mais o $\mathrm{Pb}$ radiogênico formado na fonte pelo decaimento radioativo do $U$ e Th. Patterson (apud Faure, 1986), utilizou este modelo para determinar a idade da terra, com dados de meteoritos construiu uma isócrona obtendo uma idade de $4.55 \pm 0.05 \mathrm{Ga}$. Tatsamoto et al. (apud Faure, 1986) determinou a composição primordial da terra com dados isotópicos de $\mathrm{Pb}$ em troilitas, obtendo valores de ${ }^{206} \mathrm{~Pb} /{ }^{204} \mathrm{~Pb}=9.307 \mathrm{e}{ }^{207} \mathrm{~Pb} /{ }^{204} \mathrm{~Pb}=10.2294$.

\subsubsection{Evolução Duplo-Estágio, Stacey e Kramers}

A discrepância de idades radiogênicas obtidas por outros métodos com as obtidas pelo método de Simples Estágio para vários depósitos minerais, e o excesso do $\mathrm{Pb}$ radiogênico encontrado em galenas em várias jazidas minerais; tornou-se necessário o estabelecimento de modelos de evolução isotópica de $\mathrm{Pb}$ em multiestágios.

Stacey e Kramers (1975), propuseram uma evolução isotópica do Pb em duploestágio; o qual iniciou com as razões do Pb primordial há 4,57 Ga, mas no tempo t, há 
3.7 Ga a razão $\mathrm{U} / \mathrm{Pb}$ do reservatório foi modificada por diferenciação geoquímica permanecendo até hoje a mesma (Figura 14). Para construir o modelo, Stacey e Kramers (1975), determinaram o valor médio da composição isotópica do $\mathrm{Pb}$ na crosta com base em analises isotópicas de rochas sedimentares e vulcânicas depositadas no mar e isócronas $\mathrm{Pb}-\mathrm{Pb}$ em rochas graníticas antigas (ponto de intercessão das isócronas); e com dados das razões isotópicas do $\mathrm{Pb}$ para 13 jazidas minerais, obtiveram os seguintes valores:

Tabela 5. Valores derivados por Stacey e Krammer (1975) para o modelo de duplo estágio.

\begin{tabular}{|c|c|c|c|c|c|c|}
\hline Estagio & $\mathrm{T} \times 10^{9}$ & ${ }^{206} \mathrm{~Pb} /{ }^{204} \mathrm{~Pb}$ & ${ }^{207} \mathrm{~Pb} /{ }^{204} \mathrm{~Pb}$ & ${ }^{208} \mathrm{~Pb} /{ }^{204} \mathrm{~Pb}$ & $\mu$ & $\varpi$ \\
\hline $\mathrm{S} 1$ & 4.57 & 9.307 & 10.294 & 29.476 & 7.192 & 32.208 \\
\hline $\mathrm{S} 2$ & 3.7 & 11.152 & 12.918 & 31.230 & 9.735 & 36.837 \\
\hline Hoje & 0 & 18.700 & 15.628 & 38.630 & 9.735 & 36.837 \\
\hline
\end{tabular}

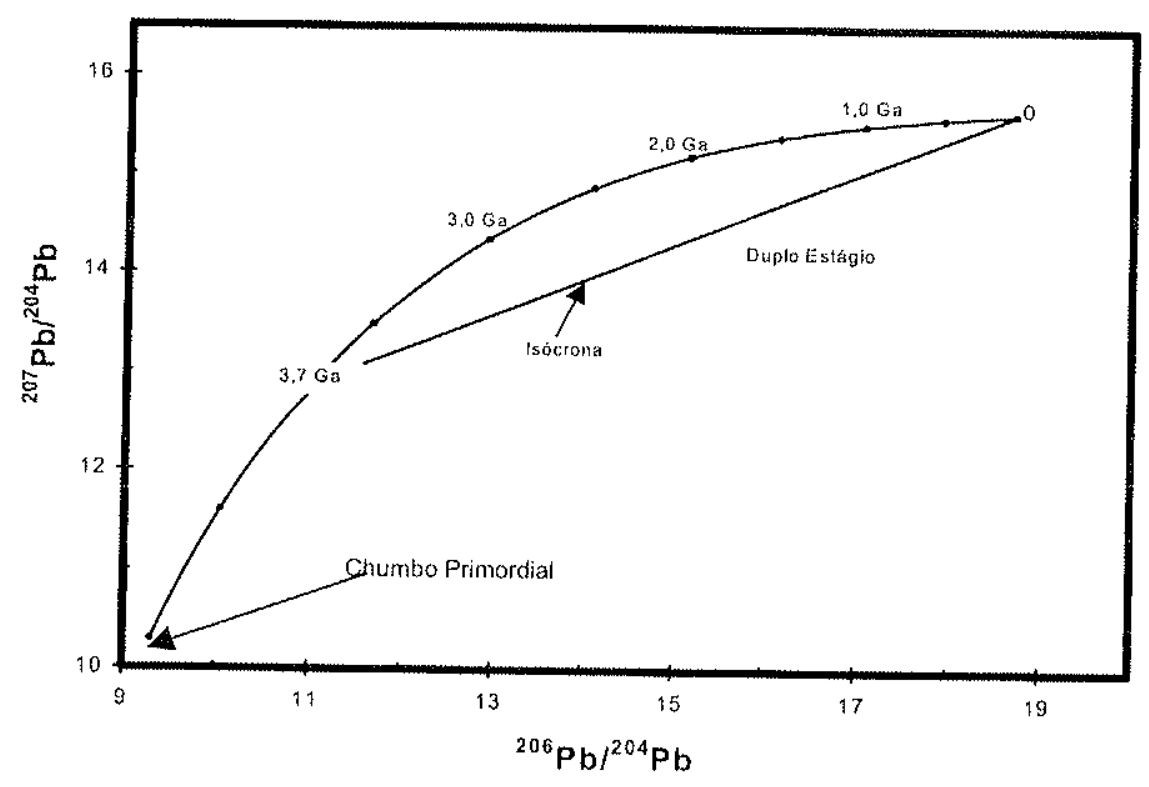

Figura 14. Diagrama de evolução isotópica do $\mathrm{Pb}$ em estágio duplo de Stacey e Kramers (1975) 
O Pb evoluiu neste reservatório até um tempo no passado em que foi separado dele. A equação que calcula o tempo da derivação do $\mathrm{Pb}$ da fonte, de acordo a o duplo estagio é:

$$
\frac{\left(\frac{{ }^{207} \mathrm{~Pb}}{{ }^{204} \mathrm{~Pb}}\right)-12.998}{\left(\frac{{ }^{206} \mathrm{~Pb}}{{ }^{204} \mathrm{~Pb}}\right)-11.152}=\frac{1}{137.88}\left[\frac{\mathrm{e}^{\lambda_{2} \mathrm{~T}^{\prime}}-\mathrm{e}^{\lambda_{2} \mathrm{t}}}{\mathrm{e}^{\lambda_{1} \mathrm{~T}^{\prime}}-\mathrm{e}^{\lambda_{1} \mathrm{t}}}\right](\text { equação }(10))
$$

onde

$$
T^{\prime}=3.7 \times 10^{9} \text { anos. }
$$

Esta equação é transcendental e não tem solução, por isto o valor de t, deve-se determinar com ajuda de uma tabela.

A idade obtida pelo método do duplo estágio terá um significado, se: 1) $\mathrm{OPb}$ evoluiu em um reservatório uniforme entre 4.57 até $3.7 \mathrm{Ga}$, com os valores mostrados na tabela 5. 2) Faz 3.7 Ga os valores do reservatório foram modificados por diferenciação química e permanecem os mesmos até hoje. 3) O $\mathrm{Pb}$ foi removido do reservatório num tempo $\mathrm{t}$, sendo depois incorporado no mineral como $\mathrm{Pb}$ "comum". 4) Após a separação do reservatório, a razão isotópica não tem sido modificados por misturas com outros $\mathrm{Pb}$ ou por adição de $\mathrm{Pb}$ radiogênico.

\subsubsection{Modelo da plumbotectônica}

O modelo da Plumbotectônica foi desenvolvido por Zartman e Doe (1981). Neste modelo, a terra é dividida em três grandes reservatórios de $U$, Th e $\mathrm{Pb}$ : a crosta superior, possui alta razão $\mathrm{U} / \mathrm{Pb}$ e predomina o $\mathrm{Pb}$ radiogênico; na crosta inferior a razão U/Pb é baixa, sendo o $\mathrm{Pb}$ dominante não radiogênico e no manto com uma razão $\mathrm{U} / \mathrm{Pb}$ intermedia sendo o $\mathrm{Pb}$ radiogênico predominante. 
Para a Plumbotectônica a orogênese é um processo geológico onde ocorre transferencia de material entre os três reservatórios, ocasionando uma mistura química e isotópica entre eles; nestes processos as composições isotópicas dos reservatórios tendem a se homogeneizar.

Cada ambiente geológico: crosta superior, crosta inferior, arcos maduros, ilhas oceânicas possuem composições isotópicos particulares que permitem sua diferenciação. Por tanto com as relações das razôes ${ }^{206} \mathrm{~Pb} /{ }^{204} \mathrm{~Pb},{ }^{207} \mathrm{~Pb} /{ }^{204} \mathrm{~Pb}$ e ${ }^{208} \mathrm{~Pb} /{ }^{204} \mathrm{~Pb}$, é possivel conhecer os ambientes geológicos de formação de rochas.

Zartman e Doe (1981) elaboram diagramas ${ }^{208} \mathrm{~Pb} /{ }^{204} \mathrm{~Pb} \times{ }^{206} \mathrm{~Pb} /{ }^{204} \mathrm{~Pb}$ e ${ }^{207} \mathrm{~Pb} /{ }^{204} \mathrm{~Pb} \times{ }^{206} \mathrm{~Pb} /{ }^{204} \mathrm{~Pb}$, onde estão representadas curvas de evolução dos isótopos de $\mathrm{Pb}$ para o manto, crosta superior, crosta inferior e ambiente orogênico; nestas curvas a evolução isotópica do $\mathrm{Pb}$ na terra é simulada com um crescimento de crosta continental em séries de orogenias cada $400 \mathrm{Ma}$. 


\section{GEOLOGIA REGIONAL}

\subsection{CONTEXTO TECTÔNICO}

O território da Colômbia está localizado na intercessão das placas litosféricas da América do Sul, Nazca, Caribe e do Bloco do Panamá. Do ponto de vista tectônico seu território é dividido em duas regiões pelo Sistema de Falhas do Guaicáramo ou de Borde LLanero (SFG): a primeira de natureza cratônica localizada no oriente do Pais (oriente do SFG) na região conhecida como "LLanos Orientales y Amazonía", a qual é caracterizada por apresentar uma morfologia suave e de planícies; a segunda região tectonicamente instável, é constituída pelos Andes Colombianos que apresentam três cadeias montanhosas, a saber: Cordilheiras Ocidental, Central e Oriental que se estendem com direção aproximada norte-sul.

A região cratônica faz parte da borda NW do Cráton Amazônico, e inclui as seguintes unidades: Complexo Migmatítico de Mitú (CMM) com idades Rb-Sr isocrônicas entre 1780 e $1405 \mathrm{Ma}$ (Priem et al., 1982); o Grupo Roraima e a Formação La Pedrera que cobrem o CMM: apresentam idades mínimas K-Ar de 1850 e 1500 (em diques de diabásio que o intrudem) (Keats, 1976); a Formação Piraparana, seqüência vulcanosedimentar com idades K-Ar de 920 e 764 Ma, e Rb-Sr convencional de 1200 $\mathrm{Ma}$ (Priem et al., 1982). Segundo as províncias definidas por Tassinari et al. (1999), essas unidades fariam parte das províncias geocronológicas Ventuari-Tapajós (1,951,80 Ga) e Rio Negro-Juruena (1,8-1,55 Ga).

Os Andes Colombianos são uma colagem de orógenos e terrenos suspeitos originada desde o Neoproterozóico até hoje. Podem-se dividir em dois domínios geológicos principais limitados pelo Sistema de Falhas de Cauca-Romeral (SFCR); o primeiro a leste do SFCR, é de afinidade siálica sendo constituído pela borda oriental da Corditheira Central e a Corditheira Oriental; o segundo a oeste do SFCR, é de afinidade simática sendo representado pela Cordilheira Ocidental.

O domínio de afinidade siálica, apresenta um embasamento metamórfico precambriano e paleozóico; que na Cordilheira Central é intrudido por batólitos de 
idades mesozóicas e cenozóicas e na Cordilheira Oriental é coberto amplamente por seqüências sedimentares paleozóicas, mesozóicas e localmente cenozóicas que foram afetadas por falhamentos do tipo normal no Mesozóico, e no Cenozóico superior por dobramentos e falhamentos de tipo reverso e de empurrão, que causaram o levantamento da Cordilheira Oriental (Cooper et al., 1995; Taboada, 2000); localmente encontram-se rochas vulcânicas do Triásico na parte norte da Cordilheira Central e Cordilheira Oriental, assim como na parte sul da Cordilheira Oriental. Esse domínio foi originado pela acreção sucessiva de terrenos até o Paleozóico inferior (Etayo et al., 1986) ou desde o Paleozóico superior até o Cretáceo superior (Toussaint e Restrepo, 1989); e foi afetado por rifteamento no Permiano ou Triásico (Etayo et al., 1986).

O segundo domínio, de afinidade simática, é constituido por rochas de crosta oceânica, basaltos e sedimentos marinhos, de idade cretácica, afetados por vulcanismo e magmatismo no Cenozóico e cobertos por rochas sedimentares cenozóicas; foi originado pela acreção sucessiva de terrenos alóctones no Mesozóico e Cenozóico (Aspden et al., 1987; Etayo et al., 1986; Restrepo e Touissant, 1988).

No Mioceno médio (12.9-11.8 Ma) o bloco do Choco, de natureza alóctone (arco Panamá-Choco) foi acrecionado, à Cordiheira Ocidental, sendo a zona de sutura representada pela falha de Uramita (Duque-Caro, 1990); a colisão ocasionou o movimento sinistral do Sistema de Falhas de Cauca-Romeral na região norte do Pais (Paris e Romero, 1994; Ego et al., 1995); os movimentos transcorrentes do Sistema de Falhas de Cauca Romeral deram origem a bacias do tipo "pull apart" ocasionando o adelgaçamento do embasamento permitindo desta forma a intrusão dos corpos subvulcânicos da Formação Combia (Ordoñez, 2001). O Pórfiro de Marmato, encaixante da mineralização objeto deste estudo, é um corpo subvulcânico pertencente à Formação Combia, intrudido no Sistema de Falhas de Cauca Romeral no Mioceno tardio (Restrepo et al., 1981); a última movimentação do SFCR, ocorreu há 5,6 Ma $\pm 0,4$ (Vinasco, 2001) (Figura 15). 


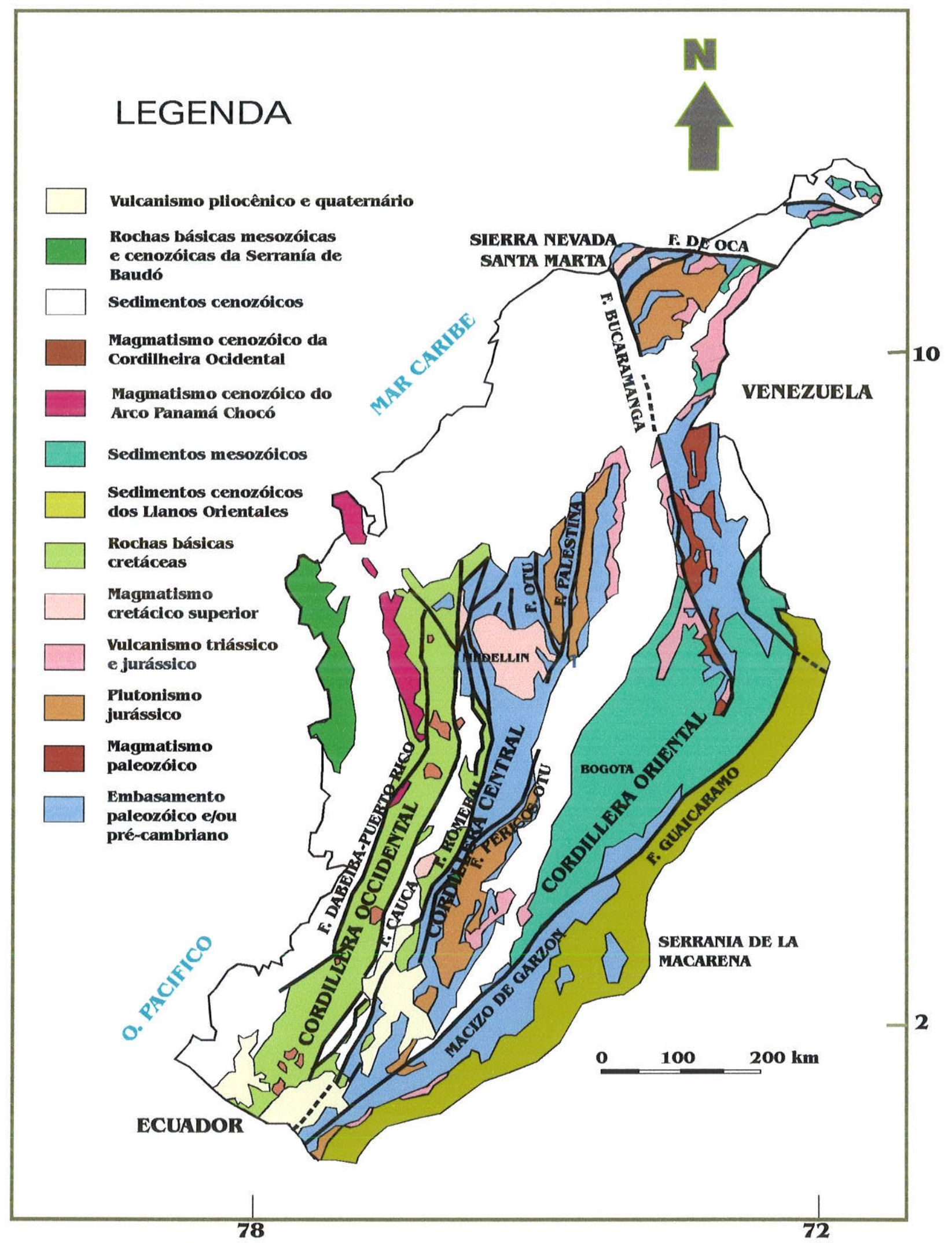

Figura 15. Mapa Geológico da Colômbia. Modificado de Toussaint (1993). 


\subsection{GEOLOGIA DA ÁREA DE MARMATO}

Do ponto de vista regional, as unidades geológicas na região de Marmato alongam-se na direção norte-sul, sendo limitadas por falhamentos importantes pertencentes ao Sistema de Falhas de Cauca Romeral. González et al. (1995) propõe a denominação de Complexos para estas unidades denominando-as de leste para oeste como: Complexo Quebradagrande, limitado a leste pela falha de San Jerónimo e a oeste pela falha de Silvia-Pijao; Complexo Arquía, limitado ao leste pela falha de Silvia Pijao e ao oeste pela falha de Cauca-Almager ou Mistrató; e a Formação Barroso a oeste da falha de Cauca-Almager (Figura, 16). Espalhadas entre os complexos de Arquía e Quebradagrande aparecem corpos de rochas ultramáficas e de grabros como o Stock de Pácora e o Stock de Cambumbia; já a leste do Complexo Arquía, NW do Marmato, aparecem as rochas quartzo-dioriticas do Stock de Támesis. Cobrindo essas unidades ocorrem as Formações Amagá e a parte vulcânica e vulcanosedimentar da Formação Combia.

O Stock de Marmato é um corpo subvulcânico de forma alongada com orientação norte-sul, com aproximadamente $20 \mathrm{Km}$ de comprimento e $5 \mathrm{Km}$ de largura; o qual encontra-se colocado no Sistema de Falhas de Cauca-Romeral, cortando rochas metasedimentares e metavulcânicas do Complexo Arquía, corpos de gabros e rochas ultramáficas, as seqüências sedimentares da Formação Amagá e as rochas vulcânicas e vulcano-sedimentares da Formação Combia.

\subsubsection{ESTRATIGRAFIA}

A descrição geológica das unidades estratigráficas foi baseada nos trabalhos de Calle et al. (1984) e González et al. (1980), que cartografaram as folhas na escala 1: 100.000, 186 Riosucio e 187 Salamina. Para facilidade de descrição, as unidades geológicas aflorantes na região de Marmato, podem ser agrupadas por idades, no Mesozóico e Cenozóico. O Mesozóico incluiu o Complexo Arquía, os corpos de gabros, 


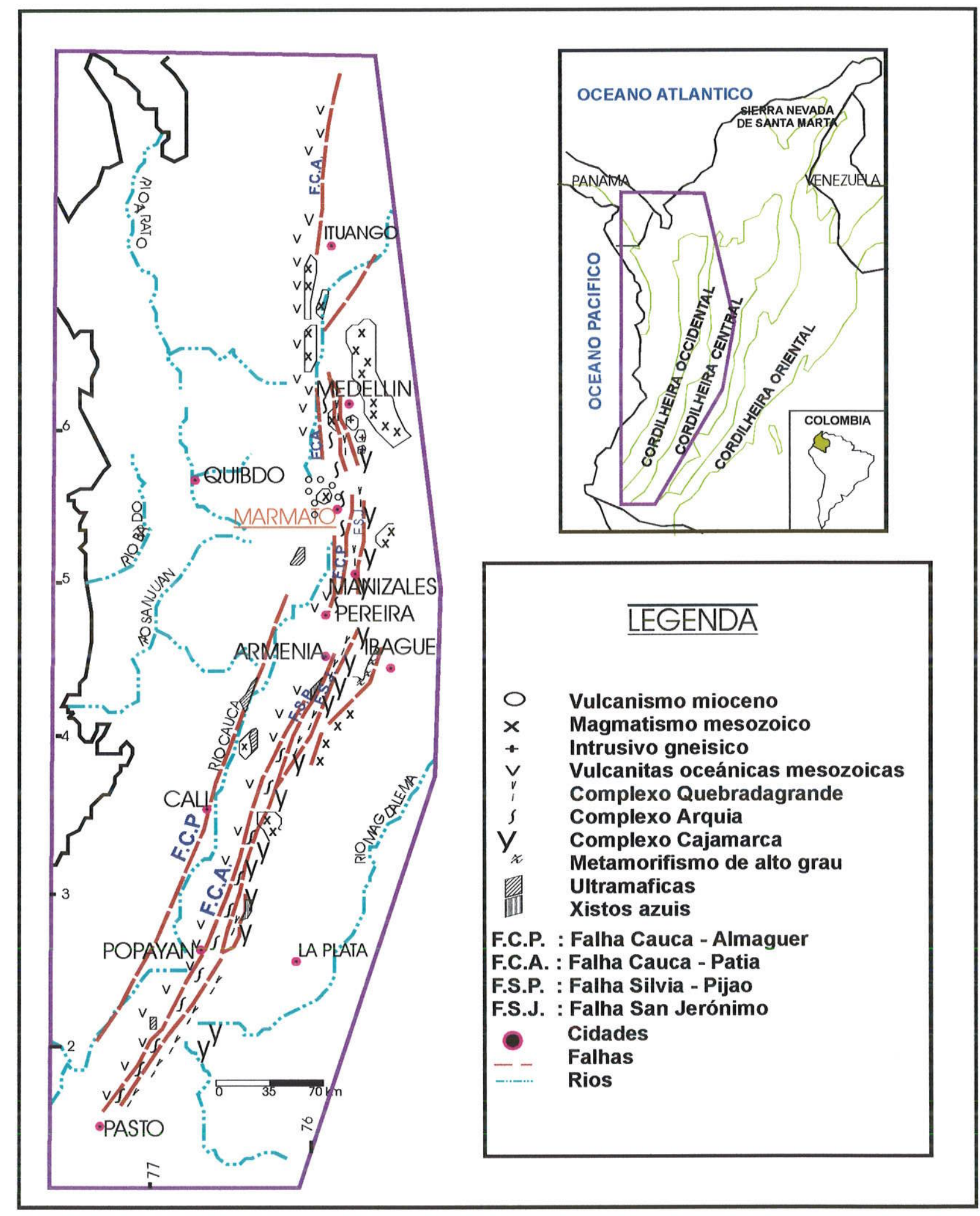

FIGURA 16. Localização geológica do Complexo Arquía na Colômbia. Modificado de González et al. (1995) 
- Stock de Támesis, os Complexos ofiolíticos e rochas ultramáficas. O Cenozóico compreende a Formação Amagá e a Formação Combia (Figura 17).

\subsubsection{Unidades Mesozóicas}

\section{a. Complexo Arquía}

Esta unidade estratigráfica foi denominada como Grupo Arquía por Restrepo e Toussaint (1975); como Xistos do Rio Cauca por González (1976) e Calle et al. (1984); e como Complexo Arquía por González (1995).

Calle et al. (1984) divide esta unidade em: (i) xistos quartzo-sericiticos com laminações finas compostas por quartzo, plagioclásio, muscovita, clorita, biotita, calcita, grafita, ocasionalmente clinozoisita, cloritóide, granada e como acessórios esfeno, zircão e ilmenita. (ii) xistos anfibolíticos, localmente com granada. Os xistos anfibolíticos apresentam variações mineralógicas a xistos cloríticos compostos de plagioclásio, clorita, clinozoisita, e de menor proporção actinolita; e variações a xistos actinoliticos compostos por: plagioclásio, actinolita, e menor proporção de clinozoisita e clorita de origem secundária. (iii) Os anfibolitos são de granulação fina a grossa, apresenta foliação e são bandados. Mineralogicamente, apresentam bandas claras compostas de plagioclásio, epídoto; bandas escuras compostas de hornblenda; localmente apresenta textura porfiroblástica, com grãos de granada, hornblenda e plagioclásio. De acordo com a presença de almandina, o metamorfismo é de pressão media estando no fácies epidoto-anfibolito.

A idade desta unidade é ainda discutível. Segundo Calle et al. (1984) esta unidade é de idade Paleozóica, com metamorfismo Cretácico. Restrepo e Toussaint (1974) admitiram idade Jurássica; Restrepo e Toussaint (1975); com base na idade KAr de $110 \pm 8 \mathrm{Ma}$ obtida em hornblenda de xisto actinolítico e de $110 \pm 5 \mathrm{Ma}$, K-Ar em anfibólio de Anfibolito, colocou este grupo no Cretáceo inferior e Toussaint e Restrepo (1976) consideraram a idade de $108 \mathrm{Ma}$. (K-Ar em xisto actinolítico) como do ultimo evento térmico. 


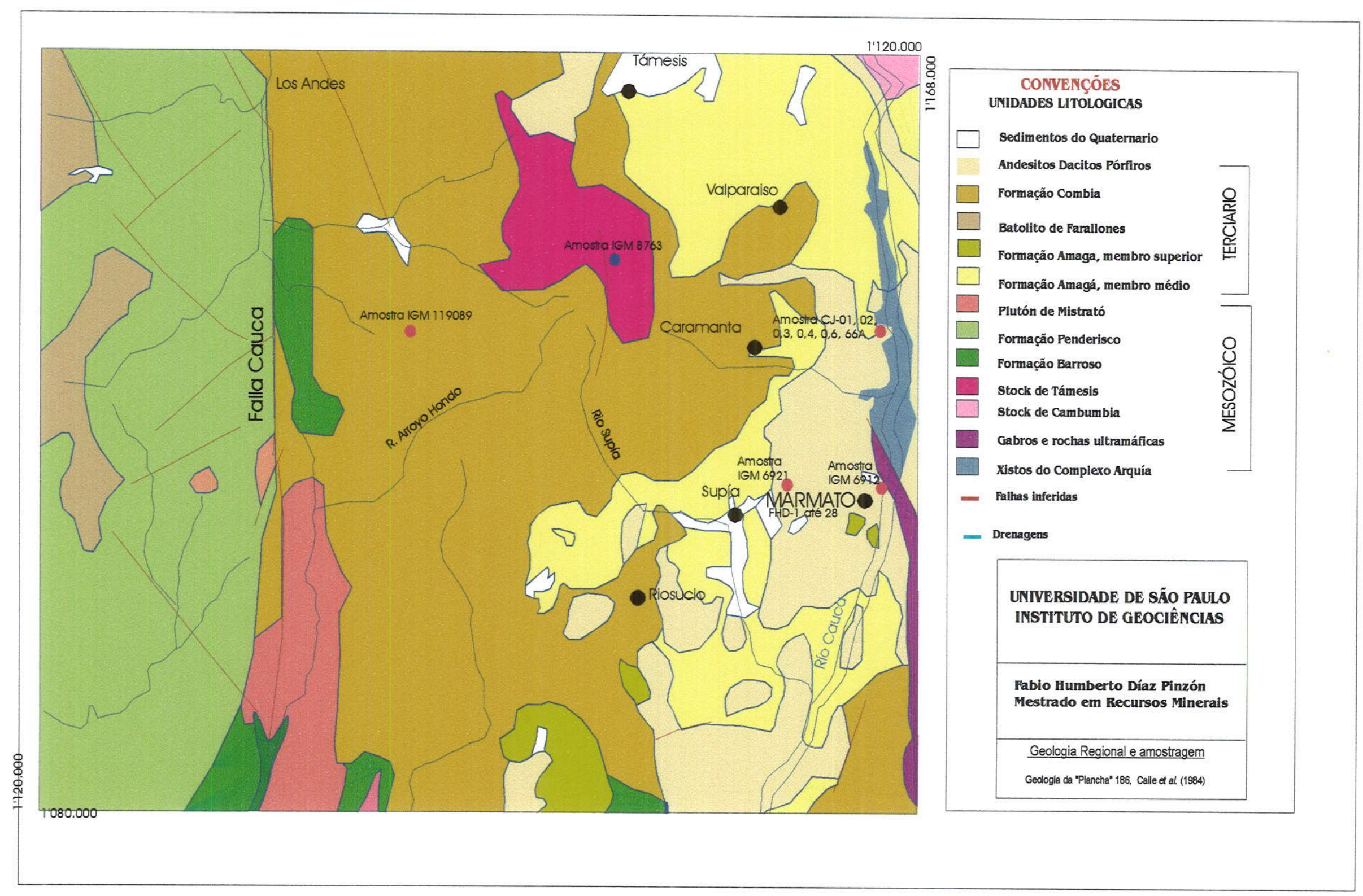

Figura 17. Mapa Geológico Regional da região de Marmato (Calle et al., 1984) 


\section{b. Gabros}

Calle et al. (1984) descreve os gabros como rochas de granulação media, compostos por plagioclásio, hornblenda, sericita, zoisita-clinozoisita, clorita, calcita e epidoto; como minerais acessórios apresentam-se biotita, esfeno e apatita e como opacos, magnetita-ilmenita alterada a esfeno. Estas rochas são consideradas por aqueles autores como pertencentes a Complexos Ofiolíticos quando estão associadas a rochas ultramáficas; mas também como corpos intrusivos que podem ser correlacionáveis com os gabros de Pueblito, que segundo Vinasco (2001) são de idade Triásica.

\section{c. Rochas U/tramáficas}

Conforme Calle et al. (1984) as rochas ultramáficas são serpentinitos, com ocorrência local de peridotitos parcialmente serpentinizados. Estes serpentinitos são maciços, de cor verde, xistosos de granulação fina e contém óxidos de ferro; apresentam ainda textura alotriomórfica e são compostos de antigorita e minerais opacos.

\section{d. Stock de Támesis}

O Stock de Támesis, inicialmente definido por Calle et al. (1984), é composto por rochas equigranulares de granulação média, textura hipidiomórfica, localmente pegmatítica ou Porfírica. Seus componentes são plagioclásio, augita, hornblenda, biotita e localmente ortoclásio. Os minerais acessórios são: clorita, zircão, apatita e ilmenita. Apresenta fácies dioríticas, granodioriticas e gabróides. Sua idade é de $124 \pm 6 \mathrm{Ma}$. conforme uma datação K-Ar em hornblenda (Calle et al., 1980). 


\section{e. Complexo Quebradagrande}

O Complexo Quebradagrande foi definido inicialmente como Formação por Grosse (1926), posteriormente González et al. (1995) o denomina como Complexo. Consiste de dois membros: o primeiro de origem vulcânico constituido principalmente por diabasas, o segundo membro é constituido por rochas sedimentares, argilitos, siltitos, grawackas de granulação fina, localmente alternam rochas vulcânicas. Segundo González et al. (1995) sua idade é cretáceo inferior a médio.

\subsubsection{Unidades Cenozóicas}

\section{a. Formação Amagá}

A Formação Amagá foi definida por Grosse (1926), a divide-se em três membros: superior, médio e inferior.

Calle et al. (1984) descreve o membro inferior como composto por estratos de conglomerados, camadas de até $0.7 \mathrm{~m}$ de carvão, arenitos conglomeráticos e argilitos. O membro médio é constituído por argilitos de cor cinza, arenitos de cor clara e cinza, isoladamente conglomeráticos e capas de carvão até de 3 metros. O membro superior é constituído por arenitos bem cimentados de cor creme, argilas de cor ocre, isoladamente bandas de rochas conglomeráticas e carvão. Sua idade é Oligoceno Superior-Mioceno Inferior (Van Der Hammen, 1960, 1957).

\section{b. Formação Combia}

A Formação Combia foi descrita inicialmente por Grosse (1926). Calle et al. (1984) a descreve como uma unidade vulcano-sedimentar, constituída por uma mistura de rochas piroclásticas, lavas, e rochas vulcanoclásticas. As rochas piroclásticas consistem em aglomerados e brechas com bombas e blocos de basaltos e andesito; e tufos de composição intermedia. As lavas são de composição básica, textura afanítica a 
Porfiritica; com fenocristais de augita, feldspato ou hiperstênio. Apresenta intercalações de tufos, lavas e aglomerados.

Restrepo et al. (1981) denomina aos corpos subvulcânicos de composição andesítico-dacítico (assim como as rochas piroclásticas e lavas intercaladas com rochas sedimentares), como pertencentes ao magmatismo associado à Formação Combia. Essas rochas apresentam idades tanto das lavas como dos corpos subvulcânicos de 9,1 $\pm 1 \mathrm{Ma}$ (K-Ar em rocha total do basalto do Cangrejo); $8 \pm 4 \mathrm{Ma}$ (KAr em hornblenda do Dacito-Pórfiro dos Farallones de La Pintada) e de 6,3 $\pm 0,7$ ( $\mathrm{K}-\mathrm{Ar}$ em hornblenda do Stock de Marmato).

\section{Andesito-Dacito Pórfiros}

Restrepo et al. (1981) menciona entre outros corpos subvulcânicos associados à Formação Combia, o Stock de Marmato, o de Los Farallones de la Pintada, o de "Cerro Tusa" e o de Corcovado. Segundo Alvarez (1983), Marriner e Millwar (1984), Ordoñez (2001) estas rochas intrusivas andesíticas e dacíticas fazem parte de uma serie cálcialcalina a toleitica.

Segundo Calle et al. (1984) os andesito-pórfiros apresentam textura Porfirítica, com fenocristais de plagioclásio e hornblenda, dentro de uma matriz afanítica de cor cinza clara; caracterizam-se, ainda, por apresentar cloritização dos minerais ferromagnesianos e sericitização dos feldspatos. Os dacito pórfiros são rochas de cor cinza clara, por vezes amarelada por alteração supergênica de sulfetos. Os fenocristais são de plagioclásio, quartzo bipiramidal e hornblenda.

\section{Stock de Marmato}

González (1980) descreve este Stock, encaixante dos veios mineralizados, como rochas de cor cinza clara e verde escura com textura afano-porfiritica. A rocha predominante é um andesito pórfiro, com gradaçōes a dacito pórfiro e microdiorito porfirítico. O plagioclásio presente é andesina, ocasionalmente com inclusões de epidoto e quartzo; o quartzo ocorre subordinadamente. A hornblenda é o 
ferromagnesiano mais abundante e como minerais acessórios ocorrem magnetita e pirita disseminada.

As idades reportadas para as rochas sub-vulcânicas, geneticamente relacionadas com o Pórfiro dacítico-andesítico de Marmato, tem sido obtidas pelas sistemáticas Ar-Ar e K-Ar: Vinasco (2001) obteve uma idade Ar-Ar em biotita de 6,75 \pm $0.06 \mathrm{Ma}$; González (1976) no Pórfiro andesítico da Felisa obteve idades K-Ar de 7,1 \pm $0,1 \mathrm{Ma}$ em horblenda e 6,8 $\pm 0,3 \mathrm{Ma}$ em biotita. No pórfiro dacítico-andesítico de Marmato, Restrepo et al. (1981) obtiveram uma idade K-Ar de $6.3 \pm 0.7 \mathrm{Ma}$ em hornblenda.

\subsubsection{ESTRUTURAS}

O Distrito Mineiro de ouro de Marmato encontra-se na parte ocidental do sistema de falhas Cauca-Romeral-Patia, que possivelmente serviram de canal para os corpos subvulcânicos porfiríticos de idade Mioceno superior.

O Sistema de Falhas de Romeral é constituído por uma serie de falhas subparalelas, com direção norte-sul, que se estendem desde o Equador até o norte da Colômbia. Regionalmente este Sistema de Falhas marca o limite entre rochas de afinidade oceânica a oeste e rochas de afinidade continental a leste. Segundo Paris et al. (1994) e Ego et al. (1995), este sistema possivelmente teve um movimento destral no Cretácico, desenvolvendo um movimento lateral esquerdo durante o MiocenoPlioceno no noroeste do país. Ao sul, os movimentos da falha são de tendência inversa com componente lateral direito.

Segundo Calle et al. (1984), na região de Marmato, a zona de cisalhamento de Romeral, tem direção N-NW e apresenta deslocamentos verticais que colocam em contato rochas metamórficas com rochas ultramáficas. 


\section{GEOLOGIA DE MARMATO E MINERALIZAÇÕES AURÍFERAS}

As mineralizações de Marmato consistem de veios distencionais subverticais, com orientação NW, e espessura de até $2 \mathrm{~m}$; preenchidos de pirita, esfalerita, galena, arsenopirita, pirrotita, calcopirita; mais raramente prata, argentita, "polybasite", ouro electrum (Aum $\mathrm{Ag}$ ), teluretos, sulfossais de $\mathrm{Bi}$; como ganga carbonatos e quartzo subordinado. Os veios estão encaixados no Andesito-Dacito Pórfiro do Stock de Marmato, o qual intrude os xistos do Complexo Arquía e as rochas sedimentares da Formação Amagá. Considera-se que os Andesito-Dacito Pórfiros que afloram nas cercanias de Marmato, Riosucio e Supía pertençam ao mesmo sistema intrusivo, podendo estar conectados em profundidade.

A atividade minera no município de Marmato concentramse em quatro setores a saber: Marmato, Echandía, Cien Pesos e Marmato Bajo. Já de forma regional as mineralizações do Marmato fazem parte do denominado Distrito Marmato-SupíaRiosucio, que compreende os municípios dos mesmos nomes, o qual é caracterizado pela presença de várias minas de ouro epitermal encaixadas nesses corpos intrusivos subvulcânicos Porfiriticos.

\subsection{GEOLOGIA LOCAL DE MARMATO}

A descrição da geologia local baseou-se no mapeamento geológico na escala 1:5.000 realizado por Cuellar et al. (1982); nos trabalhos geológicos realizados por González (1980), Buenaventura (1997), Bedoya (1998) e Rossetti et al. (1999); além das observações feitas pelo próprio autor.

Na área do Distrito Mineiro de Marmato, as rochas mais antigas, que constituem o embasamento, pertencem ao Complexo Arquía. Na região afloram de forma isolada no setor de Echandía, sendo representadas por xistos grafitosos compostos por biotitagrafita-quartzo, de fácies anfibolito baixa; e por xistos compostos por cloritaplagioclásio-quartzo, de fácies xistos verdes (Rossetti et al., 1999). 
Observam-se, em pouca extensão, no denominado Alto do Burro e ao NW de Echandía, rochas sedimentares do Mioceno, pertencentes à Formação Amagá, particularmente do seu membro superior. Esta Formação está representada, nesse setor, por folhelhos da cor verde que apresentam laminação pobre; e conglomerados compostos de seixos arredondados de quartzo e fragmentos de rocha (Buenaventura, 1997).

A rocha mais recente da região é o Andesito-Dacito Pórfiro de idade Mioceno superior, que aflora amplamente no município de Marmato e constitui a rocha hospedeira das mineralizações.

Os principais traços estruturais da área de Marmato são alguns falhamentos subverticais com direção NE, como a falha o Obispo; assim como pequenas falhas com pouco deslocamento; veios e diaclases distencionais com orientação principal NW e secundaria NE (Figura 18).

\subsubsection{ANDESITO-DACITO PÓRFIRO DE MARMATO}

Os corpos subvulcânicos Porfiriticos, são de composição dacítica no centro e andesítica nas bordas, segundo Rossetti et al. (1999) apresenta mudanças texturais de forma gradual, mas sendo formado primeiro o andesito pórfiro e depois o dacito pórfiro. $\mathrm{Na}$ área de Marmato os andesito-dacito pórfiros estão afetados por ampla propilitização, e localmente na zona dos veios mineralizados por forte alteração fílica.

\subsubsection{Andesito Pórfiro}

$O$ andesito pórfiro aflora ao oeste do município de Marmato e também ao oeste da rodovia Medellin-Manizales, na parte inferior da vila El LLano (Figura 18). No setor de Echandía na mina Plata Fría, são as encaixantes dos veios mineralizados e estão afetadas por alteração propilitica (amostras FHD-4 e FHD-6); estas rochas são andesitos com textura porfírica composta por fenocristais de plagioclásio (alterados a 


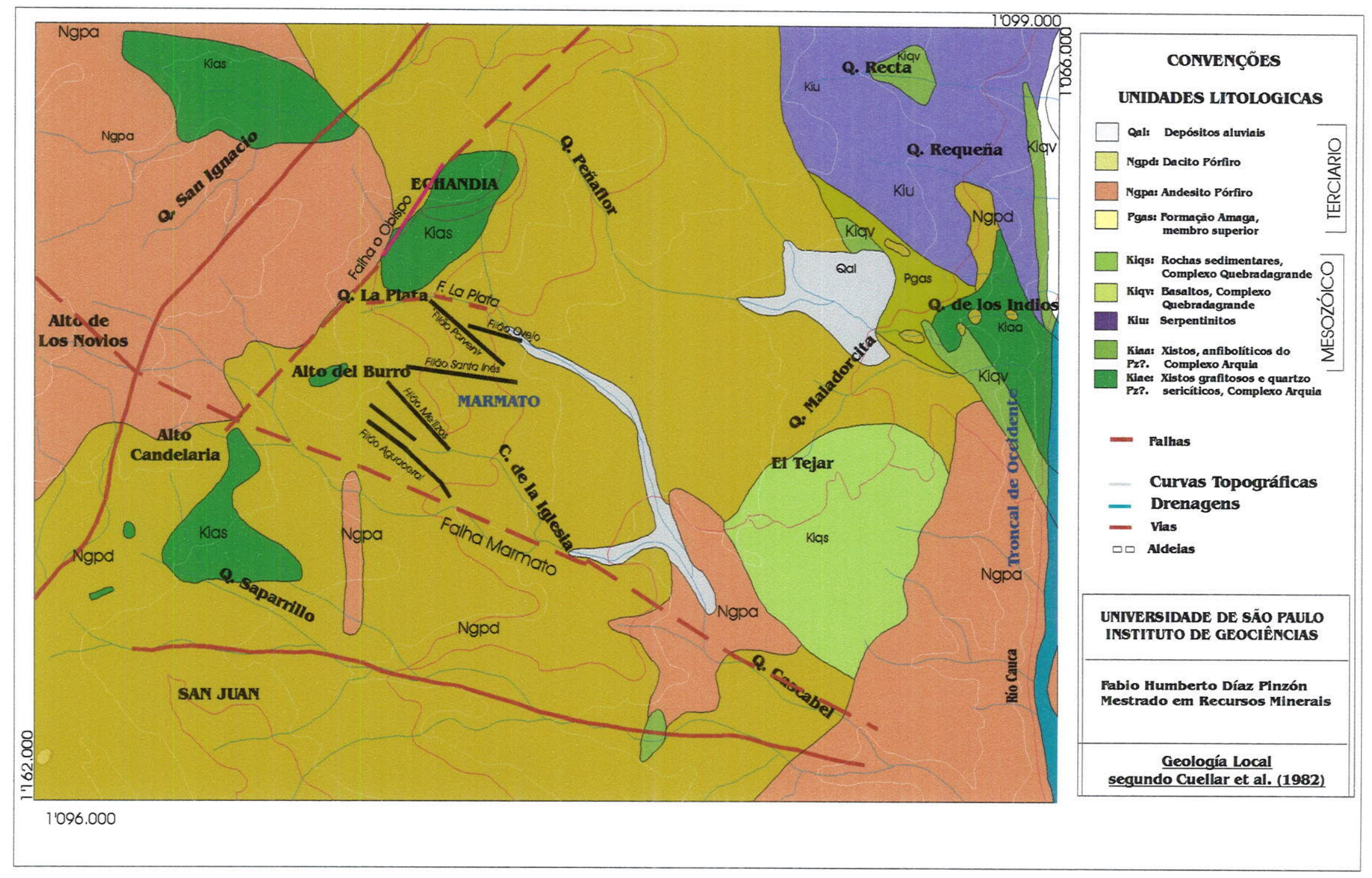

Figura 18. Mapa de Geologia local (Cuellar et al., 1982) 
sericita e carbonato), minerais máficos (alterados a clorita, carbonatos, óxidos e esfeno segundo Rossetti et al. (1999)) e mais raramente pequenos cristais de quartzo corroídos; todo dentro de uma matriz microcristalina inequigranular muito fina composta por plagioclásio e clorita (subordinadamente por sericita e calcita); também contem magnetita mais raramente apatita, epidoto e zircão. Os fenocristais de plagioclásio (andesina) são de granulação grossa (2 a $4 \mathrm{~mm}$ ), estão zonados e maclados; os minerais máficos são constituidos por hornblenda e biotita geralmente cloritizados.

\subsubsection{Dacito Pórfiro}

O Dacito Pórfiro aflora no setor de Echandía (minas: La Palma, La Negra, La Maria, Aguaceral), no setor de Cien Pesos e no setor de Marmato Bajo; é a encaixante dos veios, onde pode estar propilitizado (amostras FHD-20 e FHD-28). A rocha é um dacito com textura porfirítica constituído por fenocristais de plagioclásio (alterado a sericita, calcita, epidoto), quartzo e minerais máficos (alterados a clorita, calcita e óxidos); todos dentro de uma matriz equigranular muito fina composta de plagioclásio, quartzo, sericita e carbonatos; também contem abundante magnetita e subordinadamente apatita. Os fenocristais de plagioclásio (andesina) estão maclados e zonados (Figura 19), segundo Rossetti et al. (1999) quando frescos apresentam uma zonação inversa (albita 86, anortita 14 no núcleo; e albita 83 , anortita 17 nas bordas); o quartzo é de granulação grossa, apresenta bordas corroídas e formas de golfos; os máficos, hornblénda e biotita, geralmente estão cloritizados.

\subsubsection{Outras rochas associadas ao Andesito-Dacito Pórfiro}

Rossetti et al. (1999) a partir de amostras de testemunhos de sondagem, sugere a presença de diques de até 10 metros de espessura de andesito megaporfirítico cortando o Andesito-Dacito Pórfiro. Estas rochas seriam formadas por fenocristais de plagioclásio e anfibólio de granulação grossa até $2.5 \mathrm{~cm}$, raramente quartzo corroído; a matriz é fina composta por agregados de clorita e calcita; localmente aparecem restritos opacos e apatita. O plagioclásio apresenta zonação oscilatória (albita 59, 


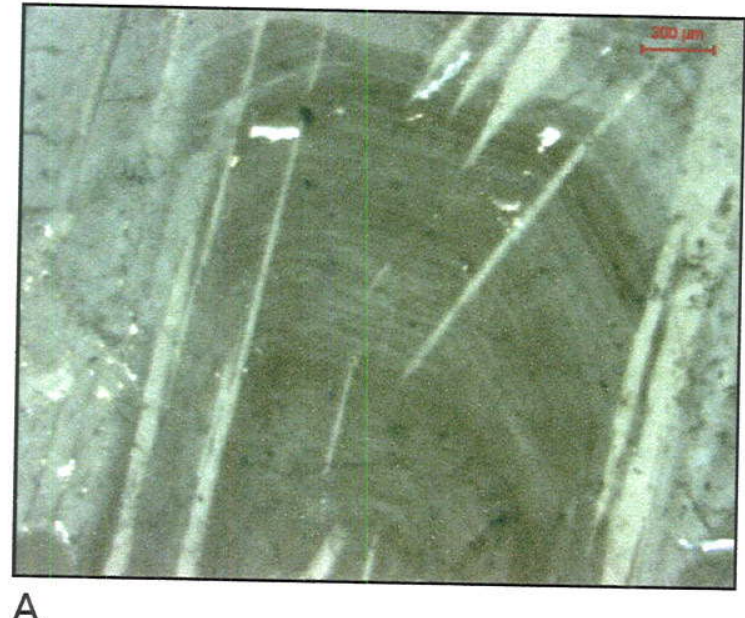

A

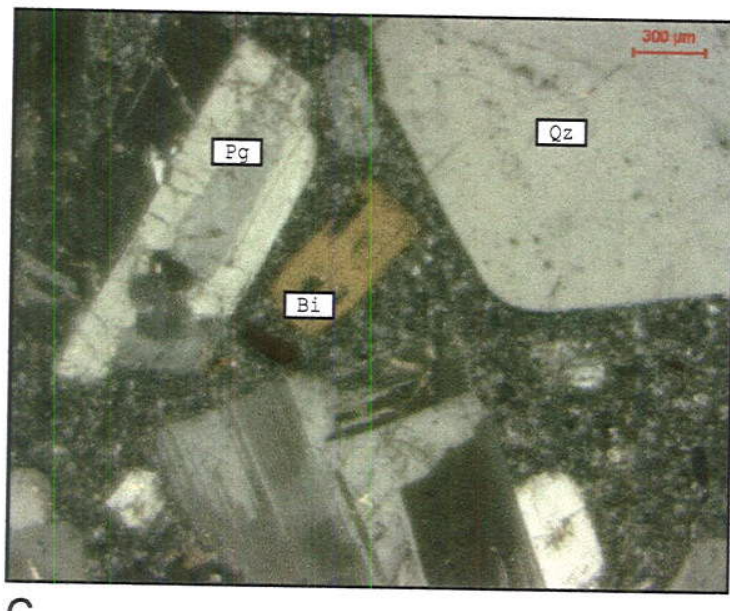

C

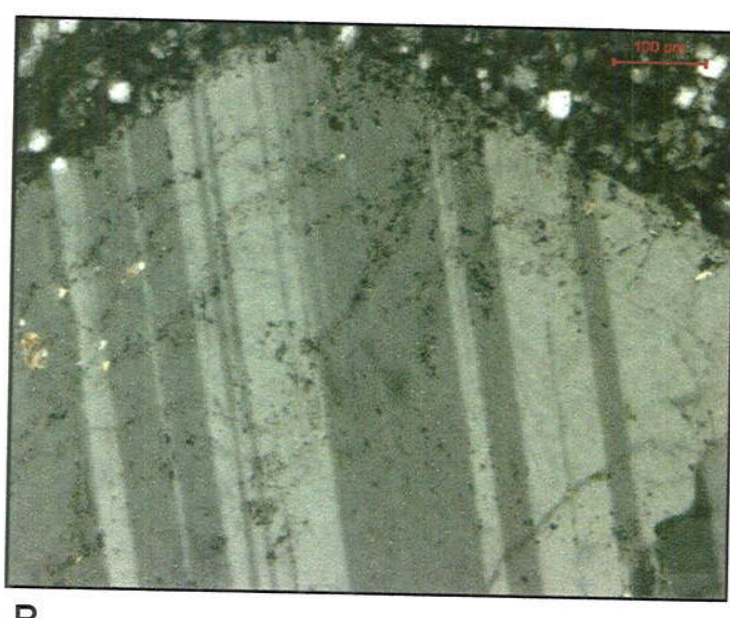

B

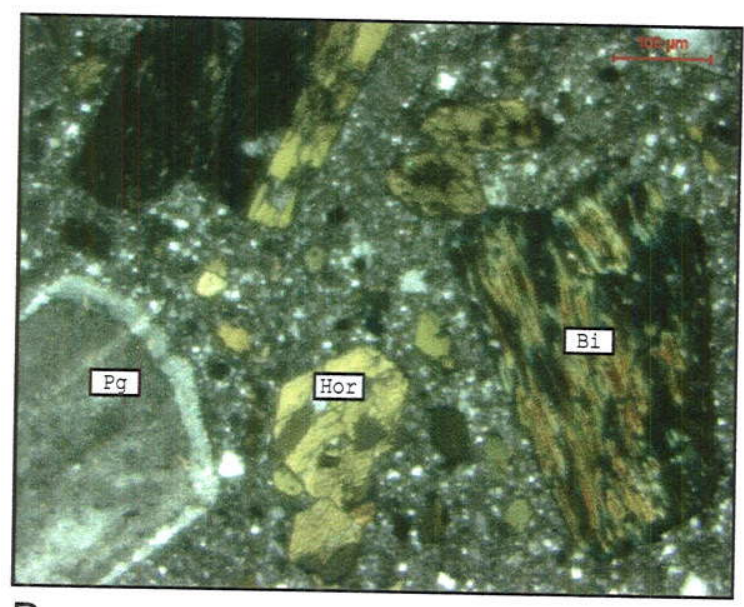

D

Figura 19. Andesito-Dacito Pórfiro, imagem no microscópio de luz transmitida, com nicois cruzados. A) Plagioclásio zonado, amostra FHD-20. B) Plagioclásio maclado, amostra IGM 6921. C) Fenocristais de plagioclásio $(\mathrm{Pg})$, quartzo $(\mathrm{Qz})$ e biotita $(\mathrm{Bi})$ em matriz dacítica, amostra CJ01. D) Fenocristais de máficos (biotita e hornblenda (Hor)) e plagioclásio em matriz dacítica, amostra
CJ-66A. 
Anortita 41 no núcleo e nas bordas albita 92, anortita 8), geralmente está altera do a calcita e sericita. A hornblenda altera a um inter-crescimento de clorita, carbonatos, sericita e óxidos de titânio e esfeno. Para Rossetti et al. (1999) o andesito megaporfiritico é posterior à formação do Andesito-Dacito Pórfiro.

\subsubsection{ASPECTOS ESTRUTURAIS}

Os principais traços estruturais da área de Marmato são alguns falhamentos do tipo subvertical, falhamentos de pouco deslocamento, veios distencionais e diaclases dilatacionais. Os falhamentos principais apresentam orientação N, NE e NW; na zona das mineralizações o acidente mais importante é a falha o Obispo, a qual apresenta orientação N25E e coloca em contato rochas do Complexo Arquía com o Dacito Pórfiro de Marmato; também a Falha da Quebrada La Plata, a qual apresenta orientação N70W e segundo Buenaventura (1997) está relacionada com os veios mineralizados da zona. As diaclases dilatacionais apresentam uma extensão de poucos metros e não tem preenchimento; já nos veios distencionais que foram os canais dos fluidos mineralizantes, encontram-se minerais idiomórficos de origem hidrotermal e texturas de "pente", indicando um crescimento em espaço aberto.

Segundo Rossetti et al. (1999) na parte central do município de Marmato existiram três eventos de deformação: dúctil, dúctil-frágil e rúptil; B1, B2, B3, respectivamente.

- O evento B1 afeta os xistos do Complexo Arquía e foi anterior aos corpos subvulcânico Porfiríticos.

- O evento B2 afeta a Formação Amagá e os corpos subvulcânicos. Originou cataclasitos nas bordas dos corpos intrusivos; e pode estar relacionado com a colocação dos corpos magmáticos nas rochas sedimentares encaixantes.

- O evento B3, foi posterior à intrusão dos corpos subvulcânicos, afetou as rochas da Formação Amagá e os Andesito-Dacito Pórfiros. É representado por diaclases dilatacionais dispersas e veios distencionais que hospedam a mineralização. 
Apresentam-se duas orientações principais, A e B. O sistema A foi o principal canal dos fluidos hidrotermais durante o evento mineralizante de ouro, tem uma orientação dominante N7OW e é constituído por diaclases, veios distencionais e isoladamente, por pequenos falhamentos. O sistema $B$, com orientação principal $N 50$ E, é composto por diaclases e isoladamente por falhas pequenas.

No setor de Echandía, nos níveis La Maria e Aguaceral as estruturas que controlam a mineralização têm orientação N40-60W (López-Rendón, 1991); nos níveis de La Palma e La Negra, a orientação das estruturas é N60-80W (López-Rendón e Bedoya, 1991). No setor de Cien Pesos, na mina La Mona, a orientação é E-W (Restrepo, 1989); na mina Villonza, N55-71W (Medina, 1989). No setor de Marmato Bajo os filões têm as seguintes orientações: N30-40W, N40-55W, N55-75W, N60W (Bedoya, 1998).

\subsection{DESCRIÇÃO DAS MINERALIZAÇÕES}

No Distrito Mineiro de Marmato encontram-se varias minas que extraem e beneficiam ouro; podem-se distinguir quatro setores principais onde concentra-se a atividade minera: Echandia, Cien Pesos, Marmato e Marmato Bajo (Figura 5).

- No setor de Echandía as principais minas são: Plata Fría, La Maria, Aguaceral, La Negra, La Felicia e La Palma; com cotas entre 1600 e 1450 metros.

- No setor de Cien Pesos encontram-se as minas: La Ratonera, Torno II, La Wakonda, La Mona, Villonza e la Dorotea; com cotas entre 1430 até 1300 metros.

- No município de Marmato encontrasse a mina El Doscientos, com cota de 1300 metros

- No setor de Marmato Bajo, encontra-se a mina La Maruja com cotas entre 1260 até 160 metros. 
Visando obter maior clareza nas descrições e interpretações, as mineralizações do Distrito de Marmato foram divididas informalmente em três níveis do sistema hidrotermal: parte superficial, referente ao setor de Echandía; parte intermediaria, referente ao setor de Cien Pesos; e parte profunda, referente ao setor de Marmato Bajo.

\subsubsection{MINÉRIO E PARAGÊNESE MINERAL}

No Distrito Mineiro de ouro de Marmato, as mineralizações encontram-se em veios distencionais com espessuras de até de $2 \mathrm{~m}$, continuidade horizontal de até $250 \mathrm{~m}$, e de $50 \mathrm{~m}$ na vertical; a mineralização também se apresenta como brechas mineralizadas e como stockwork.

Os veios apresentam zonação lateral, nas paredes formam-se bandas de abundante pirita, a qual também invade às encaixantes como microveios; na parte central dos veios, podem ser encontradas bandas de esfalerita; entre os espaços libres do veio, foram depositados os restantes sulfetos e os minerais de ganga. As brechas estão preenchidas de carbonato e poderiam ter invadido os veios previamente fraturados (López-Rendón e Bedoya, 1989; López-Rendón, 1991).

No setor de Echandía os minerais mais abundantes são: pirita, esfalerita, galena; menos abundante calcopirita, arsenopirta, pirrotita; mais raramente argentita, ouro, electrum (Au-Ag) (López-Rendón e Bedoya, 1989; López-Rendón, 1991). No setor de Marmato Bajo os minerais mais abundantes são: pirita, pirrotita, esfalerita, arsenopirita, calcopirita, ouro, galena, marcasita, "polybasite” (Bedoya, 1998).

\subsubsection{Relações mineralógicas}

As relações mineralógicas dos minerais de minério foram realizadas a partir do levantamento bibliográfico e das descrições das seções polidas (feitas no microscópio de luz refletida e no MEV para a seleção e interpretação das análises isotópicas). 


\section{a. Ouro-Prata}

Foi encontrado ouro electrum (Au-Ag), como mineral acessório, em todos os setores do Distrito Mineiro de Marmato. Apresenta-se como microgrãos e preenchendo microfraturas nas piritas (amostras FHD-7, FHD-14, FHD-21) e como microglóbulos dentro de galena (FHD-7, associado a prata e teluretos); a relação Au:Ag, varia nas piritas de 1:1 até 4:1, e nas galenas é de 1:1 (Figura 20,21).

No setor de Echandía, segundo López-Rendón (1991) o ouro está dentro de pirita, intercrescido com pirrotita, dentro de esfalerita associado a quartzo e dentro de prata. No setor de Cien Pesos o ouro está associado a pirita e esfalerita (Medina, 1989; Restrepo, 1989). No setor de Marmato Bajo, segundo Bedoya (1998) está presente em todos os minerais, entre outros: associado a polybasite em planos de clivagem de pirita, dentro de pirita, associado a carbonato substituindo pirita, associado a calcopirita, dentro de esfalerita, associado a minerais de ganga, dentro de arsenopirita, associado a pirrotita, associado a galena.

\section{b. Prata}

A prata foi encontrada como mineral acessório em todos os setores. Apresentase intercrescida com galena (amostra FHD-2), dentro de esfalerita (amostra FHD-19), em galenas argentíferas (amostra FHD-2, FHD-7, FHD-21 e FHD-23). Observou-se prata associada a teluretos e sulfossais de $\mathrm{Bi}$, substituindo a galena nas bordas, preenchendo microfraturas associada a sulfossais de Bi (amostra FHD-7 e FHD-23). (Figura 22, 23).

No setor de Echandía, segundo López-Rendón (1991) encontra-se argentita dentro de esfalerita e dentro de pirita tardia (Py2). No setor de Marmato Bajo, Bedoya (1998) descreve Polybasite que substitui Pirita (Py1), pirrotita, arsenopirita e esfalerita; está associada com: galena, calcopirita, quartzo e ouro. 

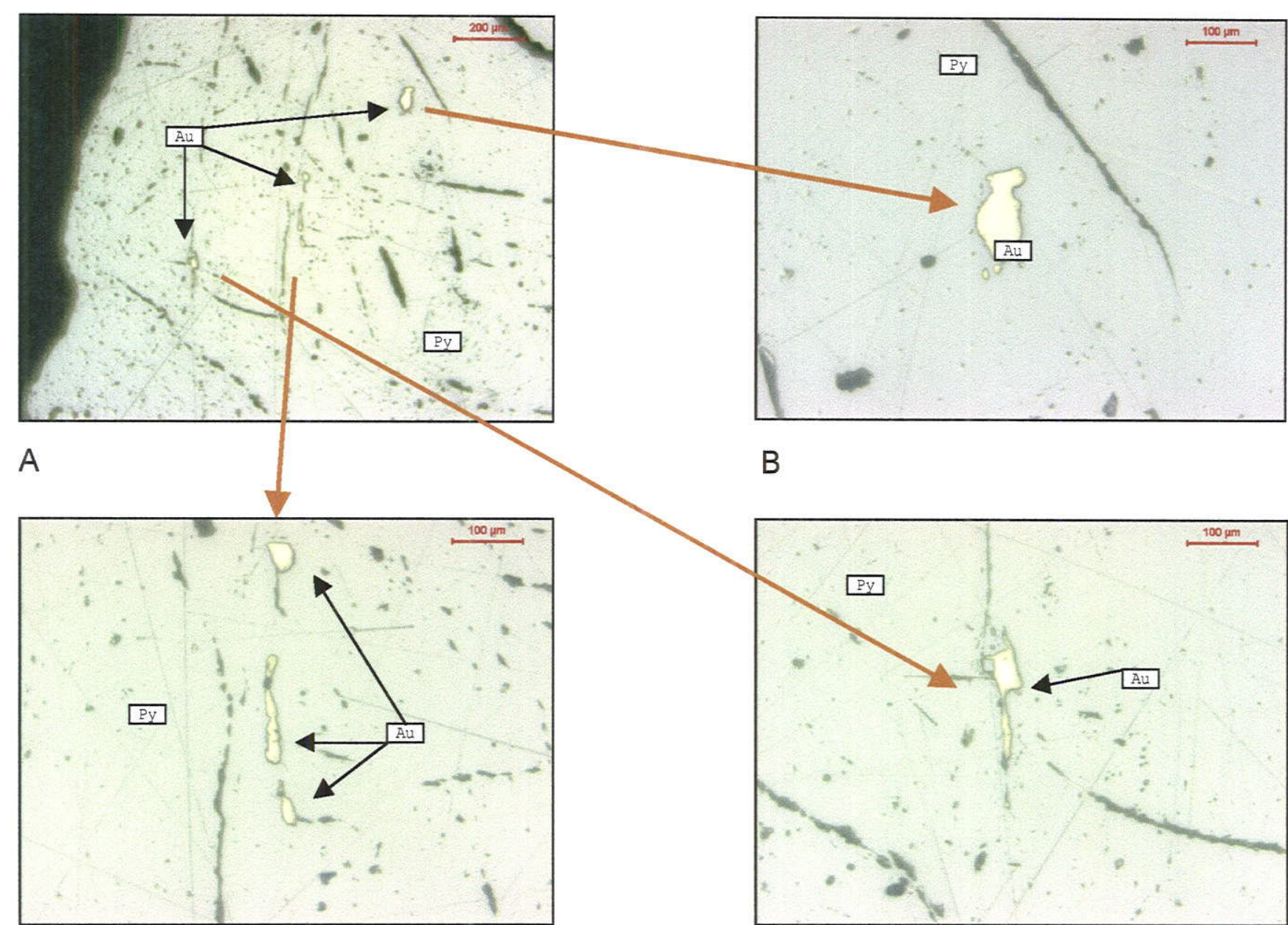

B

C

Figura 20. Amostra FHD14, imagem no microscópio de luz refletida. A, B, C, D) Ouro (Au) em pirita $(\mathrm{Py})$, preenchendo microfraturas e em microgrãos. 

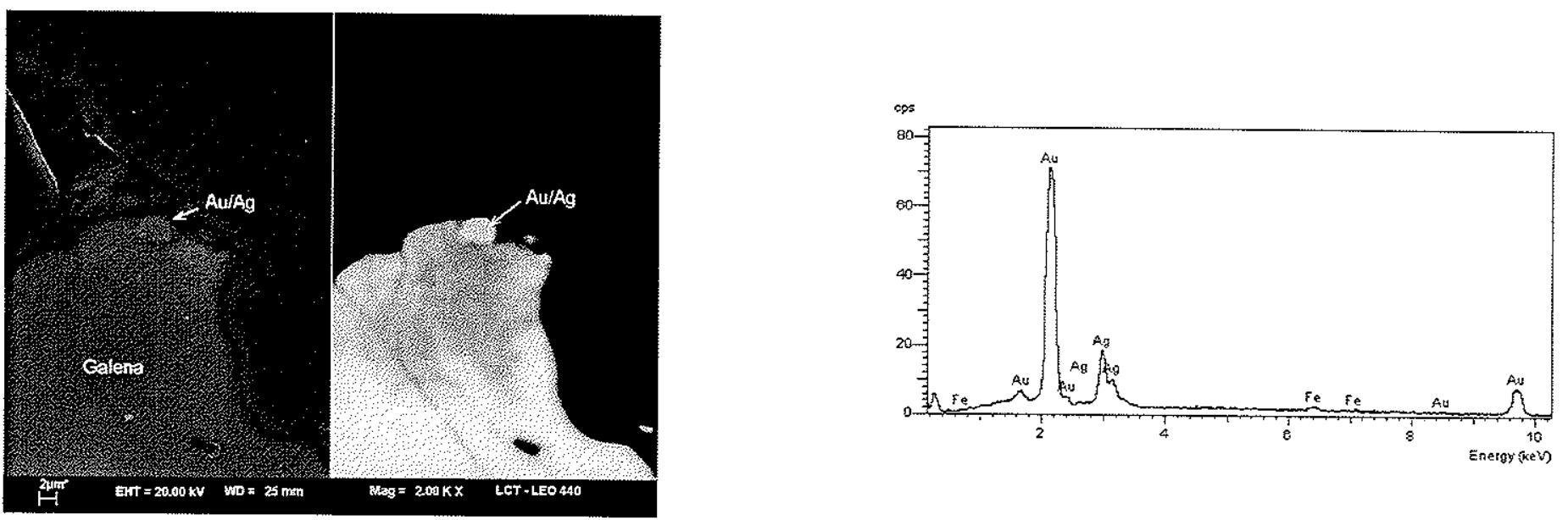

A
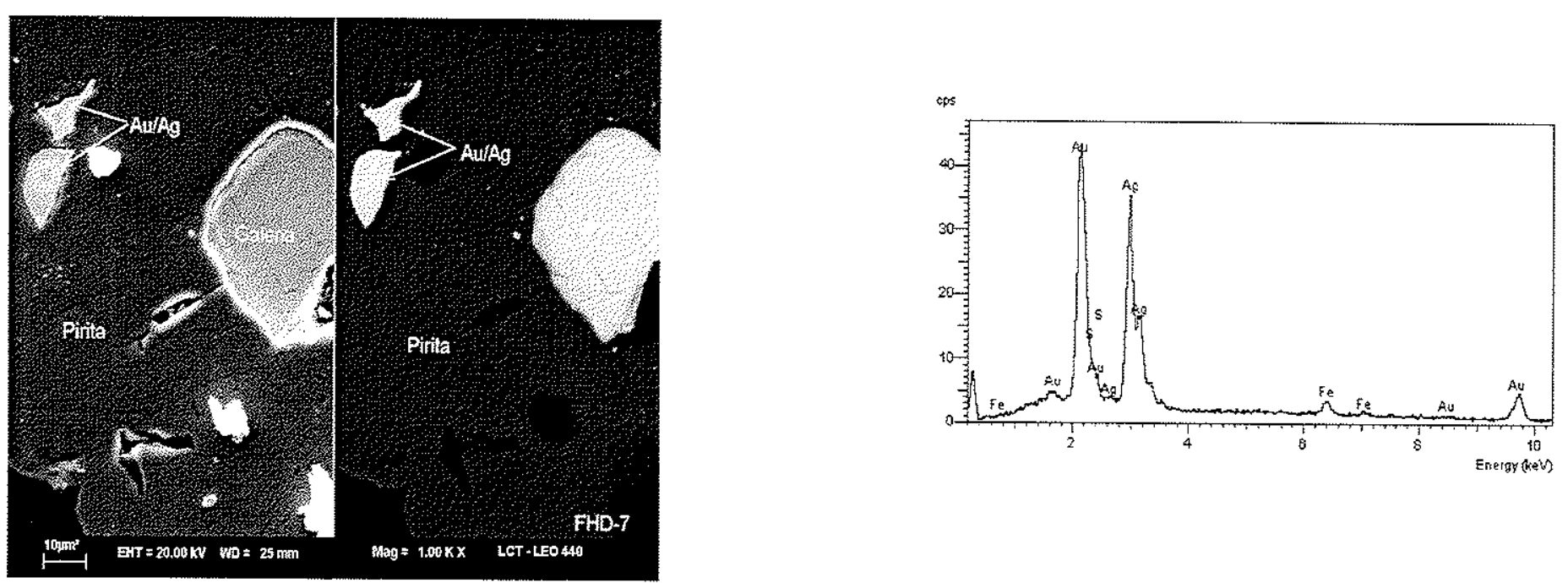

B

Figura 21. Amostra FHD-7. A) Microglóbulo de ouro em galena (Imagens ES e EDS) e espectro. B) Ouro electrum (Au-Ag) em pirita (Imagens ES e EDS) e espectro. 


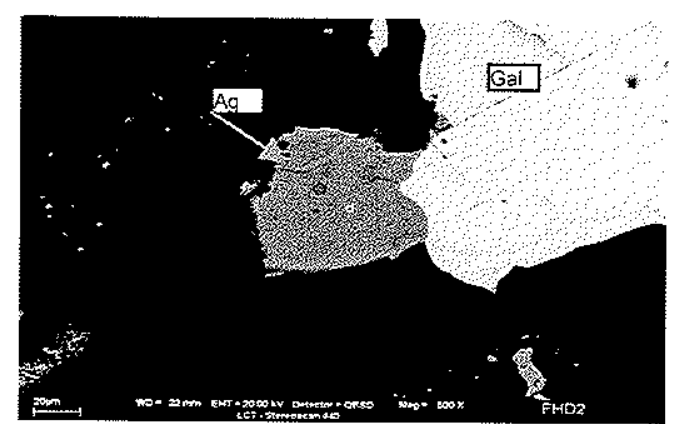

A

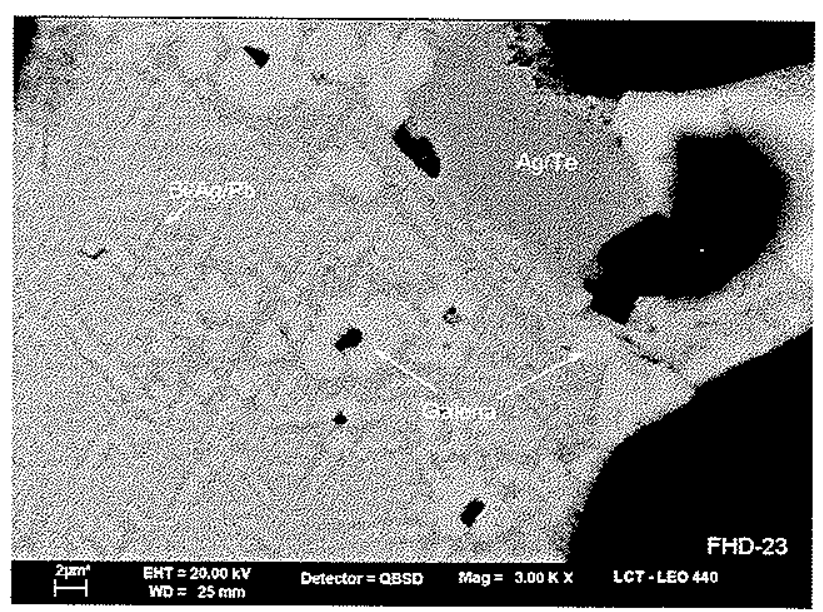

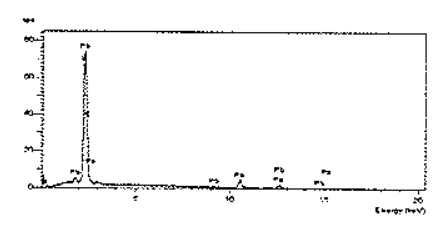

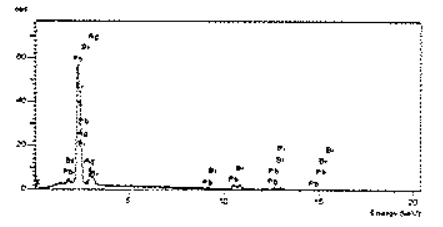

B

Figura 22. Relação Prata-Galena. A) Amostra FHD-2, intercrescimento de galena e argentita (imagem EDS) e espectro. B) Amostra FHD-23, Prata associada a Teluretos; substituição aparente de galena argentífera por sulfossais de Bi-Ag (imagem EDS) e espectro. 


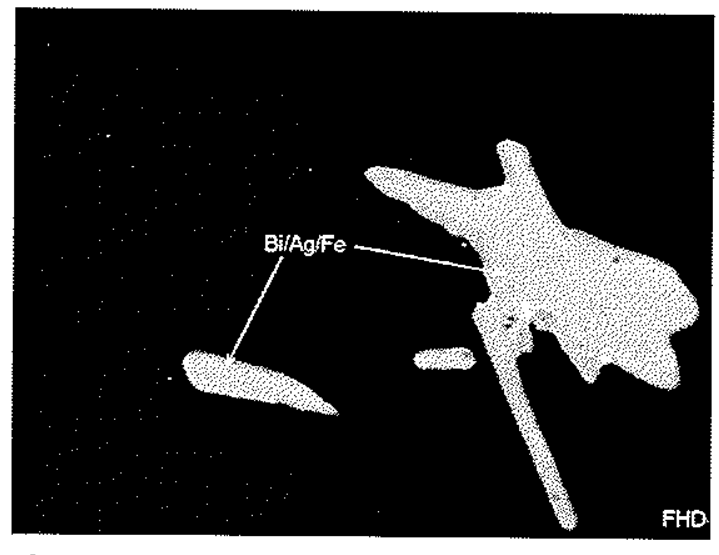

A

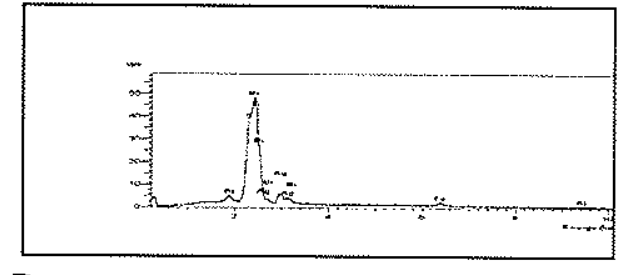

B

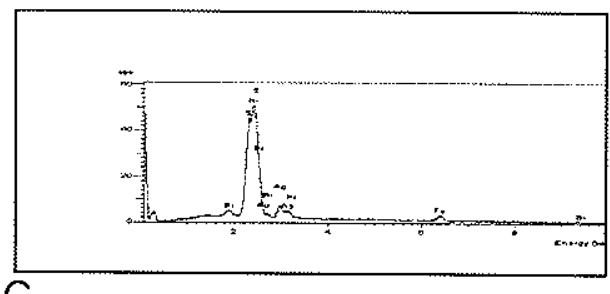

Figura 23. Sulfossal de Bi-Ag preenchendo fraturas. A) Imagem EDS. B e C) Espectro do mineral. D) Análise semiquantitativa.

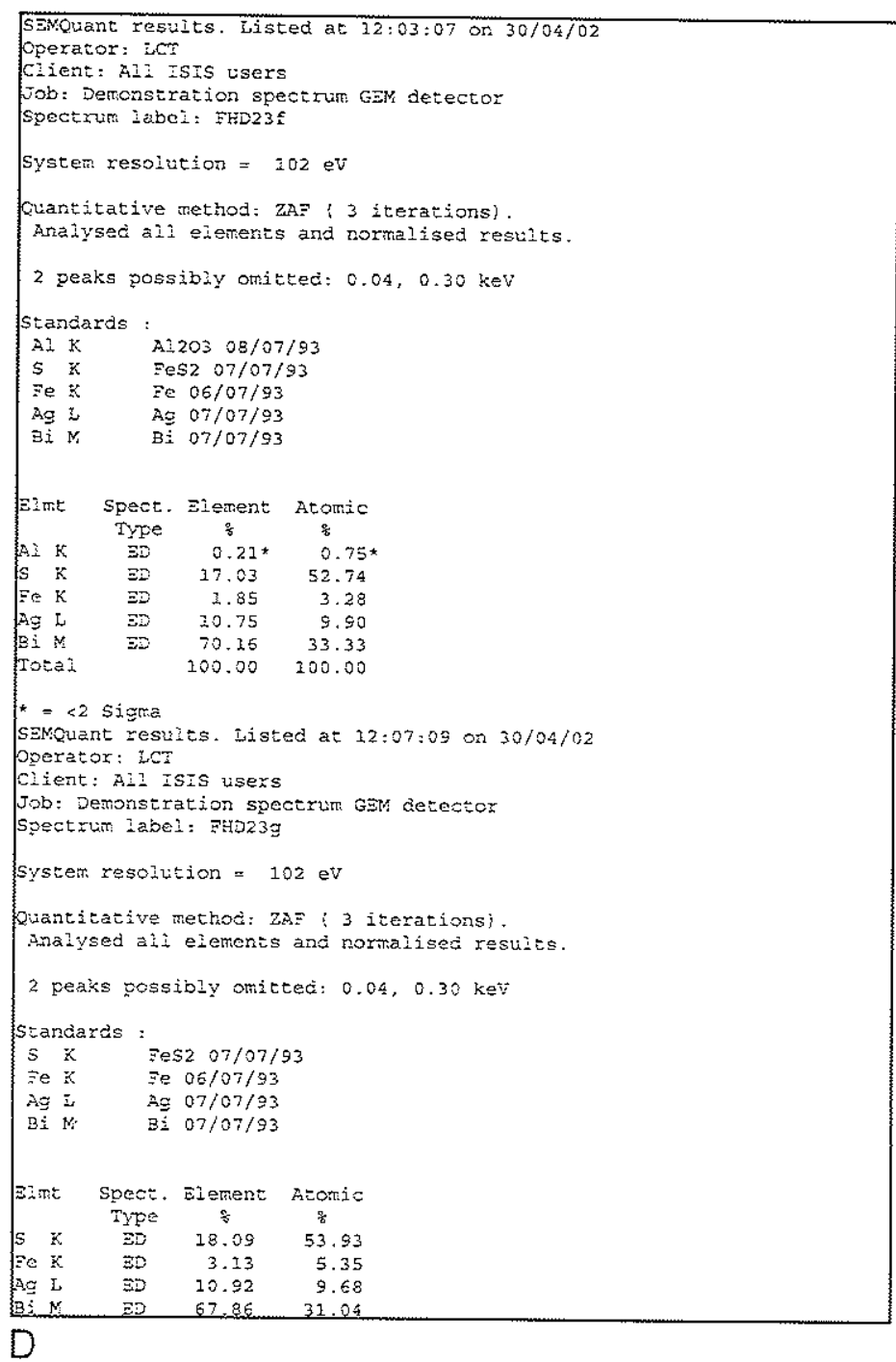




\section{c. Pirita}

A pirita é o mineral mais abundante, aparece em todos os setores (Echandia, Cien Pesos e Marmato Bajo); aparentemente existem dois eventos de formação de pirita, já que são observadas piritas euedrais de granulação mais fina (Py2) que substituem as piritas anteriores (Py1). Pirita substitui a pirrotita (amostras FHD-14, FHD19b, FHD-22 e FHD-23); é substituída pelos outros mineras. No setor de Echandía a pirita é substituída por esfalerita (amostra FHD-2) e por galena (López-Rendón, 1991; López Rendón e Bedoya, 1989), aparece intercrescida com arsenopirta (López-Rendón e Bedoya, 1989), e também Py2 substitui a galena (amostra FHD-2, FHD-7). No setor de Cien Pesos, pirita é substituída por esfalerita e intercrescida com arsenopirita (Medina, 1989; Restrepo, 1989). No setor de Marmato Bajo, segundo Bedoya (1998) a pirita do primeiro evento (Py1) é substituída por todos os outros minerais (excetuando a pirrotita) e foi afeitada por um evento de deformação junto com a esfalerita; já a pirita do segundo evento (Py2) é de granulação fina e apresenta formas euédricas, subédricas e foi depositada após o evento de deformação e está associada a calcita e clorita (Figura, $24,25,26)$.

\section{d. Pirrotita}

A pirrotita foi encontrada em amostras dos setores de Cien Pesos (FHD-14) e Marmato Bajo (FHD-19b, FHD-22, FHD23), aparece como acessório dentro de pirita, é substituída pela pirita e calcopirita (amostra FHD-22). No setor de Echandia, LópezRendón (1991) menciona pirrotita em menor quantidade e associada ao ouro. No setor de Cien Pesos, segundo Medina (1989) e Restrepo (1989) a pirrotita está intercrescida com calcopirita. No setor de Marmato Bajo, a pirrotita é o segundo mineral em abundância, e o primeiro na seqüência paragenética sendo substituído por todos os outros minerais (Bedoya, 1998) (Figura 25, 26). 


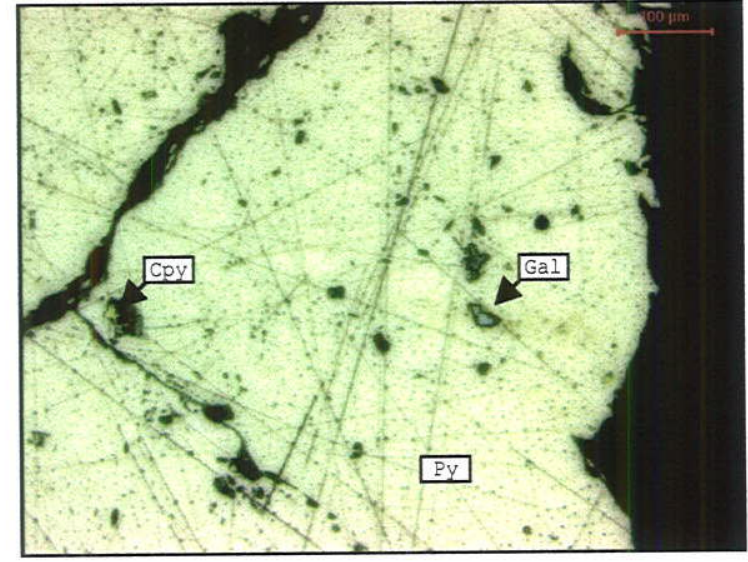

A

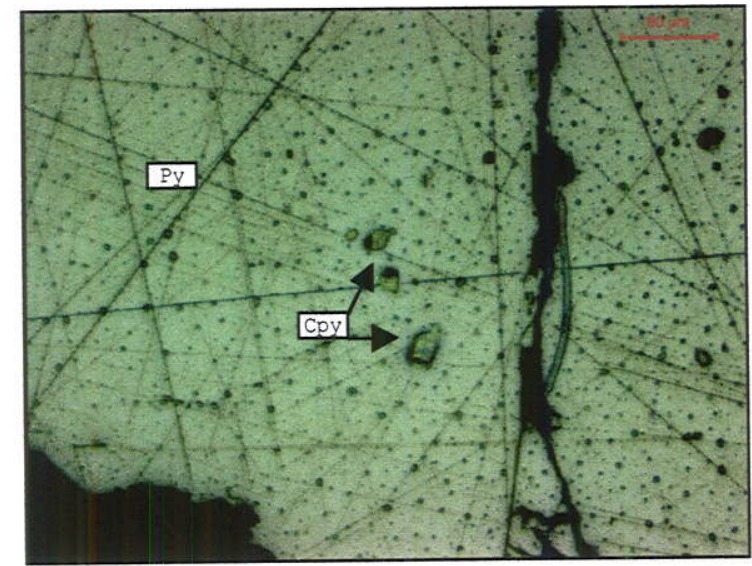

C

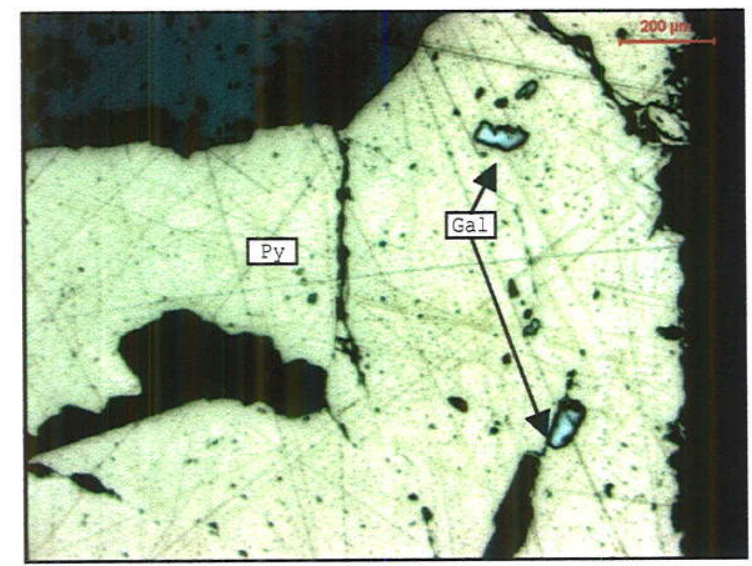

B

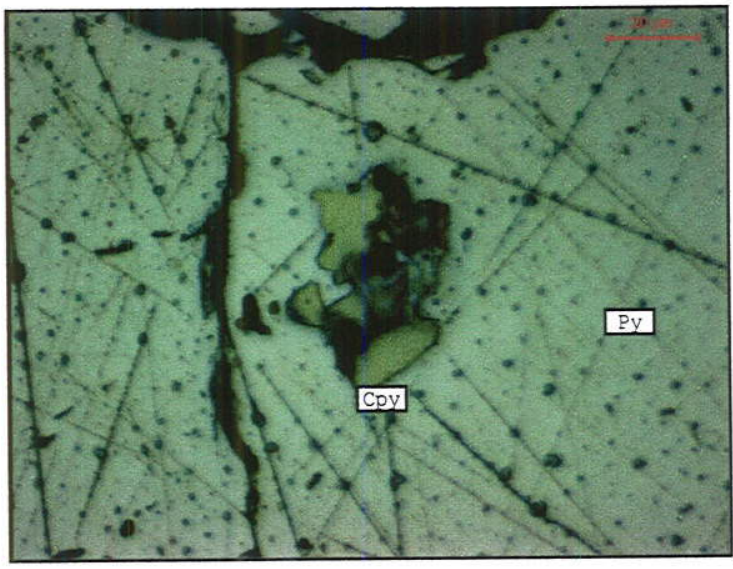

D

Figura 24. Amostra FHD19, imagem no microscópio de luz refletida. A-B) Pirita (Py) fraturada com microcristais de galena (Gal) e calcopirita. C-D) Microcristais de calcopirita substituindo a pirita. 


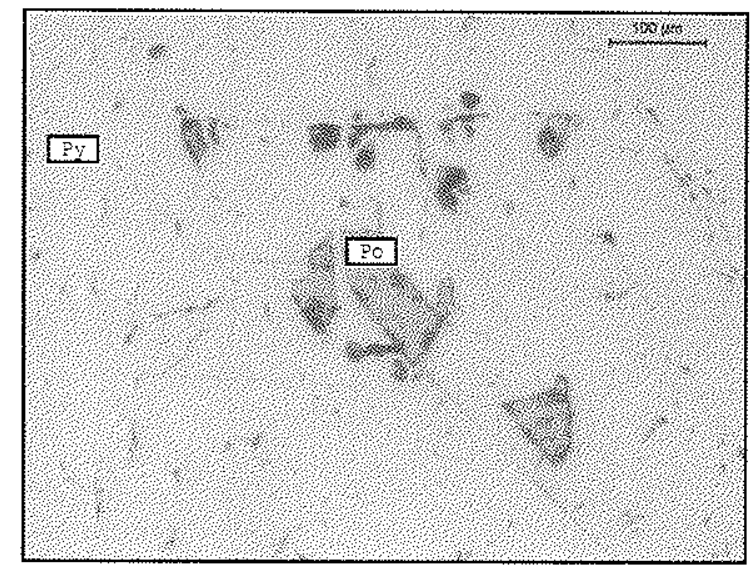

A

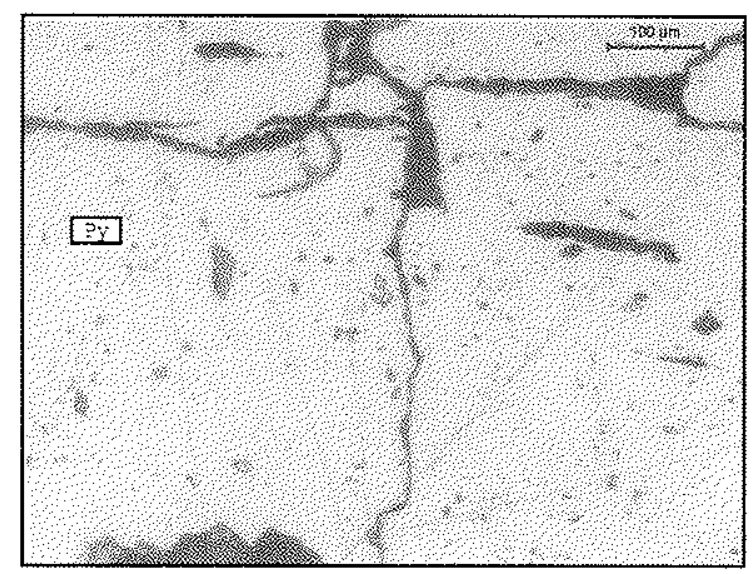

C

Figura 25. Amostra FHD14, Imagem no microscópio de luz refletida. A e B) Pirrotita (Po) dentro de pirita (Py); pirita substitui a pirrotita. C) Pirita fraturada com microcristais de calcopirita, galena e esfalerita. D) Pirita 2 (Py2), substitui a pirita 1 (Py1).

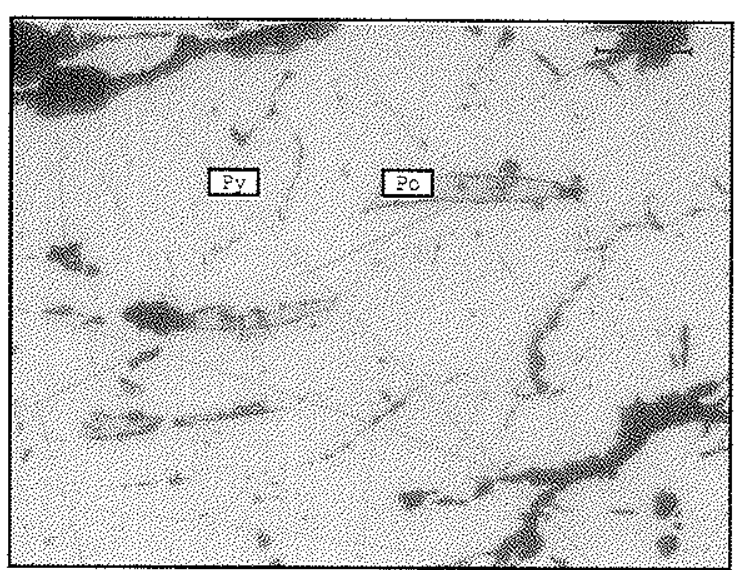

B

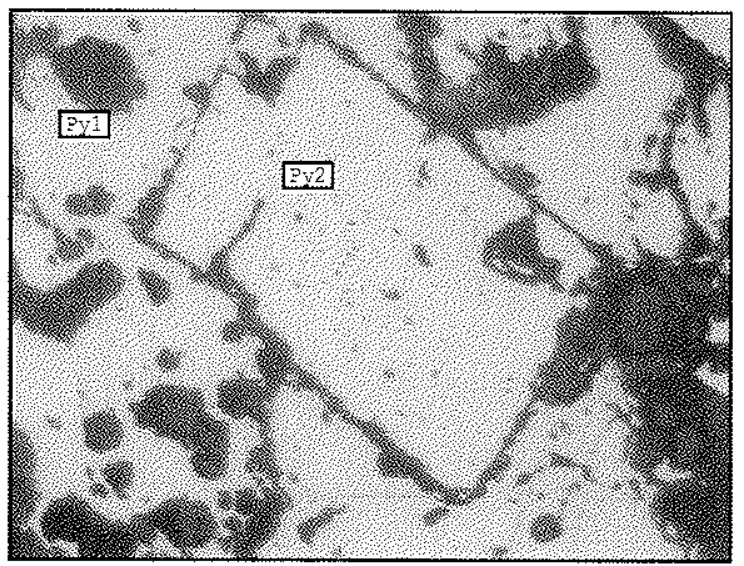

D 


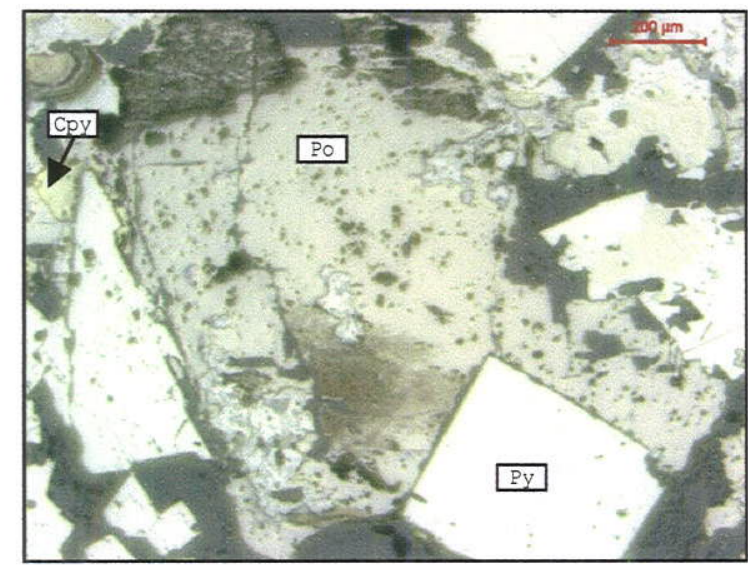

A

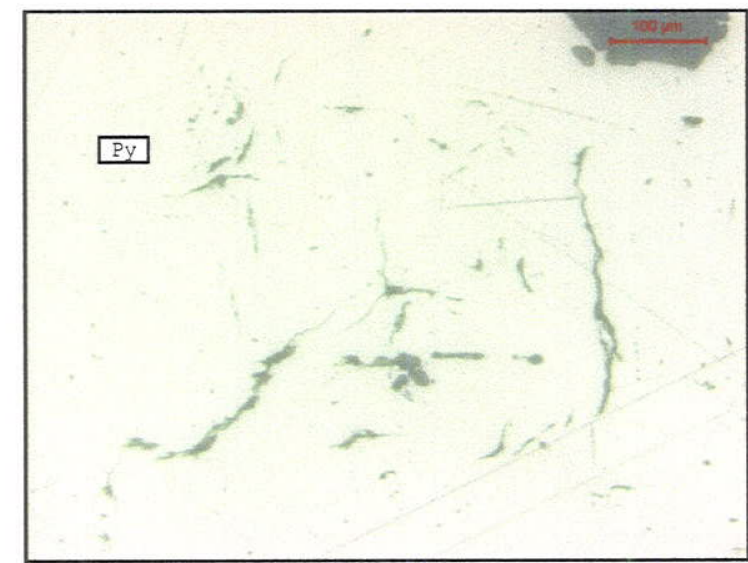

C

Figura 26. Amostra FHD22, Imagem no microscópio de luz refletida. A e B) Pirrotita (Po) substituída por pirita (Py2) e calcopirita (Cpy); pirita substituída por calcopirita. C) Pirita fraturada. D) Pirita com microcristal de calcopirita.

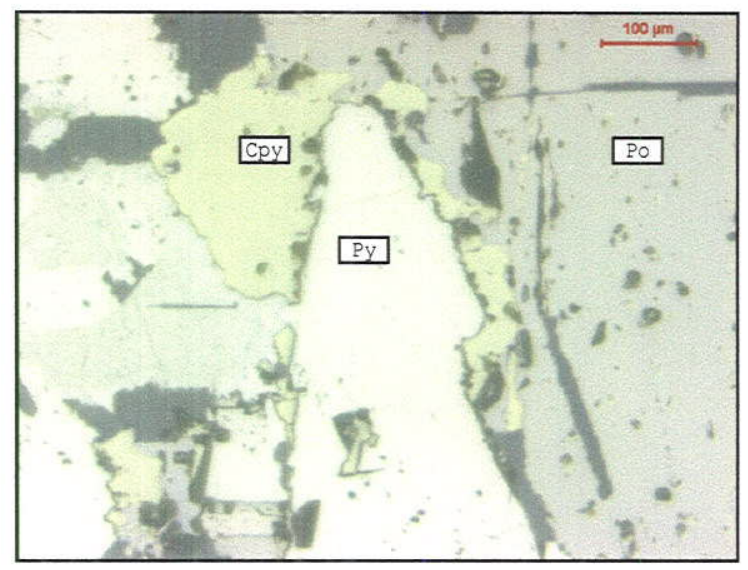

B

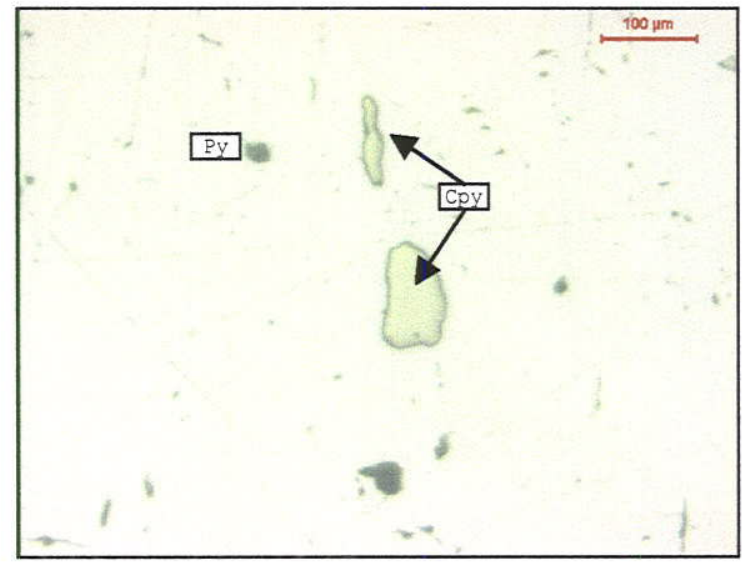

D 


\section{e. Galena}

Galena é um mineral que foi encontrado nos três setores (amostras FHD-2, FHD7, FHD-14, FHD-19, FHD-21, FHD-22, FHD-23), alguns das galenas são argentiferas. No setor de Echandia, galena substitui a pírita (López-Rendón, 1991; López-Rendón e Bedoya, 1989), também é substituída por pirita (amostra FHD-2 e FHD7). No setor de Cien Pesos se encontra como pequenos cristais dentro de esfalerita (amostra, FHD-14). No setor de Marmato Bajo, galena apresenta-se como pequenos microcristais dentro de pirita substituindo-a (amostra FHD-21), assim com em fraturas associadas a prata, teluretos e sulfossais de Bi (amostra FHD-23); segundo Bedoya (1998), no setor de Marmato Bajo a galena é um mineral acessório, pode-se observar dentro de pirita ocupando espaços intersticiais, substituindo esfalerita, intercrescida e substituindo a calcopirita e substituindo a arsenopirita.(Figura 27, 28, 29).

\section{f. Arsenopirita}

Arsenopirta só foi observada na amostra FHD-2, sua relação não é muito clara, mas parece substituir e estar intercrescida com pirita. Arsenopirita é de pouca abundância e está intercrescida com pirita no setor de Echandia (López-Rendón e Bedoya, 1989) e no setor de Cien Pesos (Medina, 1989). No setor de Marmato Bajo, segundo Bedoya (1998) a arsenopirita é o mineral que segue em abundância a pirita e pirrotita; se pode observar substituindo e intercrescida com pirita, e intercrescida com esfalerita (Figura 30).

\section{g. Esfalerita}

A esfalerita é um mineral abundante, foi encontrada nos setores de Echandía (amostra FHD-2, FHD-7), Cien Pesos (amostras FHD-14, FHD-15, FHD-17) e Marmato Bajo (amostra FHD-19, FHD-21). 

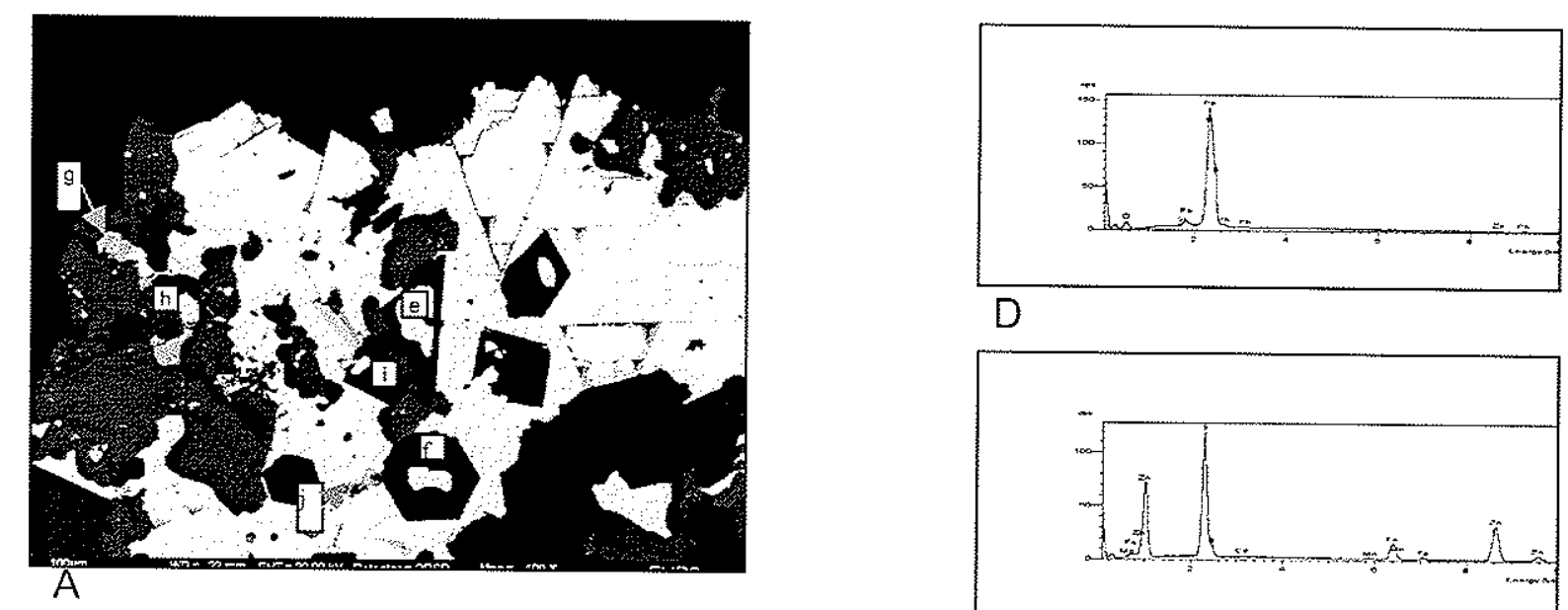

$\mathrm{D}$
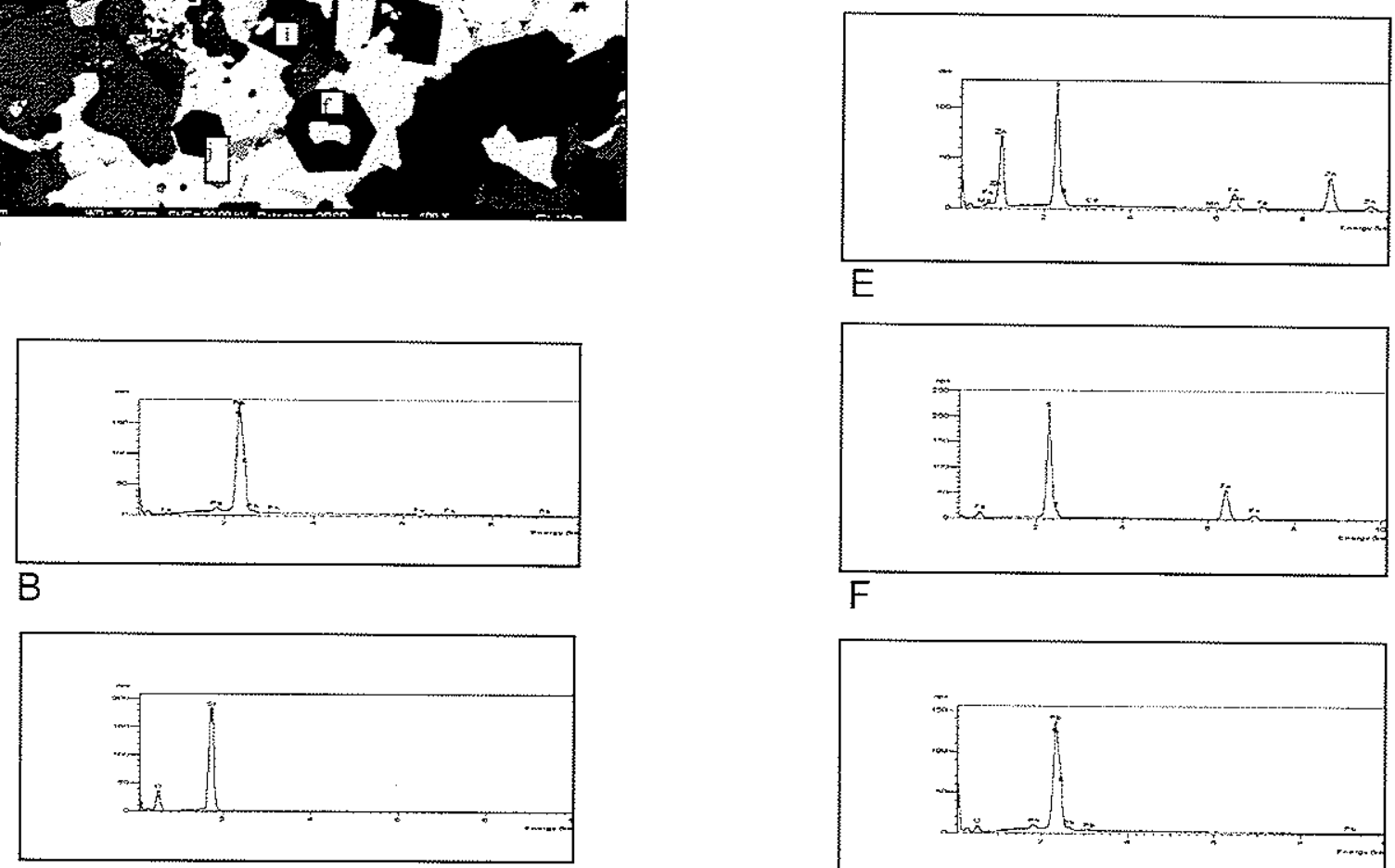

C

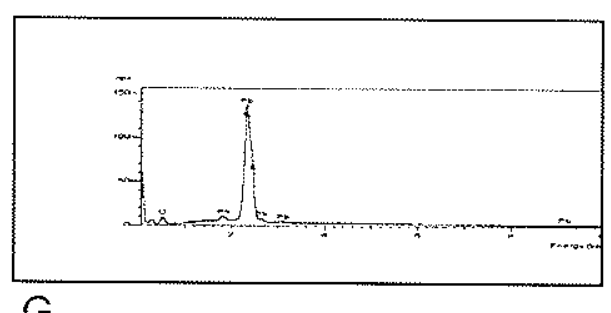

Figura 27. Amostra FHD2. A) Galena (e) substituída por quartzo (f), pirita2 (i), esfalerita (h) e mineral formado a partir da galena ( $\mathrm{e} \mathrm{g}$ ) (Imagem EDS). B) Espectro da galena. C) Espectro do quartzo. D e G) Espectro do mineral formado a partir de galena. E) Espectro da esfalerita. F) Espectro da pirita. 


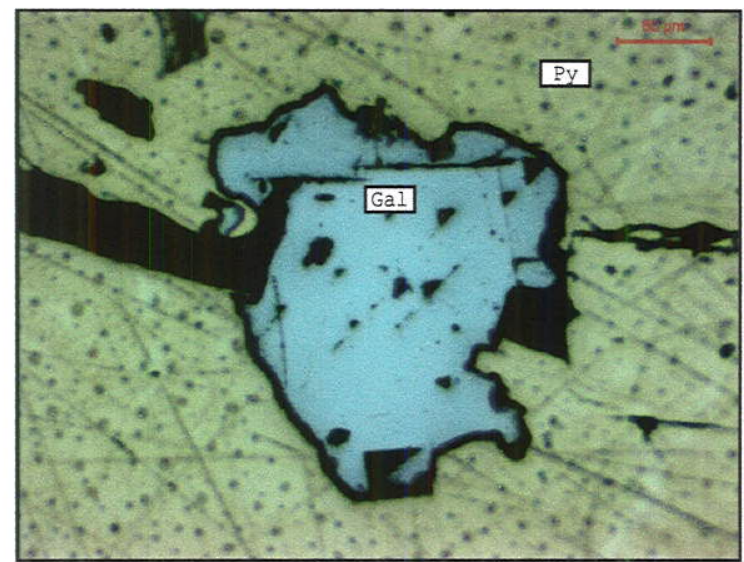

A

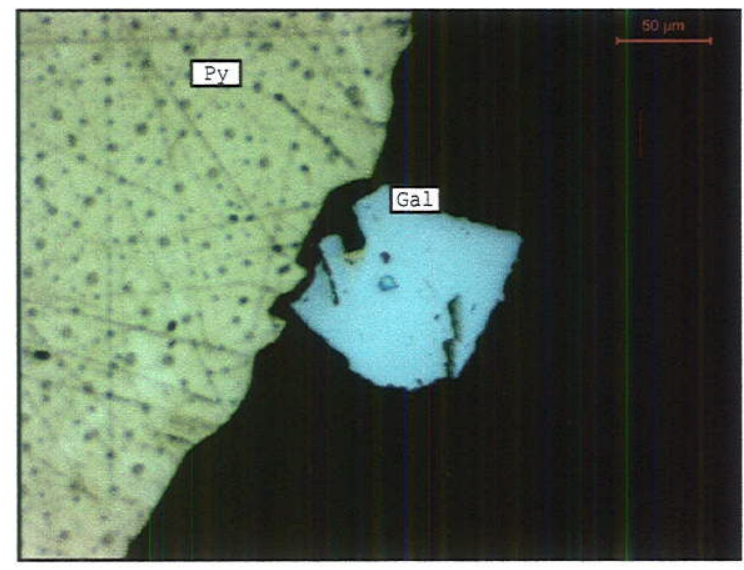

C

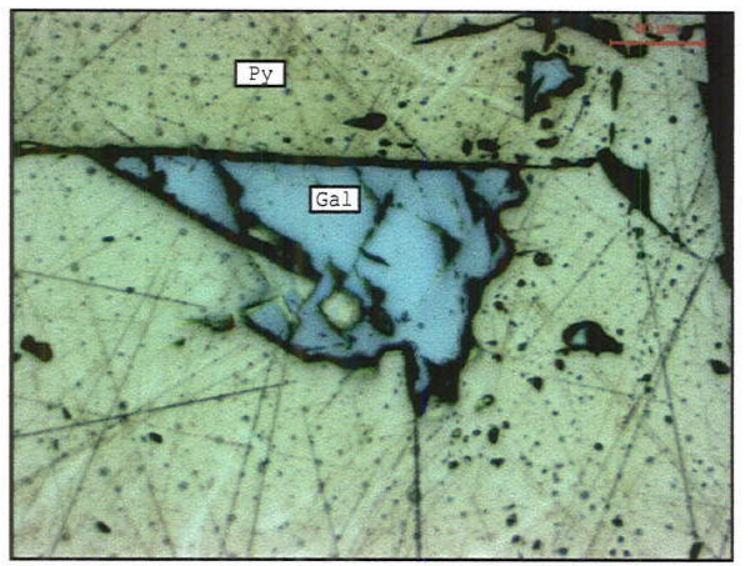

B

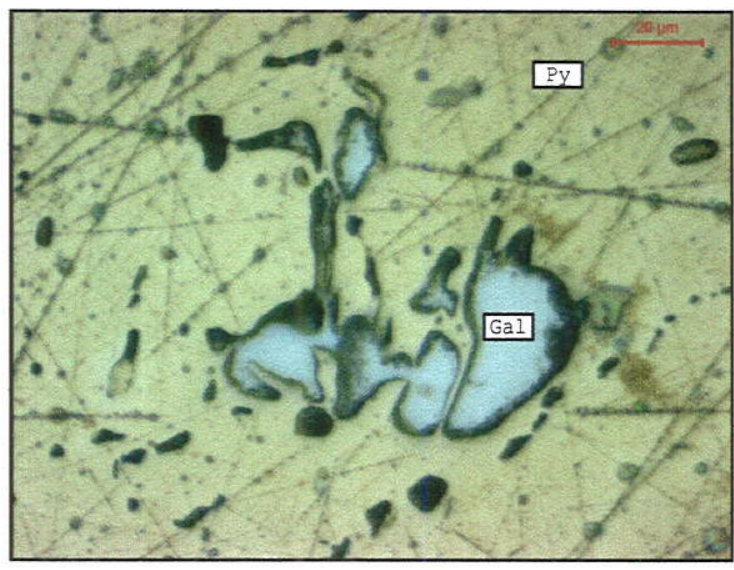

D

Figura 28. Amostra FHD21, imagem no microscópio de luz refletida. A, B e C) Microcristais de Galena (Gal) em fraturas de Pirita (Py). D) Galena intersticial em Pirita. 


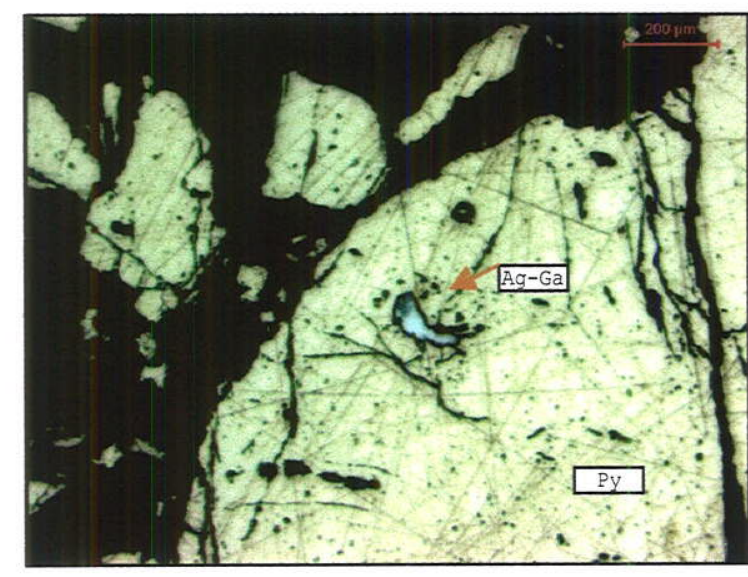

A

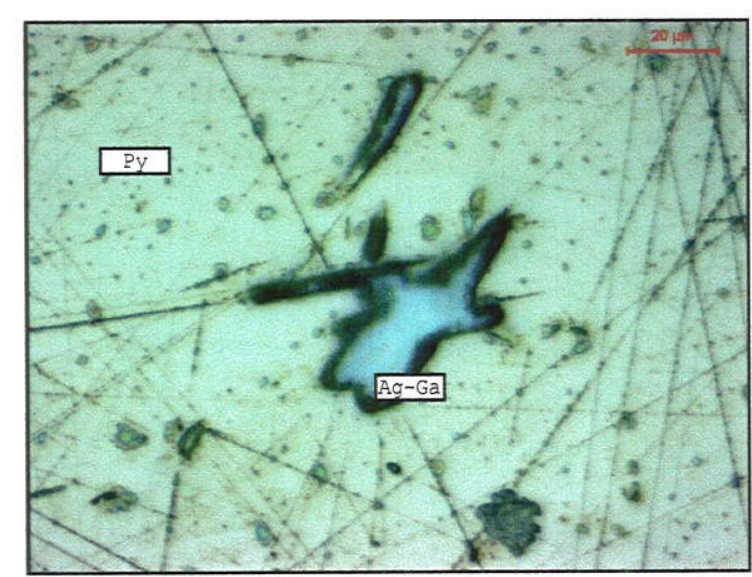

C

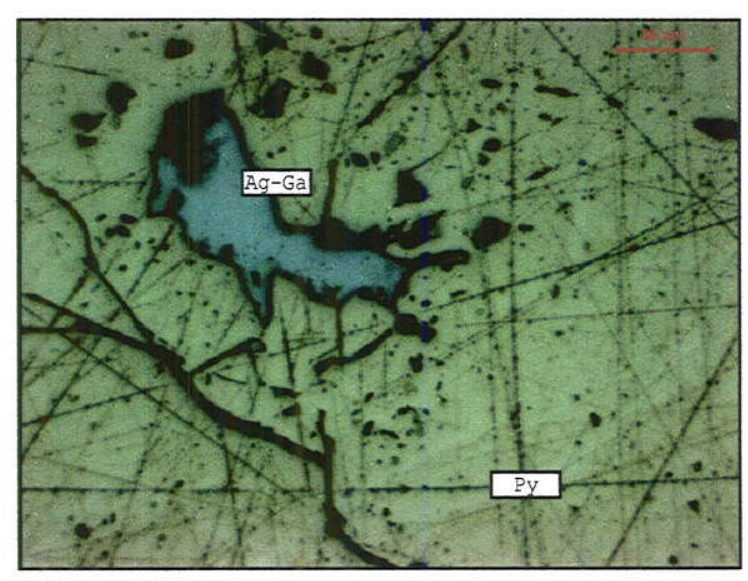

B

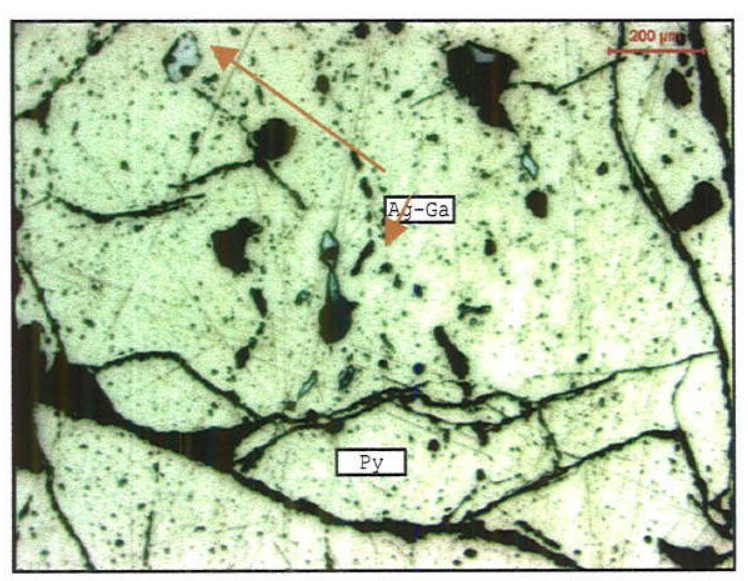

D

Figura 29. Amostra FHD23, imagem no microscópio de luz refletida. Galenas argentíferas (Ag$\mathrm{Ga}$ ) dentro de piritas (Py) fraturadas. 


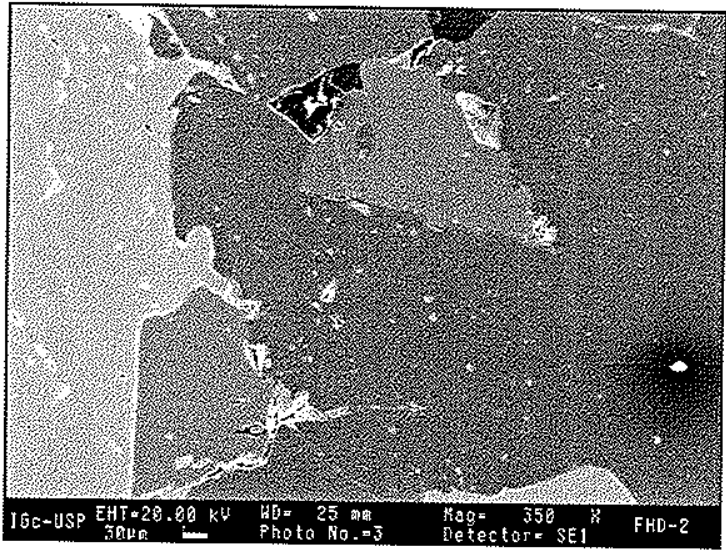

A

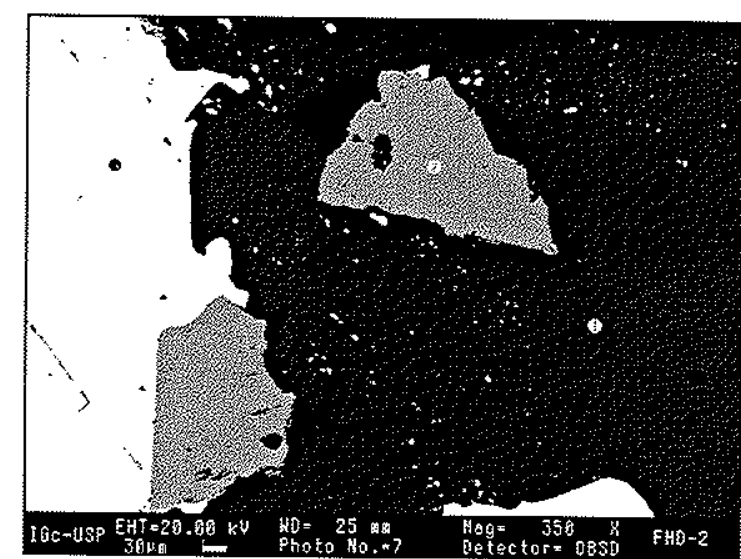

B
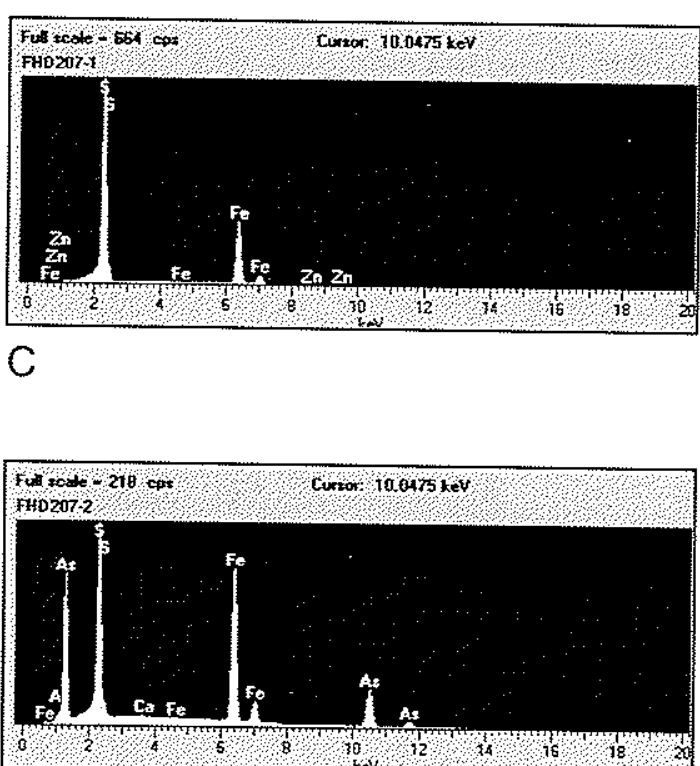

$\mathrm{D}$

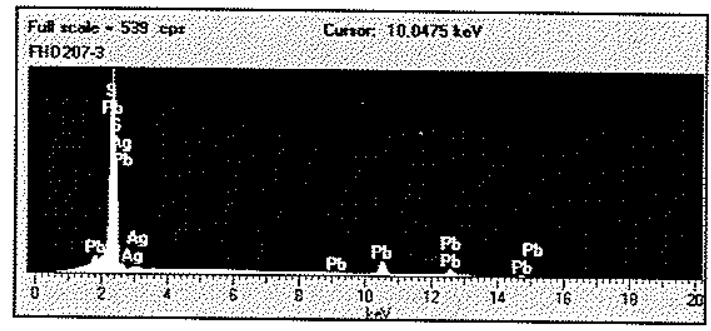

E

Figura 30. Amostra FHD-2, Pirita (1), Arsenopirita (2) e Galena (3); Arsenopirita corta pirita e galena, microcristais de galena dentro de pirita. A)Imagem ES no MEV, B) Imagem EDS no MEV, C) Espectro da pirita, D) Espectro da Arsenopirita, E) Espectro da Galena. 
Foi observada uma relação importante entre calcopirita e esfalerita; a calcopirita aparece intercrescida com esfalerita (amostra FHD-19), e também como abundantes microglóbulos dentro de esfalerita em todas as amostras. Esfalerita substitui a pirita e galena (amostra FHD-2). No setor de Echandía, segundo López-Rendon (1991) a esfalerita é abundante e substitui a pirita e galena . No setor de Cien Pesos, segundo Medina (1989) e Restrepo (1989), esfalerita substitui a pirita. No setor de Marmato Bajo, Segundo Bedoya (1998) a esfalerita e abundante localmente, geralmente forma bandas com pirita; também menciona que esfalerita substitui a pirrotita e arsenopirita. Na amostra FHD-19, observou-se esfalerita substituindo galena, pirita e intercrescida com calcopirita (Figura 31).

\section{h. Calcopirita}

Calcopirita é um mineral comum, mas no abundante nos três setores. É de forma anédrica, e substitui a: pirrotita (amostra FHD-22), pirita (amostra FHD 19), galena (amostra FHD-2, FHD-19); está intercrescido e como microglóbulos dentro de esfalerita; microveios de esfalerita cortam a esfalerita (amostra FHD-19). Segundo Bedoya (1998), no setor de Marmato Bajo, é um mineral acessório e apresenta-se em poucas quantidades; substitui a arsenopirita, pirrotita e esfalerita; está associado com calcita.

\section{i. Marcasita}

Bedoya (1998), menciona a presença de Marcasita no setor de Marmato Bajo, os cristais são euédricos e de granulação fina, estão intercrescidos com Py2.

\section{j. Adularia}

Segundo Rossetti et al. (1999), as associações minerais mais importantes nas mineralizações de Marmato são de dois tipos. O primeiro constituído por adularia, pirita e menos abundante calcita e quartzo; o segundo está constituído por calcita, quartzo e sulfetos. 


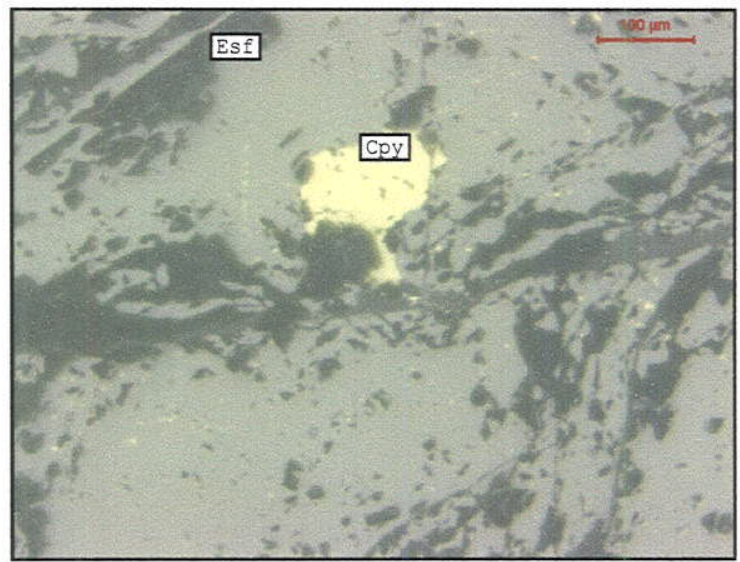

A

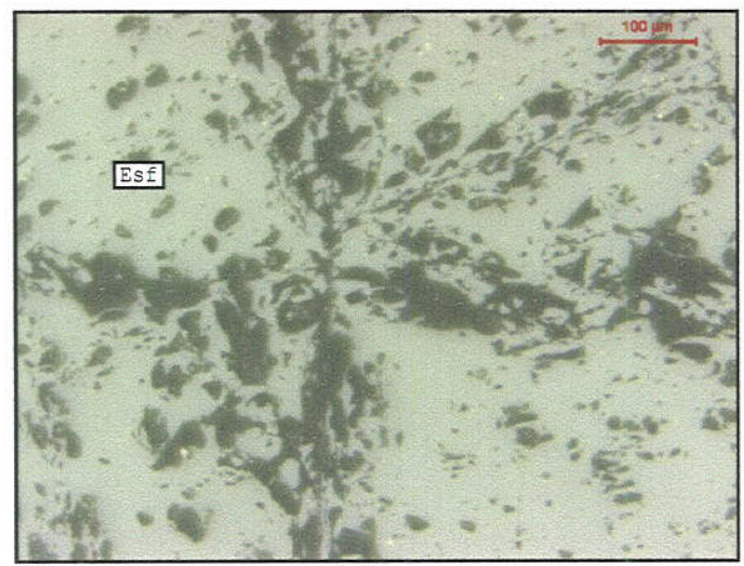

C

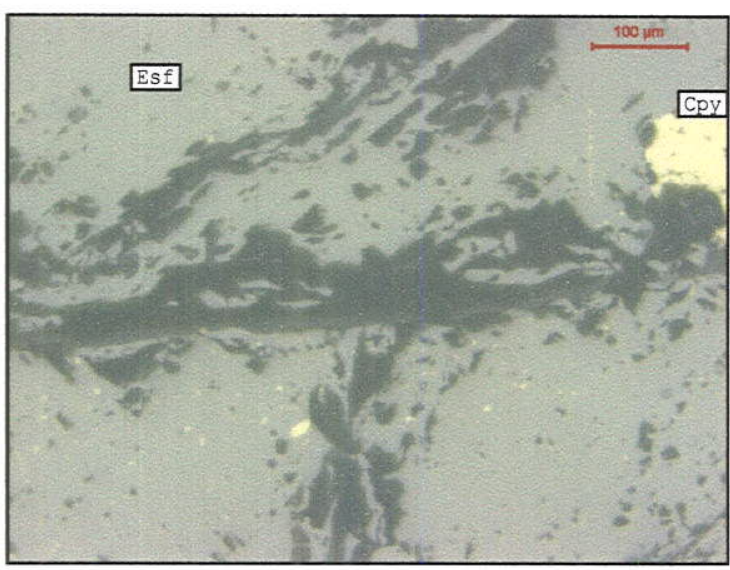

B

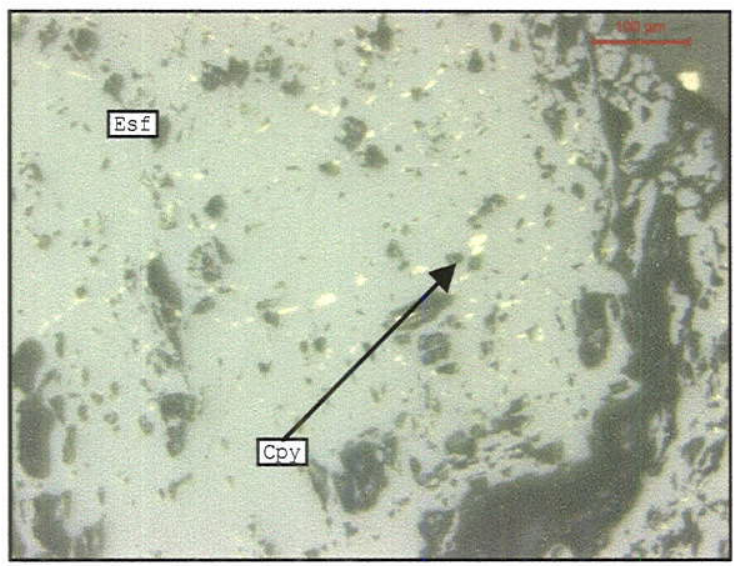

D

Figura 31. Amostra FHD19, Imagem no microscópio de luz refletida. A e B) Esfalerita (Esf) fraturada, com calcopirita (Cpy). C) Esfalerita fraturada. D) Esfalerita fraturada com microglóbulos de calcopirita. 


\section{k. Ganga}

Os minerais de ganga são constituidos por abundante carbonato e em menor quantidade quartzo. Segundo López-Rendón (1991) e López-Rendón e Bedoya (1989) no setor de Echandía o carbonato é o material de ganga dominante, é foi depositado após a formação dos sulfetos, também se apresenta em brechas hidrotermais mineralizadas; o quartzo é de menor abundância. Bedoya (1998) no setor de Marmato Bajo, menciona calcita presente em toda a seqüência paragenética, e quartzo e clorita subordinados.

\section{Outros}

Os sulfetos encontram-se fraturados, algumas fraturas estão preenchidas de argilominerais, carbonatos e quartzo. Como minerais supergênicos se encontram, entre outros: goethita, hematita, zincita, malaquita, azurita e gipso (López-Rendón, 1991).

\subsubsection{Paragênese mineral}

Para explicar a paragênese mineral tem sido propostas três fases principais de formação dos sulfetos: a primeira fase (F1) foi dominada por abundante pirita, a segunda (F2) foi dominada por esfalerita, a terceira (F3) foi dominada por pirita tardia (Py2) e carbonato; existindo uma quarta etapa de alteração supergênica. Segundo Bedoya (1998), no setor de Marmato Bajo, registrou-se um evento de deformação no limite entre a 2 e a 3 fase; no mesmo limite, registrou-se um evento de formação de brechas, no setor de Echandía (López-Rendón e Bedoya,1989; López-Rendón, 1991).

$\mathrm{Na}$ primeira fase de formação dos sulfetos, no setor de Echandía esteve dominada por abundante pirita, em menor proporção arsenopirita; na parte intermedia da F1 aparece galena, ouro (electrum), prata; na parte final da F1 aparece pirrotita, esfalerita e calcopirita (López-Rendón e Bedoya,1989; López-Rendón, 1991). No setor de Cien Pesos, a F1 foi dominada por abundante pirita, na parte intermediaria da F1 por 
ouro e na parte final da F1 por esfalerita (Medina, 1989; Restrepo, 1989). No setor de Marmato Bajo, a F1 esteve dominada pela formação de abundante pirita associada a carbonato, e também por pirrotita que foi anterior à formação de pirita, e na parte final da F1 aparece arsenopirita. Ouro também se formo na F1.

$\mathrm{Na}$ fase de formação intermediaria dos sulfetos, esteve dominada pela formação de abundante esfalerita, associada a calcopirita. No setor de Echandia, a depositação de esfalerita foi abundante, em menor proporção: galena, calcopirita, pirrotita, argentita, prata e ouro; na parte final da F2, esfalerita se associa com pirita tardia (López-Rendón e Bedoya,1989; López-Rendón, 1991). No setor de Cien Pesos, a formação de esfalerita foi abundante, na parte intermedia da F2, aparece calcopirita associada a pirrotita e na parte final quartzo e carbonato; ouro também se forma na F2 (Medina, 1989; e Restrepo, 1989). No setor de Marmato Bajo, a F2 foi formada por esfalerita associada a calcopirita, ao inicio da F2 é formada arsenopirita; ganga e ouro também se forma naF2 (Bedoya, 1998).

A Fase tardia (F3), no setor de Echandía, formou-se pirita (Py2) e em menor abundância: esfalerita, calcopirita, prata, argentita, ouro (a formação de ouro e prata foi importante); na F3 são importantes as brechas hidrotermais com precipitação de calcita, e quartzo subordinado (López-Rendón e Bedoya,1989; López-Rendón, 1991). No setor de Cien Pesos, foi importante a formação de brechas hidrotermais com precipitação de carbonato e menor quartzo (Medina, 1989). No setor de Marmato Bajo, na F3, foi depositada pirita de granulação fina, galena, polybasite, marcasite, ouro, quartzo, carbonato, clorita (Bedoya, 1998) (Figura 32).

\subsubsection{ALTERAÇÃO HIDROTERMAL}

A alteração hidrotermal está restrita às unidades vulcânicas, sendo reconhecidos dois principais estilos de alteração: propilitização e sericitização, embora localmente possa também existir silicificação, argilização e albitização. 


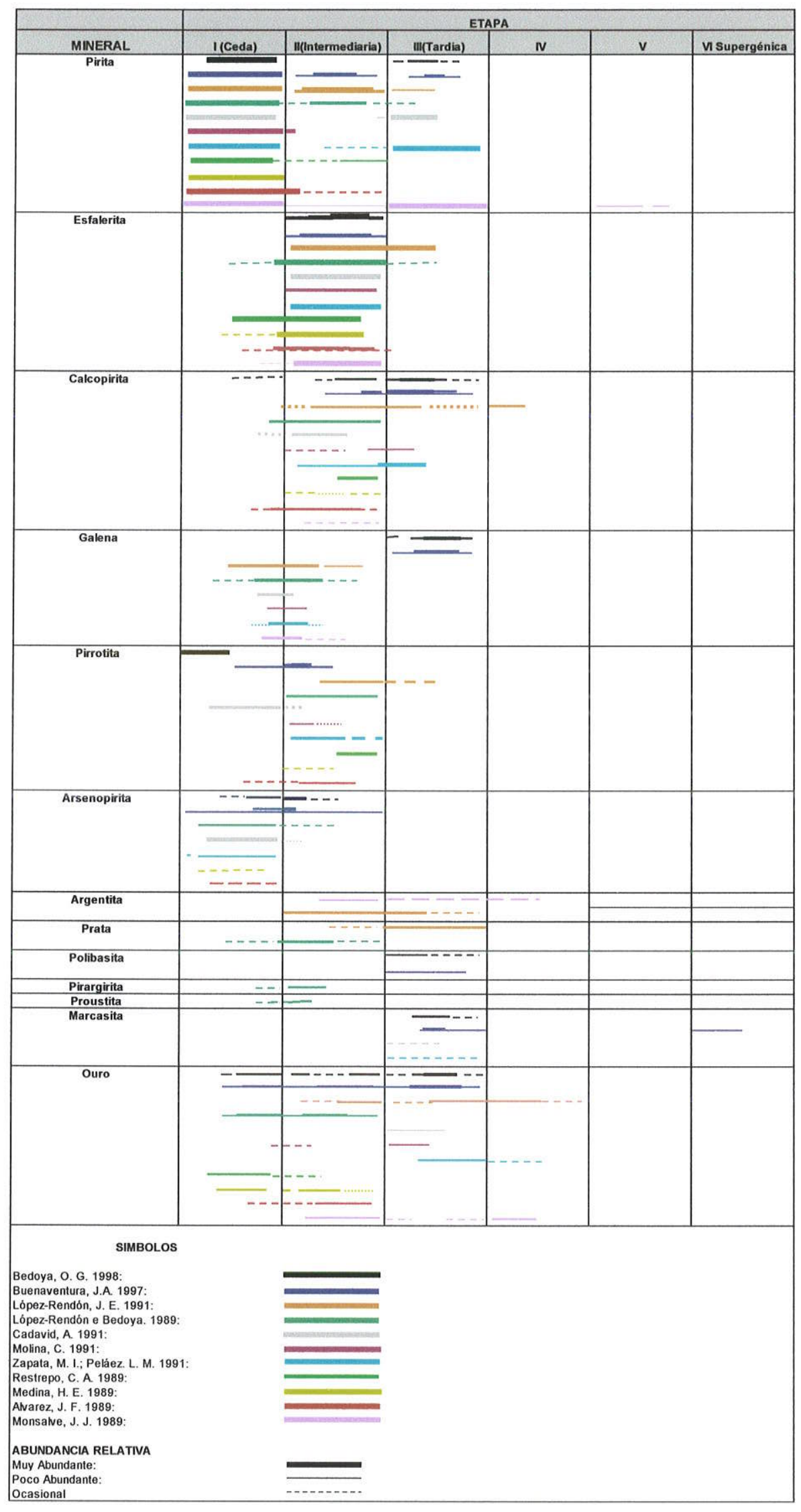

Figura 32a. Paragênese mineral proposta por diferentes autores para as minas do Distrito de Marmato. 


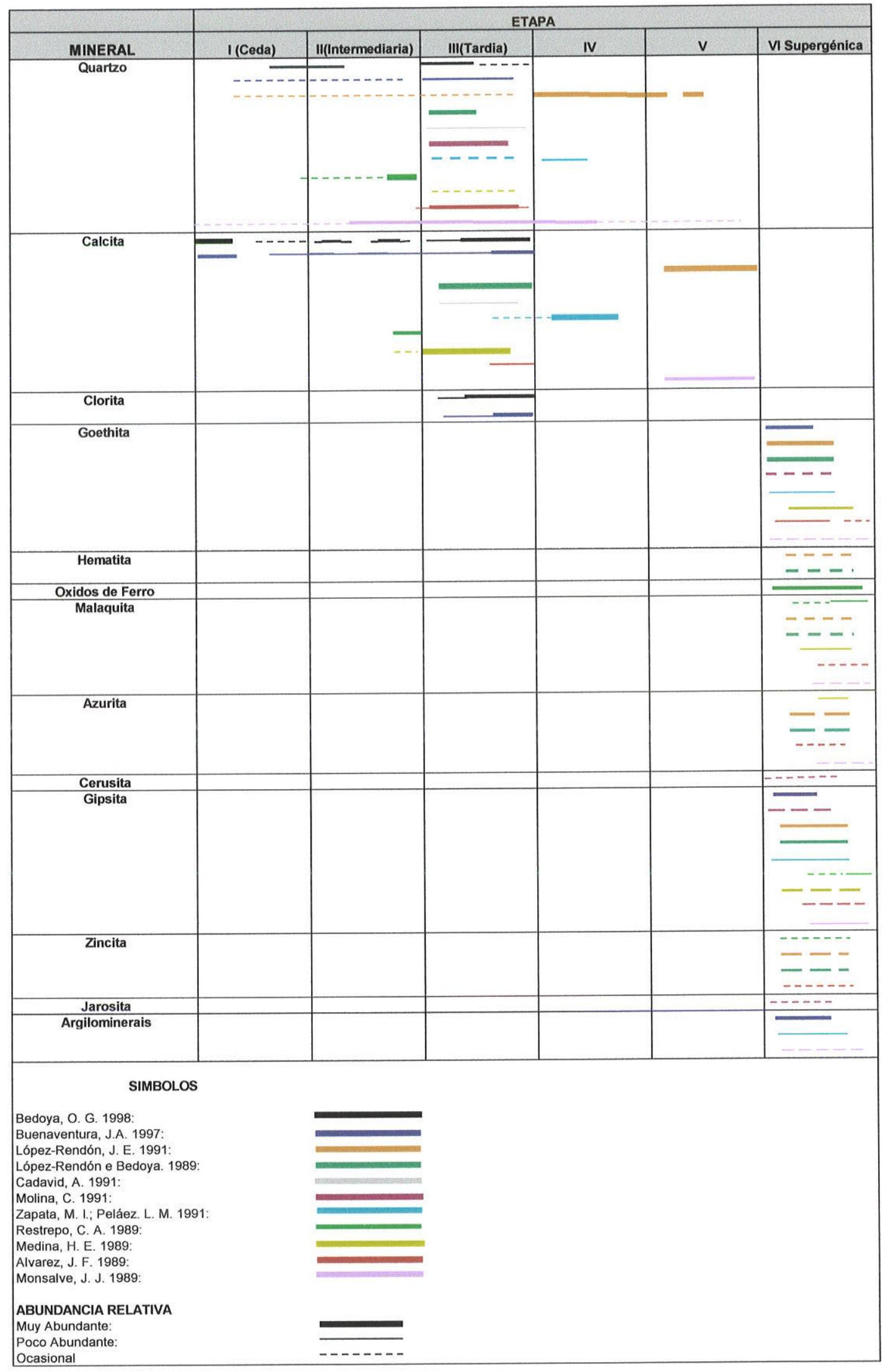

Figura 32b. Paragênese mineral proposta por diferentes autores para as minas do Distrito de Marmato 


\subsubsection{Propilitização}

Esta é a alteração inicial, afeta amplas áreas e não está restrita aos veios já que afeta tanto o dacito pórfiro quanto o andesito pórfiro (amostras FHD-4, FHD-5, FHD-20, FHD-24 e FHD-28).

Os fenocristais de plagioclásio encontram-se substituídos levemente por sericita e carbonato a partir das bordas, fraturas e do núcleo; também ocasionalmente por epidoto. Os máficos, hornblenda e biotita, são substituídos principalmente por clorita e carbonato, as vezes por epidoto e localmente opacos; segundo López-Rendon (1991), López-Rendon e Bedoya (1989) os minerais ferromagnesianos são substituidos por clorita e calcita através de planos de clivagem e de forma pervasiva e apresenta-se pirita em ferromagnesianos relacionada a clorita. A magnetita primaria ainda é conservada e a matriz é formada por um agregado de granulação fina composto por quartzo, clorita, carbonato, sericita e isolada apatita.

O epidoto pode apresentar uma zonação vertical, no setor de Echandía (parte superficial) é pouco comum, encontra-se como cristais pequenos e isolados no andesito pórfiro na mina Plata Fría e segundo López-Rendon (1991) ocorrem de forma ocasional epidoto-zoicita e clinozoicita no Nivel Aguaceral. Já no setor de Marmato bajo o epidoto é encontrado como agregado dentro de plagioclásio, máfico e da matriz; também como cristais de até $1 \mathrm{~mm}$ substituindo plagioclásio. Bedoya (1999), divide essa alteração no setor de Marmato Bajo nas associações minerais: Clorita-Calcita; Epidoto-Clorita; e Epidoto (Clorita-Calcita) (Figura 33).

Segundo Buenaventura (1997) e Rossetti et al. (1999) a propilitizaçâo foi originada nos estados finais do resfriamento da atividade magmática formadora dos andesito-dacito pórfiros e não tem relação com a deposição de ouro . 


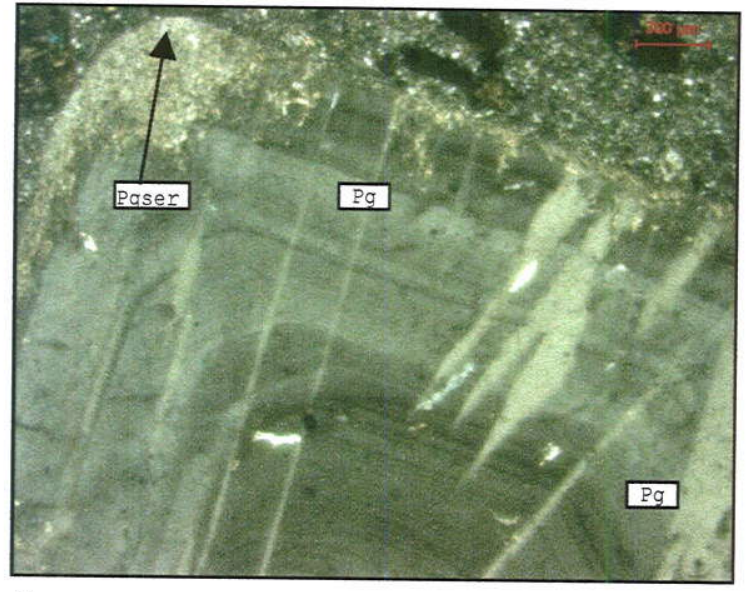

A

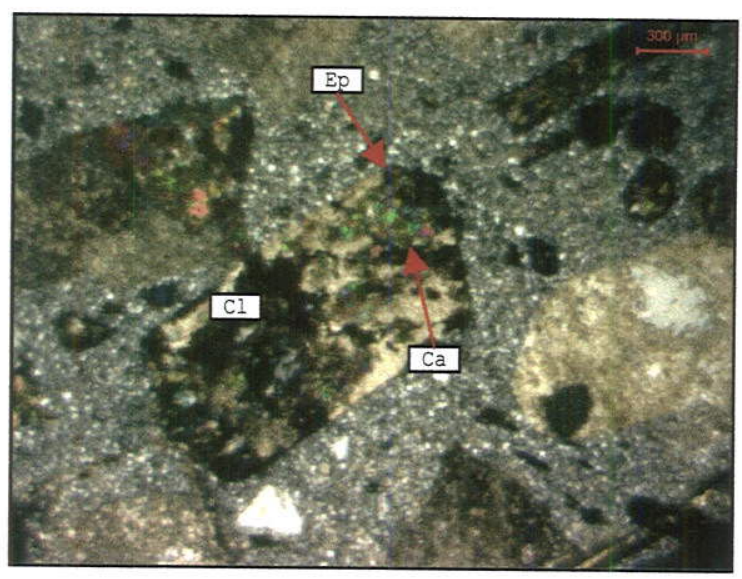

C

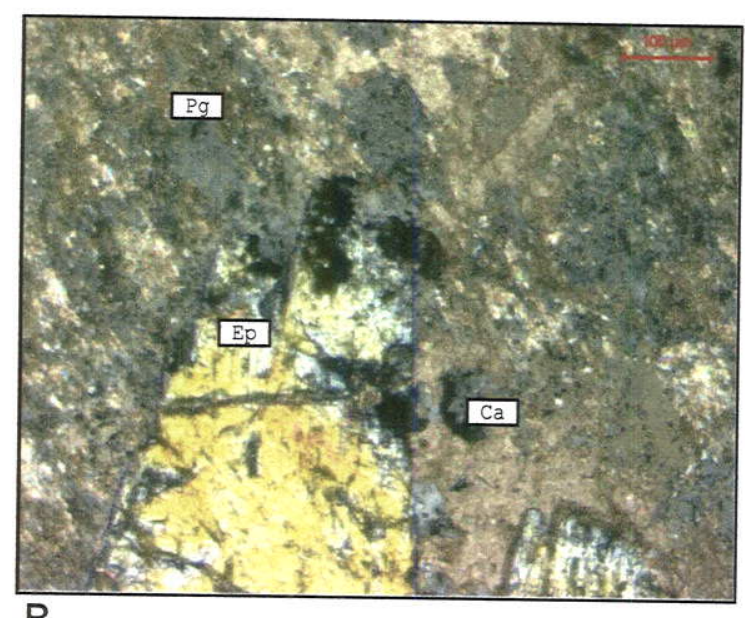

B

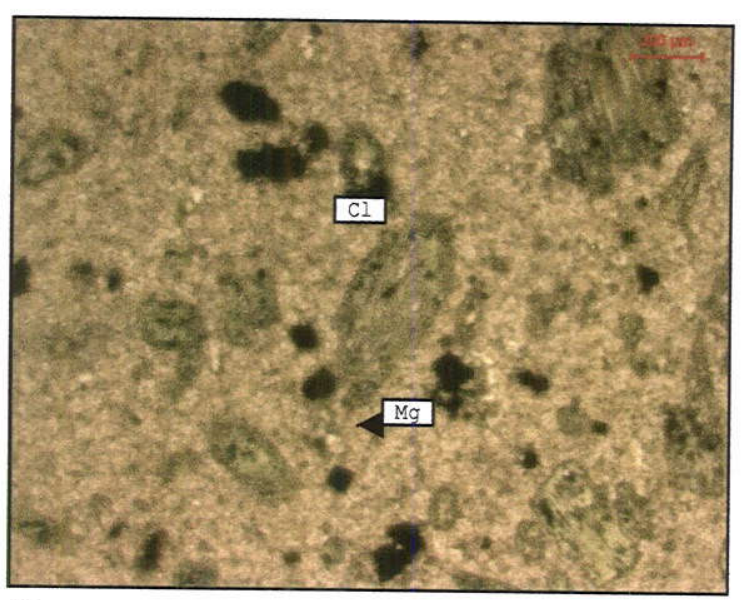

D

Figura 33. Propilitização, Imagem no microscópio de luz transmitida, A-B-C) amostra FHD-20 com nicóis cruzados. D) amostra FHD-4 com nicóis paralelos. A) Plagioclásio (Pg) zonado, levemente sericitizado (Pgser) nas bordas. B) Plagioclásio substituído por epidoto $(\mathrm{Ep})$ e carbonato $(\mathrm{Ca})$. C) Máfico substituído por clorita $(\mathrm{Cl})$, epidoto e carbonato. D) Máficos cloritizados e magnetita em matriz. 


\subsubsection{Sericitização}

A sericitização é comum nas rochas encaixantes perto aos veios, até 1 o $2 \mathrm{~m}$ (amostras FHD-2, FHD-7, FHD11, FHD-15, FHD-17, FHD-18 e FHD-24), afeta todos os minerais primários exceto o quartzo e a apatita: o plagioclásio encontram-se fortemente substituídos por sericita muito fina e subordinadamente por carbonato; os máficos por clorita e menor carbonato e as vezes sericita; o quartzo, caso a alteração seja forte, pode estar recristalizado nos bordes e ser substituído por sericita; a magnetita é totalmente substituída pela pirita; a matriz está composta principalmente por sericita e quartzo. Bedoya (1998), divide a alteração sericítica, no setor de Marmato Bajo em: Alteração sericítica forte, formada pelas associações: quartzo-sericita, sericita, sericitacarbonato. Alteração sericítica moderada, formada pelas associações: sericítica, sericita-carbonato, sericita carbonato subordinado. Alteração sericítica débil, formada pelas associações: sericítica, sericita-carbonato (Figura 34).

Segundo Rossetti et al. (1999), esta alteração é posterior à propilitização.

\subsubsection{Outras alterações}

A silicificação é importante só nas proximidades dos veios (amostras FHD-2 e FHD-7), caracteriza-se pela presença de quartzo de granulação fina em agregados policristalino formando: camadas, microveios ou substituindo os minerais principais; pode estar presente em menor proporção sericita e pirita (Figura 35).

Argilização é descrita no setor de Echandia (parte superficial) perto dos veios até 70 cm, segundo López-Rendon (1991) e López-Rendon e Bedoya (1989) apresenta altas concentrações de ouro; é composta por pirita não oxidada, esmectita, quartzo fino, clorita, sericita, plagioclásio e minerais supergênicos como malaquita e gipso.

Bedoya (1998), descreve albitização no setor de Marmato Bajo. 


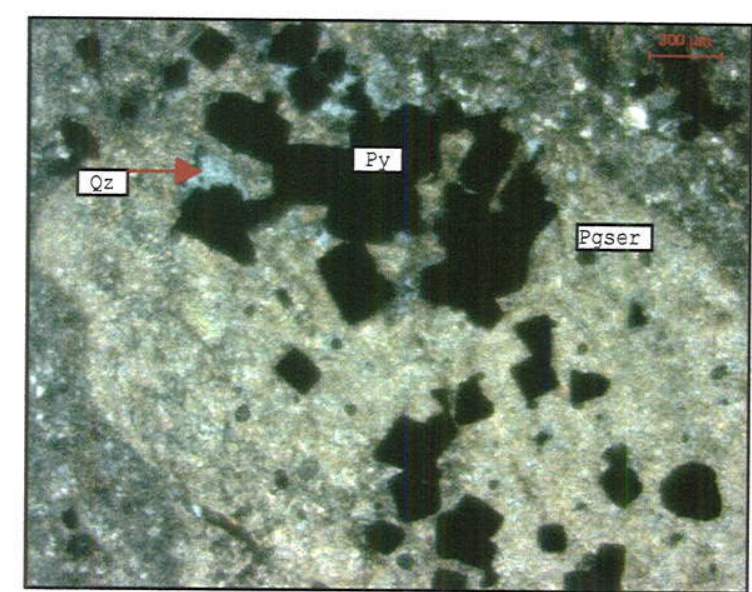

A

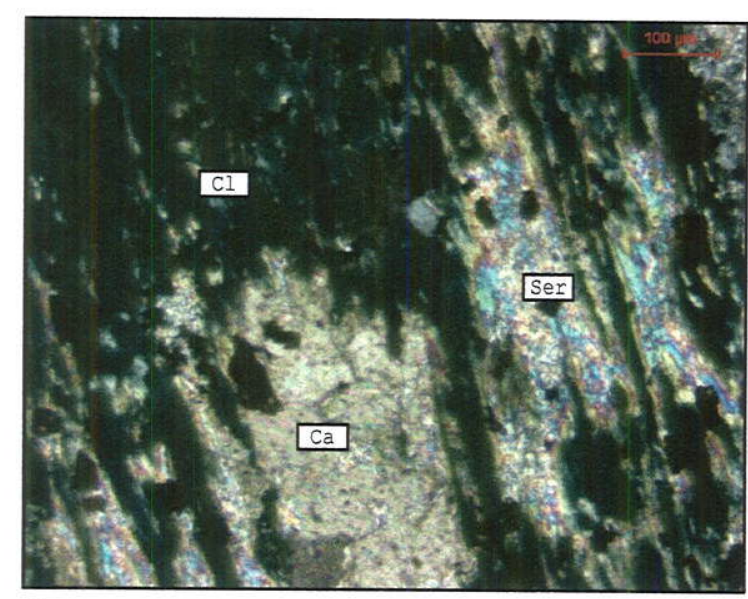

C

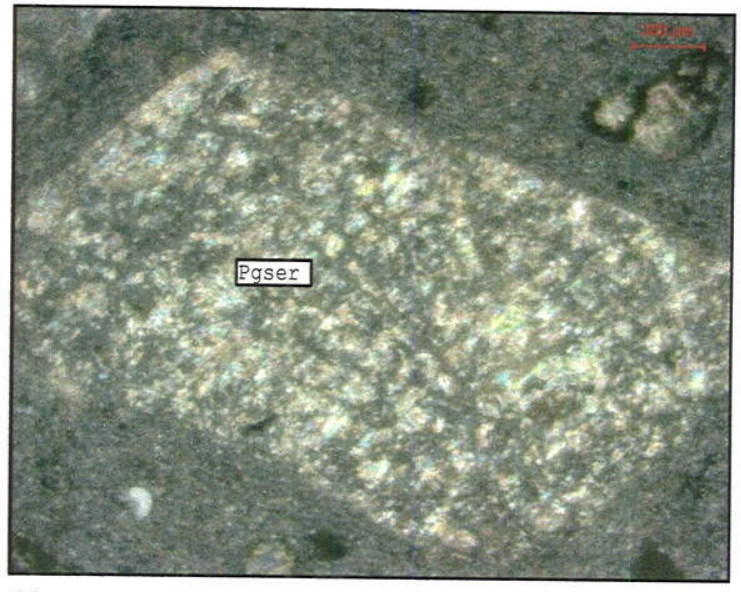

B

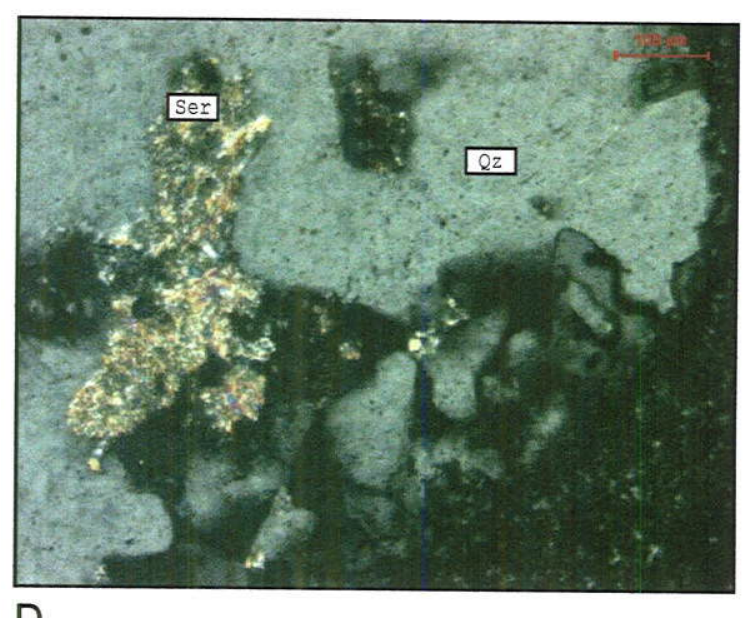

D

Figura 34. Sericitização, imagem no microscópio de luz transmitida, nicóis cruzados. A) Amostra FHD-2, plagioclásio com alteração fílica: sericitizado (Pgser) e substituído por pirita (Py) e quartzo (Qz) microcristalino. B) Amostra FHD-11, plagioclásio sericitizado (Pgser). C) Amostra FHD-11, máfico substituído por clorita (Cl), sericita (Ser) e carbonato (Ca). D) Quartzo recristalizado nas bordas, com golfos preenchidos por sericita. 


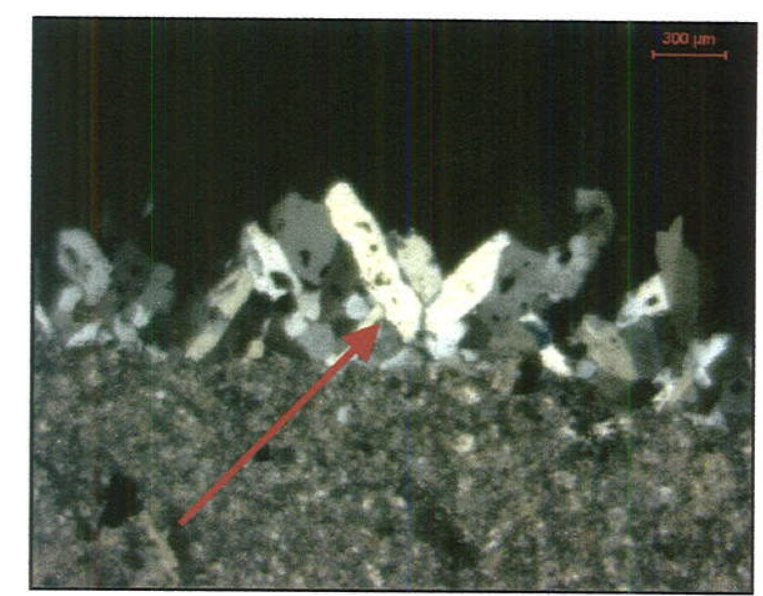

A

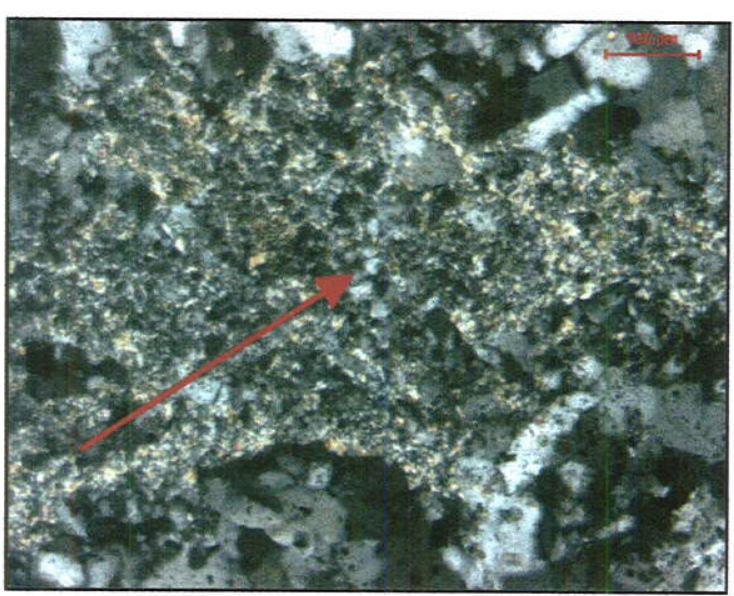

C

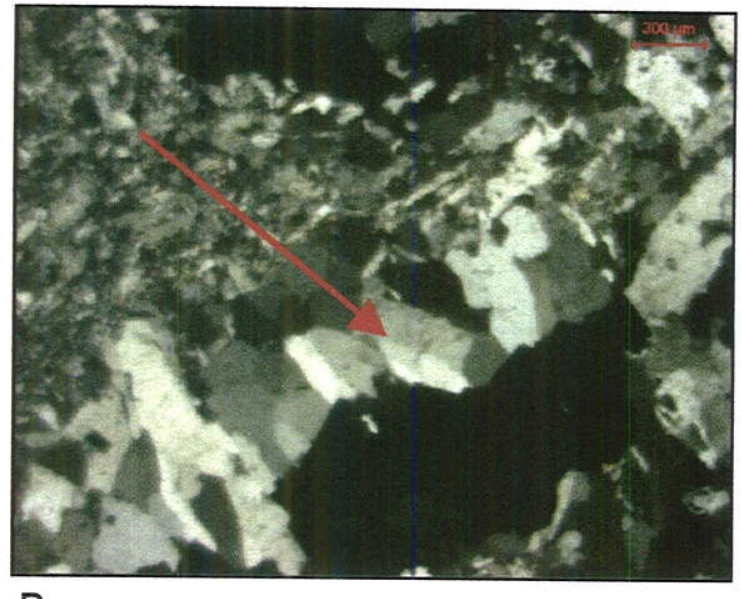

B

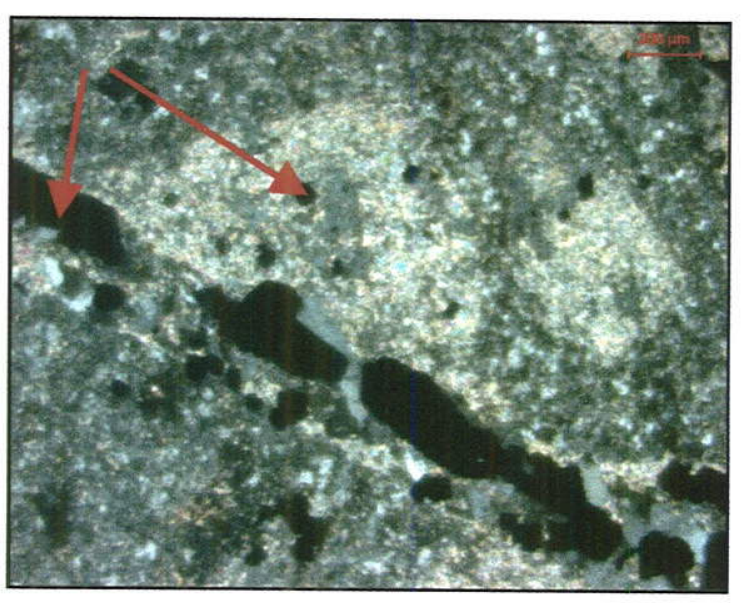

D

Figura 35. Silicificação, imagem no microscópio de luz transmitida, nicóis cruzados. A e B) Quartzo em camadas, A: amostra FHD-2, B: amostra FHD-7. C) Silicificação de matriz, amostra FHD-7. D) Silicificação de matriz e fenocristais, observe o veio de pirita e quartzo cortando 0 cristal, amostra FHD-2 


\subsubsection{INCLUSÕES FLUIDAS}

A informação disponivel sobre inclusões fluidas do Distrito Mineiro de Marmato, está restrita a dois trabalhos, o primeiro realizado por Bedoya (1998) na mina La Maruja e o segundo feito no setor de Echandía por Rossetti et al. (1999). Em termos gerais, pode ser observado um leve incremento na temperatura e na salinidade dos fluidos na mina La Maruja respeito ao setor de Echandía.

\subsubsection{Setor de Echandía}

Rossetti et al. (1999) identifica dois tipos principais de fluidos: o primeiro relacionado com a circulação magmática hidrotermal inicial; o segundo formado por um fluido posterior, menos salino, possivelmente relacionado com um evento formador de sulfetos.

Nos dados microtermométricos de inclusões em fenocristais de quartzo, a homogeneização liquido-vapor ocorreu a uma temperatura entre 270 e $290{ }^{\circ} \mathrm{C}$; a dissolução da silvita e sua homogeneização final a $330-350^{\circ} \mathrm{C}$, a homogeneização da halita entre 450 a $480^{\circ} \mathrm{C}$; a salinidade está entre 53 e $57 \mathrm{wt} \%$ equivalente $\mathrm{NaCl}$.

Nos dados microtermométricos para as inclusões em minerais de veios, a homogeneização do líquido ocorre a temperaturas entre 263 e $312^{\circ} \mathrm{C} \mathrm{com} \mathrm{moda} \mathrm{de} 280$ a $290^{\circ} \mathrm{C}$, a salinidade é de: 1,6-4,7 wt\% $\mathrm{NaCl}$ equivalente. As Inclusões ricas em vapor associadas com as inclusões ricas em liquido, presentes nas zonas de sobrecrescimento do quartzo, mostram homogeneização de vapor a temperaturas entre 270 e $280^{\circ} \mathrm{C}$. Dados de inclusões em esfaleritas pobres em ferro obtiveram temperaturas de homogeneização do liquido entre 293 e $331^{\circ} \mathrm{C}$, com moda entre 300 e $310^{\circ} \mathrm{C}$, com salinidade de 6,2 e 8,1 wt $\mathrm{NaCl}$ eq. 


\subsubsection{Mina La Maruja}

Bedoya (1998), fez um estudo de inclusões fluidas em filões do nível La Maruja, em minerais de quartzo e calcita tanto de estado intermediário como tardio. Foram efetuadas 173 análises em inclusões primarias; as quais foram descritas com tamanhos entre 3 a $21 \mu \mathrm{m}$, simples; com duas fases: liquido e vapor. Obtiveram-se temperaturas de homogeneização entre 250 e $350^{\circ} \mathrm{C}$, com valores médios de $310^{\circ} \mathrm{C}$. 


\section{RESULTADOS ISOTÓPICOS E DISCUSSÕES}

Para a caracterização isotópica das mineralizações auríferas do Distrito Mineiro de Marmato foram realizadas 55 análises isotópicas, sendo 20 pela sistemática $\mathrm{Sr}-\mathrm{Sr}, 9$ em minerais de minério e 11 em rocha total; 18 pela sistemática $\mathrm{Sm}-\mathrm{Nd}, 7$ em minerais de minério e $11 \mathrm{em}$ rocha total (1 deles $\mathrm{Nd} / \mathrm{Nd}$ ); 17 pela sistemática $\mathrm{Pb}-\mathrm{Pb}, 10$ em minerais de minério e 7 em rocha total; e uma datação pelo método $\mathrm{K}$-Ar em plagioclásio alterado hidrotermalmente.

As mineralizações auríferas do Distrito Mineiro do Marmato, como visto no capitulo anterior, consistem de veios distencionais subverticais com orientação NW, e espessura de até $2 \mathrm{~m}$; os quais estão preenchidos de pirita, esfalerita, galena, pirrotita, arsenopirita, calcopirita; mais raramente prata, argentita, "polybasite", oro, electrum (Au$\mathrm{Ag}$ ), teluretos, e sulfossais de $\mathrm{Bi}$; como ganga se têm carbonatos e quartzo. Os veios estão encaixados no Andesito Dacito Pórfiro do Stock de Marmato, o qual intrude rochas metamórficas do Complexo Arquía, rochas ultramáficas, gabros, o Stock de Támesis, rochas sedimentares da Formação Amagá e a parte vulcânosedimentar da Formação Combia de idade Mioceno superior (Restrepo, 1981).

\subsection{VEIOS AURÍFEROS MINERALIZADOS}

Para facilitar a descrição e discussão dos resultados isotópicos, os veios mineralizados foram divididos por setores: setor de Echandía (parte superficial), entre 1600 e 1450 metros de altitude; setor de Cien Pesos (parte intermediaria) entre 1450 e 1300 metros de altitude; setor de Marmato Bajo (parte profunda), entre 1260 e 1110 metros de altitude.

\subsubsection{Setor de Marmato Bajo (parte profunda)}

No setor de Marmato Bajo, foram realizados análises isotópicas em 2 veios mineralizados, em uma brecha hidrotermal e ainda uma datação de rocha encaixante 
alterada hidrotermalmente. O Veio1 é denominado pelos mineiros da região como Mellizos, apresenta orientação NW e nele foram coletadas as amostras FHD-21 no nível 1260 e FHD-25 no nível 1160 metros de altitude; destas amostras foi separada pirita e analisada pelas sistemáticas: $\mathrm{Pb}-\mathrm{Pb}, \mathrm{Sm}-\mathrm{Nd}$ e Sr-Sr. O Veio2, denominado pelos mineiros da região como Ovejo, apresenta orientação NNW e nele foram coletadas as amostras FHD-19 no nivel 1260 e FHD-23 no nível 1210 metros de altitude; da amostra FHD-19 foi separada calcita, posteriormente analisada pela sistemática Sr-Sr, esfalerita analisada pelas sistemáticas $\mathrm{Pb}-\mathrm{Pb}$ e $\mathrm{Sr}$-Sr; e pirita analisada pelas sistemáticas: $\mathrm{Pb}$ $\mathrm{Pb}, \mathrm{Nd}-\mathrm{Nd}$ e $\mathrm{Sr}-\mathrm{Sr}$; da amostra FHD-23 foi separada pirita, sendo analisada para $\mathrm{Pb}-\mathrm{Pb}$, e Sm-Nd. As amostras da brecha hidrotermal (FHD-26 e FHD-27), foram coletadas no nivel 1160 metros de altitude. Esta rocha é composta de carbonatos com fragmentos de dacito pórfiro alterado hidrotermalmente e com sulfetos; da amostra FHD-27 foi separado carbonato para analise Sr-Sr. Da amostra FHD-24 foi separado plagioclásio sericitizado, datado pela sistemática K-Ar; a rocha foi coletada no nível 1160 metros de altitude, e trata-se da encaixante de um veio mineralizado (coletada cerca de $5 \mathrm{~m}$ do veio).

\subsubsection{Resultados das sistemáticas $\mathrm{Sr}-\mathrm{Sr}, \mathrm{Sm}-\mathrm{Nd}$ e $\mathrm{Pb}-\mathrm{Pb}$}

Sistemática Sr-Sr: Os valores das razões isotópicas ${ }^{87} \mathrm{Sr} /{ }^{86} \mathrm{Sr}$ obtidos nas amostras do setor de Marmato Bajo, estiveram entre 0,70444 e 0,70930. Os valores mais baixos estão relacionados à calcita da brecha hidrotermal da amostra FHD-27 e o valor mais elevado à pirita da mostra FHD-25 do Veio1. As piritas apresentaram as maiores variações isotópicas e foram as mais radiogênicas, com razões ${ }^{87} \mathrm{Sr} /{ }^{86} \mathrm{Sr}$ entre 0,70500 e 0,70930; já a razão ${ }^{87} \mathrm{Sr} /{ }^{86} \mathrm{Sr}$ da esfalerita da amostra FHD-19 e seus lixiviados ( $L 1$ e $L 2$ ), apresentaram valores menos radiogênicos e mais homogêneos, entre 0,70500 e 0.70590 ; os valores isotópicos das calcitas foram muito similares e menos radiogênicos, variando entre 0,70444 e 0,70450. Nos veios mineralizados, o Veio1 foi mais radiogênico do que o Veio2; a razão ${ }^{87} \mathrm{Sr} /{ }^{86} \mathrm{Sr}$ varia entre 0,70500 e 0,70930 no Veio1; e entre 0,70451 e 0,70670 no Veio2 (Tabela 6, Figura 36). 
TABELA 6. RESULTADOS DA RAZĀO ${ }^{87} \mathrm{Sr} r^{86} \mathrm{Sr}$, PARA TODAS AS AMOSTRAS

\begin{tabular}{|c|c|c|c|c|c|c|c|c|c|c|c|c|c|}
\hline $\begin{array}{l}\text { Localizaçào } \\
\text { Parte superficial(Sector de Echandia) }\end{array}$ & $\begin{array}{l}\text { No de } \\
\text { Campo } \\
\text { FHD-1 }\end{array}$ & Rocha & Material & $\begin{array}{l}\text { No de lab: } \\
\text { SPRR } \\
1452\end{array}$ & Sir(ppm) & EST: & Rblppm) & ERB & RoISr & ${ }^{87} \mathrm{Rb} / 8 \mathrm{ST}$ & Enro & $\left(\mathrm{Hioje}^{80} \mathrm{sr}\right.$ & Erro \\
\hline \multirow[t]{3}{*}{ Parte intermediaria(Sector de Cien Pesos) } & FHD-14 & Veio com mineralização & Pinita & 14662 & j-2,3 & $-20,2$ & 4.9 & & & & & 0.704721 & 0,000085 \\
\hline & FHD-16 & Veio com minerafizaçāo & Pirita & 14613 & -3 & -88.7 & $\frac{1.6}{6.6}$ & $\frac{34,0}{120}$ & $\frac{1-6,75}{1-6,47}$ & & & 0.712100 & 0,003000 \\
\hline & FHD-16 & Veio com mineralizaçăo & Calcita & 14555 & 306,6 & 11,1 & 4.5 & 31,4 & 0,04 & & & 0,707160 & 0,000330 \\
\hline Veio 1, Parte profunda (Setor de Marmato Bajo) & \begin{tabular}{|l} 
FHD-21 \\
FHD-25
\end{tabular} & Veio com mineralizaçáno & Pirita & 14615 & & & & & & & & $\frac{0,704660}{10,705030}$ & $\frac{0,000035}{10,000700}$ \\
\hline \multirow{4}{*}{$\begin{array}{l}\text { Veio2 } \\
\text { Parte profunda(Sector de Marmato Bajo) }\end{array}$} & FHD-19 & $\begin{array}{l}\text { Veio com mineralizz̧ă̄o } \\
\text { Veio com mineralizz̧çăó }\end{array}$ & Pirita & $\frac{14617}{14614}$ & -4 & & & & & & & 0.709370 & 0,000300 \\
\hline & & & Esfalerita & $14553 \mathrm{RT}$ & $t^{-4}$ & 10,6 & $16, ?$ & 47,5 & $-12,08$ & {$[1,166$} & & $\frac{0.706790}{0,705020}$ & $\frac{0,000500}{0,001000}$ \\
\hline & & & $\begin{array}{l}\text { Esfalerita } L 1 \\
\text { Esfalerita } L 2\end{array}$ & $\frac{1455311}{1455312}$ & & & & & & 0,0338 & 0,0003 & 0.705150 & 0,000110 \\
\hline & & & Calcita & $\frac{1743562}{14554}$ & & 115 & 48 & & & 0,468 & 0,0036 & 10.705920 & 00230 \\
\hline Parte profunda(Seclor de Marmato Bajo) & FHD-27 & Brecha hidroternal & Calcita & 14556 & 103.1 & 0,6 & 11,2 & $\frac{1.2}{1.3}$ & $\frac{0.36}{0.31}$ & & & 0.704512 & 0,000049 \\
\hline Corrego Chirapoto & CJ-01 & Pórfiro Látitico & $R T$ & 2348 & 1172.1 & 0,7 & 39 & 1.5 & 0,1 & & & 0,704442 & 0,000451 \\
\hline Corrego Chirapoto & $\omega-66 \mathrm{~A}$ & Dacito Pórfiro & RT & 2353 & 1064.4 & 0,1 & 50,2 & 1,3 & 0.14 & & & 0,704447 & 0,000056 \\
\hline Marmato & $16 M-6921$ & Microdiorita Porfirítica & $\mathrm{RT}$ & 2383 & 964 & 0 & 54,6 & 1,7 & 0.16 & & & $\frac{0,704599}{0.70447}$ & 0,000085 \\
\hline NW de Caramanta & $16 M-8763$ & Diorito com horblenda & $\mathrm{RT}$ & 2385 & 906.4 & 0.6 & 7.3 & 3.8 & 0,02 & & & 10,704477 & $\frac{0,000049}{0,000056}$ \\
\hline Marmato & FHAD- & Xisto grafitoso & $R T$ & 2354 & & & & & & & & $\frac{10.003816}{0.735108}$ & \begin{tabular}{|l|l}
0.000125 \\
0.000
\end{tabular} \\
\hline Conego Chirapoto & $C J-03$ & Xisto Quartzo Biotitico & $R T$ & 2350 & 247.2 & 0.1 & 186,7 & 0,6 & 2,19 & & & 0.714914 & 0,000093 \\
\hline Corrego Chirapoto & CS -04 & Xisto Anfibolítico & $\mathrm{RT}$ & 2351 & 1109.5 & 0.8 & 31 & 11.8 & 0,82 & & & 10,704306 & 10,000056 \\
\hline Corrego Chirapoto & CaN-06 & Xisto Anfibolitico & $R T$ & 2352 & 1133,5 & 1,7 & 72,1 & 1,7 & 1.56 & & & 0.706200 & 0.000078 \\
\hline S de Jardin & $1 G M-119089$ & Basalto & RT & 2384 & 502 & 0.2 & 37.9 & 3,2 & 0,22 & & & 0.703957 & 0,000063 \\
\hline $\begin{array}{l}\text { Rodovia Troncal de Ocidente } \\
\text { Corrego Chirapoto }\end{array}$ & IGM-6912 & Dunito Serpentinizado & $\frac{R T}{R T}$ & 14696 & 1,6 & 1114,9 & 0.7 & 76.1 & 1.18 & & & 0.704750 & 0,000282 \\
\hline Corrego Chirapoto & CJ-02 & Piroxenito & RT & 2349 & 8,2 & 1,7 & 2.1 & 3.4 & 10.72 & & & 10,706841 & 10.000057 \\
\hline
\end{tabular}

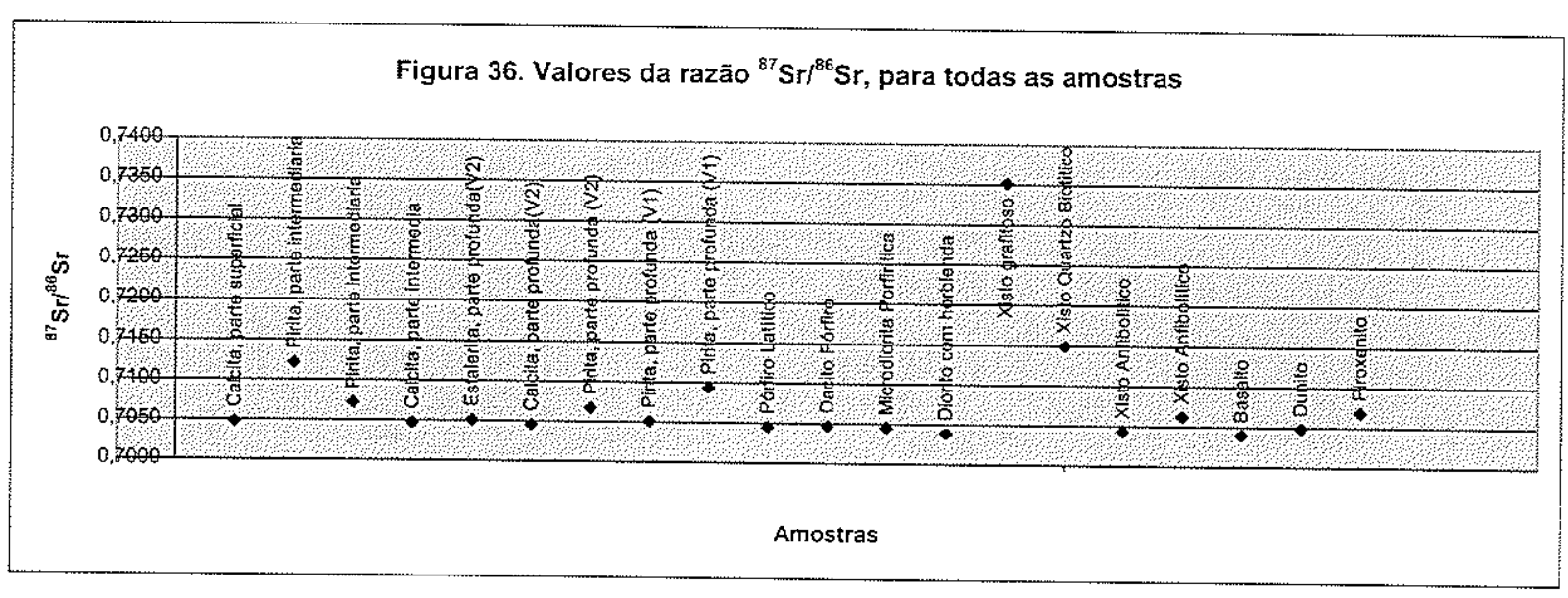


Sistemática $\mathrm{Sm}-\mathrm{Nd}$ :Os resultados isotópicos obtidos pela sistemática $\mathrm{Sm}-\mathrm{Nd}$ apresentaram um comportamento homogêneo. $O$ valor mínimo do $\varepsilon_{\mathrm{Nd}(0)}$ foi de $+1,95$ nas piritas da amostra FHD-25 (Veio1), e o valor máximo de $\varepsilon_{\mathrm{Nd}(0)}$ foi de $+3,28$ nas piritas da amostra FHD-19 (Veio2). O Veio2 apresentou os maiores valores de $\varepsilon_{\mathrm{Nd}(0)}$, entre $+2,79$ e +3,28; já no Veio1, o valor de $\varepsilon_{\text {Nd(0) }}$ variou entre $+1,95$ e $+2,85$ (Tabela 7, Figura 37 ).

Sistemática Pb-Pb: Os resultados isotópicos das amostras analisadas pela sistemática $\mathrm{Pb}-\mathrm{Pb}$, apresentaram valores mais radiogênicos nas piritas do que na esfalerita, e mais radiogênicos no Veio2 do que no Veio1.

Os valores isotópicos das razões ${ }^{206} \mathrm{~Pb} /{ }^{204} \mathrm{~Pb},{ }^{207} \mathrm{~Pb} /{ }^{204} \mathrm{~Pb}$ e ${ }^{208} \mathrm{~Pb} /{ }^{204} \mathrm{~Pb}$, variaram respectivamente entre: 18,970 e 19,065 (piritas das amostra FHD-25 e FHD-19); 15,613 e 15,699 (piritas das amostra FHD-25 e FHD-19); 38,827 e 39,115 (piritas das amostras FHD-21 e FHD19).

Nas piritas do Veio2, obtiveram-se os valores mais radiogênicos, as razões ${ }^{206} \mathrm{~Pb} /{ }^{204} \mathrm{~Pb},{ }^{207} \mathrm{~Pb} /{ }^{204} \mathrm{~Pb}$ e ${ }^{208} \mathrm{~Pb} /{ }^{204} \mathrm{~Pb}$ variaram respectivamente entre: 19,042 e 19,065 (FHD-23 e FHD-19); 15,680 e 15,699 (FHD-23 e FHD-19); 39,041 e 39,115 (FHD-23 e FHD-19). A esfalerita da amostra FHD-19, apresentou valores menos radiogênicos em relação às piritas do mesmo veio, suas razões ${ }^{206} \mathrm{~Pb} /{ }^{204} \mathrm{~Pb},{ }^{207} \mathrm{~Pb} /{ }^{204} \mathrm{~Pb}$ e ${ }^{206} \mathrm{~Pb} /{ }^{204} \mathrm{~Pb}$ foram: 19,010, 15,619 e 38,842, respectivamente.

As piritas do Veio1 apresentaram valores menos radiogênicos, com as razões ${ }^{206} \mathrm{~Pb} /{ }^{204} \mathrm{~Pb},{ }^{207} \mathrm{~Pb} /{ }^{204} \mathrm{~Pb},{ }^{208} \mathrm{~Pb} /{ }^{204} \mathrm{~Pb}$ variando entre: 18,970 e 18,999 (FHD-25 e FHD21), 15,613 e 15,615 (FHD-25 e FHD-21), 38,827 e 38,862 (FHD-21 e FHD-25), respectivamente (Tabela 8 , Figuras $38,39,40$ ).

\subsubsection{Determinação da idade da mineralização}

Na determinação da idade da mineralização foram utilizadas duas técnicas, a primeira pelo Método K-Ar em plagioclásio sericitizado, procurando obter a idade da alteração hidrotermal sericítica, relacionada à mineralização. 
TABELA 7. VALORES DE $\varepsilon_{\mathrm{N} \sigma\{0\}}$, PARA TODAS AS AMOSTRAS

\begin{tabular}{|c|c|c|c|c|c|c|c|c|c|c|c|c|c|c|}
\hline lochiliario & No de Campor & Rochir & Matorial & $\begin{array}{c}\text { No do Lobortoro } \\
\text { (sps) }\end{array}$ & sm & No & Tsmir ${ }^{\text {No }}$ & Erro & 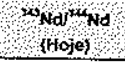 & Ero & tsmim & Tonar: & Erro & $\varepsilon_{\text {NalHolel }}$ \\
\hline & FHO-2 & $\begin{array}{l}\text { Veio com suffetos e ateractzo } \\
\text { veio com mineralizacroo }\end{array}$ & \begin{tabular}{|l} 
Pirtite \\
Pirta
\end{tabular} & 2264 & 0.047 & 0.233 & 0.1241 & 0,0005 & 0.512581 & 0,000028 & -0.37 & 795.9 & 43,9 & -1.11 \\
\hline Parte intermedia(Sector de Cien Pesos) & $\begin{array}{l}\text { FHD-14 } \\
\text { FHD-16 }\end{array}$ & $\begin{array}{l}\text { Veio com mineralizaço } \\
\text { Veio com mineralizarso }\end{array}$ & $\frac{\text { Pinta }}{\text { Pirita }}$ & 2265 & 0,056 & 0.258 & 0.1316 & 0.0005 & 0.512512 & 0,000038 & -0.33 & 991.2 & 64.5 & $-2,45$ \\
\hline Parte p:ofunda/Sector de Marmato Bajo) & $\frac{\mid F F D-16}{F F D-27}$ & $\begin{array}{l}\text { Velio com minerakizarso } \\
\text { Veio com mineralizeçăso }\end{array}$ & Pinta & 2266 & 0.033 & $\frac{0.151:}{3.059: 0}$ & $0.0,3315$ & 0.0004 & 0.512764 & 0.000017 & -0.33 & 540.5 & 28,9 & 2.46 \\
\hline Veio 1 & $=H O-25$ & Veip com minteralizaszo. bxidos & Pirita & 2270 & 0.025 & 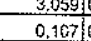 & 0.1292 & 0.0004 & $\frac{0,512784}{0.512738}$ & 0.000014 & -0.23 & 491.8 & 23,2 & 2,85 \\
\hline Parte profunda(Sector de Marmato zaio) & FHD-19 & Veio com mineralizaşa & Pinte. & 2267 & 0.12 & 0.496 & 0.1483 & 0.0005 & $\frac{0.512738}{0.512806}$ & 0.000017 & $-\frac{-0.29}{-0.06}$ & 648.5 & 31,9 & 1.95 \\
\hline Vein? & FHD-23 & Veio com mineralizas a & Pinta & 2269 & 0.018 & 0.076 & 0.1402 & 0.0005 & $\begin{array}{l}0,512806 \\
0,51781\end{array}$ & 0.000089 & -0.25 & 578.5 & 184.8. & 3.28 \\
\hline Corrego Chirapoto & c. 101 & Pórifro Latitico & |RT & 2348 & 2.961 & 14,345 & 0.1228 & 1000004 & $\frac{0.512781}{0.51302}$ & 0.000014 & -0.29 & 567.3 & 26,4 & 2.79 \\
\hline Corrego Chirapoto & $C J-66 A$ & Dacito Pórfiro & RT & 2353 & 2,976 & 14948 & & & 0.512802 & 0.000016 & -0.37 & 439.5 & 25.3 & 3,20 \\
\hline Mamato & IGM-6921 & Microdiorita Porfidics & RT & 2383 & & & & 10.0004 & 0.51279 & 0.000009 & -0.39 & 438,3 & 13.7 & 2.97 \\
\hline NW de Caraman!a & $16 \mathrm{M}-8763$ & foionito com. Horblenda & RT & 2385 & 28.353 & $\frac{17.767}{111096}$ & $\frac{0,1207}{0.157}$ & $\frac{10.0004}{10006}-x-3$ & 0.512752 & 0,000011 & -0.39 & 499.0 & 16.8 & 2.22 \\
\hline Marmato & FHO-6 & Xisto Grafiroso & RT & 2354 & 2.08352 & $\frac{111,04}{9.294 !}$ & $\begin{array}{l}0.1571 \\
0.1354\end{array}$ & $\frac{0.0006}{10.0005}$ & -0.512833 & 0.000011 & -0.20 & 594.4 & 26.6 & 3.80 \\
\hline Corrego Chirapoto & $C,-03$ & Xisto quartzo biotitico & RT & 2350 & 11.219 & 57.2289!! & $\begin{array}{l}0.1354 \\
0.1184\end{array}$ & 0 & $\begin{array}{l}0.512061 \\
0.511976\end{array}$ & 0,000021 & -0.31 & 1910.4 & 38,8 & $-11,26$ \\
\hline Corrego Chirapoto & a -04 & Xisto anfífolitico & RT & 2351 & 2.957 & 7.961 & 0.2246 & 0,0008 & $\begin{array}{l}0.511976 \\
0.5131182\end{array}$ & 0.000009 & -0.40 & 1704.6 & 14.7 & $-12,99$ \\
\hline Corrego Chirapoto & $\omega-06$ & Xisto anfibolitico & $\mathrm{RT}$ & 2352 & 5.068 & 19.42 & 0.1580 & $\frac{10.0600}{100005}$ & 0.513182 & 0.000014 & 0.14 & & & 10.61 \\
\hline S Jardin & $16 M-199089$ & Bassato & RT & 2384 & 2948 & 97940 & $\frac{0.1520}{0.820}$ & & 0.512654 & 0,000012 & -0.20 & 1066.5 & 30,1 & 0.31 \\
\hline Corrego Chirapoto & $\omega_{-102}$ & Piroxenito & RT & 2349 & 0.056 & 0.145 & 0.2348 & $\frac{10.0006}{10.0008}$ & $\frac{0.512878}{0.513167}$ & 0.000011 & 0.07 & 817.5 & 44.2 & 4.68 \\
\hline TToncal de Occiciente & $16 M-6912$ & Dunito serpentinizaco & RT & 2336 & & & & & $\frac{0.513167}{0.512866}$ & $\frac{0.000024}{0.000018}$ & 0.19 & & & $\frac{10,32}{445}$ \\
\hline
\end{tabular}

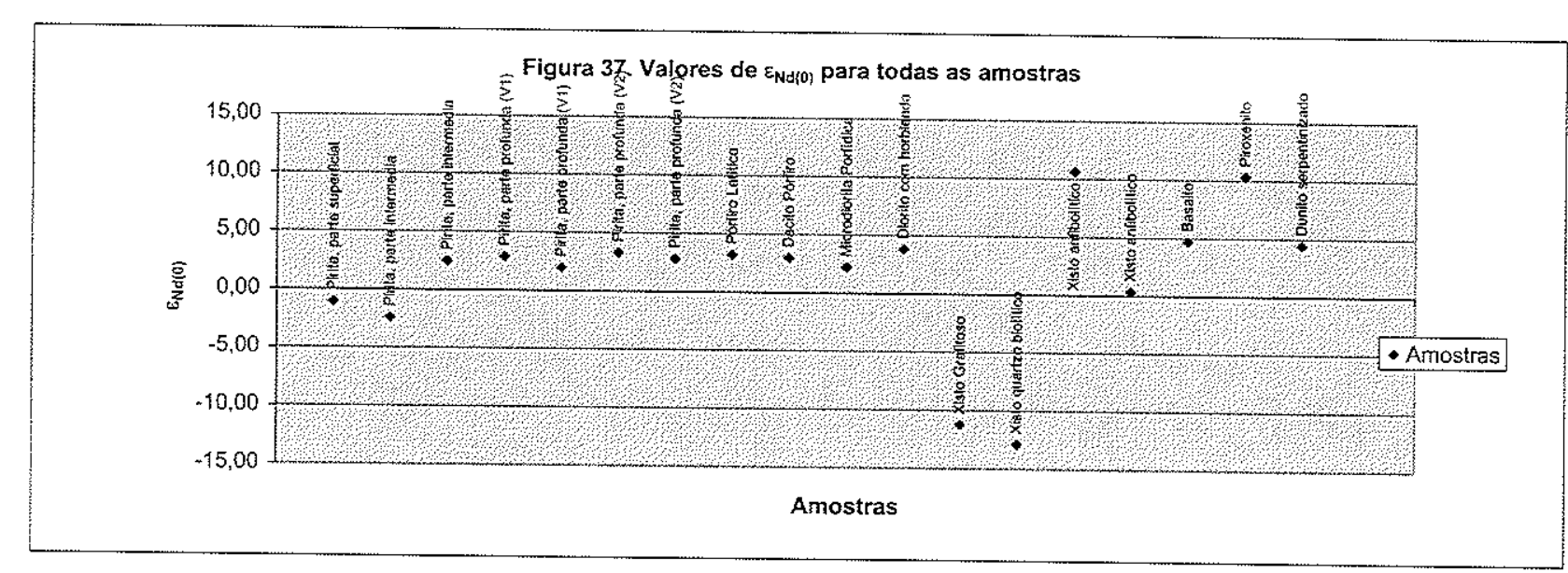


TABELA 8. RESULTADOS DAS RAZÕES ISOTÓPICAS Pb/Pb PARA TODAS AS AMOSTRAS

\begin{tabular}{|c|c|c|c|c|c|c|c|c|c|c|}
\hline Localizacá & No de Campo & Rocha & Material & $\begin{array}{l}\text { No de laboratorio } \\
\text { SPB }\end{array}$ & $2026 f^{204} \mathrm{~Pb}$ & $\begin{array}{l}\text { Erro } \\
\text { (2) }\end{array}$ & $\mathrm{Pb}^{204} \mathrm{~Pb}$ & Eiro & ${ }^{206 \mathrm{~Pb}^{25} \mathrm{~Pb}}$ & Erro \\
\hline \multirow[t]{2}{*}{ Parte superficial (Sector de Echandia) } & FHD-2 & Veio com sulfetos e alterą̧āo & Pirita & 762 & 19.058 & 0.101 & 15,706 & 0,125 & 39,209 & $0,14 i$ \\
\hline & & & \begin{tabular}{|l} 
Esfalerita \\
Galena
\end{tabular} & $\begin{array}{l}761 \\
759 \\
\end{array}$ & $-\frac{19,100}{1003}$ & 0.076 & 15.715 & 0,071 & 39,170 & 0,083 \\
\hline \multirow[t]{2}{*}{ Parte internedia (Sector de Cien Pesos) } & FHD-14 & Veio com mineralizaçăo & Pirita & 763 & $\frac{19,003}{19,067}$ & $\frac{0,026}{0,046}$ & $\frac{15,605}{1576}$ & $\frac{0.023}{0.17}$ & 38,813 & $\frac{0,023}{0.048}$ \\
\hline & FHD-16 & & Pirita & 764 & 19,258 & $0.0,176$ & $\frac{15,726}{15,910}$ & $-0,047$ & $\begin{array}{l}39,208 \\
39,751\end{array}$ & 0.0483 \\
\hline \multirow{2}{*}{ Parte profunda(Sector de Marmato bajo), Veio 1} & $\mid \begin{array}{ll}\text { FHD-21 } \\
\text { FHD } 25\end{array}$ & Veio com mineralizaçäo & Pinita & 766 & 18.999 & 0.020 & 15.615 & 0,020 & 38,827 & 0.023 \\
\hline & $\frac{1 F H D-25}{F+19}$ & Veio com mineralização e óxidos & Pirita & 768 & 18.970 & 0,057 & 15,613 & 0,059 & 38.862 & 0,060 \\
\hline \multirow{2}{*}{ Parte profunda(Sector de Marmato bajo), Veio 2} & FHD-19 & Veio com mineralizaçăo & Pirita & $\frac{765}{760}$ & $\begin{array}{l}19,065 \\
19,010 \\
\end{array}$ & 0,049 & $\begin{array}{ll}15,699 \\
15,199 \\
\end{array}$ & 0.048 & 39,115 & 0.049 \\
\hline & FHD-23 & Veio com mineralização & Pirita & 767 & 19.047 & 0,035 & $\frac{15,619}{15,600}$ & 0.036 & 38,842 & 0,037 \\
\hline Corrego Chirapoto & $\mathrm{CJ}_{-01}$ & Latitico Pórfiro & RT & 782 & 18,964 & 0,051 & $\frac{15,680}{15,564}$ & $\frac{0,051}{0,018}$ & 39,041 & 0,052 \\
\hline Corrego Chirapoto & CJ.66A & Dacito Pórfiro & RT & 787 & 18,971 & 0,027 & $\mid \frac{15,564}{15.570}$ & $\begin{array}{ll}0,018 \\
0,028 \\
\end{array}$ & $\begin{array}{ll}38,640 \\
38,673 \\
\end{array}$ & $\frac{0.019}{0.028}$ \\
\hline Marmato & IGM-6921 & Microdiorita Porfidica & RT & 859 & 18.982 & 0,008 & 15,569 & 0.008 & $\frac{38,673}{38,588}$ & $\frac{0.028}{0.008}$ \\
\hline NW de Caramanta & $1 G M-8763$ & Diorito com horblenda & RT & 860 & 19,028 & 0,031 & 15,561 & 0,032 & 38,745 & 0.033 \\
\hline \begin{tabular}{|l|} 
Marmato \\
Cormeonizan
\end{tabular} & FHD-6 & Xisto Grafitoso & RT & 788 & 18,948 & 0.026 & 15,617 & 0,029 & 38.885 & 0,030 \\
\hline Corrego Chirapoto & CJ-03 & Xisto Quartzo Biotitico & $R T$ & 784] & 19.652 & 0,057 & 15,702 & 0,056 & 39.118 & 0,062 \\
\hline Corrego Chirapoto & CJ-06 & Xisto Anfibolitico & IRT & $786 \mid$ & 19,131 & 0,026 & 15.609 & 0,026 & 38,807 & 0,027 \\
\hline
\end{tabular}
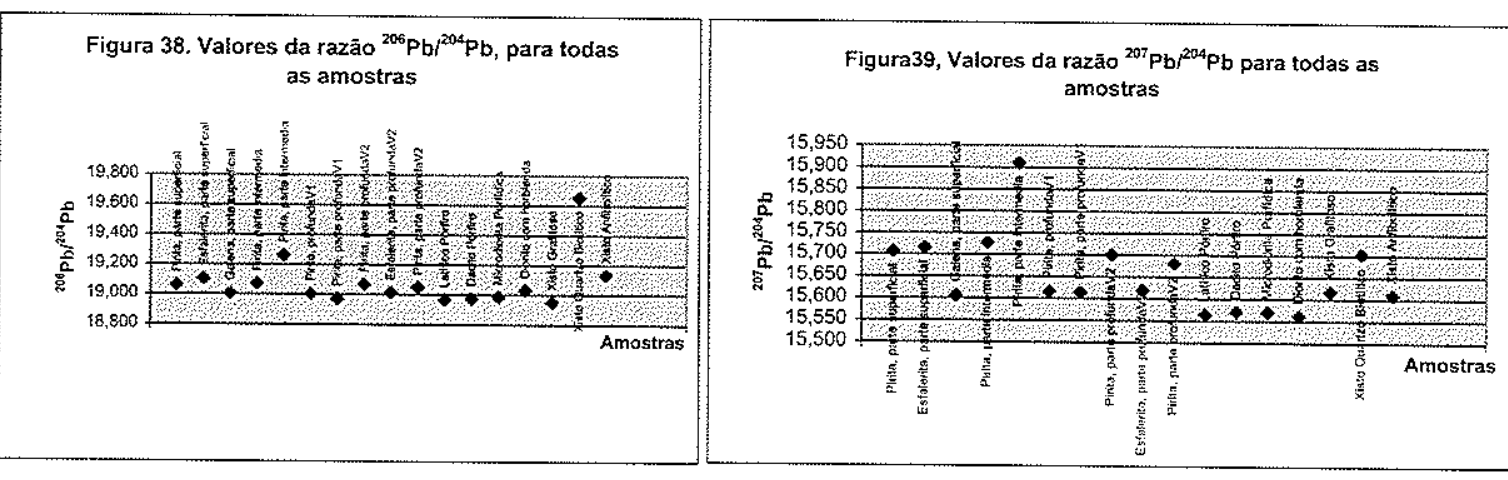

Figura 40. Valores da razão ${ }^{208} \mathrm{~Pb}{ }^{204} \mathrm{~Pb}$, para todas as amostras

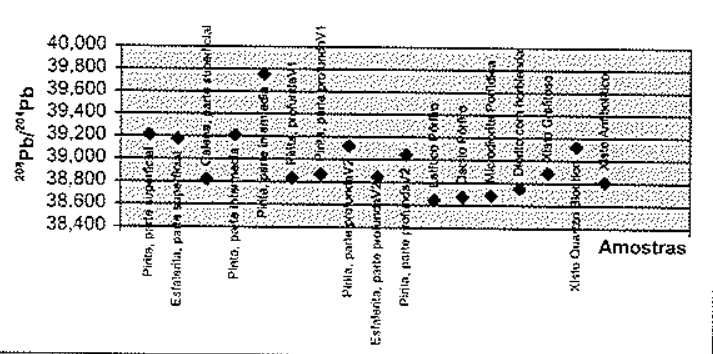


A segunda pelo Método Rb-Sr em produtos de lixiviados da esfalerita, procurando obter a idade diretamente da mineralização.

\section{a. Método K-Ar}

O Andesito Dacito Pórfiro de Marmato, como visto no capítulo da Geologia local, encontra-se afetado na zona das mineralizações, por ampla alteração hidrotermal propilítica e por restrita sericitização nas paredes dos veios. A propilitização caracte rizase pela substituição dos minerais máficos e do plagioclásio por clorita, epidoto, calcita e em menor proporção sericita; a sericitização caracteriza-se pela substituição do plagioclásio por sericita e pirita. A amostra FHD-24 é descrita em termos gerais, como uma rocha subvulcânica de tipo dacítico com textura Porfirítica afetada por forte alteração hidrotermal propilitica e fílica, localmente apresenta sulfetos disseminados; os fenocristais de plagioclásio são de tamanho médio de 3 a $5 \mathrm{~mm}$, e estão completamente alterados e substituídos por sericita, epidoto e calcita; alguns plagioclásios apresentam sericitização parcial (Figuras 41, 42).

Os fluidos hidrotermais circulantes que deram origem às alterações hidrotermais no depósito de Marmato, tiveram temperaturas superiores a $250{ }^{\circ} \mathrm{C}$, de acordo com as análises microtermométricas efetuadas por Bedoya (1998) no nivel Maruja e por Rossetti et al. (1999) no setor de Echandía; que provavelmente abriram o sistema K-Ar dos plagioclásios, e que por tanto a analise $\mathrm{K}$-Ar nestes minerais poderia fornecer a idade deste processo de alteração hidrotermal e consequentemente da mineralização.

Neste sentido foi efetuada uma datação $\mathrm{K}$-Ar em plagioclásio sericitizado da amostra (FHD-24), cujos dados analíticos constam da Tabela 6 . O teor de $K$ obtido $(1,76 \%)$ é mais alto do que aquele esperado para plagioclásio, mostrando que o mineral datado já estava afetado pelo processo de alteração hidrotermal.

Tabela 9. Dados analíticos da amostra FHD-24, sistemática K-Ar

\begin{tabular}{|c|c|c|c|c|c|c|c|c|c|}
\hline SPK & $\begin{array}{c}\text { No de } \\
\text { campo }\end{array}$ & Rocha & $\begin{array}{c}\text { Material } \\
\text { analisado }\end{array}$ & $\%$ de K & $\begin{array}{c}\text { Erro de } \\
\mathrm{K}(\%)\end{array}$ & $\begin{array}{l}{ }^{60} \mathrm{Ar} \text { Rad } \\
\text { ccSTP/g (106) }\end{array}$ & $\begin{array}{c}{ }^{30} \text { Ar Atm } \\
(\%)\end{array}$ & $\begin{array}{c}\text { Idade } \\
(\mathrm{Ma})\end{array}$ & $\begin{array}{c}\text { Erro Max } \\
(\mathrm{Ma})\end{array}$ \\
\hline 7810 & FHD-24 & $\begin{array}{l}\text { Dacito } \\
\text { Porfirítico }\end{array}$ & $\begin{array}{l}\text { Plagioclásio, } \\
\text { alterado }\end{array}$ & 1,7661 & 0,6266 & 0,38 & 65,30 & 5,6 & 0,6 \\
\hline
\end{tabular}




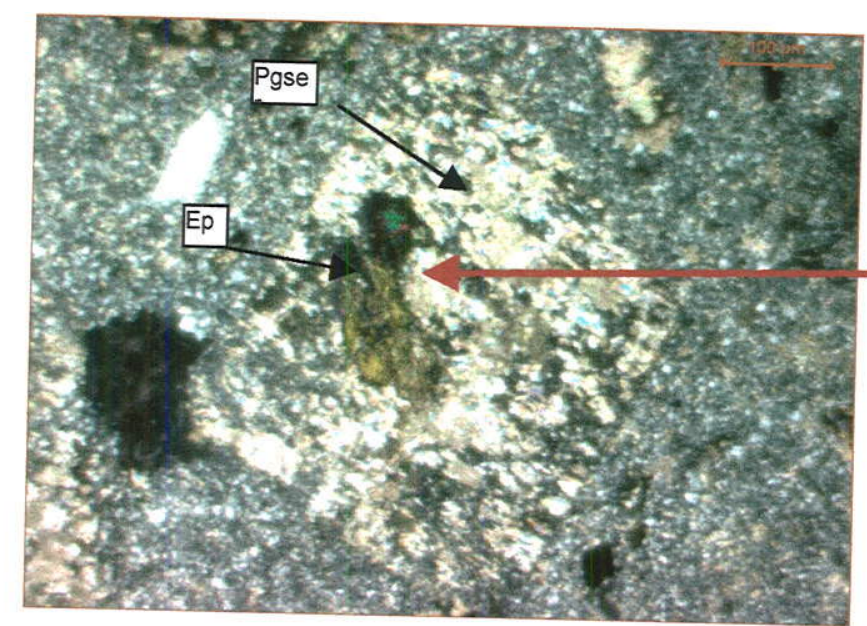

A

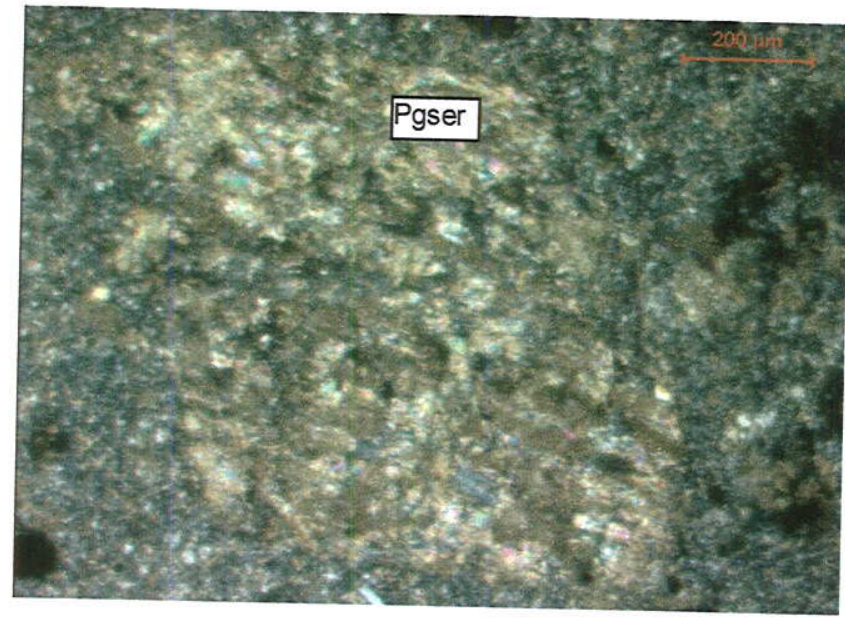

C

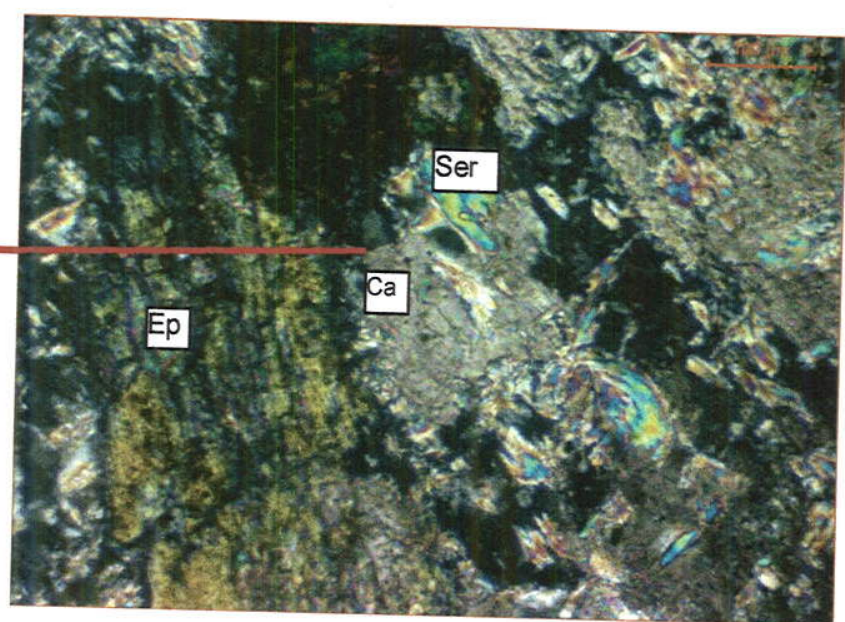

B

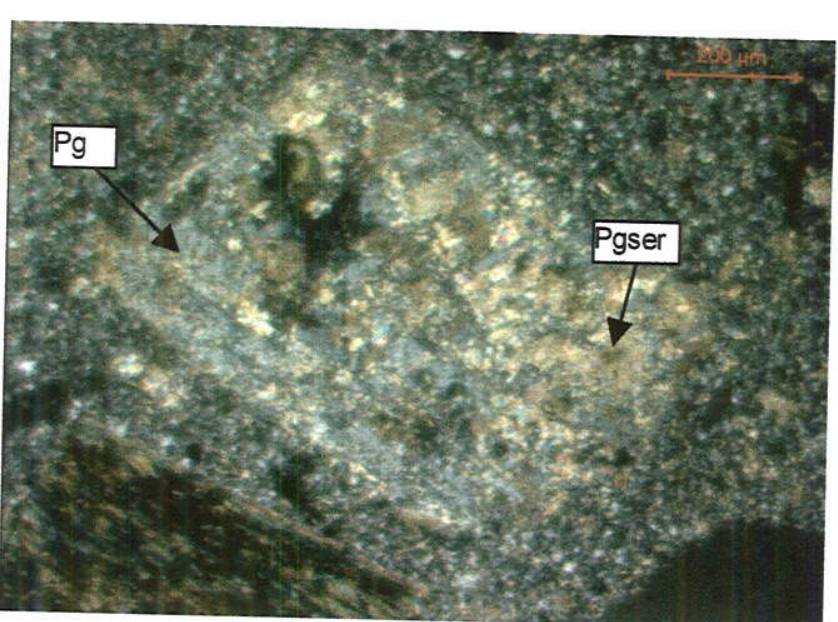

D

Figura 41. Plagioclásio sericitizado da amostra FHD-24. A, B e C: Plagioclásio sericitizado (Pgser), substituído por sericita(Ser), epidoto(Ep) e calcita(Ca). D: Plagioclásio parcialmente
sericitizado. 


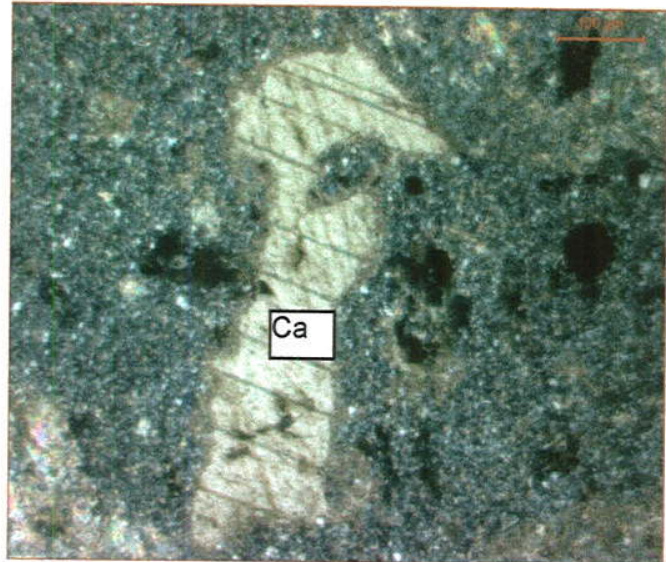

A

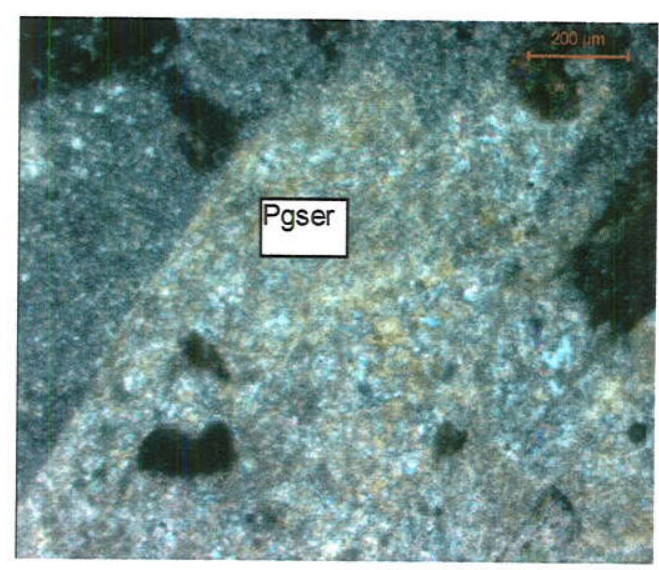

C

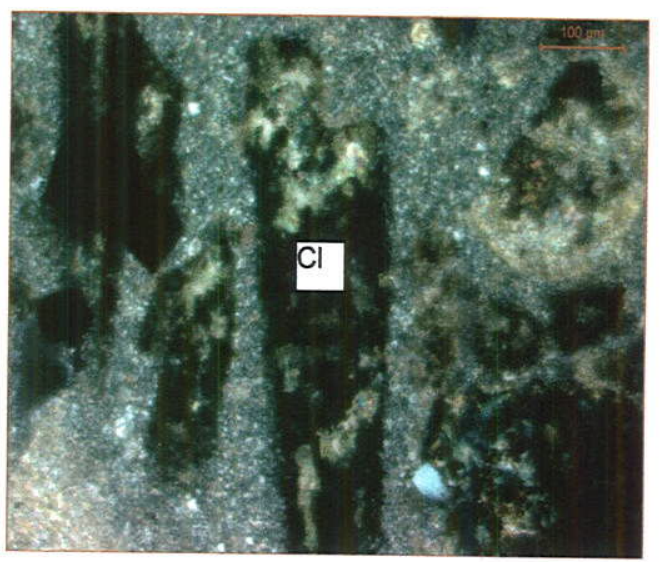

B

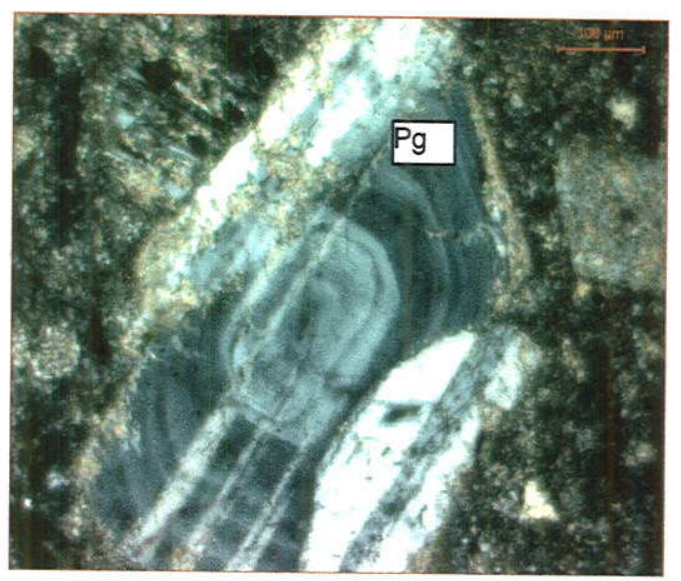

D

Figura 42. A) Calcita(Ca) recristalizada em matriz da amostra FHD-24. B) Cloritização(Cl) de máficos, amostra FHD-24. C) Plagioclásio sericitizado. D) Amostra FHD-5, plagioclásio levemente sericitizado nas bordas e fraturas, observe a diferença com o plagioclásio sericitizado da amostra FHD-24(c). 
A idade obtida foi de $5,6 \pm 0,6 \mathrm{Ma}$, a que é interpretada como a idade do evento de alteração hidrotermal sericítica que afetou os dacito pórfiros. Como a alteração hidrotermal está restrita às paredes dos veios, e associada com sulfetos; é possível sugerir que foi originada pela interação das rochas encaixantes com os fluidos hidrotermais; podendo admitir a idade K-Ar como próxima da época da mineralização.

\section{b. Lixiviação em esfalerita}

Visando obter a idade da mineralização diretamente nos minerais de minério, foram realizadas análises isotópicas $\mathrm{Rb}-\mathrm{Sr}$ em produtos de lixiviados de esfalerita da amostra FHD-19 (Veio2), que foi coletada no nível 1260 do setor de Marmato Bajo. Na tabela 7 encontram-se listados os resultados analíticos.

Tabela 10. Resultados Isotópicos dos produtos lixiviados, do resíduo e da dissolução total da esfalerita da amostra FHD-19

\begin{tabular}{|l|l|l|l|l|l|l|}
\hline Lixiviação & \multicolumn{1}{|c|}{$\begin{array}{c}\mathbf{R b} \\
(\mathbf{p p m})\end{array}$} & $\begin{array}{c}\mathrm{Sr} \\
(\mathrm{ppm})\end{array}$ & ${ }^{87} \mathbf{R b} /{ }^{86} \mathrm{Sr}$ & Erro & ${ }^{87} \mathbf{S r} /^{86} \mathbf{S r}$ & Erro \\
\hline DT $^{*}$ & 0,26 & 0,64 & 1,1660 & 0,0100 & 0,70502 & 0,00100 \\
\hline $\mathrm{L}^{*}$ & 0,66 & 56,91 & 0,0338 & 0,0003 & 0,70515 & 0,00011 \\
\hline $\mathrm{L} 2$ & 0,37 & 2,31 & 0,4680 & 0,0036 & 0,70592 & 0,00023 \\
\hline
\end{tabular}

DT: Dissolução Total, L: lixiviado.

Os resultados isotópicos dos lixiviados e do resíduo foram lançados num diagrama isocrônico, e os pontos analiticos apresentaram grande dispersão, não permitindo a obtenção de isócrona. Entre tanto as composições isotópicas obtidas (DT, L1 e L2) foram utilizadas com fins de geoquimica isotópica. Os dados do L3, L4 e o resíduo foram descartados pelos baixos conteúdos do $\operatorname{Sr}(0,02$ até $0,09 \mathrm{ppm})$, e pelos 
altos erros. No estudo realizado no Microscópio Eletrônico de Varredura (MEV), nesta esfalerita foram observados argilominerais numa fratura, assim como microcristais de carbonato; o qual sugerem a presença de minerais não homogeneizados isotópicamente com a esfalerita, e que por tanto poderiam produzir a dispersão observada (Figura 43, 44).

\subsubsection{Setor de Cien Pesos (parte intermediaria)}

Na mina Villonza, situada a 1300 metros de altitude, foi coletada a amostra FHD16; os veios da mina Villonza apresentam uma orientação NWW (Medina, 1989) (esse veio pode corresponder ao Veio2 do setor de Marmato Bajo), desta amostra foram separadas calcita para analises $\mathrm{Sr}-\mathrm{Sr}$ e pirita para analises $\mathrm{Sr}-\mathrm{Sr}, \mathrm{Sm}-\mathrm{Nd}$ e $\mathrm{Pb}-\mathrm{Pb}$. $\mathrm{Na}$ mina La Mona, situada a 1300 metros de altitude, foi coletada a amostra FHD-14, nos veios orientados E-W até NWW (Restrepo, 1989); desta amostra foi separada pirita para analises $\mathrm{Sr}-\mathrm{Sr}$, Sm-Nd e $\mathrm{Pb}-\mathrm{Pb}$.

Sistemática Sr-Sr: As razões ${ }^{87} \mathrm{Sr}{ }^{86} \mathrm{Sr}$ nas piritas são bem maiores do que no carbonato. A razão ${ }^{87} \mathrm{Sr} /{ }^{86} \mathrm{Sr}$ das piritas foram: 0,7121 (FHD-14, mina La Mona); e 0,70710 (amostra FHD-16, mina Villonza). Nos carbonatos da amostra FHD-16, a razão ${ }^{87} \mathrm{Sr} /{ }^{86} \mathrm{Sr}$ foi bem menos radiogênica com um valor de 0,70466 (Tabela 6).

Sistemática Sm-Nd: Os valores do parâmetro $\varepsilon_{N d(0)}$ são distintas para as duas minas amostradas. A pirita da amostra FHD-14 (mina La Mona), apresentou $\varepsilon_{\mathrm{Nd}(0)}$ de 2,46, com razões ${ }^{143} \mathrm{Nd} /{ }^{144} \mathrm{Nd}$ de 0,512512 e razão ${ }^{147} \mathrm{Sm} /{ }^{144} \mathrm{Nd}$ de 0,1316 ; resultado este que indica um aporte de fluidos provenientes de rochas da crosta superior na formação desses sulfetos. Na pirita da amostra FHD-16 (Mina Villonza), o valor do $\varepsilon_{\mathrm{Nd}(0)}$ calculado foi de $+2,46$, com razão ${ }^{143} \mathrm{Nd} /{ }^{144} \mathrm{Nd}$ de 0,512764 e razão ${ }^{147} \mathrm{Sm} /{ }^{144} \mathrm{Nd}$ de 0,1315; sendo os resultados similares aos obtidos no Veio2 do setor de Marmato Bajo (Tabela 7). 

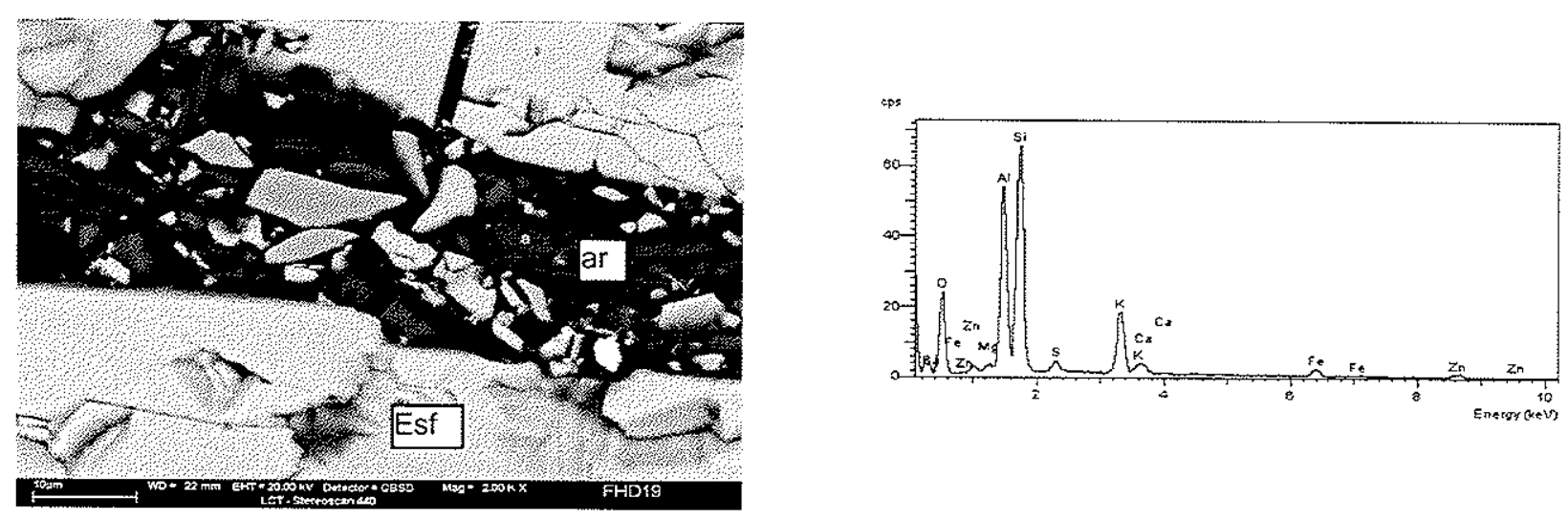

Figura 43. Argilominerais (ar) preenchendo fratura em esfalerita (Esf). Imagem ES do MEV.
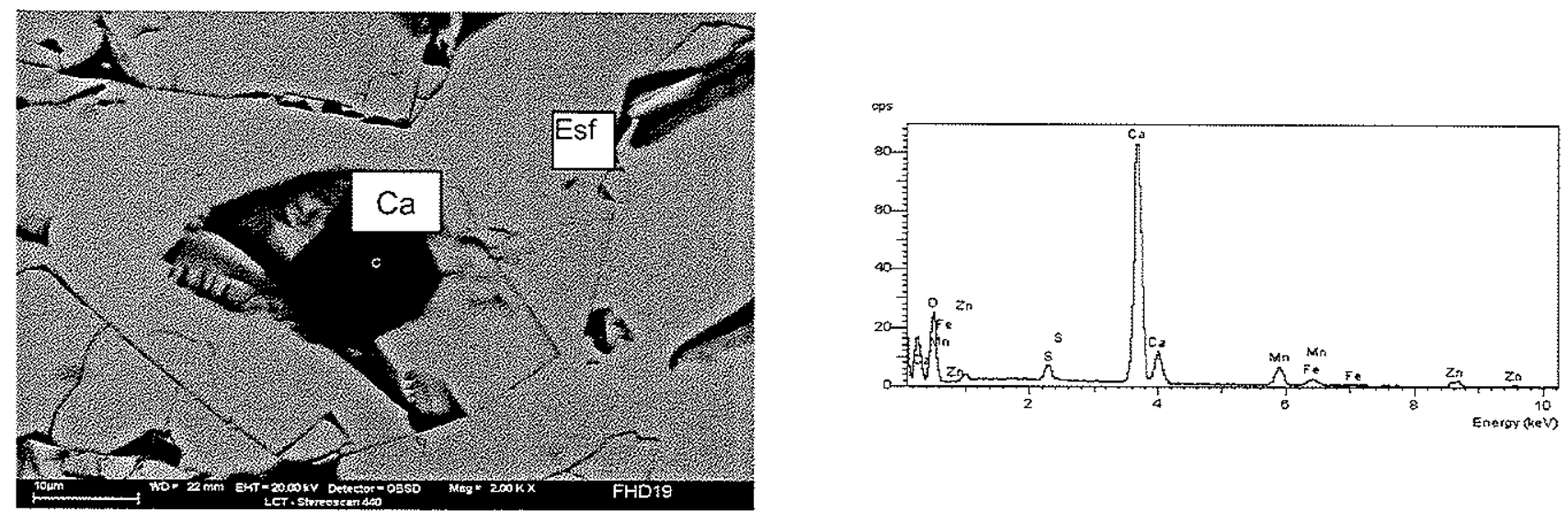

Figura 44. Microcristal de calcita(ca) dentro de esfalerita (Esf), Imagem ES do MEV. 
Sistemática $P b-P b:$ A pirita da mina Villonza, apresentou valores mais radiogênicos entre todos os sulfetos estudados, sendo as razões ${ }^{206} \mathrm{~Pb} /{ }^{204} \mathrm{~Pb}$, ${ }^{207} \mathrm{~Pb} /{ }^{204} \mathrm{~Pb}$ e ${ }^{208} \mathrm{~Pb} /{ }^{204} \mathrm{~Pb}$ de: $19,258,15,910$, e 39,751 respetivamente. A pirita da mina La Mona, foi mais radiogênica do que as piritas do setor de Marmato Bajo, apresentando razões ${ }^{206} \mathrm{~Pb} /{ }^{204} \mathrm{~Pb},{ }^{207} \mathrm{~Pb} /{ }^{204} \mathrm{~Pb}$ e ${ }^{208} \mathrm{~Pb} /{ }^{204} \mathrm{~Pb}$ de: $19,067,15,726$ e 39,208 respetivamente (Tabela 8 ).

\subsubsection{Setor de Echandía (parte superficial)}

Na mina Plata Fria (Setor de Echandía), foram coletadas as amostras FHD-1 e FHD-2. A amostra FHD-1 corresponde a um veio de carbonatos com alguns sulfetos, e a amostra FHD-2 corresponde a um veio de $2 \mathrm{~cm}$ de sulfetos dentro de rocha encaixante com alteração fillica e silicificação; segundo Buenaventura (1997) as direções principais dos veios e fraturas mineralizadas deste setor são de N40W e N70W. Da amostra FHD-1 foram separados carbonatos para analises $\mathrm{Sr}-\mathrm{Sr}$ e da amostra FHD-2 foram separadas piritas para analises $\mathrm{Pb}-\mathrm{Pb}$ e $\mathrm{Sm}-\mathrm{Nd}$; e esfalerita e galena para analises $\mathrm{Pb}-\mathrm{Pb}$.

Sistemática Sr-Sr e Sm-Nd: A razão isotópica ${ }^{87} \mathrm{Sr} /{ }^{86} \mathrm{Sr}$ do carbonato da amostra FHD-1 foi de 0,70472 , a mais radiogênica de todos os carbonatos. A pirita da amostra FHD-2 apresentou valores negativos de $\varepsilon_{\mathrm{Nd}(0)},-1,1$, e razăo ${ }^{143} \mathrm{Nd} /{ }^{144} \mathrm{Nd}$ pouco radiogênica, com valor de $0,512581, \mathrm{e}^{147} \mathrm{Sm} /{ }^{144} \mathrm{Nd}$ de 0,1241 ; resultados que indicam um aporte de fluidos derivados das rochas da crosta superior na formação destas piritas (Tabela 6, 7).

Sistemática $\mathrm{Pb}-\mathrm{Pb}$ : Os valores isotópicos obtidos pela sistemática $\mathrm{Pb}-\mathrm{Pb}$ para a galena foram os menos radiogênicas de todos os minerais analisados, as razões ${ }^{206} \mathrm{~Pb} /{ }^{204} \mathrm{~Pb},{ }^{207} \mathrm{~Pb} /{ }^{204} \mathrm{~Pb}$ e ${ }^{208} \mathrm{~Pb} /{ }^{204} \mathrm{~Pb}$ foram respectivamente de: $19,003,15,605$ e 38,813. As esfaleritas da amostra FHD-2 foram mais radiogênicas do que as esfaleritas da amostra FHD-19 (setor de Marmato Bajo), apresentando razões ${ }^{206} \mathrm{~Pb} /{ }^{204} \mathrm{~Pb}$, 
${ }^{207} \mathrm{~Pb} /{ }^{204} \mathrm{~Pb}, \mathrm{e}^{208} \mathrm{~Pb} /{ }^{204} \mathrm{~Pb}$ de: $19,100,15,715$ e 39,170 . Na pirita da amostra FHD-2, foi obtido razões ${ }^{206} \mathrm{~Pb} /{ }^{204} \mathrm{~Pb},{ }^{207} \mathrm{~Pb} /{ }^{204} \mathrm{~Pb}$ e ${ }^{206} \mathrm{~Pb} /{ }^{204} \mathrm{~Pb}$ de: $19,058,15,715$ e 39,209, respectivamente; o valor da razão ${ }^{208} \mathrm{~Pb} /{ }^{204} \mathrm{~Pb}$ da amostra FHD-2 (pirita), foi o mais radiogênico entre todas as amostras estudadas, com exceção da amostra FHD-16 (Tabela 8).

\subsection{ROCHAS ENCAIXANTES}

As rochas encaixantes analisadas isotópicamente para comparação com a composição isotópica dos minérios, compreendem; xistos grafitosos, xistos quartzo biotíticos, xistos Anfibolíticos do Complexo Arquia; rochas ultramáficas; diorito do Stock de Támesis, o Dacito Andesito Pórfiro de Marmato e basaltos da Formação Combia.

\subsubsection{Xistos do Complexo Arquía}

Deste Complexo, as amostras FHD-6, CJ-03 e CJ-06, foram analisadas pelas sistemáticas $\mathrm{Sr}-\mathrm{Sr}, \mathrm{Sm}-\mathrm{Nd}$ e $\mathrm{Pb}-\mathrm{Pb}$; e a amostra CJ-04 somente para: $\mathrm{Sr}-\mathrm{Sr}$ e $\mathrm{Sm}-\mathrm{Nd}$. A amostra FHD-6 e a CJ-03, coletadas no setor de Echandia e no córrego Chirapoto correspondem a um xisto grafitoso e a um xisto quartzo biotítico, respectivamente.

Os xístos grafitosos e os xistos quartzo biotíticos apresentaram as razões ${ }^{87} \mathrm{Sr} /{ }^{86} \mathrm{Sr}$ mais elevadas, sendo de 0,73510 para os xistos grafitosos e de 0,71491 para os xistos quartzo biotiticos. Os valores do parâmetro $\varepsilon_{\mathrm{Nd}(0)}$ para essas rochas foram os menores de todas as unidades; nos xistos quartzo biotíticos o valor do $\varepsilon_{\mathrm{Nd}(0)}$ foi de $-12,91$ e nos xistos grafitosos de $-11,26$. Os valores isotópicos na sistemática $\mathrm{Pb}-\mathrm{Pb}$ para os xistos quartzo biotíticos foram os mais radiogênicos de todas as unidades, com razões ${ }^{206} \mathrm{~Pb} /{ }^{204} \mathrm{~Pb},{ }^{207} \mathrm{~Pb} /{ }^{204} \mathrm{~Pb}$ e ${ }^{208} \mathrm{~Pb} /{ }^{204} \mathrm{~Pb}$ respectivamente de: $19,652,15,702$ e de 39,118 . Enquanto que os xistos grafitosos, apresentaram valores pouco menos radiogênicos, em relação ao $\mathrm{Pb}$ uranogênico e thoriogênico. As idades modelo $\mathrm{Sm}-\mathrm{Nd}$, TDm foram de 1,9 Ga para os xistos grafitosos e de 1,7 Ga para os xistos quartzo biotíticos, esses valores indicam a média da idade de diferenciação mantélica dos 
diversos protolitos crustais das fontes dos xistos grafitosos e dos xistos quartzo biotíticos.

As amostras CJ-04 e CJ-06 foram coletadas, no córrego Chirapoto ao norte de Marmato e correspondem a xistos Anfibolíticos.

Os xistos Anfibolíticos (hornblenda xistos) as amostras CJ-04 e CJ-06, apresentam baixas razões ${ }^{87} \mathrm{Sr} /{ }^{86} \mathrm{Sr}$, de 0,70430 e 0,70620 , altos valores do parâmetro $\varepsilon_{\mathrm{Nd}(0)}$, de $+10,61$ e $+0,31$, respectivamente; e na amostra $\mathrm{CJ}-06$ razões ${ }^{206} \mathrm{~Pb} /{ }^{204} \mathrm{~Pb}$, ${ }^{207} \mathrm{~Pb} /{ }^{204} \mathrm{~Pb}$ e ${ }^{208} \mathrm{~Pb} /{ }^{204} \mathrm{~Pb}$ de: $19,131,15,609$ e 38,807 , respectivamente. A amostra CJ04 é interpretada como derivada de protolitos pouco diferenciados, possivelmente originados no manto empobrecido; alem o processo de milonitização nessa amostra, no afeito as razões ${ }^{87} \mathrm{Sr} /{ }^{86} \mathrm{Sr}$ e ${ }^{143} \mathrm{Nd} /{ }^{144} \mathrm{Nd}$. A amostra CJ-06 corresponde a uma rocha mais diferenciadas, possivelmente teve mistura ou contaminação com material mais diferenciado, proveniente de rochas da crosta, pelo qual aumento a razão ${ }^{87} \mathrm{Sr} /{ }^{86} \mathrm{Sr}$ e diminuiu a razão ${ }^{143} \mathrm{Nd} /{ }^{144} \mathrm{Nd}$ e pelo tanto o $\varepsilon_{\mathrm{Nd}(0)}$ desta amostra (Tabela $6,7,8$ ).

\subsubsection{Rochas ultramáficas}

As rochas ultramáficas analisadas correspondem às amostras CJ-02 e IGM6912. A amostra CJ-02 localiza-se na córrego Chirapoto, corresponde a um piroxenito, e foi analisada pelas sistemáticas Sr-Sr e Sm-Nd. A amostra IGM-6912, localiza-se na via de entrada do município de Marmato, pela rodovia Pan-Américana; corresponde a um dunito serpentinizado, analisado pelas sistemáticas Sr-Sr e Nd-Nd.

O dunito serpentinizado (amostra IGM-6912) apresentou razão ${ }^{87} \mathrm{Sr} /{ }^{86} \mathrm{Sr}$ de 0,70475 e valor $\varepsilon_{\mathrm{Nd}(0)}$ de $+4,45$; indicando uma possível fonte do manto empobrecido. $O$ piroxenito (amostra CJ-02) apresentou razão ${ }^{87} \mathrm{Sr} /{ }^{86} \mathrm{Sr}$ de 0,706841 e valor do parâmetro $\varepsilon_{\mathrm{Nd}(0)}$ de $+10,32$. As razões isotópicas, desta amostra, estão indicando uma fonte pouco diferenciada do manto empobrecido; mas a razão ${ }^{87} \mathrm{Sr} /{ }^{86} \mathrm{Sr}, 0,7068$, pode ser considerada um pouco elevada para os piroxenitos; segundo Calle et al. (1984), as rochas ultramáficas poderiam representar complexos ofiolíticos, pelo qual a elevada razão ${ }^{87} \mathrm{Sr} /{ }^{86} \mathrm{Sr}$, pode ser interpretada como devida a processos de alteração hidrotermal oceânica, os quais afeitam a composição isotópica original do Sr, mas não a 
composição isotópica do Nd (DePaolo, 1988); outra possivel interpretação poderia ser, por contaminação na composição do Sr na colocação do corpo do piroxenito na zona de cizalhamento, o corpo é pequeno $(2 \mathrm{~m})$ e encontra-se em contato com o dacito andesito pórfiro (Tabela 6,7 ).

\subsubsection{Stock de Támesis}

A amostra IGM-8763 pertence ao Stock de Támesis (fácies gabroides até quartzo dioríticas), localiza-se ao oeste do Marmato, sul do município de Támesis e foi analisada pelas sistemáticas $\mathrm{Sr}-\mathrm{Sr}, \mathrm{Sm}-\mathrm{Nd}$ e $\mathrm{Pb}-\mathrm{Pb}$.

As razões isotópicas do diorito hornbléndico (gabro) analisado apresentam valores pouco radiogênicos, sendo a razão ${ }^{87} \mathrm{Sr} /{ }^{86} \mathrm{Sr}$ de 0,703876 , valor este similar aos valores isotópicos dos Arcos de llhas vulcânicos, 0,70386 (Faure, 1986). O parâmetro $\varepsilon_{\mathrm{Nd}(0)}$ foi de $+3,80$, indicando uma fonte pouco diferenciada. Os resultados isotópicos das razões ${ }^{206} \mathrm{~Pb} /{ }^{204} \mathrm{~Pb},{ }^{207} \mathrm{~Pb} /{ }^{204} \mathrm{~Pb}$ e ${ }^{208} \mathrm{~Pb} /{ }^{204} \mathrm{~Pb}$ foram: $19,028,15,561$ e 38,745, respectivamente (Tabela $6,7,8$ ).

\subsubsection{Formação Combia}

Da Formação Combia foi analisado pelas sistemáticas $\mathrm{Sr}-\mathrm{Sr}$ e $\mathrm{Sm}-\mathrm{Nd}$ o basalto da amostra IGM-119089, localizado ao SW do município de Jardín, oeste do Marmato. Esta rocha apresenta razões ${ }^{87} \mathrm{Sr} /{ }^{86} \mathrm{Sr}$ baixas, da ordem de 0,703957 , e valor do parâmetro $\varepsilon_{\mathrm{Nd}(0)}$ de $+4,68$; indicando fontes magmáticas pouco diferenciadas (Tabela 6 , 7).

\subsubsection{Dacito Andesito Pórfiro do Stock de Marmato}

Deste corpo foram analisadas pelas sistemáticas $\mathrm{Sr}-\mathrm{Sr}, \mathrm{Sm}-\mathrm{Nd}$ e $\mathrm{Pb}-\mathrm{Pb}$ três amostras, CJ-01, CJ-66A e IGM-6921. A amostra CJ-01 corresponde a um Pórfiro 
Latítico, a amostra CJ-66A corresponde a um Dacito Pórfiro e localizam-se ao norte do Marmato no córrego Chirapoto; a amostra IGM-6921 corresponde a um microquartzodiorito Porfirítico e localizamse ao oeste do Marmato.

Os resultados isotópicos foram bastante homogêneos nas três sistemáticas. As razões isotópicas ${ }^{87} \mathrm{Sr}{ }^{86} \mathrm{Sr}$ foram baixas, entre 0,70445 e 0,70459 , valores similares aos de rochas derivadas de arcos magmáticos continentais, 0.70437 (Faure,1986). O valor do parâmetro $\varepsilon_{\mathrm{Nd}(0)}$ esteve entre $+2,22$ e $+3,20$. Os resultados isotópicos obtidos para está amostra, estão indicando fontes magmáticas pouco diferenciadas.

As razões isotópicas $\mathrm{Pb} / \mathrm{Pb}$ dos Andesito Dacito Pórfiros apresentaram valores homogêneos e pouco radiogênicos; as razões ${ }^{206} \mathrm{~Pb} /{ }^{204} \mathrm{~Pb},{ }^{207} \mathrm{~Pb} /{ }^{204} \mathrm{~Pb}$ e ${ }^{208} \mathrm{~Pb} /{ }^{204} \mathrm{~Pb}$ variaram respectivamente entre: 18,964 e 18,$982 ; 15,564$ e 15,579 e 38,640 e 38,688 (Tabela $6,7,8$ ).

\subsection{DISCUSSÕES}

\subsubsection{Idade da mineralização}

A idade $\mathrm{K}-\mathrm{Ar}$ de 5,6 \pm 0,6 Ma obtida no plagioclásio sericitizado da amostra FHD24, permite relacionar a mineralização com o ambiente geológico e tectônico no qual foi formada; em particular com a atividade magmática, assim como a atividade tectônica do Sistema de Falhas de Cauca Romeral.

O magmatismo associado à Formação Combia ocorreu entre 10,6 e 6,3 Ma; sendo que ao norte do Marmato, encontram-se rochas com idades entre 10,6 e 7,8 Ma, como o Andesito Pórfiro do Corcovado e o basalto do Cangrejo (Restrepo et al., 1981; MacDonald, 1980; Jaramillo, 1978); já ao sul e no setor de Marmato, ocorrem corpos com idades entre 7,1 e 6,3 Ma (Vinasco, 2001; Restrepo et al., 1981; González, 1976). A idade obtida para a mineralização de 5,6 $\pm 0,6 \mathrm{Ma}$, corresponde à finalização da atividade magmática na parte norte da depressão do Cauca-Patia; posterior a essa fase, o magmatismo migrou ao leste, ao eixo da Cordilheira Central (sul do $5^{\circ} \mathrm{N}$ ), onde atualmente se localiza a atividade vulcânica nos Andes Colombianos. 
Vinasco (2001), apresentou datações Ar-Ar para um andesito pórfiro localizado ao sul do Marmato e para um anfibolito deformado localizado ao norte de Marmato, com

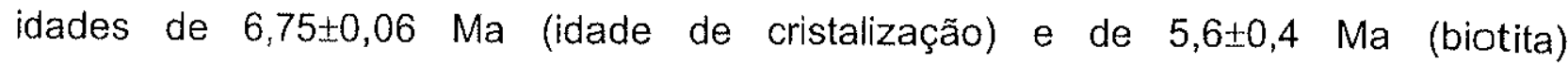
respetivamente; as quais interpretou como relacionadas ao último evento de reativação do Sistema de Falhas na região. A idade de 5,6 \pm 0,6 obtida para a mineralização de Marmato, estaria relacionada por tanto, com a fase final da evolução tectônica do Sistema de Falhas Cauca-Romeral na região e da formação do Stock de Marmato.

Segundo os dados geocronológicos, o resfriamento do Andesito Dacito Pórfiro de Marmato, se originou antes de terminar a atividade tectônica de Sistema de Falhamento de Cauca Romeral; o qual permitiu o fraturamento e a formação de veios distencionais, fraturas e diaclases nesse corpo subvulcânico. Os veios mineralizados no setor de Marmato apresentam direções entre NW (Veio1, Mellizos), até NWW-EW (Veio2, Ovejo); essas variações poderiam estar indicando diferentes pulsos das deformações, que dado o caráter sinistral do sistema de Falhamentos de Cauca Romeral, poderia indicar que os veios com orientação E-W poderiam ser mais antigos do que os veios com orientação NW, que deveriam ser mais recentes. Ao finalizar a atividade magmática, as fontes de calor finais, originaram circuitos hidrotermais que permitiram a percolação e circulação de fluidos nas fraturas previamente formadas, originando desta forma os veios mineralizados.

\subsubsection{Veios Auríferos}

Como visto no capítulo 5; os veios mineralizados apresentam zoneamento lateral, nas paredes dos veios ocorrem bandas de pirita, e na parte central são encontradas bandas de esfalerita; e entre estas bandas ocorrem os outros sulfetos e os minerais de ganga; por vezes ocorrem em fraturas brechas hidrotermais preenchidas de carbonato (López-Rendón e Bedoya, 1989; López-Rendón, 1991). Na seqüência paragenética são reconhecidas três fases principais na formação dos minerais, na primeira fase (F1) predominou a formação de pirita (Py1), a segunda fase (F2) caracteriza-se pela formação de esfalerita, e a terceira fase (F3), pela formação de pirita tardia (Py2) e carbonato. Entre as fases 2 e 3 ocorreu um evento deformacional no 
setor de Marmato Bajo (Bedoya, 1998) e no setor de Echandia, López-Rendón (1991) considera-a ocorrência de um evento de formação de brechas hidrotermais.

\subsubsection{Setor de Marmato Bajo}

No setor de Marmato Bajo, os resultados obtidos pelas diferentes sistemáticas isotópicas, apresentaram variaçōes de acordo com o mineral analisado, e com o veio no qual foi coletada a amostra. Os resultados obtidos para as piritas na sistemática Sm-Nd foram homogêneos, com poucas variações; os resultados obtidos pela sistemática $\mathrm{Pb}$ $\mathrm{Pb}$ apresentaram variações de acordo ao veio no qual foi coletada a amostra; na sistemática $\mathrm{Sr}$-Sr; as variações observadas foram de acordo ao mineral analisado. Inicialmente serão discutidos os resultados de acordo à seqüência paragenética dos minerais, posteriormente para cada veio.

Fase 1(F1). As piritas relacionadas à primeira fase paragenética, apresentaram valores de $\varepsilon_{\mathrm{Nd}(0)}$ entre $+1,95$ e $+3,28$, que são similares aos valores calculados para os pórfiros do Stock de Marmato $(+2,22$ e $+3,20)$, o que sugere que estas rochas tenham uma contribuição importante como fonte dos fluidos hidrotermais envolvidos. Por outro lado os valores obtidos para a razão ${ }^{87} \mathrm{Sr}{ }^{86} \mathrm{Sr}$ das piritas são bastante variáveis, situando-se entre 0,70500 e 0,70930, o que indica que o sistema hidrotermal circulou por rochas com razão $\mathrm{Rb} / \mathrm{Sr}$ mais elevada, como por exemplo os xistos quartzo biotíticos (razões ${ }^{87} \mathrm{Sr} /{ }^{86} \mathrm{Sr}$ de 0,71491 ) ou os xistos grafitosos (razões ${ }^{87} \mathrm{Sr} /{ }^{86} \mathrm{Sr}$ de 0,73510); ou outra unidade da crosta superior. Como o $\mathrm{Sm}$ e o $\mathrm{Nd}$, elementos do grupo das terras raras, são muito menos solúveis que o $\mathrm{Sr}$, a composição isotópica $\mathrm{Nd} / \mathrm{Nd}$ e o valor do $\varepsilon_{N d(0)}$, não foram modificados significativamente neste processo de interação fluido rocha (Figura 45).

Os dados isotópicos de $\mathrm{Pb}$ nas piritas, corroboram com a hipótese de circulação do sistema hidrotermal pelas rochas da crosta superior, com altas razões ${ }^{87} \mathrm{Sr} /{ }^{86} \mathrm{Sr}$. Os valores quando lançados no diagrama ${ }^{207} \mathrm{~Pb} /{ }^{204} \mathrm{~Pb}$ e ${ }^{208} \mathrm{~Pb} /{ }^{204} \mathrm{~Pb}$ versus ${ }^{206} \mathrm{~Pb} /{ }^{204} \mathrm{~Pb} d a$ Figura $(46,47)$, onde encontram-se lançadas como referência, as curvas de evolução 


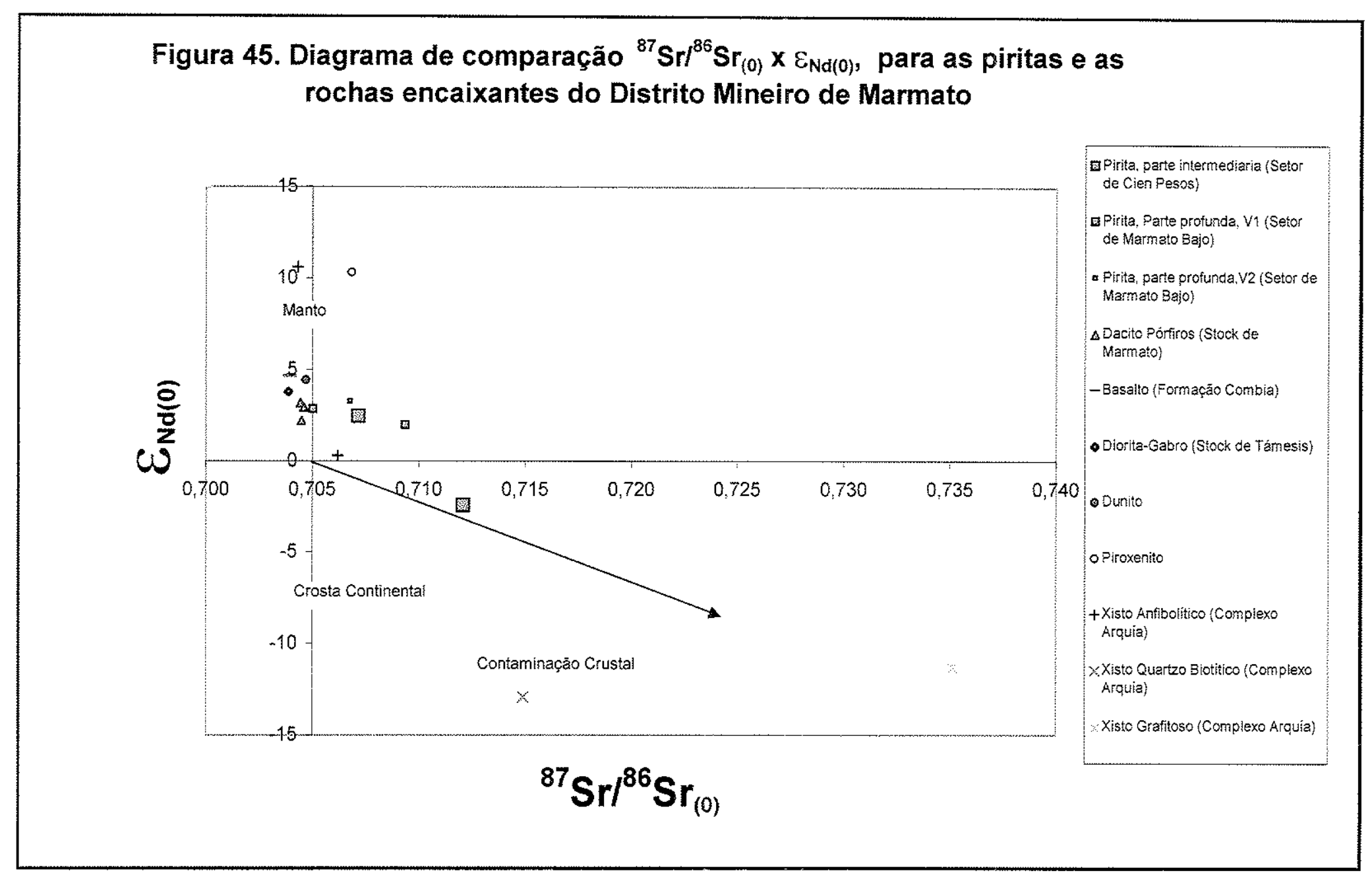




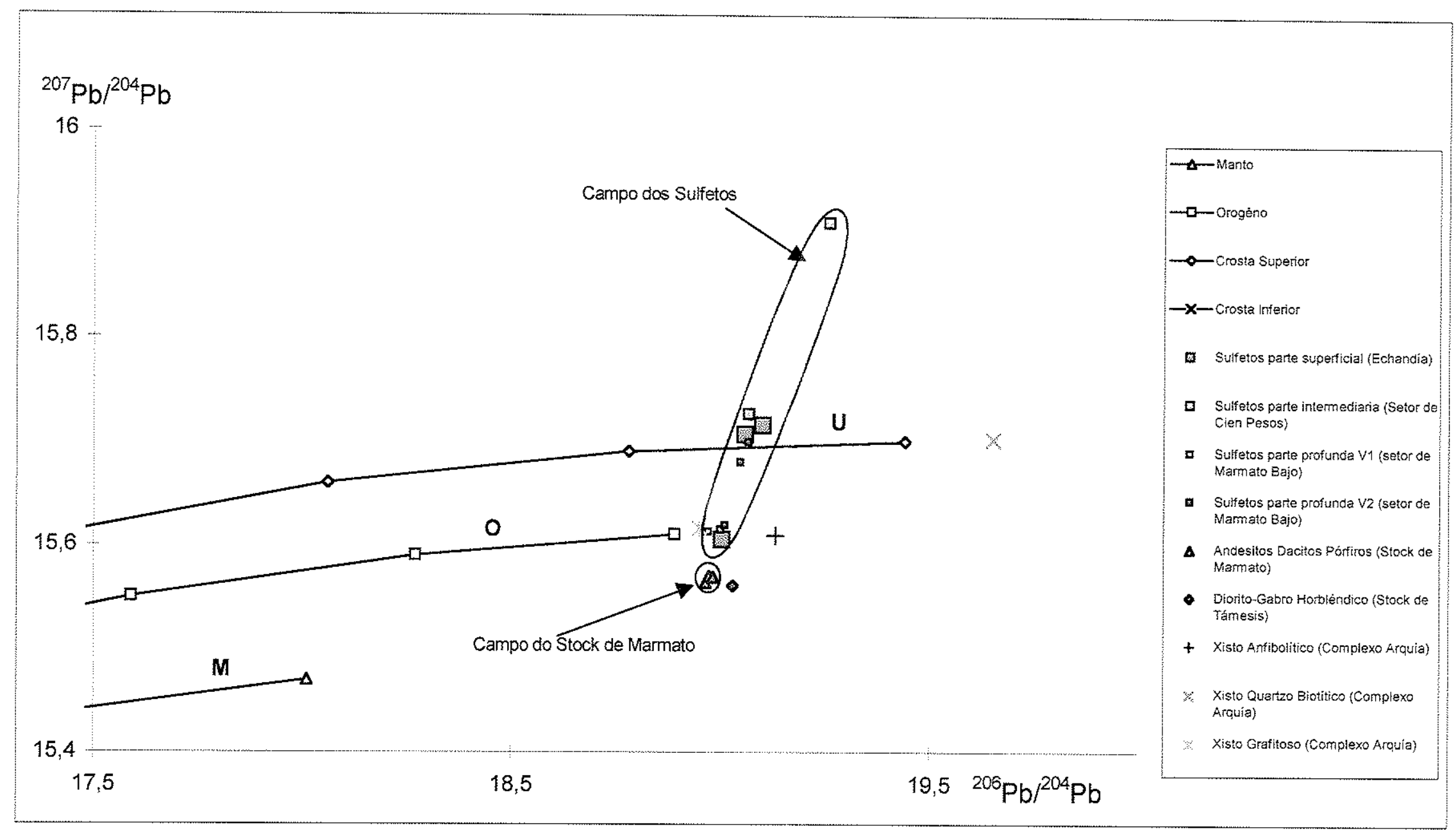

Figura 46. Diagrama Uranogênico com os pontos relativos aos sulfetos e das rochas regionais em relação as curvas da Plumbotectônica de Zartman e Doe (1981) 


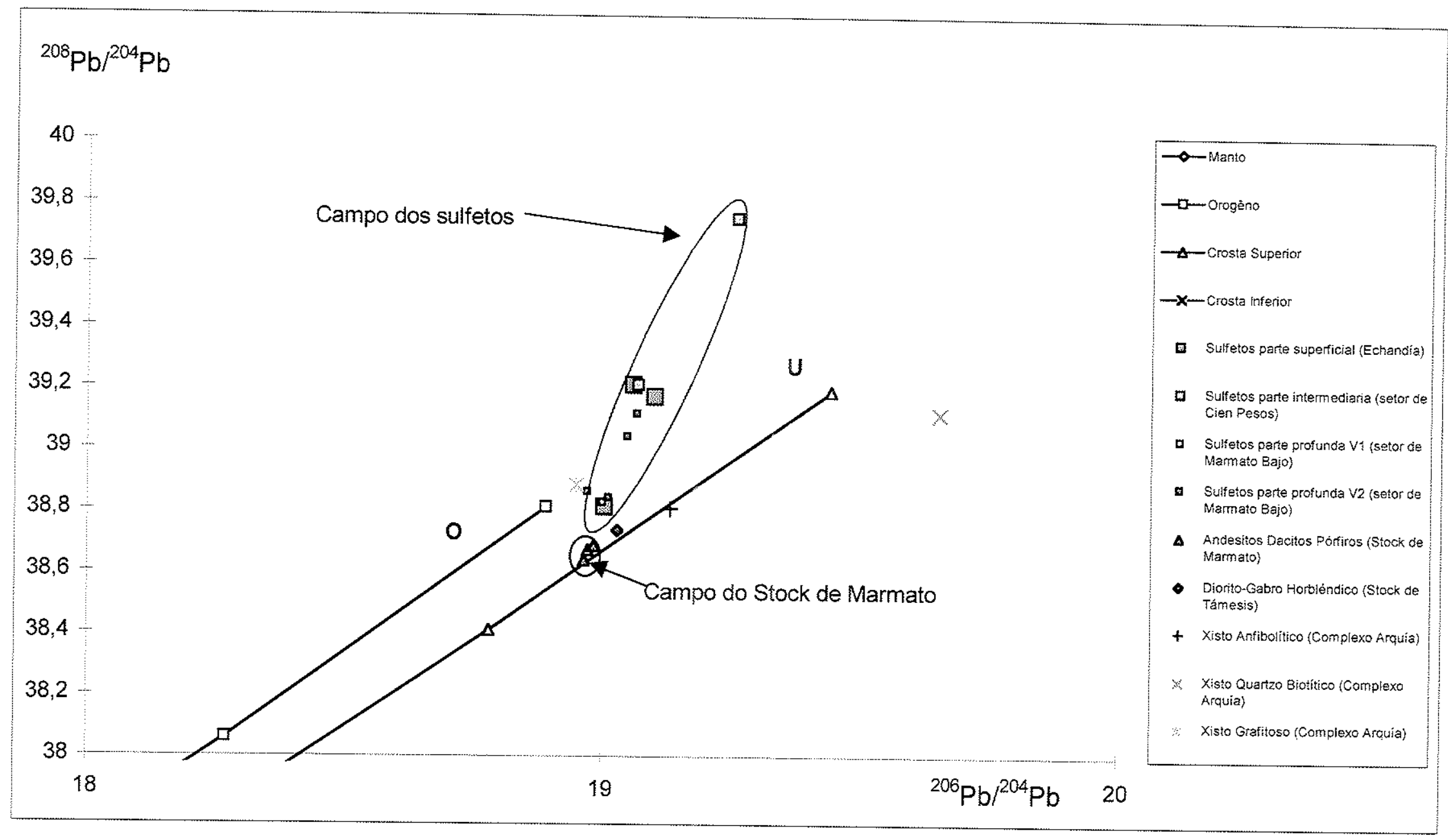

Figura 47. Diagrama Thoriogênico com os pontos relativos aos sulfetos e as rochas regionais em relação as curvas da Plumbotectônica de Zartman e Doe (1981) 
do $\mathrm{Pb}$ estabelecidas pelo modelo da Plumbotectônica de Zartman e Doe (1981), mostram claramente que o $\mathrm{Pb}$ incorporado nos sulfetos, foi originado de uma mistura entre os pórfiros e rochas da crosta superior. Considerando-se a composição isotópica do $\mathrm{Pb}$ dos xistos grafitosos, pode-se sugerir que estas rochas ao exemplo dos isótopos de $\mathrm{Sr}$, participaram do evento de circulação hidrotermal. As piritas com composição de $\mathrm{Pb}$ mais radiogênica, mostram que incorporaram $\mathrm{Pb}$ de rochas com razão U/Pb mais elevada do que o xisto grafitoso, mas também pode pertencer ao Complexo Arquía.

Fase 2 (F2). Na seqüência paragenética, a esfalerita foi formada na fase 2 (F2). No setor de Marmato Bajo, a esfalerita da amostra FHD-19 foi analisada pela sistemática $\mathrm{Pb}-\mathrm{Pb}$ e $\mathrm{Sr}$-Sr; as razões ${ }^{87} \mathrm{Sr} /{ }^{86} \mathrm{Sr}$ da esfalerita (dissolução total) e dos seus dois primeiros lixiviados ( $L 1$ e $L 2$ ) foram entre 0,70500 e 0,70590; esses valores comparados com as razões ${ }^{87} \mathrm{Sr}{ }^{86} \mathrm{Sr}$ dos andesitos dacitos pórfiros (entre 0,70445 e 0,70459); são pouco mais radiogênicos, os fluidos tiveram como fonte as rochas Porfíricas com mistura subordinada de outras rochas com razões ${ }^{87} \mathrm{Sr} /{ }^{86} \mathrm{Sr}$ um pouco maiores. As razões ${ }^{87} \mathrm{Sr}{ }^{86} \mathrm{Sr}$ das esfaleritas, originadas na $\mathrm{F} 2$ da seqüência paragenética, são menores do que as razões ${ }^{87} \mathrm{Sr} /{ }^{86} \mathrm{Sr}$ das piritas originadas na $\mathrm{F} 1$; isto pode ser interpretado como indicativo de uma circulação mais restrita dos fluidos na formação das esfaleritas, não afetando as rochas metasedimentares, como no caso das piritas da F1. Esta interpretação ainda é preliminar em virtude de ter como base apenas as analises isotópicas de uma amostra. Este fato também é evidenciado pelos isótopos de $\mathrm{Pb}$, que mostraram para a esfalerita valores menos radiogênicos do que aqueles obtidos para as piritas da F1. O posicionamento do ponto da esfalerita no diagrama ${ }^{207} \mathrm{~Pb} /{ }^{204} \mathrm{~Pb}$ versus ${ }^{206} \mathrm{~Pb} /{ }^{204} \mathrm{~Pb}$ sugere que a fonte do $\mathrm{Pb}$ fosse o pórfiro com uma participação subordinada do xisto grafitoso ou do xisto Anfibolítico que possui razão ${ }^{87} \mathrm{Sr} /{ }^{86} \mathrm{Sr}$ de 0,70620 (Tabela 6, Figura 46, 47).

Fase (3). Na seqüência paragenética os carbonatos são interpretados como pertencentes à fase $3(F 3)$ na formação dos minerais. No setor de Marmato Bajo, foram analisados carbonatos de uma brecha hidrotermal e dos veios mineralizados. As razões 
${ }^{87} \mathrm{Sr} /{ }^{86} \mathrm{Sr}$ obtidas foram similares de 70440 e 0,70450 ; esses valores, são concordantes com os resultados obtidos para os andesitos dacitos pórfiros do Stock de Marmato, o que mostra que a circulação destes fluidos envolveu apenas este stock. Neste caso pode-se interpretar como evento responsável pela formação dos carbonatos, um pulso final da atividade magmatica-hidrotermal, relacionado aos corpos subvulcânicos (Tabela $6)$.

Veios. Com o objetivo de comparar ás composições isotópicas dos sulfetos provenientes de veios mineralizados com orientação distintas (Veio1-Mellizos, NW; Veio2-Ovejo, NWW) foi elaborado o diagrama ${ }^{207} \mathrm{~Pb} /{ }^{204} \mathrm{~Pb}$ e ${ }^{208} \mathrm{~Pb} /{ }^{204} \mathrm{~Pb}$ versus ${ }^{206} \mathrm{~Pb} /{ }^{204} \mathrm{~Pb}$ da Figura $(48,49)$. Neste diagrama observa-se que as composições isotópicas do $\mathrm{Pb}$ das piritas pertencentes ao Veio1 possuem valores ${ }^{207} \mathrm{~Pb} /{ }^{204} \mathrm{~Pb}$ menos radiogênicos do que ás do Veio2, no diagrama situam-se próximas da composição do xisto grafitoso; já os sulfetos provenientes do Veio2 possuem razões isotópicas ${ }^{207} \mathrm{~Pb} /{ }^{204} \mathrm{~Pb}$ mais radiogênicas, mostrando que suas possiveis fontes incluiram rochas com maior razão $U / \mathrm{Pb}$.

Nas piritas do Veio1, as razões ${ }^{87} \mathrm{Sr}{ }^{86} \mathrm{Sr}$ variaram entre 0,70506 e 0,70930 e no Veio 2 entre 0,70451 e 0,70670 ; o parâmetro $\varepsilon_{\mathrm{Nd}(0)}$ no Veio1 variou entre $+1,95$ e $+2,85$ e no Veio2 entre $+2,79$ e $+3,28$; estes dados indicam que as mineralizações do Veio2, com orientação NWW, tiveram uma circulação de fluidos hidrotermais, mais restrita, envolvendo preferencialmente as rochas do dacito pórfiro, mas com mistura na composição isotópica do $\mathrm{Sr}$, de rochas da crosta superior, dos xistos do Complexo Arquía.

\subsubsection{Setor de Cien Pesos}

No setor de Cien Pesos foram analisadas as amostras FHD-16 da mina Villonza, a qual pode corresponder ao Veio2 do setor de Marmato Bajo; e a amostra FHD-14 da mina La Mona.

A pirita e o carbonato da amostra FHD-16, apresentaram razões ${ }^{87} \mathrm{Sr} /{ }^{86} \mathrm{Sr}$ de 0,70710 e 0,70466 respectivamente; e valor $\varepsilon_{\mathrm{Nd}(0)}$ de $+2,46$ (pirita). 


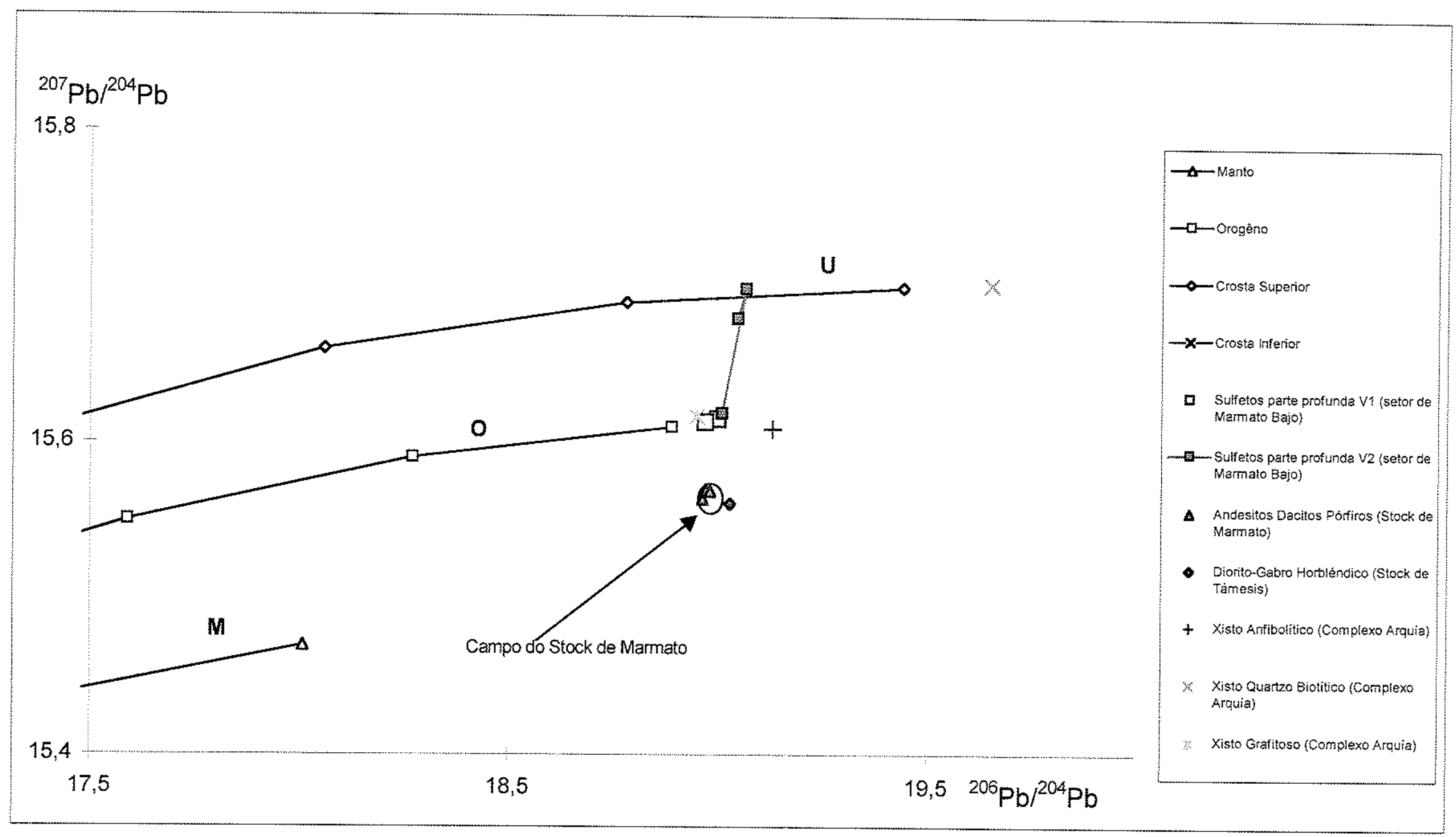

Figura 48. Diagrama Uranogênico com os pontos dos sulfetos do Veio 1(NW), Veio 2 (NWW) e das encaixantes do Distrito Mineiro de Marmato em relação as curvas da Plumbotectônica de Zartman e Doe (1981) 


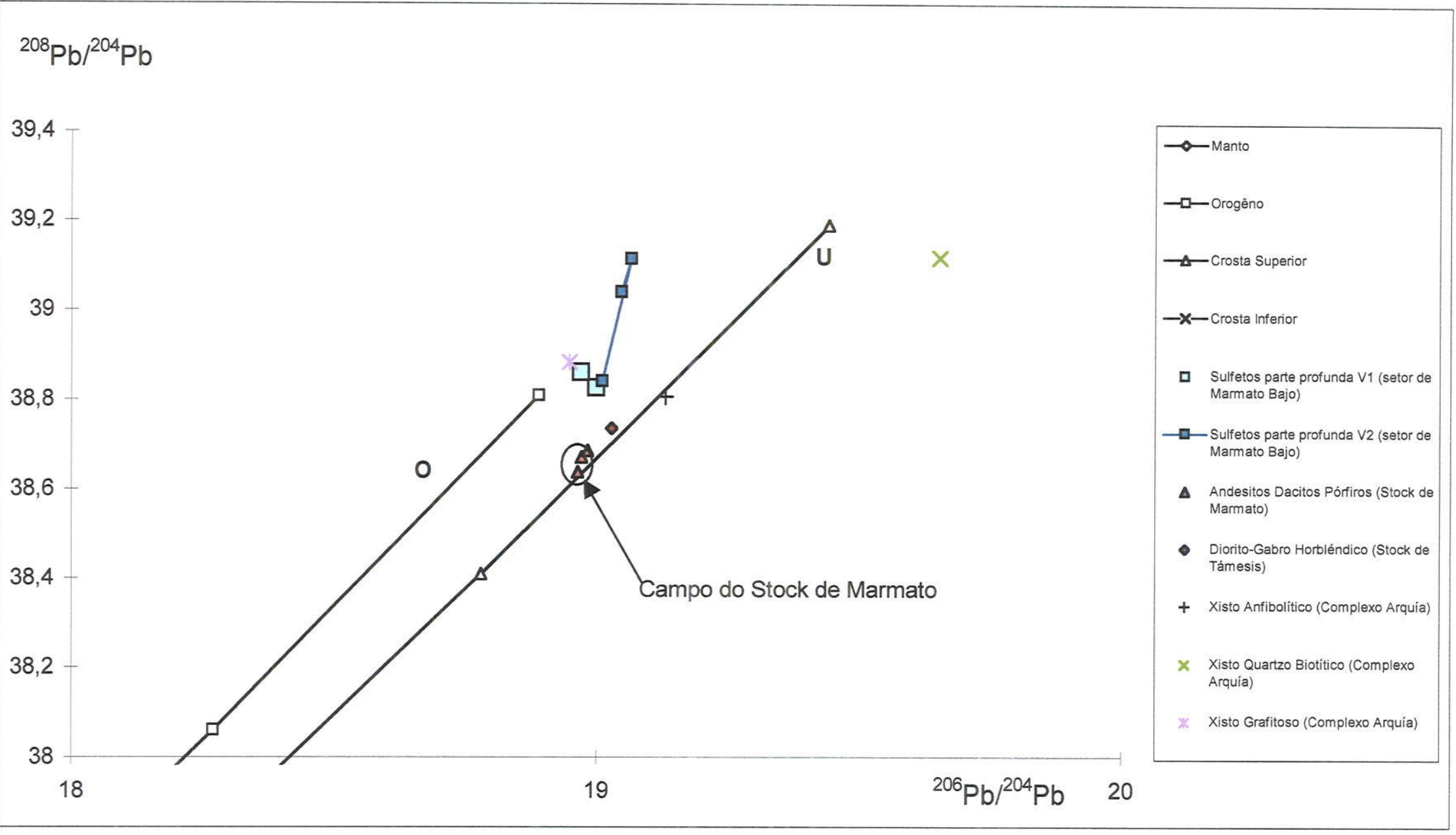

Figura 49. Diagrama Thoriogênico com os pontos dos sulfetos do Veio 1(NW), Veio 2 (NWW) e das encaixantes do Distrito Mineiro de Marmato em relação as curvas da Plumbotectônica de Zartman e Doe (1981) 
A composição isotópica do $\mathrm{Sr}$ no carbonato e o valor do $\varepsilon_{\mathrm{Nd}\langle 0\rangle}$ da pirita, estão indicando fluidos derivados dos andesitos dacitos pórfiros, na formação dessas piritas; já os valores isotópicos do $\mathrm{Sr}$ na pirita, maiores do que os carbonatos, sugerem a participação de fluidos derivados de rochas da crosta superior, interpretação similar à de o Veio2 do setor de Marmato Bajo. A pirita desta amostra apresentou composições isotópicas de $\mathrm{Pb}$ anômalas, extremadamente radiogênicas (Figura 46, 47), sugerindo uma fonte com alta razão $\mathrm{U} / \mathrm{Pb}$ e $\mathrm{Th} / \mathrm{Pb}$, como trata-se apenas de 1 amostra com estes valores, necessita-se de trabalhos adicionais para uma melhor caracterização da natureza das fontes envolvidas no processo.

As piritas da amostra FHD-14 apresentaram, razões isotópicas ${ }^{87} \mathrm{Sr} /{ }^{86} \mathrm{Sr}$ de 0,7121 e valor do parâmetro $\varepsilon_{\mathrm{Nd}(0)}$ de $-2,46$, indicando fluidos derivados rochas da crosta superior; os resultados das composições isotópica pela sistemática $\mathrm{Pb}-\mathrm{Pb}$ lançados no diagrama da Plumbotectônica, apresentam valores mais radiogênicos do que as amostras do setor de Marmato Bajo (Tabela 6 e 7, Figura 45, 46, 47).

\subsubsection{Setor de Echandía}

No setor de Echandia foram analisadas isotópicamente as amostras FHD-1 e FHD-2. O carbonato da amostra FHD-1, indicou razões ${ }^{87} \mathrm{Sr} /{ }^{86} \mathrm{Sr}$ de 0,70472 ; sugerindo que esse mineral da seqüência paragenética $F 3$, teve como fonte principal, a exemplo dos demais carbonatos os andesitos dacitos pórfiros. $O$ valor do parâmetro $\varepsilon_{N d(0)}$ de $-1,11$, nas piritas da amostra FHD-2, indicam uma fonte para os fluidos, principalmente de rochas típicas da crosta superior (Tabela 6,7 ).

Os sulfetos desta amostra apresentaram composições isotópicas de $\mathrm{Pb}$ variáveis em função da mineralogia (Tabela 8, Figura 46, 47). A galena apresentou a composição isotópica menos radiogênica entre todos os sulfetos; os valores lançados no diagrama da Plumbotectônica (Uranogênico e Thoriogênico), quando comparados com os resultados das rochas encaixantes, indicam como fonte para o chumbo, uma mistura do xisto grafitoso e dos andesitos dacitos pórfiros. Os valores das razões $\mathrm{Pb} / \mathrm{Pb}$ das esfalerita e pirita, da mesma amostra, foram muito mais radiogênicos do que os valores 
das galenas. As diferenças observadas entre as composições de $\mathrm{Pb}$ da Galena e da Esfalerita-Pirita são indicativas que estos minerais formaram-se a partir de fluidos hidrotermais distintos, o que implica em admitir, que embora muito próximos no tempo geológico, estes fluidos circularam em épocas diferentes.

\subsection{Comparações}

Foi realizada uma comparação das composições isotópicas obtidas neste estudo e às composições dos vulcões Ruiz e Galeras e alguns depósitos de tipo pórfiro (Colômbia), assim como às de alguns depósitos epitermais, do tipo pórfiro e do tipo VHMS do Equador, bem como com as suas rochas hospedeiras.

O vulcanismo atual nos Andes Colombianos, localiza-se na Corditheira Central (ao sul do $5^{\circ} \mathrm{N}$ ) e no sul do Pais a leste da Cordilheira Ocidental; representa o arco magmático atual formado pela subduç̧ão da placa de Nazca no território Sul Americano; para Aspden et al. (1987) é a continuação do magmatismo associado à Formação Combia (11 até $5 \mathrm{Ma}$, localizado entre as Cordilheiras Central e Ocidental). Segundo Ordoñez (2001) a similaridade entre as composições isotópicas do vulcanismo atual e das rochas da Formação Combia, indicariam que o magmatismo que originou essas rochas é similar áquele observado atualmente no arco vulcânico, e que a homogeneidade isotópica observada, independentemente da localização geográfica, sugeriria que a contaminação com material crustal, foi originada pela interação entre magmas derivados do manto e a base da crosta continental.

As composições isotópicas dos andesitos dacitos pórfiros do Marmato foram comparadas com os valores isotópicos obtidos por James e Murcia (1984) para os vulcões Ruiz e Galeras (Figura 50, 51, 52). No diagrama $\varepsilon_{\text {Nd(0) }}$ versus ${ }^{87} \mathrm{Sr} /{ }^{86} \mathrm{Sr}$ pode ser observada a similaridade dos valores isotópicos dos vulcões e dos corpos subvulcânicos, indicando uma fonte de tipo mantélica para essas rochas. As razões ${ }^{87} \mathrm{Sr} /{ }^{86} \mathrm{Sr}$ dos andesitos dacitos pórfiros parecem ser um pouco mais radiogênicas, possivelmente por maior contaminação crustal, devida à maior assimilação de ${ }^{87} \mathrm{Sr}$ das rochas encaixantes durante a cristalização dos corpos. 


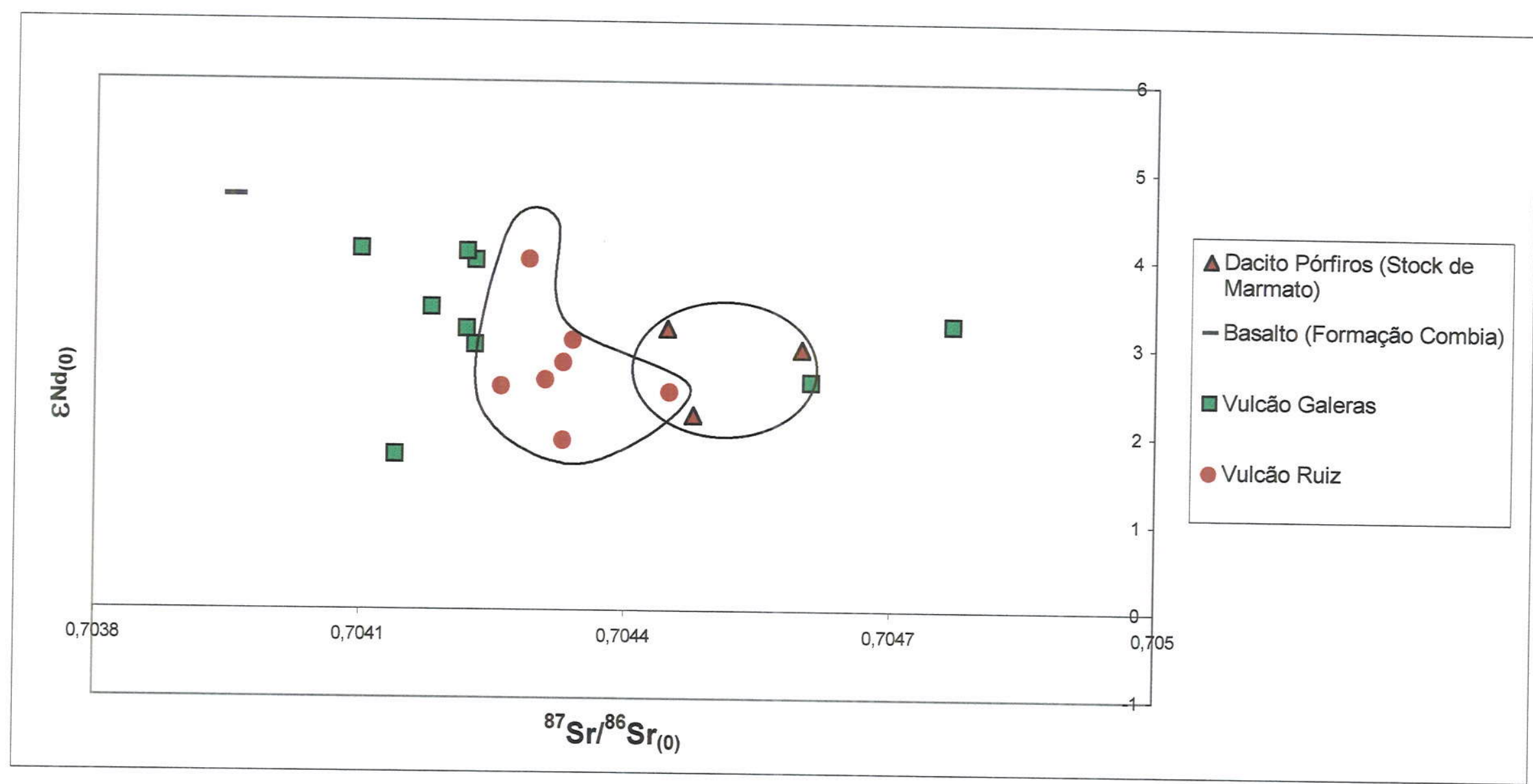

Figura 50. Diagrama de comparação dos valores de $\varepsilon_{\mathrm{Nd}(0)}{ }^{87} \mathrm{Sr}^{86} \mathrm{Sr}_{(0)}$ do Stock de Marmato e os Vulcões Galeras e Ruíz 


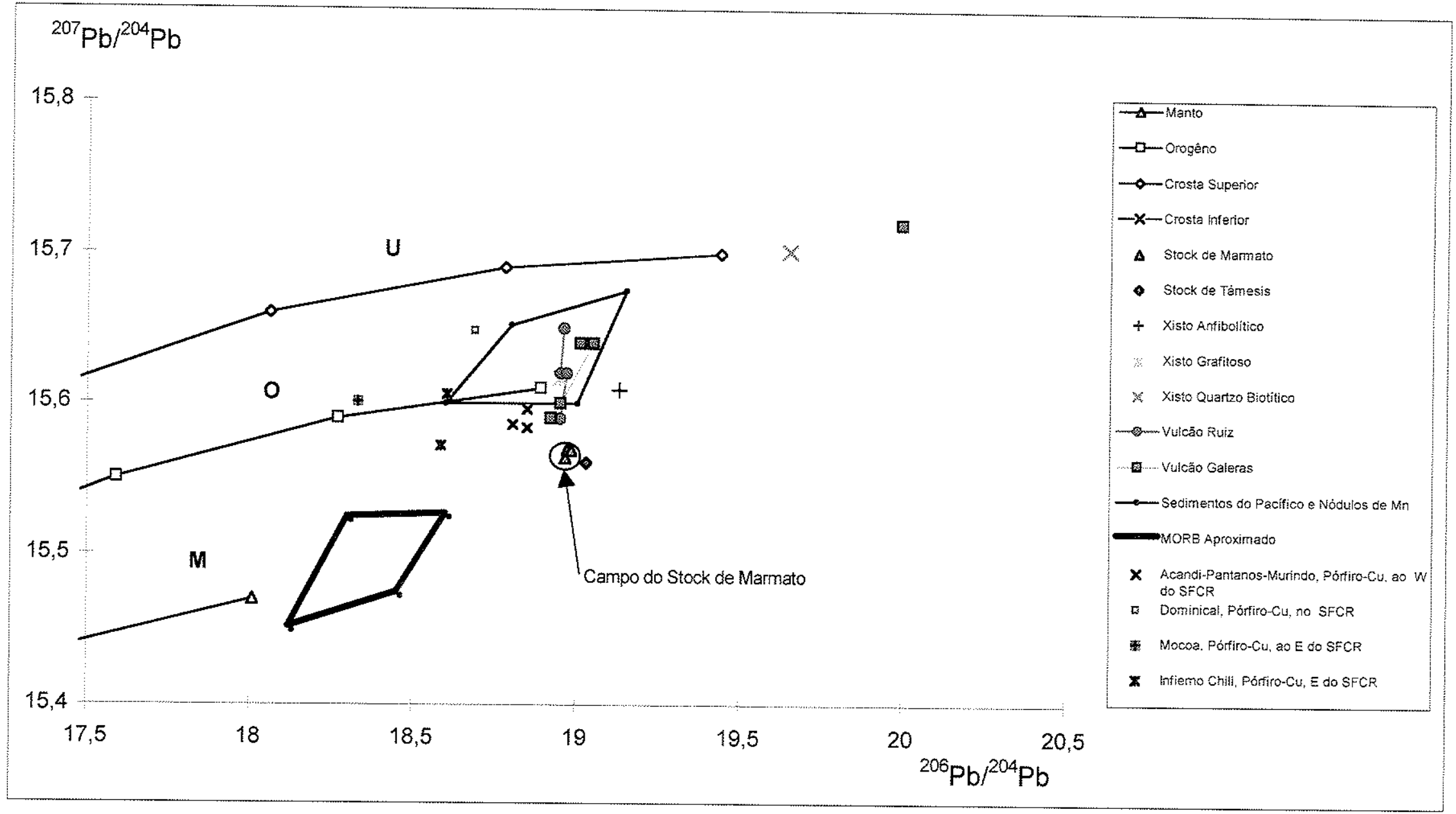

Figura 51. Comparação dos valores isotópicos do Distrito Minero de Marmato, dos Vulcões Galeras e Ruiz e de alguns depósitos tipo pórfiro da Colômbia, no Diagrama Uranogênico com as curvas de Zartman e Doe (1981) 


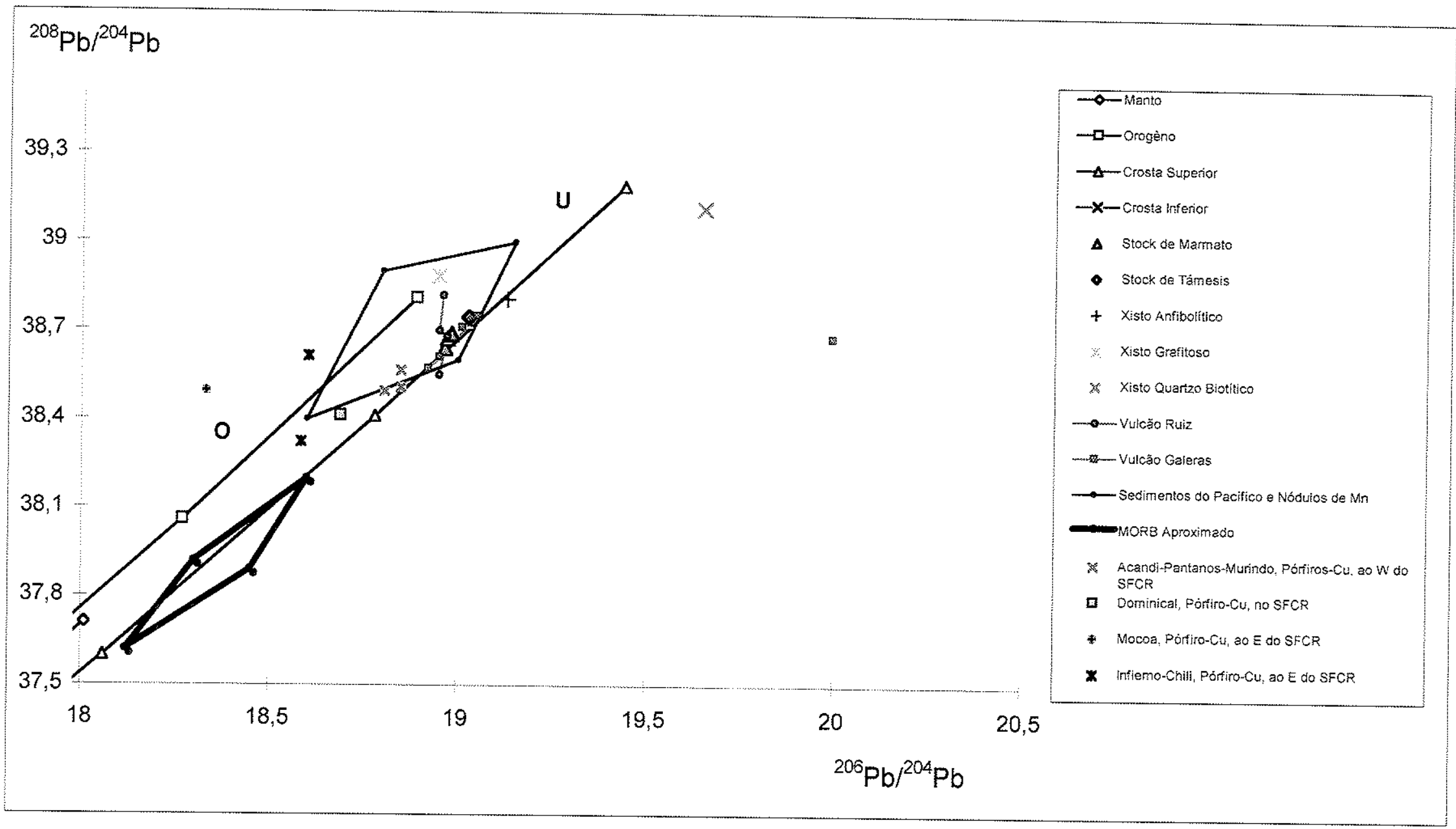

Figura 52. Comparação dos valores isotópicos do Distrito Minero de Marmato, dos Vulcões Galeras e Ruiz e alguns depósitos tipo pórfiro da Colômbia, no Diagrama Thoriogênico com as curvas de Zartman e Doe (1981) 
Já o basalto da Formação Combia é menos radiogênico na razão ${ }^{87} \mathrm{Sr} /{ }^{86} \mathrm{Sr}$, e mais radiogênico em relação aos isótopos de $\mathrm{Nd}$, indicando para o basalto uma menor contaminação crustal, possivelmente devida a uma ascenção mais rápida do magma para os niveis crustais mais elevados. No diagrama thoriogênico, é interessante observar a similaridade dos valores isotópicos dos vulcões, principalmente o Galeras, e os andesitos dacitos pórfiros; esses resultados indicam fontes com a razão $\mathrm{Th} / \mathrm{Pb}$ similar para ambas as rochas. No diagrama uranogênico os vulcões apresentam um comportamento mais radiogênico do que os corpos subvulcânicos, que pode ser devido ao fato de que os vulcões intrudem uma crosta superior com presença mais importante de rochas metasedimentares e metavulcânicas, possivelmente com altas razões U/Pb. Os valores isotópicos do Marmato comparados com os obtidos por Sillitoe e Hart (1984) para os depósitos tipo pórfiros de Acandi, Pantanos e Murindo localizados ao ocidente do Sistema de Falhas de Cauca-Romeral (SFCR), Dominical no SFCR, e Mocoa e Infierno-Chili localizados a leste do Sistema de Falhas de Romeral; não apresentaram similaridades importantes, indicando uma origem em ambientes geológicos e tempos diferentes.

Pode ser observado, que o magmatismo atual possui composição isotópica similar ao magmatismo que originou os andesitos dacitos pórfiros do stock de Marmato, implicando que a subducção da placa de Nazca, no continente Sul Americano, também originou os magmas que formaram os corpos subvulcânicos. Possivelmente a colocação dos magma em níveis superiores, esteve controlada pela reativação do Sistema de Falhas de Romeral, essa reativação pode formar bacias de tipo "pull apart" que permitiriam a ascenção dos magmas.

Os Andes setentrionais (Equador e Colômbia), que ocorrem ao norte da deflexão de Hancabamba (Golfo de Guayaquil), tiveram uma evolução tectônica similar, sendo caracterizada pela acreção sucessiva de arcos de ithas e platôs oceânicos desde o Jurássico (Ramos, 1999) ou desde o Cretácico (Litherland e Aspden, 1992; Litherland et al., 1994). Na Colômbia, o limite da acreção da crosta oceânica está localizado a oeste do Pais e é representado pelo Sistema de Falhas de Cauca Romeral (SFCR), que 
é uma estrutura principal que corta o Pais no sentido norte-sul, penetrando em território Equatoriano. Neste territorio, segundo Litherland e Aspden (1992), a Falha de Romeral corresponde à Falha de Peltetec, já a Falha de Cauca-Patia do SFCR corresponde ria à Falha de Pujili ou Calacali-Pallatanga. Entre estas duas falhas encontra-se uma depressão que percorre o território dos dois Países, sendo na Colômbia conhecida como depressão de Cauca Patía, e nela encontra-se localizado o stock de Marmato; no Equador é conhecida como depressão interandina. Litherland et al. (1994) divide o território de Equador em vários terrenos limitados por essas falhas; ao ocidente da falha Calacali-Pallatanga encontram-se os terrenos de Piñon (platô oceânico) e o terreno Macuchi (arco de ilhas oceânico), entre as falhas de Calacali-Pallatanga e Peltetec o terreno Chaucha (fragmentos de crosta continental) e a seqüência de margem continental de Guamote; a leste da falha de Peltetec o terreno Alao (arco de ilhas oceânico) e a seqüência de bacia marginal do Salado.

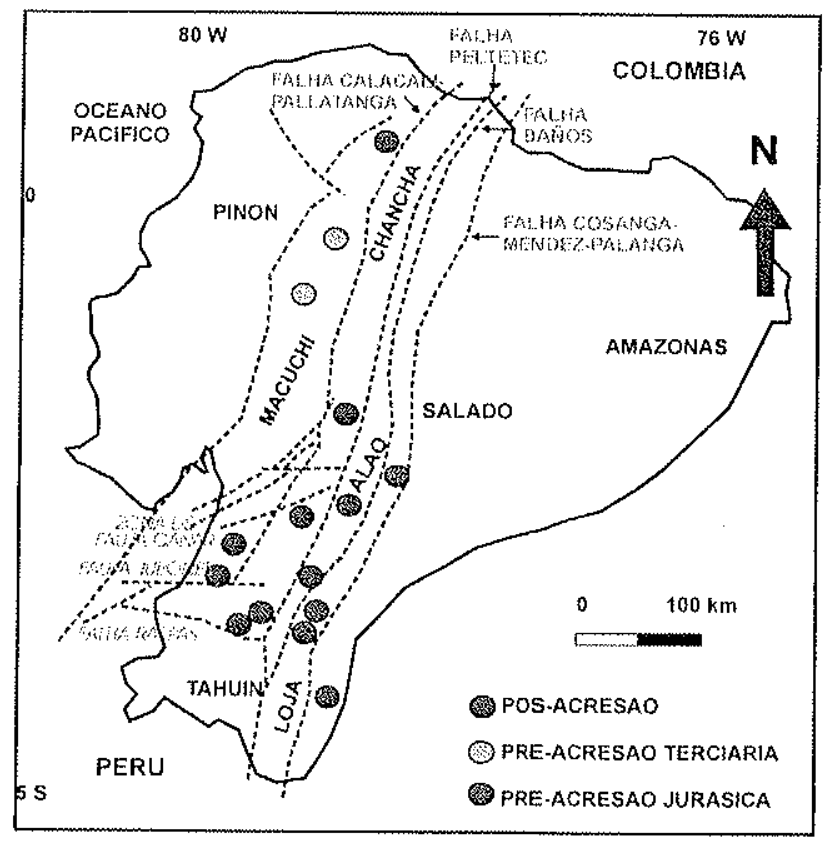

Figura 53. Localização Geotectónica dos depósitos estudados por Chiaradia e Fonboté (2001a, b). 
Chiaradia e Fontboté (2001a e 2001b) apresentaram dados isotópicos de Pb para depósitos tipo VHMS, pórfiro e epitermais associados aos terrenos definidos por Litherland et al. (1994) (Figura 53). Os sulfetos dos depósitos do Terciario inferior, tipo VHMS (rico em ouro) de La Plata, Macuchi e El Patiño, associados ao arco de ilhas oceânicas do terreno Macuchi, apresentam as mesmas composições isotópicas do que suas rochas hospedeiras, constituídas por basaltos e andesitas da unidade Macuchi principal. Esses autores interpretam essa associação isotópica e estratigrafica como indicador da fonte dos metais (unidade Macuchi principal); ademais os depósitos são internamente homogêneos isotópicamente, mas apresentam composições isotópicas diferentes entre eles, indicando células hidrotermais diferentes e pequenas (Figura 54 , 55). No depósito Jurássico de tipo VHMS Las Pilas associado ao arco de ilhas do terreno Alao, as composições isotópicas também estiveram relacionadas às rochas encaixantes, indicando a derivação do $\mathrm{Pb}$ da mineralização do basalto dessa unidade. Nos depósitos epitermais e do tipo pórfiro, associados ao magmatismo andino, o comportamento do $\mathrm{Pb}$ foi diferente; apresentando composições isotópicas das mineralizações mais diversas do que aquelas das encaixantes, invadindo o campo das rochas do embasamento, o que indicaria também a participação dessas rochas como fonte de $\mathrm{Pb}$ (Figura 56,57).

Pelo fato dos Andes do norte, na Colômbia e Equador, apresentar uma evolução tectônica similar, sem quer fazer nenhum tipo de correlação; foram comparadas as composições isotópicas obtidas por Chiaradia e Fontboté (2001a, 2001b) no Equador com os dados isotópicos obtidos neste estudo, o que permitiu fazer as seguintes observações: As composições isotópicas dos xistos garfitosos, quartzo biotítico e anfibolítico; foram similares as encontradas nas rochas metamórficas do terreno Chaucha, terreno Loja e do Complexo do Ouro. Os resultados dos sulfetos do Distrito de Marmato quando comparados com os depósitos do Equador (Figura 56, 57), apresentaram uma afinidade maior com os depósitos epitermais associados aos terrenos Chaucha e terreno Macuchi, assim como também a seus respectivos embasamentos. Chiaradia e Fontboté (2001a) consideram os xistos grafitosos da unidade Chiguinda, de idade Paleozóica como a possível fonte dos metais das mineralizações do terreno Chaucha. Na região de Marmato os xistos grafitosos do 


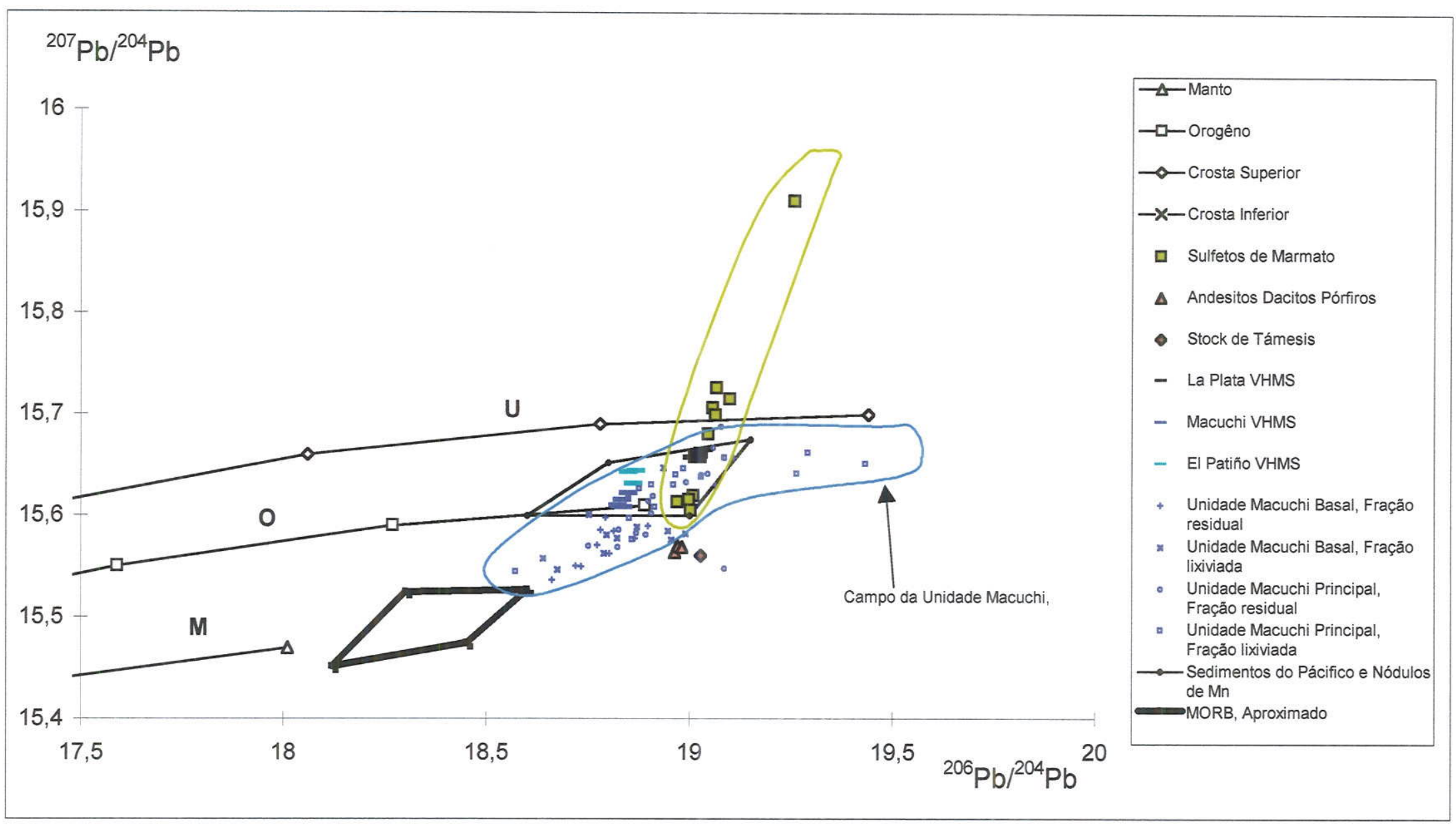

Figura 54. Comparação da composição Isotópica do Distrito Mineiro de Marmato e alguns depósitos tipo VHMS do Equador no Diagrama Uranogênico, com as curvas de Zartman e Doe (1981) 


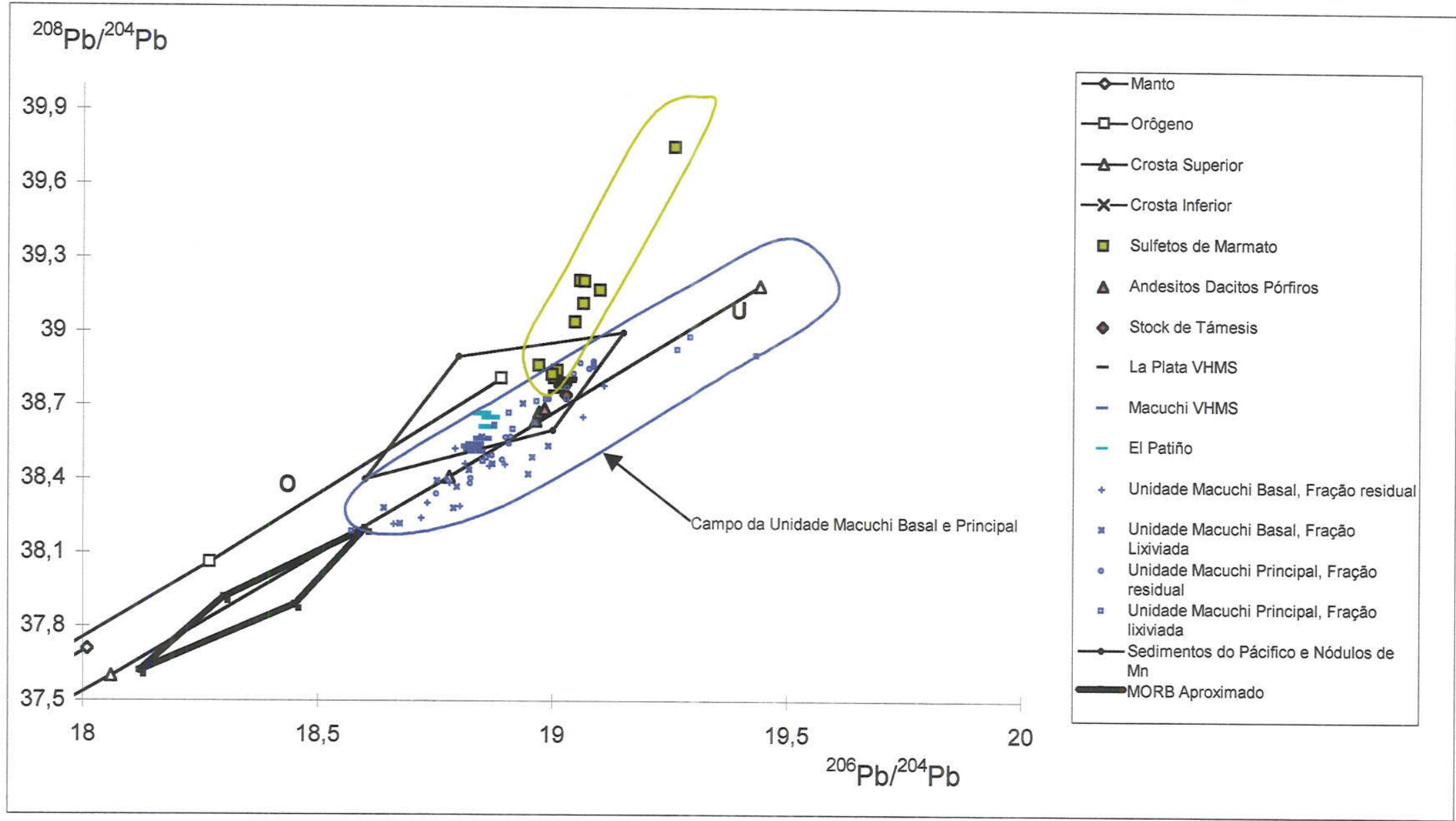

Figura 55. Comparação da composição Isotópica do Distrito Mineiro de Marmato e alguns depósitos tipo VHMS do Equador no Diagrama Thoriogênico, com as curvas de Zartman e Doe (1981) 


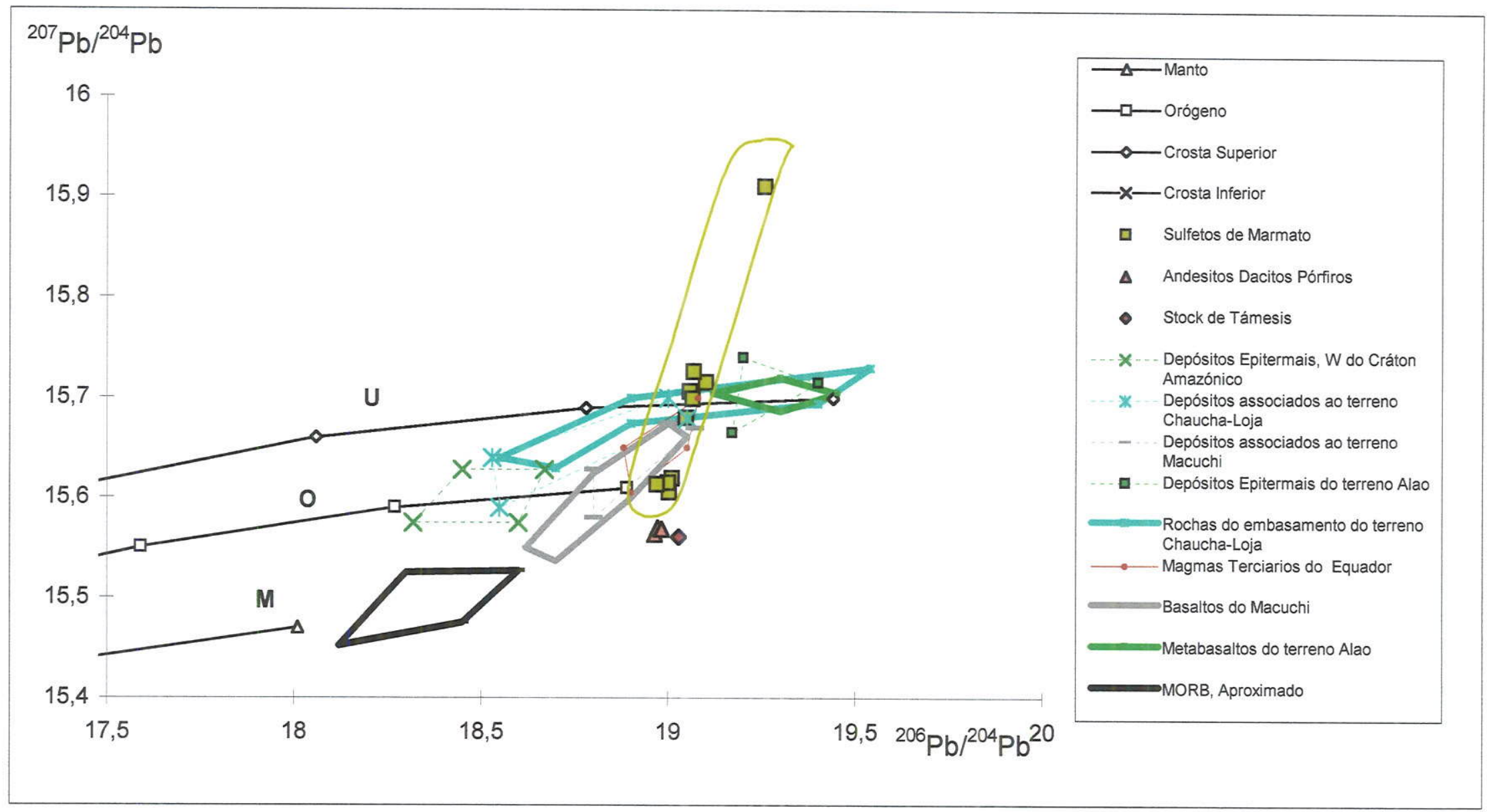

Figura 56. Comparação da composição isotópica do Distrito Mineiro de Marmato e alguns depósitos epitermais e tipo pórfiro do Equador, no Diagrama Uranogênico com as curvas de Zartman e Doe (1981) 


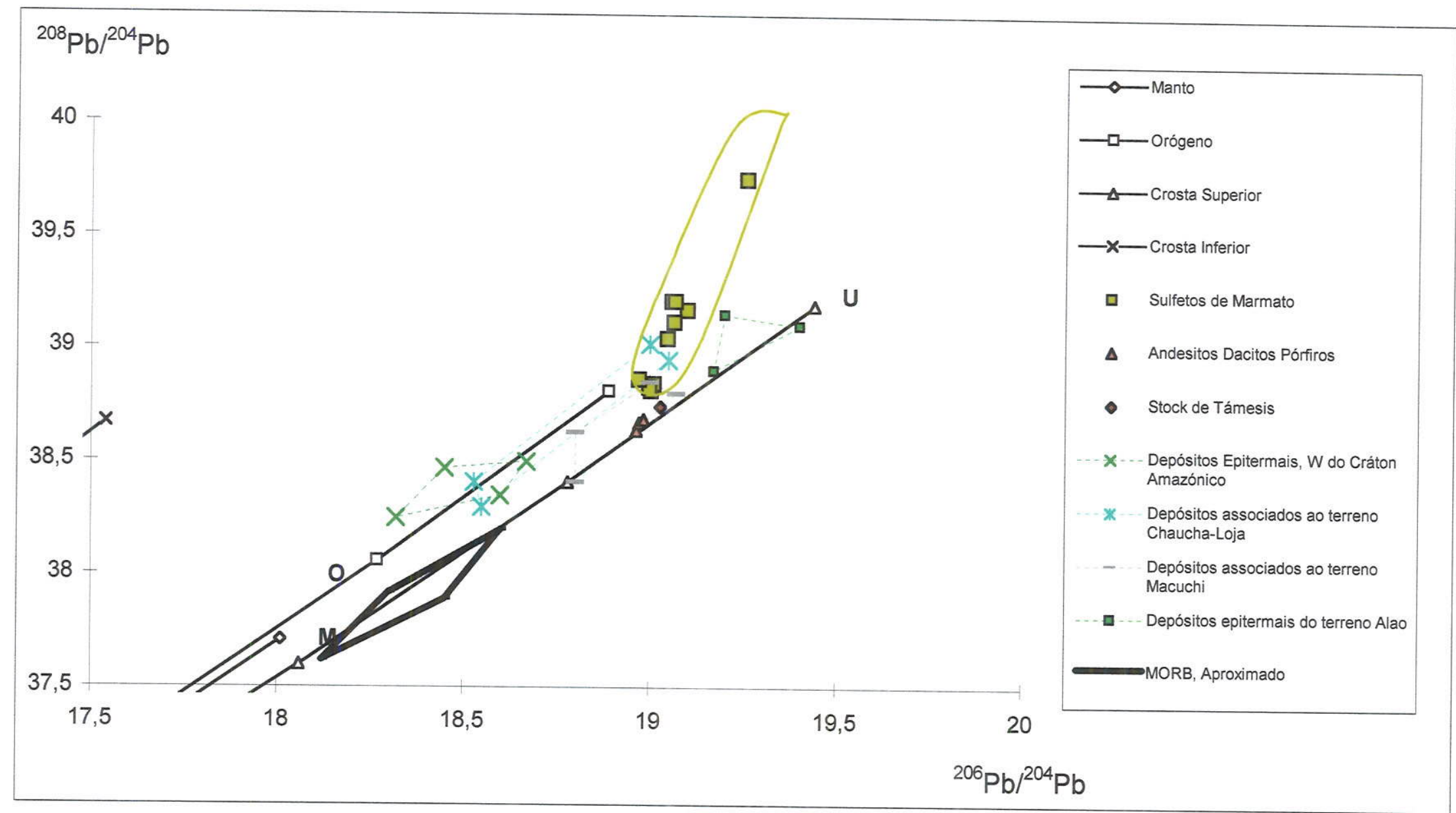

Figura 57. Comparação da composição isotópica do Distrito Mineiro de Marmato e alguns depósitos epitermais e tipo pórfiro do Equador, no Diagrama Thoriogênico com as curvas de Zartman e Doe (1981) 
Complexo Arquía, diferentemente do que ocorre no Equador, poderiam apenas ter contribuído como uma fonte subordinada para os fluidos mineralizantes, que estariam muito mais relacionadas as intrusões subvulcânicas. Na figura $(54,55)$ pode ser observado que os sulfetos do Distrito Mineiro de Marmato possuem composições isotópicas similares do depósito de tipo VHMS de La Pata no Equador, e com sua rocha encaixante. Entretanto estas mineralizações não podem ser comparadas, já que o contexto geológico que envolve as mineralizações é distinto; segundo Kerr et al. (2002) o arco do Macuchi pode corresponder ao arco do Timbiqui na Colômbia, localizado ao SW do Pais na margem ocidente da Cordilheira Ocidental. 


\section{CONSIDERAÇÕES FINAIS}

Com base nos dados geológicos e geocronológicos disponiveis na literatura (Ordoñez, 2001; Vinasco, 2001; Sierra et al, 2000; Duque-Caro, 1990; Restrepo et al., 1981; Paris e Romero, 1994; Ego et al., 1995) e nos dados isotópicos obtidos neste trabalho, podemos sumarizar á seguinte evolução tectônica e metalogenética para a região do Distrito Mineiro de Marmato (Fig 58, 59).

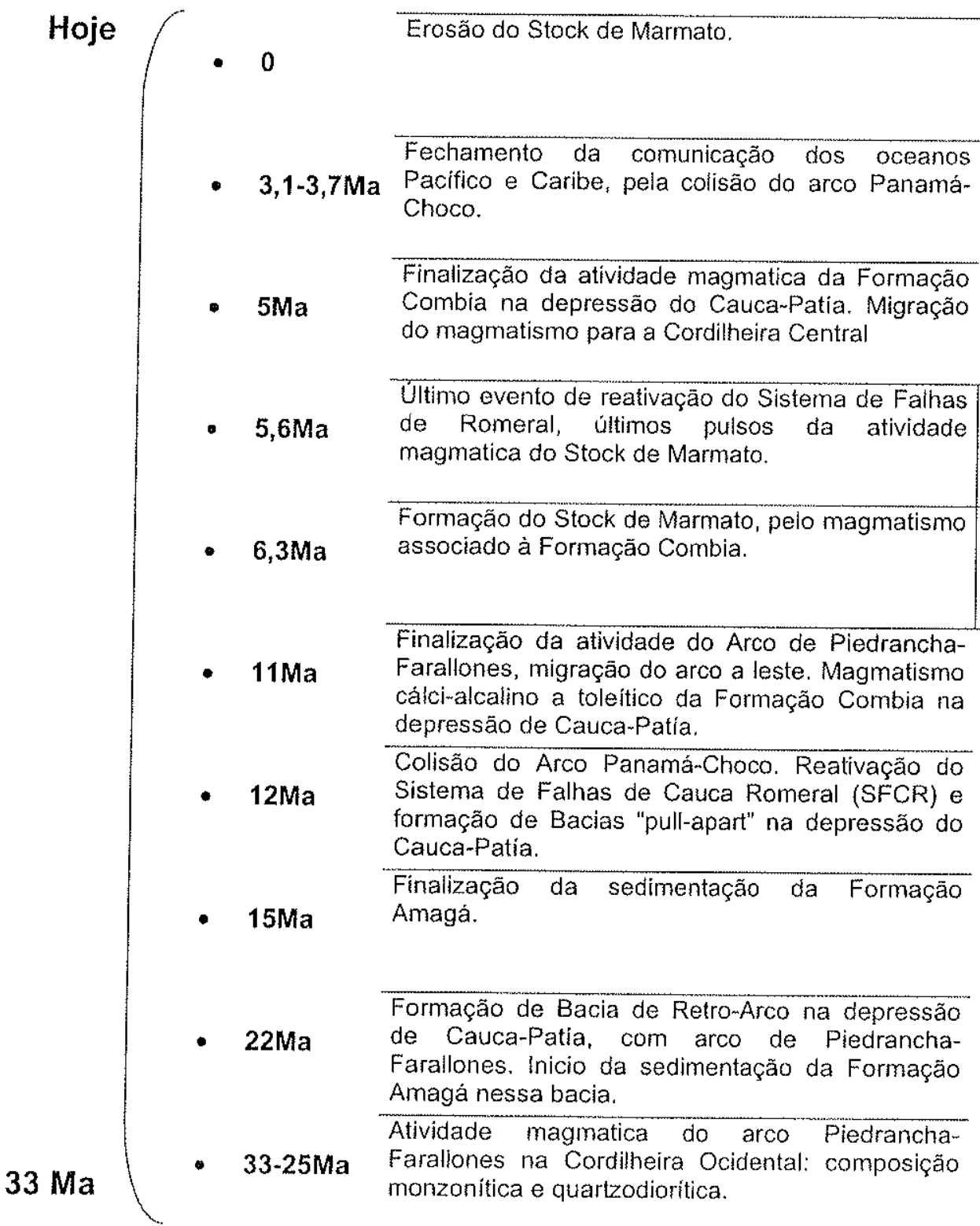

Figura 58. Síntese da Evolução tectónica e metalogenêtica 

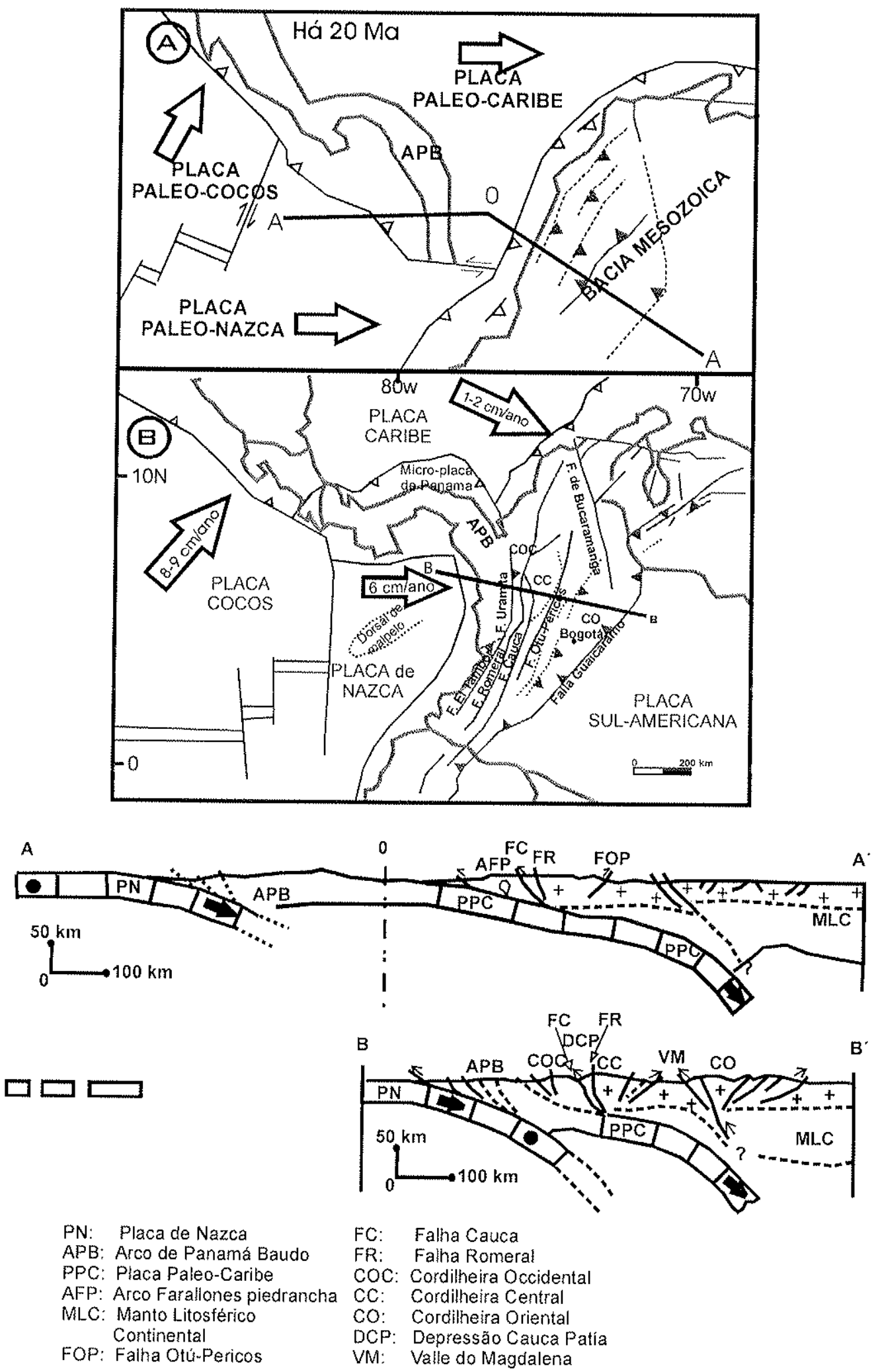

Figura 59. Diagrama de Evolução tectónica, 22Ma-Hoje (Taboada et al., 2000; Ordoñez, 2001) 
As mineralizações auríferas epitermais de Marmato são claramente relacionadas ao magmatismo dacítico do Miocêno superior, onde o sistema hidrotermal responsável pelo desenvolvimento das mineralizações envolveu principalmente as rochas subvulcânicas Porfíricas do Stock de Marmato, embora tenha também sido encontradas evidências isotópicas de que os xistos do Complexo Arquía (especialmente os xistos grafitosos) também foram afetados, pelo sistema hidrotermal. Isto implica também em considerar pelo menos parte das rochas encaixantes como possíveis hospedeiras de mineralizações auriferas. Está conclusão amplia os horizontes de exploração mineral para além dos limites do Stock de Marmato. Portanto, os dados isotópicos demonstram a relação genética entre o magmatismo porfíritico e a atividade hidrotermal, e que esta ativididade circulou também através das rochas mestassedimentares encaixantes das intrusões igneas. As características genéticas principais da formação das intrusões subvulcânicas e das mineralizações auríferas associadas se resume na Tabela 11.

Considerando-se uma semelhança entre os processos envolvendo as mineralizações miocênicas epitermais do Distrito de Marmato, que ocorre em ambiente de arco magmático, bacia de retro-arco e do tipo " pull apart" e as mineralizações auriferas epitermais, que ocorrem na Província Ventuari-Tapajós, considerada por Tassinari (1996) como um arco magmático paleoproterozóico, podemos por hipótese admitir que no Distrito de Marmato poderia ocorrer, em zonas mais profundas das rochas porfiríticas mineralizações auriferas disseminadas em zonas de "stockwork" e do tipo pórfiro, e por outro lado, na Província Aurífera do Tapajós, podem ocorrer mineralizações epitermais associadas a veios de quartzo não só nas rochas graníticas do Tipo Maloquinha, como também nas rochas sedimentares e vulcânicas das coberturas pré-cambrianas, uma vez que a circulação dos fluidos hidrotermais, apesar de induzidas pelas intrusões igneas, não se restringe a estas rochas, podendo produzir mineralizaçōes principalmente em zonas de cisalhamentos, que podem remobilizar fluidos do interior das rochas intrusivas. 


\section{Tabela 11. Modelo Genético das mineralizações auríferas do Distrito Mineiro de Marmato}

\begin{tabular}{|c|c|}
\hline \multicolumn{2}{|c|}{$\begin{array}{l}\text { MODELO GENETICO DAS MINERALIZACÔES AURIFERAS DO DISTRITO MINEIRO DE MARMATO } \\
\text { Características }\end{array}$} \\
\hline Características & \\
\hline Ambiente tectônico & $\begin{array}{l}\text { Margens convergente de placas (Nazca-Sul Americana) com componente obliquo pela } \\
\text { colisão do arco de Panamá-Choco com o NW da América do Sul. Ambiente } \\
\text { combinado de bacias do tipo "Back-Arc"e "Pull-Apart". }\end{array}$ \\
\hline Formação dos Magmas & $\begin{array}{l}\text { Origem mantélica. Formados pela subducção da placa de Nazca no território sul } \\
\text { Americano. }\end{array}$ \\
\hline Ascensäo dos Magmas & $\begin{array}{l}\text { Ascensão dos magmas a niveis crustais superiores, de forma rápida, controlado pelo } \\
\text { Sistema de Falhas de Cauca-Romeral. Originado pelo ambiente distencional da } \\
\text { bacias "PullmApart". } \\
\text { Crosta superior }\end{array}$ \\
\hline Colocação dos Magmas & Crosta superior. \\
\hline Tipo Magmatismo & Cálci-alcalino a toleitico. \\
\hline Encaixante & Andesito Dacito Pórfiro \\
\hline Idade do Stock de Marmato & $6,3 \pm 0,7 \mathrm{Ma}$ \\
\hline Sistema Hidrotermal & $\begin{array}{l}\text { Originado pelo resfriamento do andesito dacito do Stock de Marmato, com o Sistema } \\
\text { de Faihas de Romeral ativo. }\end{array}$ \\
\hline $\begin{array}{l}\text { Duração do sistema } \\
\text { hidrotermal }\end{array}$ & No intervalo entre $6,3 \pm 0,7 \mathrm{Ma}$ a $5,6 \pm 0,6 \mathrm{Ma}(700,000$ anos). \\
\hline Tipo de Fluidos & Mistura de fluidos magmáticos e meteóricos. \\
\hline Temperatura dos fluidos & 260 a $310^{\circ} \mathrm{C}$ \\
\hline Alteração hidrotermal & Ampla propilitizaçäo e restrita sericitização nos veios. \\
\hline PH dos fluidos & Intermediaria, 5-6. \\
\hline Controle da mineralizaçăo & $\begin{array}{l}\text { Estrutural, veios distencionais orientados NNW á E-W. Formados em ambiente } \\
\text { distencional. }\end{array}$ \\
\hline Estrutura & Preenchimento de espaços abertos, formação de bandas de pirita e esfalerita. \\
\hline Minério & Au-Ag. \\
\hline Minerais de Minério & $\begin{array}{l}\text { Pirita, esfalerita, galena, pirrotita, arsenopirita, calcopirita; mais raramente prata, } \\
\text { argentita, polybasite, oro, electrum ( } \mathrm{Au}-\mathrm{Ag} \text { ), teluretos, e sulfossais de } \mathrm{Bi}\end{array}$ \\
\hline Minerais de Ganga & Carbonato e quartzo. \\
\hline Paragênese & Fase1: Pirita; Fase 2: Esfalerita; Fase 3:Carbonato e Pirita2. Au nas três fases. \\
\hline $\begin{array}{l}\text { Circulação dos fluidos nas } \\
\text { fases. Setor de Echandia }\end{array}$ & $\begin{array}{l}\text { Circulação principal de fluidos hidrotermais meteóricos nas fases } 1 \text { e } 2 \text {. Na fase } 3 \text {, } \\
\text { hidrotermais magmáticos. }\end{array}$ \\
\hline $\begin{array}{l}\text { Circulação dos fluidos nas } \\
\text { fases. Setor de Marmato } \\
\text { Bajo }\end{array}$ & $\begin{array}{l}\text { Circulação de fluidos hidrotermais meteóricos e hidrotermais magmáticos nas fases } 1 \\
\text { e 2. Na fase } 3 \text {, hidrotermais magmáticos. }\end{array}$ \\
\hline Rochas fontes & $\begin{array}{l}\text { Participação principal dos andesitos dacitos pórfiros, subordinada dos xistos do } \\
\text { Complexo Arquía (xisto grafitoso). }\end{array}$ \\
\hline Anomalia geofísica & $\begin{array}{l}\text { Susceptibilidade magnética negativa, já que nos veios a magnetita é substituida por } \\
\text { pirita. }\end{array}$ \\
\hline Geoquimica & Anomalias de $\mathrm{Cu}, \mathrm{Pb}, \mathrm{Zn}, \mathrm{As}, \mathrm{Te}, \mathrm{Bi}$. \\
\hline CLASSIFICAÇÁO & DEPOSITO EPITERMAL Au-Ag, DE BAIXA SULFURAÇÃO (ADULARIA-SERICITA) \\
\hline
\end{tabular}




\section{REFERÊNCIAS BIBLIOGRÁFICAS}

ALVAREZ A. J. 1983. Geologia de la Cordillera Central y el Occidente Colombiano y Petroquimica de los Intrusivos Granitoides Mesocenozoicos. Boletín Geológico, Ingeominas, 26(2):1-175.

ALVAREZ A. e ARIAS A. 1970. Geología del Area de Marmato. Informe, Ingeominas.

ALVAREZ J. F. 1989. Geología, mineralogía y aspectos genéticos de los niveles La Waconda y Torre II, vereda Echandía, municipio de Marmato, departamento de Caldas. Proyecto de Grado, Universidad EAFIT, 130p.

ASPDEN J. A., MCCOURT W. J., BROOK M. 1987. Geometrical control of subduction related magmatism: the Mesozoic Cenozoic plutonic history of Western Colombia. Journal of the Geological Society, London, 144:893-905.

BEDOYA O. G. 1998. Geology, hidrothermal alteration, paragenetic sequence and fluid inclusion analysis of La Maruja Level, Marmato District, Caldas Department, Colombia. Thesis of Master of Science, Colorado State University, Fort Collins Colorado, EU, 165p.

BOTERO R. e ZULUAGA M. 1980. Geoquímica y Estructura de los Depósitos de Oro de Marmato. Tésis, Universidad Nacional de Colombia.

BUENAVENTURA J. A. 1997. Mineralización auro-argentifera en la zona de Echandía (Marmato Caldas). Informe final, Grancolombia Resources Ltda, 32p.

CADAVID A. e ESCOBAR C. M. 1991. Geología mineralogía y aspectos genéticos de la mina la Maruja, Distrito Minero de Marmato, Departamento de Caldas, Colombia. Trabajo de Grado, Universidad EAFIT, 393p. 
CALLE B. 1984. Mapa Geológico Preliminar, Plancha 186, Riosucio, Escala: 1:100.000. Mapa, Ingeominas.

CALLE B., GONZÁLEZ H. 1982. Geología y Geoquímica de la plancha 186 (Riosucio), Caldas. Informe, Ingeominas.

CALLE B., TOUSSAINT J. F., RESTREPO J. J., LINARES E. 1980. Edades K/Ar de los plutones de la parte septentrional de la Cordillera Occidental de Colombia. Geologia Norandina, 2: 17-20.

COOPER M. et al. 1995. Basin Development and Tectonic History of the llanos Basin, Eastern Cordillera, and Middle Magdalena Valley, Colombia. AAPG Bull., 79: 1421-1443.

CORBETT J, e LEACH T. 1998. South Pacific Rim Gold-Copper Systems: Struture, Alteration, and Mineralization. Special publication, Society of Economic Geologist, 6. $237 p$.

CUELLAR J. e MORA B. 1982. Paragéneisis del Yacimiento de las Minas Nacionales de Marmato. Proyecto de Grado, Universidad Nacional de Colombia.

CHAMORRO M. 1984. Prospección Geoquímica en Suelos en los alrededores de la Quebrada Chirapotó al sur del Departamento de Antioquia. Proyecto de grado, Universidad Nacional de Colombia,105p.

CHIARADIA M. e FONTBOTE L. 2001a. Metal Sources in Jurassic to Miocene Ore Deposits os Equador. Actas III, South American Symposium on Isotope Geology, CDR.

CHIARADIA M. e FONTBOTE L. 2001b. Radiogeneic Lead Signatures in Au-Rich Volcanic-Hosted Massive Sulfide Ores and Associates Volcanic Rocks of the 
Early Tertiary Macuchi Island Arc (Western Cordillera of Equador). Economic Geology, 96(6): 1361-1378.

DARDENNE M. A. e SHOBBENHAUS. C. 2001. Metalogênese do Brasil, Universidade de Brasilia. 392 p.

DePAOLO D. J. e WASSERBURG G. J. 1976. Nd isotopic variations and petrogenetic models. Geophysical Research Letters, 3(5): 249-252.

DePAOLO D. 1988. Neodynium Isotope Geochemistry, An Introduction. Springer Verlag, $187 \mathrm{p}$.

DICKIN A. 1995. Radiogenic Isotope Geology. Cambridge University Press, 490p.

DOE B. 1970. Lead Isotopes. Springer Verlag, 137p.

DUQUE-CARO H. 1990. The Choco Block in the northwestern corner of South America: Strutural, tectonostratigraphic, and paleogeographic implications. Journal of South America Earth Sciences, 3(1): 71-84.

EGO F. e SEBRIER M. 1995. Is the Cauca-Patia and Romeral fault system left - or right-lateral?. Geophysical Research Letter, 22: 33-36.

ETAYO F. et al. 1986. Mapa de Terrenos geológicos de Colombia. Publicación Geológica Especial, Ingeominas, 14. 235 p.

FAURE G. 1986. Principles of Isotope Geology. John Wesley and Sons, 589p.

FAURE G. e POWELL J. 1972. Strontium Isotope Geology. Springer Verlang, Berlin, $196 p$. 
GIGGENBACH W. 1992. Magma Degassing and Mineral Deposition in Hydrothermal Systems along Convergent Plate Boundaries. Economic Geology 87:1927-1944.

GOMEZ L. e RODRIGUEZ L. 1988. Ocurrencias Auriferas en un área aledaña a Marmato. Proyecto de Grado, Universidad Nacional de Colombia.

GONZÁLEZ H. 1976. Geología del Cuadrángulo J-8 (Sonsón). Informe, Ingeominas.

GONZÁLEZ H. 1980. Geología de las planchas 167, Sonsón y 187 Salamina. Boletín Geológico, Ingeominas, 23(1): 1-174.

GONZÁLEZ H. e CALLE, B. 1982. Geología y Geoquímica de la plancha 186 (Riosucio), Caldas. Informe, Ingeominas.

GONZÁLEZ H. e MAYA M. 1995. Unidades Litodémicas de la Cordillera Central de Colombia. Boletin Geológico, Ingeominas, 35(2-3): 43-57.

GROSSE E. 1926. Estudio Geológico del Terciario Carbonífero de Antioquia. Dietrich Reimer.

GULSON B. L. 1986. Lead Isotopes in mineral exploration. Elsevier, 245 p.

HEALD P., FOLEY N., HAYBA D. 1987. Comparative Anatomy of Volcanic-Hosted Epithermal Deposits: Acid-Sulfate and Adularia-Sericite Types. Economic Geology 82(1): 1-26.

HEDENQUIST J. e GULSON B. 1992. Intrusive and basement rock sources of lead in hydrothermal systems of Taupo Volcanic Zone, New Zeland. Geochimica et Cosmochimica Acta 56: 2821-2829. 
HEDENQUIST J. E LOWENSTERN J. 1994. The role of magmas in the formation of hydrothermal ore deposits. Nature 30: 519-527.

HEDENQUIST J., MATSUHISA Y., IZAWA E., WHITE N., GIGGENBACH W., AOKI M. 1994. Geology, Geochemistry, and Origin of High Slfidation Cu-Au mineralization in the Nansatsu District, Japan. Economic Geology 89(1): 1-30.

HUTHCHINSON C.S. 1983. Economic Deposits and their Tectonic Setting. Macmillan Publishers, Hong Kong.

INGEOMINAS. 1988. Memoria Explicativa del Mapa Geológico de Colombia, Escala 1: 1.500.000. Memoria, Ingeominas, $71 \mathrm{p}$.

INGEOMINAS. 1993. Memoria Explicativa del Mapa Geológico del Departamento de Caldas, Escala 1: 250.000. Memoria, Ingeominas, 62 p.

INGEOMINAS. 1995. Minerales Estratégicos para el desarrollo de Colombia. Ingeominas, $340 \mathrm{p}$.

INGEOMINAS. 1999. Prospección Geológica Regional de la Zona Cauca-Romeral-Patía y Rochas asociadas. Informe, Ingeominas.

JAMES D. E. E MURCIA A. 1984. Crustal contamination in northern Andean volcanics. Journal of Geological Society, London, 141: 823-860.

JARAMILLO J. M. 1978. determinacion de las edades de algunas rocas de la Cordillera Central de Colombia por el método de huellas de fision. In: /I Congreso Colombiano de Geologia, Bogotá, Resumenes.

KEATS W. 1976. The Roraima Formation in Guyana: a revised stratigraphy and proposed environment of diposition. // Cong. Lat. de Geol, Caracas: 901-940. 
KEIO S., TASSINARI C., KOJI K., PETRONILHO L. 1995. O Método Geocronológico Sm-Nd no IGC/USP e suas Aplicações. Anais Academia Brasileira de Ciência, 67 (3).

KERR A., ASPDEN J., TARNEY J., PILATASIG L. 2002. The nature and provenance of accreted oceanic terranes in western Equador: geochemical and tectonic constrains. Jornal of the Geological Society, London. 159: 577-594.

LITHERLAND J. M. e ASPDEN J. A. 1992. Terrane-boundary reactivation: a control on the evolution of the Northern Andes. Journal of South American Earth Sciences, 5: $71-76$.

LITHERLAND M., ASPDEN J. A., JEMIELITA R. A. 1994. The metamorphic belts of Ecuador: British Geological Survey Overseas Memoir 11, 112p.

LOPEZ-RENDON J. E. 1991. Geología, mineralogía y aspectos genéticos de las minas La Maria y Aguaceral, distrito minero de Marmato, Departamento de Caldas. Revista Universidad EAFIT, 8: 93-107.

LOPEZ-RENDON J. E. e BEDOYA O. G. 1989. Geología, mineralogía e aspectos genéticos de las minas La Palma y La Negra, distrito minero de Marmato. Memorias, $V$ Congreso Colombiano de Geología, Bucaramanga, Tomo I: 561 588.

LOZANO H. e PULIDO O. 1986. Situación actual del oro y la plata en Colombia. Boletín Geológico, Ingeominas, 23(3).

MacDONALD W. 1980. Anomalous paleomagnetic directions in late Tertiary andesitic intrusions of the Cauca Depression, Colombian Andes. Tectonophisics, 68: 339348. 
MACFATLANE A. W. 1995. Linear arrays in Andean Pb Isotope Data and the Depth of Mixing. The Geologycal Society of America, Annual Meeting, Abstracts, 27(6).

MARRINER G. F. e MILLWARD D. 1984. The petrology and geochemistry of Cretaceous to recent volcanism in Colombia: the magmatic history of an accretionary plate margin. Journal of the Geological Society, London, 141:473486.

MARTINEZ R., CORDOBA L. 1989. Estudio Geológico y Geoquímico de las Manifestaciones Auríferas Filonianas al Sur y Oeste de Marmato. Proyecto de Grado, Universidad Nacional de Colombia.

MAYA M. 1992. Catalogo de Dataciones Isotópicas de Colombia. Boletín Geológico, Ingeominas, 32(1-3): 127-187.

MEDINA H. E. 1989. Geología mineralogía y aspectos genéticos de la mina la Villonza, Distrito Minero de Marmato, Departamento de Caldas, Colombia. Trabajo de Grado, Universidad EAFIT, 207p.

MITCHELL A.H. e GARSON M. 1981. Mineral Deposits and Global Tectonic Settings. London, Academic Press Geology Series.

MOLINA C. A. 1991. Geología mineralogía y aspectos genéticos de la mina Dorotea, Distrito Minero de Marmato, Departamento de Caldas, Colombia. Trabajo de Grado, Universidad EAFIT, 237p.

MONSALVE J. J. 1989. Geología, mineralogía, y aspectos genéticos de la mina Echandia, Distrito Minero de Marmato, Departamento de Caldas, Niveles la Maria y Aguaceral. Proyecto de Grado, Universidad EAFIT, 182p. 
ORDOÑEZ C. O. 2001. Caracterização isotópica Rb-Sr e Sm-Nd dos principais eventos magmáticos nos Andes Colombianos. Tese de Doutorado, Instituto de Geociências, Universidade de Brasilia, Brasilia, 197p.

ORTIZ F. 1999. Mineralizaciones metálicas asociadas a la zona tectónica CaucaRomeral: Zona norte (Marmato-Chirapotó). Boletín de Ciencias de la Tierra, 13: 98-110.

ORTIZ F., ZAMUDIO M., ZAPATA H. 1987. Estudio Geoquimico de las rocas metamorficas en los alrededores de la quebrada Chirapoto (Sur de Antioquia). Memorias, Seminario Gerardo Botero Arango, Geología de la Cordillera Central de Colombia.

PARIS G. e ROMERO J. A. 1994. Fallas Activas en Colombia. Boletín Geológico, Ingeominas, 34(2-3): 6-25 p., Ingeominas.

PRIEM H., et al. 1982. Geochronology of the precambrian in the Amazonas region of southeastern Colombia (Western Guiana Shield). Geol. Mijnbouw, 61(3): 229-242.

RAMOS V. A. 1999. Plate Tectonic setting of the Andean Cordillera. Episodes, 23(3): 183-190.

RESTREPO C. A. 1989. Geología mineralogia, alteración hidrotermal y génesis del depósito de oro "Mina la Mona", Municipio de Marmato, Departamento de Caldas, Colombia. Trabajo de Grado, Universidad EAFIT, 235p.

RESTREPO J. e TOUSSAINT J. 1974. Obducción Cretácica en el occidente Colombiano (Informe preliminar). Publicación Geológica Especial, Universidad Nacional, Medellin, 3. 
RESTREPO J. e TOUSSAINT J. 1975. Edades Radiométricas en algunas rocas de Antioquia. Publicaciones Especiales, Facultad de Minas de Medellin, 6.

RESTREPO J. e TOUSSAINT J. 1982. Compilacion de las Edades Radiométricas de Colombia. Departamentos Andinos hasta 1982. Boletín de Ciencias de la Tierra, Universidad Nacional, Medellin, 7-8: 201-248.

RESTREPO J. e TOUSSAINT J. 1988. Terranes and continental accretion in the Colombian Andes. Episodes, 11: 189-193.

RESTREPO J., TOUSSAINT J., GONZÁLEZ H. 1981. Edades Miopliocénicas del Magmatismo asociado a la Formação Combia, Departamento de Antioquia y Caldas. Geología Norandina, 3.

RESTREPO J., TOUSSAINT J., GONZÁLEZ H., CORDANI H., KAWASHITA K., LINARES E., PARICA E. 1991. Precisiones geocronológicas sobre el occidente Colombiano. Simposio sobre magmatismo andino y su marco tectónico, Manizalez, Mem. 1:1-21.

RODRIGUEZ C. 1993. Overview of some Colombian gold deposits and their development potential. Mineral Deposita, 28: 47-57.

ROSSETTI P. e COLOMBO F. 1999. Adularia-sericite gold deposit of Marmato (Caldas, Colombia): field and petrographical data. Special Publication, Fractures, Fluids Flow and Mineralization, Geological Society of London, 155: 167-182.

RUBIANO M. 1986. Presencia de Mackinawita, Cubanita II y Melnicovita, en los depósitos de oro de Marmato. Geología Norandina, 10.

SAWKINS F. J. 1990. Metal Deposits in Relation to Plate Tectonic. Springer Verlag. 
SIERRA G., SILVA J., CORREA L. 2000. Stratigraphic base level fluctuations and sandstone petrographic characterization as an indicator of the evolution of the late Oligocene-Late Miocene Amaga Formation. Papers, Stratigraphy and Sedimentology Research Group, EAFIT University, 35p.

SILLITOE R., JARAMILLO L., DAMON P., SHAFIQULLAH M., ESCOVAR R. 1982. Setting, Characteristics, and Age of the Andean Porphyry Copper Belt in Colombia. Economic Geology, 77: 1837-1850.

SILLITOE R., JARAMILLO L. e HART S. 1984. Lead-isotope signatures of porphyry copper deposits in oceanic and continental settings, Colombian Andes. Geochimica et Cosmochimica Acta, 48: 2135-2142.

STACEY J. e KRAMERS J. 1975. Approximation of terrestrial lead isotope evolution by a two-stage model: Earth Planet. Sci. Letters, 26: 207-221.

STIPP B. M., SIGA J.O., SATO K., SPROESSER W. M. 1995. A Metodologia UrânioChumbo na Universidade de São Paulo. Princípios Metodológicos, Aplicações e Resultados Obtidos. Anais Academia Brasileira de Ciencia, 67 (2).

TABOAdA A., RIVERA L., FUENZALIDA A., CISTERNAS A., PHILIP H., BIJWAARD H., OLAYA J., RIVERA C. 2000. Geodynamics of the northern Andes: Subductions and intracontinental deformation (Colombia). Tectonics, 19: 787-813.

TASSINARI C. C. 1996. O Mapa Geocronológico do Craton Amazônico no Brasil: Revisão dos Dados Isotópicos. Tese de Livre Docência, Instituto de Geociências, Universidade de São Paulo, $139 \mathrm{p}$.

TASSINARI C. G. e MACAMBIRA M. J. 1999. Geochronological provinces of the Amazonian Craton. Episodes, 22(3): 174-182. 
TASSINARI C. C. G. 1999. Radiogenic isotopes in ore deposits: an overview. Actas, II South American Symposium on Isotope Geology, 574-577.

THOMAZ-FILHO A. e TORQUATO J. R. 1974. Método Radiométrico Potássio-Argônio, Procedimentos das análises no Centro de Pesquisas Geocronológicas da Universidade de São Paulo, São Paulo, 76p.

TORQUATO J. R. e KAWASHITA K. 1990. Radioatividade e princípios físicos da geocronologia. Revista de Geologia, Universidade Federal do Ceará, 3:101-121.

TORQUATO J. R. e KAWASHITA K. 1991. Geocronologia Nuclear, Métodos Geocronológicos: Técnicas de Medida Espectrógrafos e Espectrômetros. Revista de Geologia, Universidade Federal do Ceará, 4:91-126.

TORQUATO J. R. e KAWASHITA, K. 1992. Geocronologia Nuclear, o Método K/Ar. Revista de Geologia, Universidade Federal do Ceará, 5: 177-207.

TORQUATO J. R. e KAWASHITA K. 1994. Geocronologia Nuclear, o Método Rb/Sr. Revista de Geologia, Universidade Federal do Ceará, 7: 91-124.

TOUSSAINT J. 1993. Evolución Geológica de Colombia, Precámbrico y Paleozóico. Universidad Nacional de Colombia, 129p.

TOUSSAINT J. F. e RESTREPO J.J. 1976. Modelos orogénicos de tectónica de placas en los Andes Colombianos. Boletín Ciencias de la Tierra, 1.

TOUSSAINT J. F. e RESTREPO J. J. 1989. Acreciones sucesivas en Colombia: Un nuevo modelo de evolución geológica. $\vee$ Congreso Colombiano de Geología, Bucaramanga, Tomo I: 127-146. 
TOUSSAINT J. e RESTREPO J. 1991. El magmatismo en el marco de la evolución geotectónica de Colombia. Simposio sobre magmatismo andino y su marco tectónico, Manizalez, Mem. 1: 135-150.

U.S.G.S. 1986. Mineral Deposits Models. Bulletin 1693, U.S. Geological Survey.

VAN DER HAMMEN T. 1957. Climatic periodicity and evolution of South American Maestrichtian and tertiary floras. Boletin Geológico, Ingeominas, 5: 43p.

VAN DER HAMMEN T. 1960. Estratigrafía del Terciario y Maestrichtiano Continentales y Tectogénesis de los Andes Colombianos. Boletín Geológico, Ingeominas, 6:67128.

VINASCO C.J. 2001. A utilização da metodologia ${ }^{40} \mathrm{Ar}-{ }^{39} \mathrm{Ar}$ para o estudo de reativações tectônicas em zonas de cisalhamento. Paradigma: O Falhamento de Romeral nos Andes Centrais da Colômbia. São Paulo, 85 p. Dissertação (Mestrado) - Instituto de Geociências, Universidade de São Paulo.

VINASCO C. J., CORDANI U. G., VASCONCELOS, P. 2001. ${ }^{40} \mathrm{Ar} /{ }^{39} \mathrm{Ar}$ Dates in The Central Cordillera of Colombia: Evidence for an Upper Triassic Regional Tectonomagmatic Event. III South American Symposium on Isotope Geology, Chile, Actas-CDR.

ZAPATA M. I. e PELAEZ L. 1991. Geología mineralogía y aspectos genéticos de la mina el doscientos, Distrito Minero de Marmato, Departamento de Caldas, Colombia. Trabajo de Grado, Universidad EAFIT, 182p.

ZARTMAN R. E. e DOE B.R. 1981. Plumbotectonic-The Model. Tectonophysics, 75:135-162. 
APÊNDICE A.

EQUAÇÕES DA GEOCRONOLOGIA 


\section{APÊNDICE A1}

\section{A1a. Equação do decaimento radioativo}

O decaimento radiativo é expresso matematicamente como:

$$
\frac{\mathrm{dN}}{\mathrm{dt}}=-\lambda \mathrm{N}
$$

Resolvendo:

$$
\frac{d N}{d t}=-\lambda N \Rightarrow \frac{d N}{N}=-\lambda d t \Rightarrow \int \frac{d N}{N}=-\int \lambda d t \Rightarrow \ln N=-\lambda t+c
$$

Em $\mathrm{t}=0$, valor da constante $\mathrm{c}=$ No.

$$
\ln N=-\lambda t+\ln N o \Rightarrow \ln \frac{N}{N o}=-\lambda t \Rightarrow t=\frac{1}{\lambda} \ln \frac{N o}{N} \Rightarrow N(t)=N_{o e^{-\lambda t}}
$$

onde:

$$
\left.N(t)=N_{o e}^{-\lambda t} \text { (Equação do decaimento radioativo }\right)(1)
$$

$N(t)=$ Número de átomos radioativos não transmutados ou Pai

$\mathrm{No}=$ Número de átomos radioativos originais

$\lambda=$ Constante de decaimento

$t=$ tempo de decaimento

\section{Atb. Equação fundamental da Geocronologia (E.F.G)}

Resolvendo a equação (1):

como:

$$
t=\frac{1}{\lambda} \ln \frac{N_{0}}{N}
$$

Substituindo:

$$
\text { No }=N(t)+F(t)
$$

$$
\begin{gathered}
t=\frac{1}{\lambda} \ln \left(\frac{P(t)+F(t)}{P(t)}\right) \\
t=\frac{1}{\lambda} \ln \left(1+\frac{F(t)}{P(t)}\right)(E . F . G)(2)
\end{gathered}
$$

Em função de $F(t)$ e $P(t)$ :

onde:

$$
F(t)=P(t)\left(e^{\lambda t}-1\right)\langle E . F . G \text {, em função de } F(t) \text { e } P(t)(3)
$$

$F(t):=$ Número de átomos transmutados ou Filhos

$N(t)=P(t)=$ Número de átomos não transmutados ou Pai $\lambda=$ Constante de decaimento $t=$ tempo de decaimento 


\section{APENNDICE A2}

\section{A2. Equação da isócrona e Diagrama Isocrônico}

Da equação (1)

$$
\begin{gathered}
N(t)=N o e^{-\lambda t} \Rightarrow N(t)=\frac{N o}{e^{\lambda t}} \Rightarrow \text { Como, } N o=N(t)+F(t) \Rightarrow N(t)=\frac{N(t)+F(t)}{e^{\lambda t}} \\
F(t)=N(t)\left(e^{\lambda t}-1\right) \Rightarrow \text { Como, } F(t)=F(\text { hoje })-F(o) \Rightarrow F(\text { hoje })=F(o)+N(t)\left(e^{\lambda t}-1\right) \\
F(\text { hoje })=F(o)+P(t)\left(e^{\lambda t}-1\right) \text { Equação de uma reta }(4) .
\end{gathered}
$$

Onde:

$F($ hoje $)=$ Número de átomos radiogênicos ou Filhos hoje.

$F(o)=$ Número de átomos radiogênicos ou Filhos iniciais.

$\mathrm{P}(\mathrm{t})=\mathrm{N}(\mathrm{t})=$ Número de átomos radiativos residual ou $\mathrm{Pai}$.

$\lambda=$ Constante de decaimento radiativo.

$t=$ tempo de decaimento.

\section{Diagrama isocrônico}

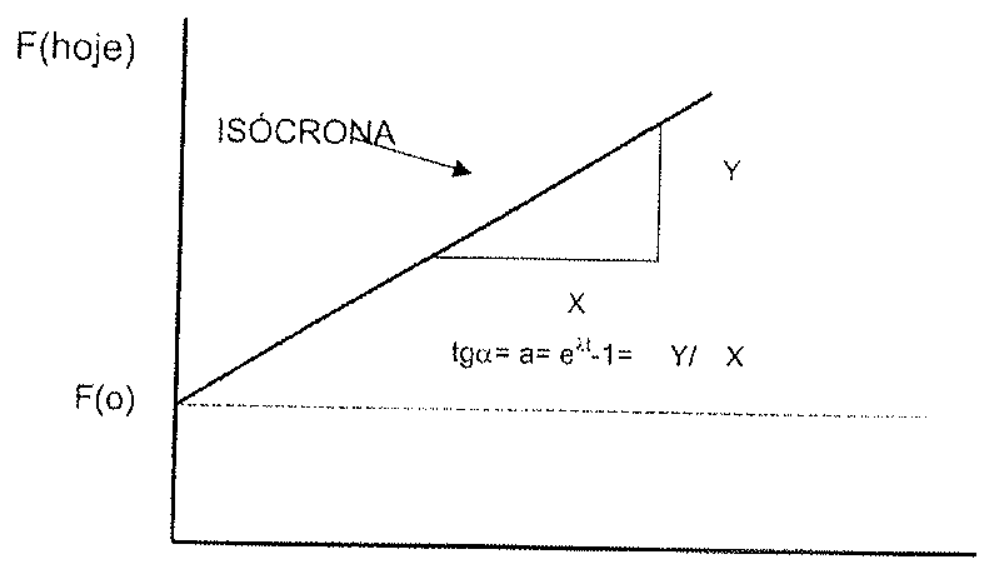

$P(t)$

A idade, será calculada com a equação:

$$
\mathrm{t}=\frac{\operatorname{tg} \alpha}{\lambda}
$$




\section{APÊNDICE A3.}

\section{A.3. Equações da Sistemática K-Ar}

Da equaçăo fundamental da Geocronologia (2):

A equação para $0^{40} \mathrm{~K}$ é:

$$
t=\frac{1}{\lambda} \ln \left(1+\frac{F(t)}{P(t)}\right)
$$

Onde:

$$
\mathrm{t}=\frac{1}{\lambda \beta^{-}+\lambda \mathrm{e}} \ln \left(1+\frac{{ }^{40} \mathrm{Ar}+{ }^{40} \mathrm{Ca}}{{ }^{40} \mathrm{~K}}\right)
$$

$\lambda \mathrm{e}=$ Decaimento do ${ }^{40} \mathrm{~K}$ ao ${ }^{40} \mathrm{Ar}\left(0.581 \times 10^{-10}\right.$ anos $)$

$\lambda \beta=$ Decaimento do ${ }^{40} \mathrm{~K}$ ao ${ }^{40} \mathrm{Ca}\left(4.962 \times 10^{-10}\right.$ anos $\left.^{-}\right)$

$\lambda=\lambda \mathrm{e}+\lambda \beta\left(5.543 \times 10^{-10} \mathrm{anos}^{-}\right)$

Como:

Substituindo

$$
\frac{{ }^{40} \mathrm{Ca}}{\lambda \beta^{-}}=\frac{{ }^{40} \mathrm{Ar}}{\lambda \mathrm{e}} \rightarrow{ }^{40} \mathrm{Ca}={ }^{40} \mathrm{Ar} \frac{\lambda \beta}{\lambda \mathrm{e}}
$$

$$
\mathrm{t}=\frac{1}{\lambda} \ln \left(1+\frac{{ }^{40} \mathrm{Ar}+{ }^{40} \mathrm{Ar} \frac{\lambda \beta}{\lambda \mathrm{e}}}{{ }^{40} \mathrm{~K}}\right) \rightarrow \mathrm{t}=\frac{1}{\lambda} \ln \left(1+\frac{\frac{{ }^{40} \mathrm{Ar} \lambda \mathrm{e}+{ }^{40} \mathrm{Ar} \lambda \beta}{\lambda \mathrm{e}}}{{ }^{40} \mathrm{~K}}\right)
$$

$$
\mathrm{t}=\frac{1}{\lambda} \ln \left[1+\frac{\lambda \mathrm{e}+\lambda \beta}{\lambda \mathrm{e}} \times \frac{{ }^{40} \mathrm{Ar}}{{ }^{40} \mathrm{~K}}\right] \rightarrow \mathrm{t}=\frac{1}{\lambda} \ln \left[\frac{{ }^{40} \mathrm{Ar}}{{ }^{40} \mathrm{~K}}\left(\frac{\lambda}{\lambda \mathrm{e}}\right)+1\right]
$$

Substituindo os valores de $\lambda$ e e $\lambda \beta$ :

$$
t=1.804 \times 10^{9} \ln \left(1+9.54 \frac{{ }^{40} \mathrm{Ar}}{{ }^{40} \mathrm{~K}}\right)(\text { equação }(5))
$$

Onde:

$t=$ tempo requerido para a formação do ${ }^{40} \mathrm{Ar}$, pelo decaimento do ${ }^{40} \mathrm{~K}$, de acordo com as constantes de decaimento do ${ }^{40} \mathrm{Ar}$ e do ${ }^{40} \mathrm{Ca}$. 


\section{APÊNDICE A4}

\section{A.4.1. Equação para o cálculo da razão ${ }^{143} \mathrm{Nd} /{ }^{144} \mathrm{Nd}$ do "CHUR" para qualquer tempo}

Da equação fundamental da Geocronologia (3):

$$
F(t)=P(t)\left(e^{\lambda t}-1\right) \rightarrow F_{\text {Radiogenico }}^{\text {temp }}=P(\text { hoje })\left(e^{\lambda t}-1\right)
$$

Para o Sm e Nd no "CHUR":

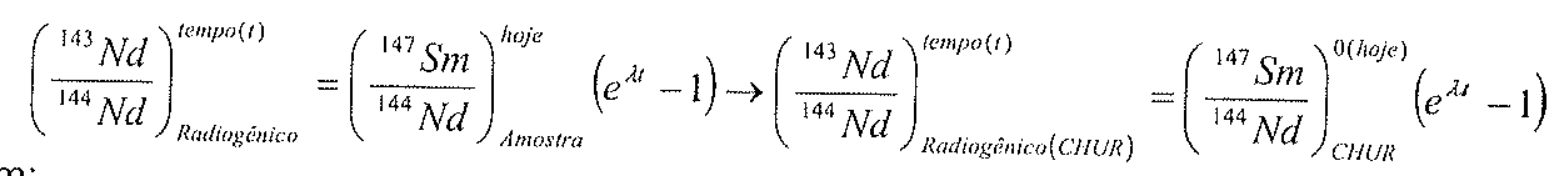

Sem:

$$
\begin{aligned}
& I_{\text {CHUR }}^{t}=\frac{{ }^{143} \mathrm{Nd}}{{ }^{144} \mathrm{Nd}} \text { do CHUR a qualquer tempo } \\
& I_{\mathrm{CHUR}}^{0}=\frac{{ }^{143} \mathrm{Nd}}{{ }^{144} \mathrm{Nd}} \text { do CHUR no tempo atual }(0.512638) \\
& I_{\text {CHUR }}^{0.1,}={ }^{143} \mathrm{Nd} \\
& \left(\frac{{ }^{147} \mathrm{Sm}}{{ }^{144} \mathrm{Nd}}\right)_{\text {CHUR }}^{0}=\frac{{ }^{147} \mathrm{Sm}}{{ }^{144} \mathrm{Nd}} \text { presen te do CHUR }(0.1967)
\end{aligned}
$$

logo para qualquer tempo:

$$
I_{\text {CHUR }}^{t}=I_{\text {CHUR }}^{0}-I_{\text {CHUR }}^{0 \sim T} \rightarrow I_{\text {CHUR }}^{t}=I_{\text {CHUR }}^{0}-\left(\frac{{ }^{147} \mathrm{Sm}}{{ }^{144} \mathrm{Nd}}\right)_{\text {CHUR }}^{0}\left(e^{\text {At }}-1\right) \text { equação(6) }
$$

\section{A.4.2. Equação do parâmetro $\varepsilon N d$}

Onde:

$$
\begin{aligned}
& \mathrm{Nd}_{\mathrm{CHUR}}^{\mathrm{t}}=\left[\frac{\left({ }^{143} \mathrm{Nd} / /^{144} \mathrm{Nd}\right)_{1}}{\mathrm{I}_{\text {CHUR }}^{t}}-1\right] \times 10^{4} \text { equação(7) } \\
& \varepsilon \mathrm{Nd}_{\text {CHUR }}^{0}=\left[\frac{\left({ }^{143} \mathrm{Nd} / /^{144} \mathrm{Nd}\right)_{\text {medido }}}{1_{\text {CHUR }}^{0}}-1\right] \times 10^{4}
\end{aligned}
$$

$\varepsilon \mathrm{Nd}^{\mathrm{t}}=$ Valor para um tempo $(\mathrm{t})$.

$\varepsilon \mathrm{Nd}^{0}=$ Valor para hoje.

$\left({ }^{143} \mathrm{Nd} /{ }^{144} \mathrm{Nd}\right)_{\mathrm{t}}=$ Razão no tempo $(\mathrm{t})$. 


\section{A.4.3. Equação da Idade Modelo} Na idade modelo o valor da razão ${ }^{143} \mathrm{Nd} /{ }^{144} \mathrm{Nd}$ do "CHUR" e da amostra (R), no
tempo t, são iguais, logo:

Da equação (6)

$$
I_{\text {CHUR }}^{t}=\left(\frac{143 \mathrm{Nd}}{{ }^{144} \mathrm{Nd}}\right)_{R}^{\prime}
$$

$$
\left(\frac{{ }^{143} \mathrm{Nd}}{{ }^{144} \mathrm{Nd}}\right)_{R}^{\prime}=\left(\frac{{ }^{143} \mathrm{Nd}}{{ }^{144} \mathrm{Nd}}\right)_{R}^{\text {medido }}-\left(\frac{{ }^{147} \mathrm{Sm}}{{ }^{144} \mathrm{Nd}}\right)_{R}^{\text {medido }}\left(\mathrm{e}^{\lambda 1}-1\right)
$$

Da equação (6):

$$
\mathrm{I}_{\text {CHUR }}^{0}-\left(\frac{{ }^{147} \mathrm{Sm}}{{ }^{144} \mathrm{Nd}}\right)^{0}\left(\mathrm{e}^{\lambda t}-1\right)=\left(\frac{{ }^{143} \mathrm{Nd}}{{ }^{144} \mathrm{Nd}}\right)_{\mathrm{R}}^{\mathrm{m}}-\left(\frac{{ }^{147} \mathrm{Sm}}{{ }^{144} \mathrm{Nd}}\right)\left(\mathrm{e}^{\lambda t}-1\right)
$$

$\log 0$

$$
\left(e^{\lambda t}-1\right)=\frac{\left(\frac{{ }^{143} \mathrm{Nd}}{{ }^{144} \mathrm{Nd}}\right)_{R}^{m}-I_{\mathrm{CHUR}}^{0}}{\left(\frac{{ }^{147} \mathrm{Sm}}{{ }^{144} \mathrm{Nd}}\right)_{R}^{m}-\left(\frac{{ }^{147} \mathrm{Sm}}{{ }^{144} \mathrm{Nd}}\right)_{\text {CHUR }}^{0}}
$$

Resolvendo:

$$
\mathrm{t}=\frac{1}{\lambda} \ln \left[\frac{\left(\frac{{ }^{143} \mathrm{Nd}}{{ }^{144} \mathrm{Nd}}\right)_{R}^{\mathrm{m}}-\mathrm{I}_{\mathrm{CHUR}}^{\circ}}{\left(\frac{{ }^{147} \mathrm{Sm}}{{ }^{144} \mathrm{Nd}}\right)_{R}^{\mathrm{m}}-\left(\frac{{ }^{147} \mathrm{Sm}}{{ }^{144} \mathrm{Nd}}\right)_{\text {CHUR }}^{o}}+1\right](\text { equação(8)) }
$$

\section{Onde:}

$\mathrm{t}=$ Idade modelo

$\mathrm{R}=$ Rocha

$\mathrm{m}=$ medido(hoje)

$0=$ medido (hoje) para o "CHUR" 


\section{A.4.4. Alguns valores}

Razão atual para alguns meteoritos "CHUR":

$\frac{{ }^{147} \mathrm{Sm}}{{ }^{144} \mathrm{Nd}}=0.1967$

Razão atual do manto empobrecido:

$\frac{{ }^{147} \mathrm{Sm}}{{ }^{144} \mathrm{Nd}}=0.222$

Razão atual para o "CHUR":

$\frac{{ }^{143} \mathrm{Nd}}{{ }^{144} \mathrm{Nd}}=0.512638$

Razão atual do manto empobrecido:

$\frac{{ }^{143} \mathrm{Nd}}{{ }^{144} \mathrm{Nd}}=0.513114$ 


\section{APÊNDICE B. \\ DESCRIÇÃO DE LAMINAS E POLIDOS}




\section{Localização}

AMOSTRA FHD2

Mina Plata Fría

\section{Descrição Macroscópica}

Veio fino (1 a $2 \mathrm{~cm}$ ) de sulfetos dentro de encaixante com silicificação e sericitização.

\section{Composição}

\section{Descrição Microscópica}

+++ Pirita (Py), ++ Esfalerita (Esf), + Galena (Gal), + Arsenopirita (Asp), + Calcopirita (Cpy), - Argentita (Ag). + Ganga (Quartzo (Qz))

\section{Textura e Minerais}

Sulfetos principalmente pirita, até $2 \mathrm{~mm}$, fraturados e irregulares com abundantes microcristais de Cpy, Esf, Gal e quartzo. Freqüentes texturas de substituição: Py, Cpy, Esf, Qz substituindo a Galena; Esf substituindo a Py e Asp; possível Asp substituindo Py. Comum textura de intercrescimento de Cpy e Esf, possível Asp intercrescida em Py. Calcopirita como microglóbulos em fraturas em clivagems de pirita e esfalerita.

Pirita: Subédrica apresenta microcristais de galena e esfalerita e microglóbulos de calcopirita em planos de clivagem.

Esfalerita: Anédrica apresenta microcristais de galena, pirita e microglóbulos de calcopirita ("calcopirita disease").

Galena: Euédrica a subédrica, intercrescimento de argentita, planos de clivagem deformados e fraturas preenchidas de mineral derivado de galena.

Arsenopirita: Euédrica a subédrica, pode estar substituída por esfalerita.

Calcopirita: Anédrica, intercrescida com esfalerita.

Ganga: Quartzo euédrico em fraturas e substituindo sulfetos.

Paragênese

Galena Pirita-Arsenopirita Esfalerita-Calcopirita Quartzo

Muito abundante $(+++)$; Abundante $(++)$; Comum (+); Presente (o); Traço (-)

\section{Localização}

AMOSTRA FHD7

Mina La Palma.

Descrição Macroscópica

Veio de sulfetos (1 a $2 \mathrm{~cm}$ ) dentro de encaixante silicificada.

\section{Composição}

\section{Descrição Microscópica}

+++ Pirita (Py), ++ Esfalerita (Esf), o Galena (Gal), o Calcopirita (Cpy), - Ouro. ++ Ganga (Quartzo (Qz)) 


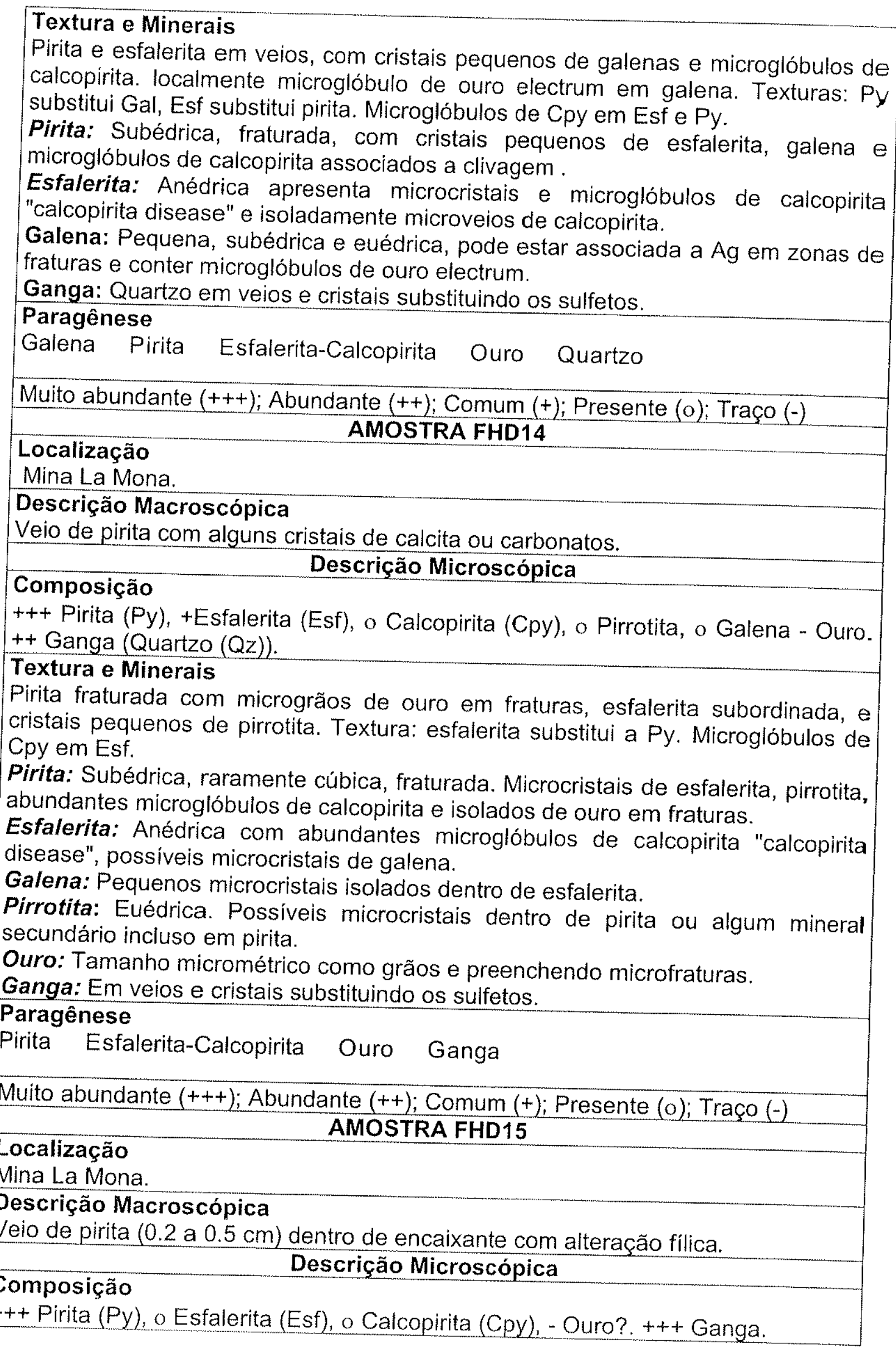




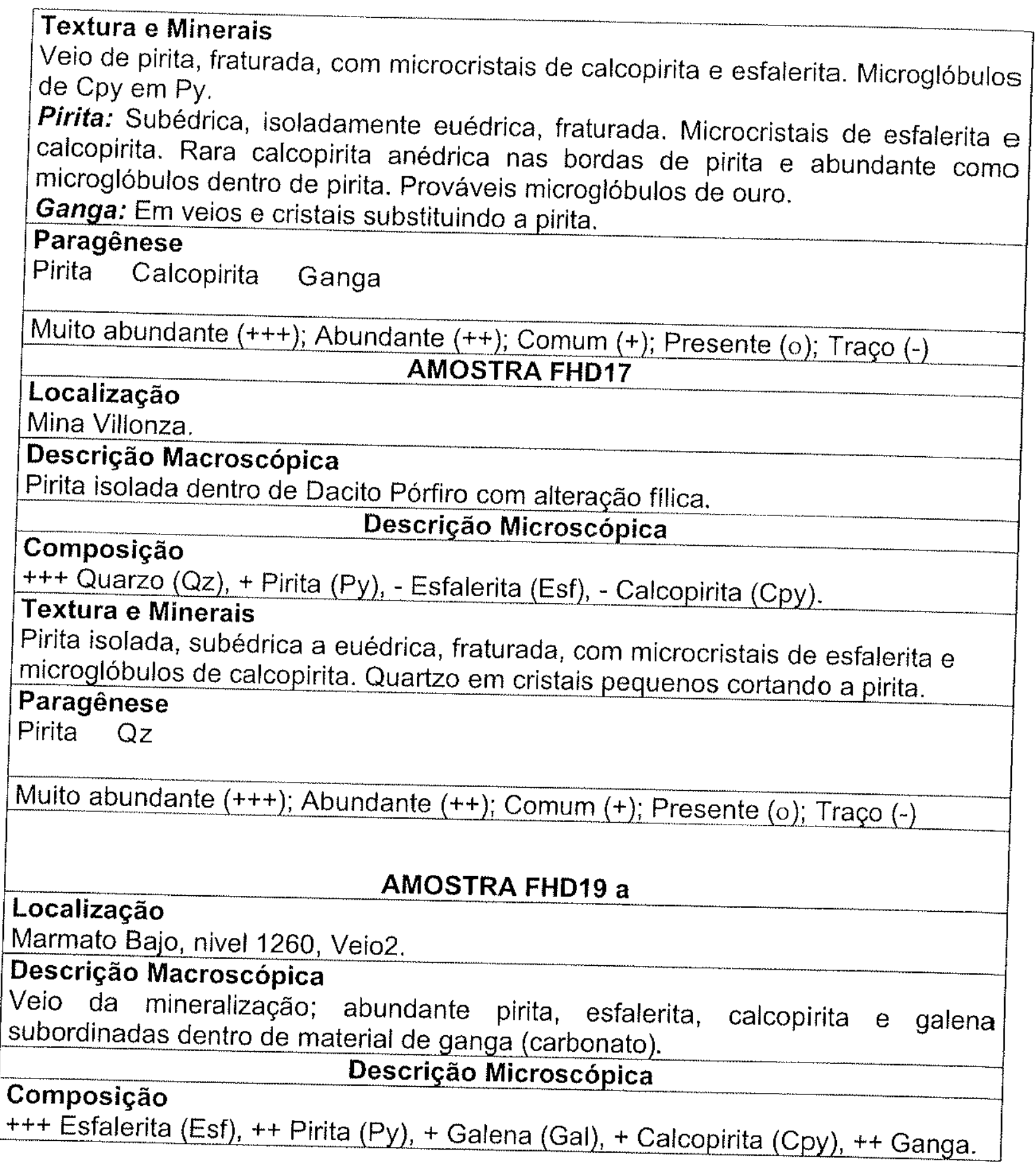




\begin{abstract}
Textura e Minerais
Esfalerita dentro de material de ganga; pirita, calcopirita e galena subordinadas.

Galena substituida por Py, Cpy e Esf; pirita substituida por galena, esfalerita, calcopirita. Textura de intercrescimento de Cpy e Esf, microglóbulos de Cpy.

Esfalerita: Granulação grossa $<4 \mathrm{~mm}$, subédrica, fraturada. Contem cristais de pirita e galena até $1 \mathrm{~mm}$. Apresenta abundantes microglóbulos de calcopirita, às vezes microveios de calcopirita deformada, fraturas geralmente sem preenchimento mas podem conter argilominerais e comumente pequenos cristais de carbonato.
\end{abstract}

Pirita: Apresenta-se como cristais dentro da esfalerita ou com habito cúbico dentro de ganga, contém pequenos cristais de esfalerita e microcristais de calcopirita.

Galena: Apresenta-se dentro de esfalerita, cristais subédricos.

Calcopirita: Como cristais anédricos intercrescidos com esfalerita e como microglóbulos dentro de esfalerita.

Ganga: Carbonatos, aparecem como cristais pequenos dentro de esfalerita e aparentemente podem estar em fraturas

\title{
Paragênese
}

Galena $\rightarrow$ Pirita $\rightarrow$ Galena (ou Pirita $\rightarrow$ Galena $\rightarrow$ Pirita) Esfalerita-Calcopirita $\rightarrow$ Carbonatos $\rightarrow$ Argilominerais

Muito abundante $(+++)$; Abundante $(++)$; Comum (+); Presente $(0)$; Traço $(-)$

Localização

AMOSTRA FHD19 b

Marmato Bajo, nivel 1260, Veio2.

Descrição Macroscópica

Veio da mineralização; abundante pirita, esfalerita, calcopirita e galena subordinadas dentro de material de ganga (carbonato).

\section{Composição}

Descrição Microscópica

+++ Pirita (Py), ++ Esfalerita (Esf), + Calcopirita (Cpy), - Pirrotita (Po), -Galena (Gal), ++ Ganga.

\section{Textura e Minerais}

Cristais de esfalerita e pirita fraturados inclusos dentro de material de ganga, com microcristais de calcopirita e galena. Texturas: esfalerita substitui a pirita, intercrescimento de calcopirita e esfalerita. Possivel Py2 substituindo a Py1.

Pirita: Euédrica a subédrica, com abundantes microglóbulos de calcopirita, isolados microcristais de pirrotita? e de galena. Cristal de pirita cúbica (Py2)
substituíndo a Py1.

Esfalerita: Anédrica, fraturada; intercrescida com calcopirita e com abundantes microglóbulos de calcopirita.

Calcopirita: Anédrica associada a esfalerita e preenchendo espaços inter granulares de pirita.

Ganga: Carbonatos preenchendo fraturas e como cristais de menor tamanho dentro de sulfetos. 


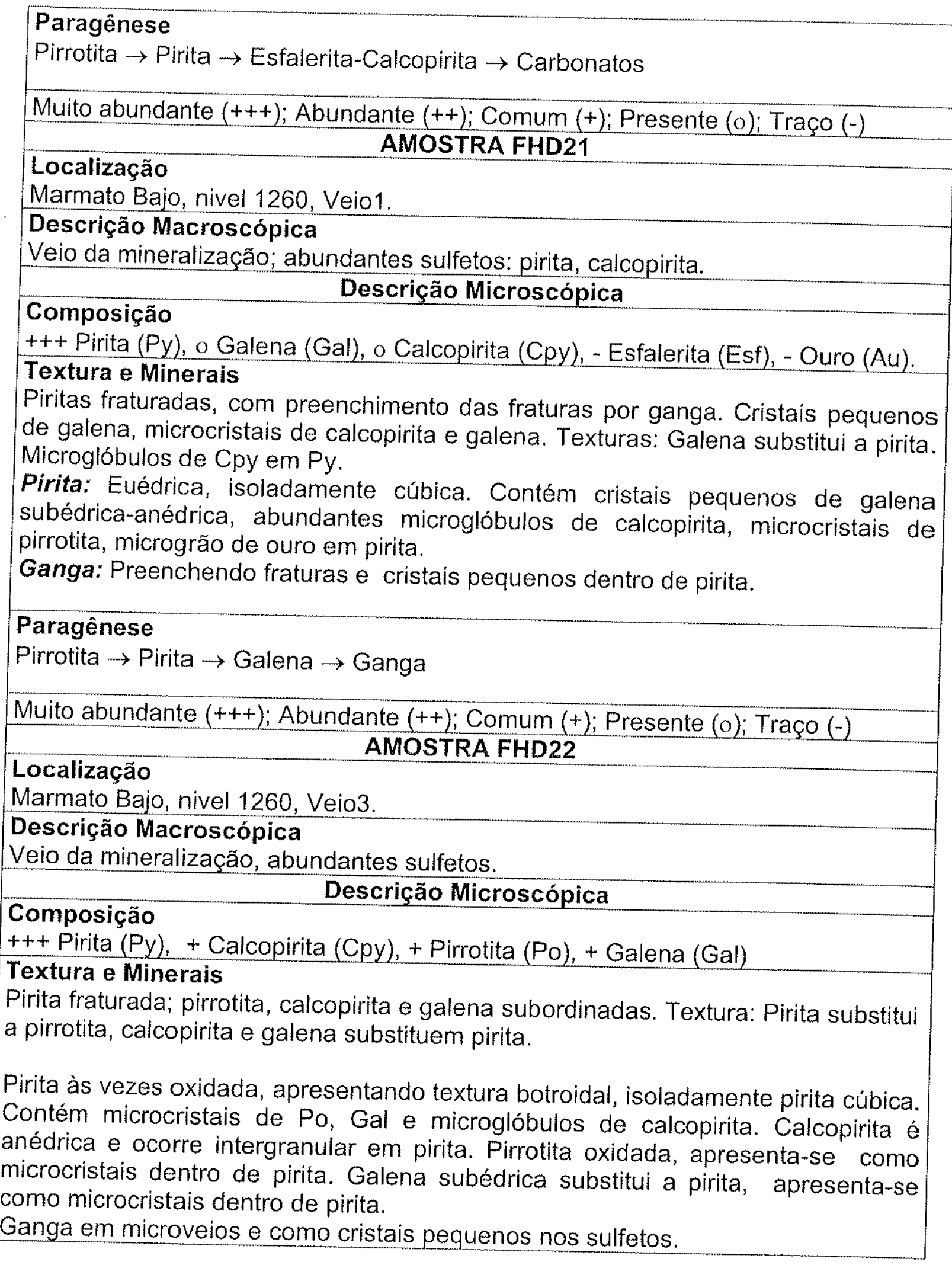




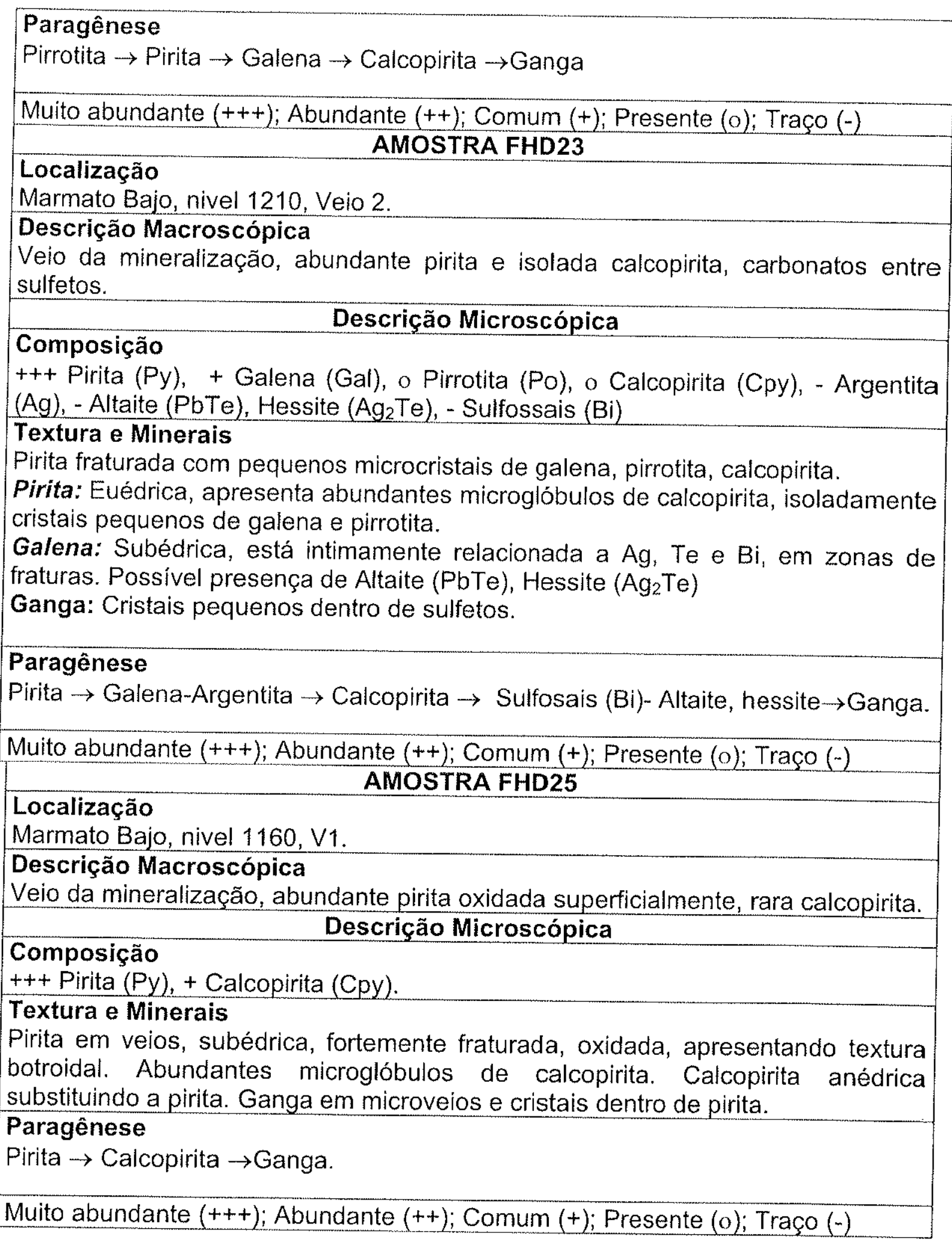




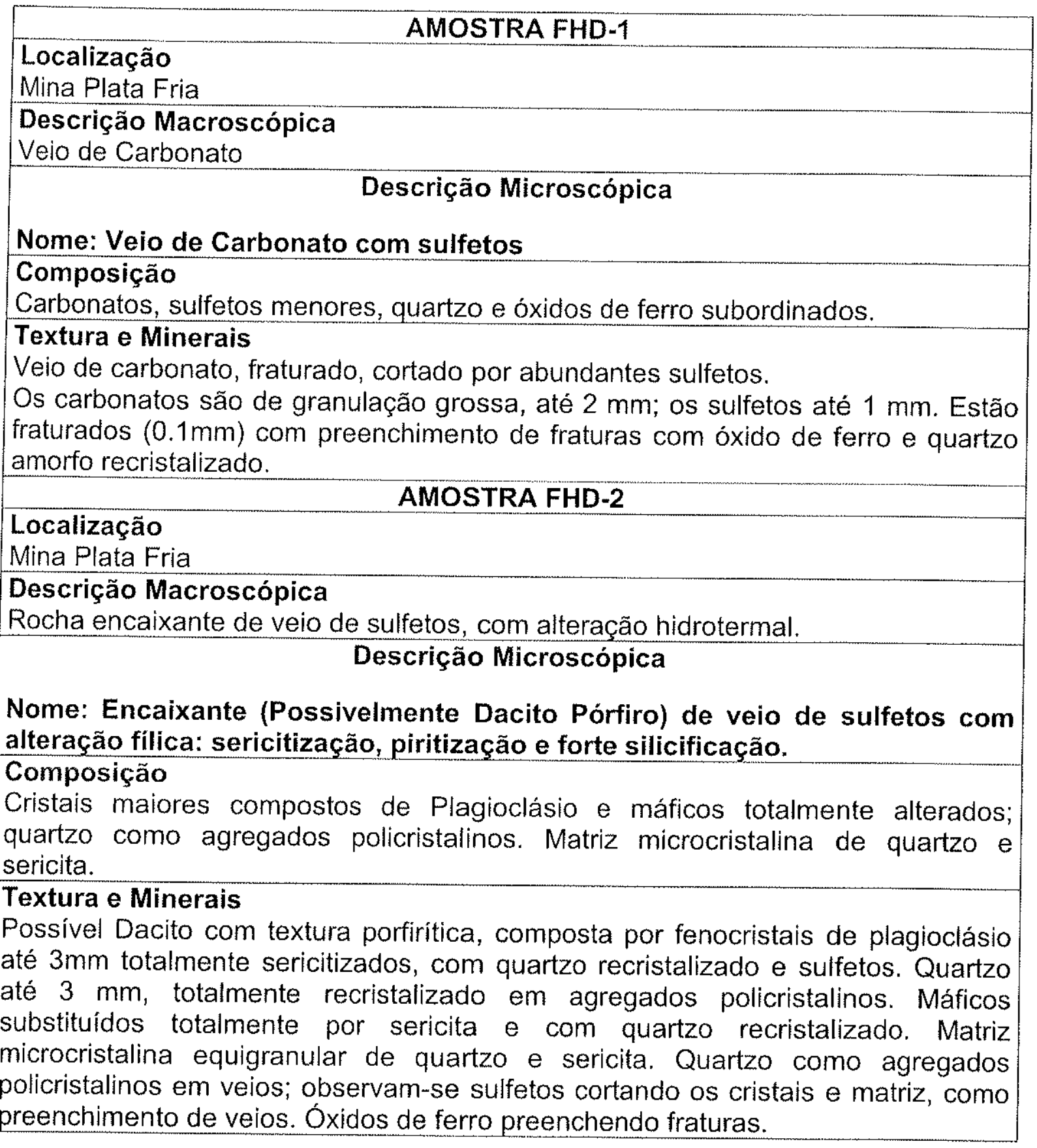




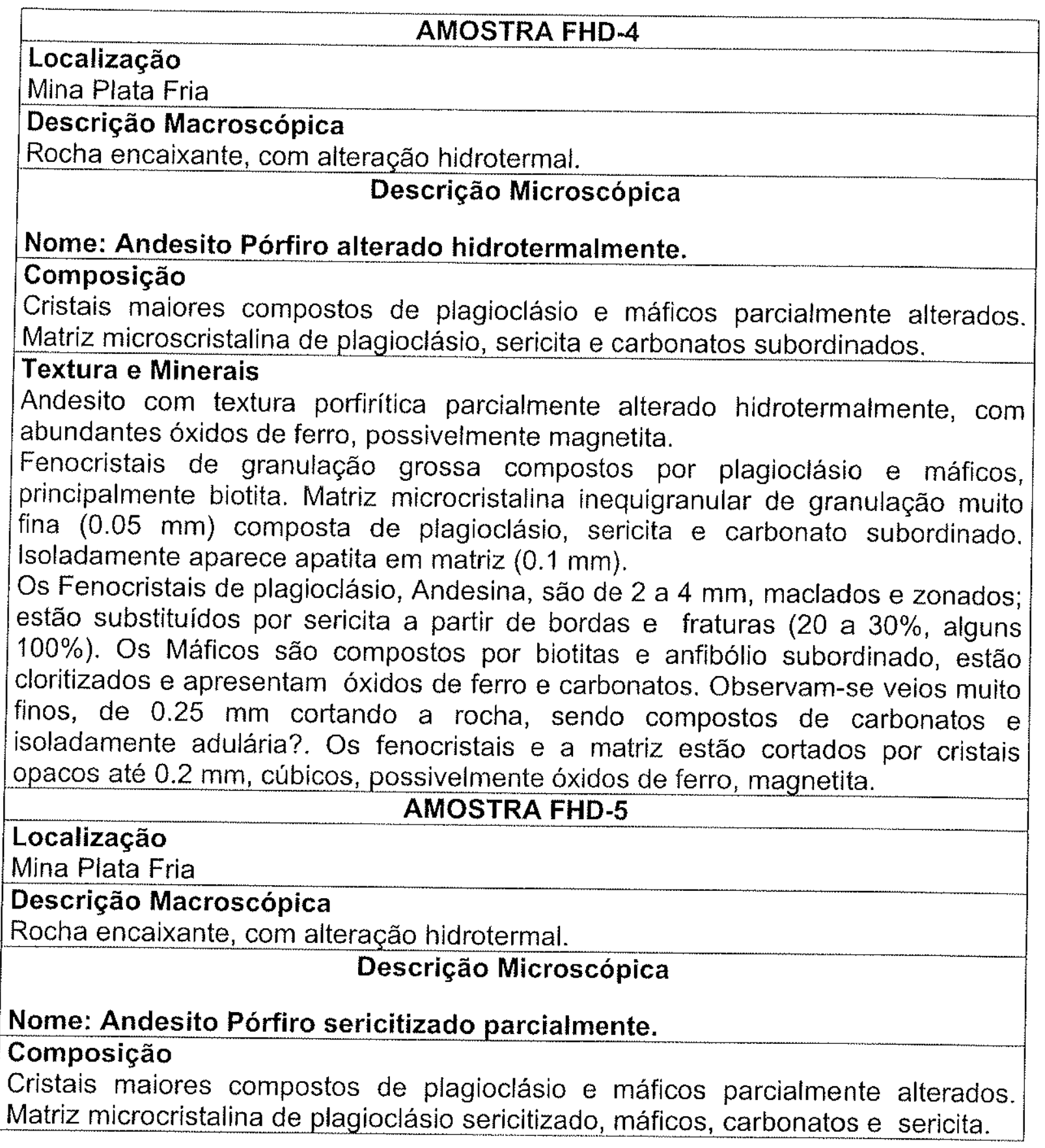




\section{Textura e Minerais}

Andesito com textura porfirítica parcialmente alterado hidrotermalmente, com óxidos de ferro, possivelmente magnetita.

Fenocristais de granulação grossa compostos por plagioclásio e máficos. Matriz microcristalina inequigranular de granulação muito fina $(0.01 \mathrm{~mm})$ composta de plagioclásio sericitizado, sericita, carbonato e isoladamente apatita e epidoto $(0.1$ $\mathrm{mm})$.

Os Fenocristais de plagioclásio, Andesina, são de 2 a $4 \mathrm{~mm}$, maclados e zonados; estão substituidos por sericita a partir de bordas e fraturas (20 a $30 \%$, alguns $100 \%$ ), isolados zircão e epidoto dentro de plagioclásio. Os Máficos são compostos por biotitas e anfibólios fortemente cloritizados e substituidos por carbonatos e óxidos de ferro; ocorrem carbonatos até $0.6 \mathrm{~mm}$ em matriz e nos cristais. Os fenocristais e a matriz estão cortados por cristais opacos de até 0.1 $\mathrm{mm}$, cúbicos, possivelmente óxidos de ferro, magnetita. Observa-se óxidos de ferro como preenchimento de fraturas.

\section{Localização}

AMOSTRA FHD-7

Mina La Palma

Descrição Macroscópica

Veio de sulfetos dentro de encaixante alterado.

\section{Descrição Microscópica}

Nome: Veio de sulfetos dentro de encaixante com silicificação.

\section{Composição}

Quartzo, sericita e clorita subordinada.

\section{Textura e Minerais}

Veio de sulfetos e quartzo.

Quartzo em camadas, formadas por agregados de quartzo euédrico recristalizado com tamanhos finos, até $1 \mathrm{~mm}$. Alternam agregados de quartzo até $0.025 \mathrm{~mm} \mathrm{com}$ menor sericita. Ocorrem sericita e clorita acicular isolada acompanhando o quartzo.

\section{Localização}

Mina La Palma

\section{Descrição Macroscópica}

Rocha (Encaixante) alterada hidrotermalmente.

\section{Descrição Microscópica}

Nome: Dacito Pórfiro fortemente alterado hidrotermalmente, sericitizado. Composição

Fenocristais de Plagioclásio, quartzo e máficos, fortemente alterados. Matriz microcristalina de quartzo, sericita, carbonatos. 


\section{Textura e Minerais}

Dacito com textura porfiritica fortemente alterado hidrotermalmente. Os fenocristais são de plagioclásio, quartzo e máficos alterados. Matriz microcristalina equigranular muito fina $0.0125 \mathrm{~mm}$, composta de quartzo, sericita, carbonatos.

O Plagioclásio é de granulação grossa, 2 até $4 \mathrm{~mm}$, substituído (80 a $90 \%$ ) por sericita e carbonatos. O quartzo tem tamanho entre 1 a $2 \mathrm{~mm}$, arredondado e com golfos, levemente fraturado e com deslocamento. Os máficos são de 1 até $3 \mathrm{~mm}$, as micas estão substituídas por clorita, carbonatos, sericita e óxidos de ferro; os anfibólios estão substituídos por clorita, carbonato, sericita e óxidos de ferro. Carbonatos ocorrem na matriz, com tamanhos até $0.6 \mathrm{~mm}$, raros óxidos e possivelmente pirita.

\section{Localização}

AMOSTRA FHD-15

Mina La Mona

Descrição Macroscópica

Rocha (Encaixante) alterada hidrotermalmente.

\section{Descrição Microscópica}

Nome: Dacito Pórfiro alterado hidrotermalmente, sericitizado.

\section{Composição}

Fenocristais de plagioclásio, quartzo e máficos; alterados. Matriz microcristalina de quartzo, sericita.

\section{Textura e Minerais}

Dacito com textura porfirítica alterado hidrotermalmente. Os fenocristais são de plagioclásio, quartzo e máficos alterados. Matriz microcristalina equigranular composta de quartzo e sericita.

Os Plagioclásios são de granulação grossa, 1 até $4 \mathrm{~mm}$ estão substituídos por sericita até $50 \%$, alguns $100 \%$. O quartzo possui tamanhos entre 1 e $3 \mathrm{~mm}$, alguns até $4 \mathrm{~mm}$, subédrico, com golfos; alguns apresentam recristalização de quartzos nas bordas e fraturas. Os máficos são micas e anfiboles, de tamanhos finos $1 \mathrm{~mm}$, e estão completamente cloritizados e sericitizados em menor proporção. Isolados sulfetos de $0.2 \mathrm{~mm}$.

\section{Localização}

AMOSTRA FHD-17

Mina Villonza

\section{Descrição Macroscópica}

Pórfiro (Encaixante) alterado hidrotermalmente.

\section{Descrição Microscópica}

Nome: Dacito Pórfiro alterado hidrotermalmente, sericitizado e com sulfetos disseminados.

Composição

Fenocristais de plagioclásio, quartzo e máficos; alterados. Matriz microcristalina de quartzo, sericita, clorita. 


\section{Textura e Minerais}

Dacito, com textura porfirítica alterado hidrotermalmente. Os fenocristais são de plagioclásio, quartzo e máficos, alterados. Matriz microcristalina inequigranular $(0.025 \mathrm{~mm})$ composta de quartzo, sericita e clorita.

Os plagioclásios são de granulação grossa 2 até $4 \mathrm{~mm}$, estão substituídos por sericita até $80 \%$, alguns até $100 \%$. Os quartzos são até $3 \mathrm{~mm}$, arredondados e com golfos, fraturados, com quartzo recristalizado nas bordas e fraturas. Máficos, geralmente cloritizados. Veio fino, $0.1 \mathrm{~mm}$, de quartzo microcristalino cortando a rocha. Sulfetos disseminados, tamanho até $0.5 \mathrm{~mm}$.

\section{Localização}

AMOSTRA FHD-18

Marmato Bajo, Nivel 1260, Encaixante veio 2.

Descrição Macroscópica

Pórfiro (Encaixante) alterado hidrotermalmente.

\section{Descrição Microscópica}

Nome: Dacito Pórfiro alterado hidrotermalmente, sericitizado e piritizado (Fílica).

\section{Composição}

Fenocristais de plagioclásio, quartzo e máficos, alterados. Matriz microcristalina de quartzo, sericita, clorita.

\section{Textura e Minerais}

Dacito, com textura porfirítica alterado hidrotermalmente. Os fenocristais são de plagioclásio, quartzo e máficos, alterados. Matriz microcristalina inequigranular composta de quartzo, sericita e clorita, rara apatita.

Os Plagioclásios de tamanhos de 1 até $3 \mathrm{~mm}$, estão substituídos por sericita entre 90 a $100 \%$ e isoladamente carbonatos. Os quartzos, com tamanhos de 1 até 4 $\mathrm{mm}$, são subédricos, fraturados com preenchimento de sericita e isoladamente carbonatos. Máficos compostos de micas e anfibólios, substituídos por clorita, e subordinadamente carbonato e sericita. Fraturas de até $0.25 \mathrm{~mm}$ com preenchimento de óxidos de ferro, cortamdo a rocha. Sulfetos disseminados. raros cristais de apatitas de $0.05 \mathrm{~mm}$ em quartzo.

\section{Localização}

AMOSTRA FHD-19

Marmato Bajo, Nivel 1260, veio 2.

Descrição Macroscópica

Veio com sulfetos.

\section{Descrição Microscópica}

Nome: Veio de Carbonatos com sulfetos.

\section{Composição}

Carbonatos, sulfetos, sericita, argila.

Textura e Minerais

Veio de carbonatos anédricos e sulfetos, com sericita em agregados muito finos. 


\section{Localização}

AMOSTRA FHD-20

Marmato Bajo, Nivel 1260, Encaixante, 10 metros do veio 2.

Descrição Macroscópica

Pórfiro (Encaixante) alterado hidrotermalmente.

\section{Descrição Microscópica}

Nome: Dacito Pórfiro alterado hidrotermalmente, propilitizado.

Composição

Fenocristais de plagioclásio, quartzo e máficos; alterados. Matriz microcristalina de quartzo, plagioclásio, sericita, carbonato, epidoto.

\section{Textura e Minerais}

Dacito, com textura porfiritica alterado hidrotermalmente, propilitizado. Os fenocristais são de plagioclásio, quartzo e máficos, alterados. Matriz microcristalina equigranular composta de quartzo, plagioclásio sericitizado, carbonato e epidoto.

Os Plagioclásios, andesina, entre 2 a $3 \mathrm{~mm}$, estão zonados e maclados e substituídos por sericita desde as bordas e fraturas, entre 20 a $30 \%$, alguns $50 \%$; também estão substituidos por epidoto e carbonato subordinados. Os quartzos com tamanhos de 1 até $5 \mathrm{~mm}$, são subédricos com golfos, levemente fraturados com preenchimento de material de matriz. Máficos compostos de anfibólio e micas alterados para clorita e substituídos por epidoto e carbonatos. Epidoto como agregados substituindo os máficos, pode estar relacionado a fraturas. Sulfetos e óxidos em matriz e fenocristais.

Localização

AMOSTRA FHD-24

Marmato Bajo, Nivel 1160, Encaixante.

Descrição Macroscópica

Pórfiro (Encaixante) afetado por alteração hidrotermal.

\section{Descrição Microscópica}

Nome: Dacito Pórfiro alterado hidrotermalmente, propilitizado e sericitizado. Composição

Fenocristais de plagioclásio, quartzo e máficos; alterados. Matriz microcristalina de quartzo, plagioclásio, sericita, carbonato, rara apatita.

\section{Textura e Minerais}

Dacito com textura porfirítica alterado hidrotermalmente, propilitizado e sericitizado. Os fenocristais são de plagioclásio, quartzo e máficos alterados. Matriz microcristalina equigranular composta de quartzo, sericita, carbonato e epidoto, apatitas subordinada.

Os Plagioclásios são de tamanho de 3 a $5 \mathrm{~mm}$, estão completamente alterados e substituídos por sericita, epidoto, e subordinadamente carbonato. Os quartzos são subédricos com golfos. Máficos compostos de anfibólio e micas, alterados a clorita e localmente substituidos por sericita, carbonatos, epidoto, óxidos de ferro. Epidoto como agregados. Sulfetos em matriz e fenocristais. 
Localização

AMOSTRA FHD-26

Marmato Bajo, Nivel 1160 , Brecha.

Descrição Macroscópica

Brecha.

\section{Descrição Mícroscópica}

Nome: Brecha Hidrotermal composta de carbonato com fragmentos de encaixante alterado hidrotermalmente.

\section{Composição}

Carbonato, fragmentos de Dacito Pórfiro sericitizado compostos de: Plagioclásio sericitizado, quartzo e máficos cloritizados.

\section{Textura e Minerais}

Veio de carbonato com fragmentos de encaixante alterada hidrotermalmente.

Os carbonatos são de tamanhos de 3 a $5 \mathrm{~mm}$. Os fragmentos correspondem a um Dacito Pórfiro, constituídos por plagioclásio fortemente sericitizado, quartzo subédrico fraturado e máficos cloritizados, dentro de matriz de quartzo, plagioclásio e sericita. Sulfetos nos fragmentos do pórfiro. Oxidos presentes.

\section{Localização}

AMOSTRA FHD-27

Marmato Bajo, Nivel 1160, Brecha.

Descrição Macroscópica

Brecha.

\section{Descrição Microscópica}

Nome: Brecha Hidrotermal composta de carbonato com fragmentos de encaixante alterada hidrotermalmente.

Composição

Carbonato, fragmentos de Dacito Pórfiro sericitizado compostos de: Plagioclásio sericitizado, quartzo e máficos cloritizados.

\section{Textura e Minerais}

Veio de carbonato com fragmentos de encaixante alterado hidrotermalmente.

Os carbonatos são de tamanhos de 1 a $3 \mathrm{~mm}$, euédricos, com sulfetos dentro de carbonato. Os fragmentos correspondem a um Dacito Pórfiro, composto por fenocristais de quartzo, plagioclásio sericitizado, máficos completamente cloritizados e localmente sericitizados, dentro de matriz equigranular, composta de quartzo e sericita. Fraturas nos quartzos com preenchimento de quartzo microcristalino. 


\section{Localização}

Marmato Bajo, Nivel 1160, Encaixante.

Descrição Macroscópica

Pórfiro (Encaixante) afetado por alteração hidrotermal.

\section{Descrição Microscópica}

Nome: Dacito Pórfiro levemente alterado hidrotermalmente.

Composição

Fenocristais de plagioclásio, quartzo e máficos; levemente alterados. Matriz microcristalina de quartzo, plagioclásio, sericita.

\section{Textura e Minerais}

Dacito, com textura porfiritica alterado hidrotermalmente, e com sulfetos disseminados.

Os fenocristais são de plagioclásio, quartzo e máficos, alterados. Matriz microcristalina equigranular composta principalmente de quartzo, e subordinadamente plagioclásio e sericita. Os fenocristais de quartzo são em geral de tamanhos entre 1 a $3 \mathrm{~mm}$, alguns $5 \mathrm{~mm}$, subédricos, com golfos, levemente fraturados. Os plagioclásios estão fraturados e levemente substituidos por sericita $(10 \%)$. Os máficos são anfibólio e micas alterados para clorita e localmente substituídos por epidoto e também óxidos de ferro. Sullfetos em matriz e fenocristais, associados a óxidos. 


\section{DESCRIÇÕES DAS AMOSTRAS DAS ENCAIXANTES}

\begin{tabular}{|c|c|c|}
\hline AMOSTRA & DESCRIÇÃO & AUTOR \\
\hline FHD-6 & $\begin{array}{l}\text { Xisto Grafitoso. Alternam laminas de grafita fortemente } \\
\text { dobradas com lâminas milimétricas de quartzo policristalino. }\end{array}$ & $\mathrm{FHD}$ \\
\hline CJ-01 & $\begin{array}{l}\text { Pórfiro Latítico. Matriz/Porf, 50/50: Matriz de quartzo e } \\
\text { plagioclásio. Fenocristais: } 70 \% \text { Plagioclásio (Oligoclásio), } \\
\text { Quartzo 5\%, >>Biotitas, Opacos na matriz, >>Hornblenda?, } \\
>>\text { Titanita?; clorita por alteração de Hornblenda, sericita e } \\
\text { carbonatos por leve alteração de plagioclásio nas fraturas. }\end{array}$ & CJV \\
\hline CJ-02 & $\begin{array}{l}\text { Piroxenito. Textura granular equidimensional. } 40 \% \text { Olivina, } 30 \% \\
\text { Clinopiroxênio Augita?, } 10 \% \text { Tremolita, Talco?, >>Anfibolio. } \\
\text { Tremolita secundária, anfibólio proveniente de piroxênio, olivina } \\
\text { rodeada de serpentina. }\end{array}$ & CJV \\
\hline CJ-03 & $\begin{array}{l}\text { Quartzo-Biotita Xisto. } 40 \% \text { Biotita, Quartzo } 15 \% \text {, Plagioclásio } \\
15 \%, \text { Apatito, >Feldspato K, Moscovita } 20 \% \text {, Clorita. Rocha } \\
\text { xistosa laminada, intensamente microdobrada, veios mm; } \\
\text { alternância de bandas de quartzo, bandas sericíticas-biotiticas; } \\
\text { bandas micáceas; matriz de plagioclásio/quartzo. Biotita } \\
\text { alterada, cloritizada, seritizada, desferrizada. }\end{array}$ & CJV \\
\hline CJ -04 & $\begin{array}{l}\text { Xisto Anfibólico (Hornblenda Xisto). Hornblenda } 50 \% \text {, } \\
>\text { Plagioclásio?, Quartzo } 35 \% \text {, Titanita } 5 \% \text {, Granada e opacos } \\
10 \%,>\text { Biotita. Rocha foliada, textura de fluxo, milonitizada por } \\
\text { setores, quartzo parcialmente recristalizado. Anfibólios } \\
\text { cloritizados, plagioclásios argilizados. }\end{array}$ & CJV \\
\hline CJ-06 & $\begin{array}{l}\text { Xisto Anfibólico (Biotita-Sericita-Hornblenda Xisto). Hornblenda } \\
30 \% \text {, Biotita }+ \text { Sericita } 30 \% \text {, Quartzo } 30 \% \text {, Actinolita?, Opacos } \\
10 \%,>\text { Apatito, >>Titanita, > }>\text { Clorita. Rocha xistosa com } \\
\text { textura de fluxo, bandas de mica englobam agregados de } \\
\text { quartzo; bandas diferenciadas de anfibólio e micas, bandas de } \\
\text { antibolio, bandas de biotita + sericita + quartzo. Biotita } \\
\text { cloritizada. }\end{array}$ & CJV \\
\hline CJ-66A & $\begin{array}{l}\text { Pórfiro Dacítico. Plagioclásio } 60 \% \text {, Quartzo } 20 \% \text {, Biotita } 20 \% \text {. } \\
\text { Clorita secundária, plagioclásio com sericitização nas fraturas. }\end{array}$ & CJV \\
\hline IGM-6921 & $\begin{array}{l}\text { Microquartzodiorito Porfiritico. Plagioclásio } 36.4 \% \text {, Hornblenda } \\
9.8 \% \text {, Biotita } 2.6 \% \text {. Matriz: Quartzo } 12.6 \% \text {, Plagioclásio } 36 \% \text {, } \\
\text { opacos } 0.1 \% \text {, Magnetita } 0.6 \% \text {, clorita biotíta } 1.3 \% \text {. Opacos em } \\
\text { matriz e fenocristais. Máficos cloritizados, sericita muito isolada } \\
\text { em matriz e plagioclásio. }\end{array}$ & IGM \\
\hline IGM-119089 & $\begin{array}{l}\text { Basalto. Fenocristais de Plagioclásio (andesina), matriz de } \\
\text { plagioclásio, subordinadamente clorita, augita?, palagonita?. } \\
\text { Opacos abundantes. }\end{array}$ & IGM \\
\hline IGM-8763 & $\begin{array}{l}\text { Diorito Horbléndico (Gabro). Plagioclásio } 62 \% \text {, Hornblenda } \\
35 \% \text {, Opacos } 2 \% \text {, Biotita 1\%, apatita, titanita subordinadas. } \\
\text { Opacos em máficos, menor em plagioclásio. Máficos } \\
\text { cloritizados. }\end{array}$ & IGM \\
\hline IGM-6912 & $\begin{array}{l}\text { Dunito Serpentinizado. Talco } 35 \% \text {, Antigorita } 55 \% \text {, Olivina } 6 \% \text {, } \\
\text { Cromita } 4 \%\end{array}$ & IGM \\
\hline \multicolumn{3}{|c|}{$\begin{array}{l}\text { Descrições segundo os autores abaixo: } \\
\text { IGM: INGEOMINAS } \\
\text { CJV: Cesar Javier Vinasco (Vinasco, 2001) } \\
\text { FHD: Fabio Humberto Díaz Pinzón }\end{array}$} \\
\hline
\end{tabular}

